WÂNIA MENDES SEIXAS

\title{
Memória fotográfica de Santos pelas lentes de José Dias Herrera
}

Dissertação apresentada ao Programa de Pós-Graduação em Ciências da Comunicação, Área de Concentração Teoria e Pesquisa em Comunicação, da Escola de Comunicações e Artes da Universidade de São Paulo, como exigência parcial para a obtenção do título de Mestre em Comunicação.

Orientador: Prof. Dr. Boris Kossoy 
Seixas, Wânia Mendes

Memória fotográfica de Santos pelas lentes de José Dias Herrera / Wânia Mendes Seixas - São Paulo : W.M. Seixas, 2008.

265 p. + anexos.

Dissertação (Mestrado) - Departamento de Jornalismo e Editoração / Escola de Comunicações e Artes/USP, 30/01/2008. Orientador: Prof. Dr. Boris Kossoy.

Bibliografia

1.Fotografia 2. História - Santos 3. Fotojornalismo 4. José Dias Herrera

CDD 21.ed. - 770 
BANCA EXAMINADORA 
Aos meus filhos Rolf Jr., Yuri e Igor, razão da minha existência e companheiros de jornada. 


\section{AGRADECIMENTOS}

Aos meus filhos, pela compreensão a tantos momentos de ausência;

À jornalista e amiga Maria Fernanda Azevedo Marques, pelo apoio incondicional, em especial, nos momentos mais difíceis;

Ao pesquisador e amigo Paulo Monteiro, pelo auxílio durante as pesquisas históricas;

Ao colecionador e escritor Laire José Giraud, pelo compartilhar dos muitos documentos e informações,

À Lara Lobo, da Fundação Arquivo e Memória de Santos, pela atenção e prontoatendimento;

À Maria Luiza Tucci Carneiro e Dulcília Helena Schroeder Buitoni, pelas sugestões e carinho;

À Wilma Therezinha Fernandes Andrade, pelo estímulo e primeira leitura desse trabalho;

A Boris Kossoy, pela paciente orientação e direcionamento;

E aos meus pais Flor e Walter (in memorian), que seguraram a minha mão e me incentivaram no início dessa caminhada. 
"Fotografia é memória e com ela se confunde. Fonte inesgotável de informação e emoção. Memória visual do mundo físico e natural, da vida individual e social. Registro que cristaliza, enquanto dura, a imagem escolhida e refletida - de uma ínfima porção de espaço do mundo exterior. É também a paralisação súbita do incontestável avanço dos ponteiros do relógio: é pois, o documento que retém a imagem fugidia de um instante da vida que flui ininterruptamente." 


\section{RESUMO}

O propósito principal desta dissertação é realizar uma primeira análise da vida e da obra do fotógrafo santista José Dias Herrera, considerando a sua relevância como profissional no contexto da história da fotografia no Brasil, assim como o valor documental da sua obra para a história de Santos. Nosso estudo procura abarcar o período que vai de 1937, quando Herrera iniciou sua carreira como fotógrafo, até os dias de hoje. Do seu enorme acervo, foram selecionadas imagens que documentam as transformações da paisagem e dos hábitos urbanos de Santos, a presença de personalidades de projeção nacional e internacional, bem como, os grandes dramas políticos que afetaram o País, ao longo do tempo. É nossa esperança que este trabalho venha contribuir para a memória da cidade de Santos através da fotografia.

PALAVRAS-CHAVE: fotografia, memória, Santos, fotojornalismo. 


\begin{abstract}
This paper aims at carrying out a first analysis of the life and work of a santista photographer called José Dias Herrera, taking into account his importance as a professional in Brazil historical context, as well as the contribution of his work to the history of Santos. This research tried to cover the period from 1937, when Herrera initiated his career as a photographer, until today. From his collection it was selected the images that show the transformation in the scenery and in the urban habits of Santos, personalities nationally or internationally famous as well as huge political dramas that has affected the country through the years. We hope that this paper will contribute to the memory of Santos through photograph.
\end{abstract}

KEY-WORDS: photograph, memory, Santos, photojournalism 


\section{SUMÁRIO}

INTRODUÇÃO

CAPÍTULO 1 - Breve perfil da cidade de Santos

1.1) O Porto do café 23

1.2) A transformação da paisagem urbana $\quad 31$

1.3) A intervenção militar 38

CAPÍTULO 2 - José Dias Herrera, o fotógrafo de Santos 45

2.1) Os pioneiros da fotografia 46

2.2) O nascimento de um fotógrafo $\quad 51$

2.3) José Dias Herrera e o fotojornalismo 57

2.4) A experiência como radialista e o cotidiano durante a $2^{\text {a }}$ Guerra Mundial 62

$\begin{array}{ll}\text { 2.5) O fotógrafo das elites e do povo } & 67\end{array}$

2.6) O trabalho de Herrera em A Tribuna e os anos de chumbo 70

$\begin{array}{ll}\text { 2.7) O fotógrafo de ontem e hoje } & 77\end{array}$

2.8) A família e as recompensas da profissão $\quad \mathbf{8 0}$

2.9) Herrera, memória viva da cidade de Santos 82

CAPÍTULO 3 - Santos, uma história em imagens $\quad 87$

$\begin{array}{ll}\text { 3.1) Urbanismo } & 88\end{array}$

3.2) Patrimônios da arquitetura santista 119

3.3) Social e Política 145

$\begin{array}{ll}\text { 3.4) Transportes e Serviços } & 174\end{array}$ 


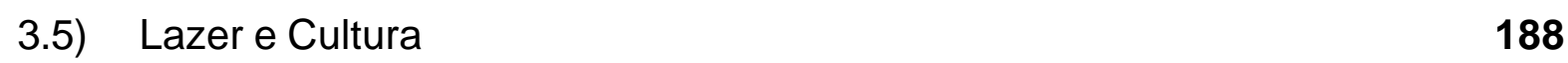

$\begin{array}{lr}\text { 3.6) Carnaval } & \mathbf{2 1 0}\end{array}$

$\begin{array}{ll}3.7) & \text { Porto } \\ & 225\end{array}$

3.8) Pelé e o Santos Futebol Clube 243

CONSIDERAÇÕES FINAIS 253

REFERÊNCIAS BIBLIOGRÁFICAS $\quad 259$

\section{ANEXOS}




\section{INTRODUÇÃO}

\section{Objetivo}

O objetivo desse trabalho é realizar uma análise detalhada da história de vida e da atividade profissional do fotógrafo santista José Dias Herrera, considerando a sua relevância no contexto da história da fotorreportagem no Brasil e também pelo valor documental de sua obra para a história da cidade de Santos.

Aos 87 anos de idade, José Dias Herrera é um dos mais antigos fotógrafos em atividade no Brasil. Iniciou sua carreira profissional como repórter fotográfico, em 1937, no jornal O Diário de Santos (da cadeia Diários Associados). Herrera também exerceu sua profissão no jornal $A$ Tribuna e na Prefeitura de Santos, onde trabalha até hoje, na Secretaria de Comunicação Social (Secom). O fotógrafo ainda produziu material para a Folha de São Paulo, O Esporte e para a histórica revista O Cruzeiro.

No decorrer de sua atuação profissional, constituiu uma verdadeira memória visual da cidade de Santos; uma memória que precisa ser resgatada e divulgada junto ao público, de forma a enriquecer o patrimônio cultural da cidade e a história do fotojornalismo no Brasil. O acervo do fotógrafo conta com cerca de um milhão de imagens capturadas ao longo dos últimos 70 anos de vida política, cultural, administrativa e esportiva da cidade de Santos.

\section{Objeto}

A inauguração da Via Anchieta e da COSIPA, em Cubatão, a explosão do gasômetro, visitas de políticos, presidentes e personalidades estrangeiras a Santos, 
o desenvolvimento da cidade e o cotidiano de seus habitantes, tudo foi captado pelas lentes de Herrera. Trabalhando no jornal $A$ Tribuna, a partir de 1953, o repórter-fotográfico ajudou a construir o mito Pelé, acompanhando a ascensão do craque no Santos Futebol Clube (SFC). A primeira foto de Pelé, como jogador estreante, na Vila Belmiro, foi feita por Herrera, que também registrou toda a carreira do jogador no mencionado clube e a fase de ouro do futebol santista, acompanhando o time por vários países do mundo. Em 2002, o Museu de Arte de São Paulo (MASP) montou a exposição "Pelé, a arte do Rei", que incluía diversas fotos de Herrera e que depois excursionou por várias capitais brasileiras. Foi a primeira exposição que reconhecia explicitamente a participação de Herrera na construção do mito do "Rei".

O estudo da vida e da obra do fotógrafo José Dias Herrera considera o valor documental do conjunto da sua obra no que se refere à linguagem específica do fotojornalismo ou da fotorreportagem, área de atuação precípua do fotógrafo. Antes de mais nada, temos que refletir sobre os condicionamentos históricos e contextuais que codificam o olhar fotográfico de José Dias Herrera. O início de sua carreira se insere justamente num momento - final da década de 1930 e início da década de 1940 - em que se generaliza o uso jornalístico, comercial, publicitário e editorial da imagem fotográfica. Como analisa Boris Kossoy: "A partir dos anos de 1940, intensificou-se o uso indiscriminado de imagens enquanto ilustrações dos mais variados temas: natureza, cidades, transportes, turismo, indústria, comércio, moda, miséria e conflitos sociais". ${ }^{1}$

No Brasil, uma das referências mais importantes do fotojornalismo é a revista $O$ Cruzeiro, fundada em 1928 por Assis Chateaubriand, proprietário dos Diários

\footnotetext{
${ }^{1}$ KOSSOY, Boris. Os tempos da Fotografia: o efêmero e o perpétuo. 2007, p.140.
} 
Associados. A revista se inspirava no modelo internacional (sua fonte de inspiração mais direta era a revista americana Life) e inaugurou no país uma nova forma de fazer jornalismo aliando reportagem e imagem. O fotógrafo passa a ser visto como "testemunha ocular" no sentido em que a imagem fotográfica elabora uma narrativa sobre os fatos. As mudanças impostas pelo periódico $O$ Cruzeiro acabaram impulsionando a modernização da estética de outros periódicos e essas transformações não tardariam a influenciar a mídia impressa nas principais cidades brasileiras, entre elas, a cidade de Santos.

Tais mudanças logo se refletiram na reestruturação dos dois jornais mais importantes de Santos na primeira metade do século XX: os concorrentes O Diário de Santos e A Tribuna, nos quais Herrera trabalhou e onde aprendeu o ofício de fotojornalista. Mas, evidentemente, numa cidade de importância econômica, política e estratégica como Santos, Herrera não foi o primeiro fotógrafo a registrar suas transformações. A cidade, dsede o século XIX, presenciava a atuação de fotógrafos renomados como Militão Augusto de Azevedo, José Marques Pereira, Sophia Pretzel, que voltaram suas lentes para a cidade portuária, pela qual passava toda a riqueza produzida pelo café.

\section{Justificativa}

Este trabalho pretende contribuir para o reconhecimento público do trabalho incansável de um homem que, além de ser "memória viva" de uma época e de uma cidade, ainda tem muito a dizer às novas gerações. Poder conhecer a vida e a obra de um fotógrafo como José Dias Herrera, mais que uma oportunidade, é um privilégio para o pesquisador. 
Esta é a primeira investigação sistemática sobre a obra fotográfica de Herrera e esperamos que venha recuperar a trajetória pessoal e profissional do fotógrafo, contribuir para a valorização de sua obra e de sua memória e enriquecer a história de Santos. Acreditamos também que a nossa pesquisa possa contribuir para a bibliografia fotográfica brasileira e resgatar um dos mais importantes fotógrafos santistas, revelando o seu trabalho, até agora pouco divulgado, ao grande público.

Vale aqui destacar que, nos últimos anos, a pesquisa na área de fotografia brasileira vem crescendo substancialmente. Expande-se cada vez mais a reflexão sobre a fotografia como fonte de pesquisa ou documento.

\section{Procedimentos Metodológicos}

Para o estudo da obra de Herrera, é fundamental considerarmos a finalidade de sua produção, essencialmente realizada no contexto da imprensa diária ao longo das décadas de atuação. Sob o ponto de vista da análise iconográfica, selecionamos e analisamos a transformação da paisagem urbana, as reformas e melhoramentos na cidade, a modificação dos hábitos cotidianos com a generalização do costume de freqüentar a praia, a presença em Santos de grandes personalidades de projeção nacional e internacional, os grandes dramas políticos que afetaram o país, entre outros temas. $\mathrm{Na}$ análise das fotografias, objeto desta pesquisa, procuramos resgatar os elementos que marcaram a história da cidade de Santos, em contraponto com os aspectos particulares da vida do fotógrafo e sua visão dos eventos que documentou. A baliza temporal vai de 1937 (ano que o fotógrafo iniciou a sua carreira) até os dias atuais, visto que Herrera continua ativo na profissão. 
Durante o trabalho, numa primeira etapa, procedemos a um diagnóstico do acervo do fotógrafo, em especial, ao lote de 20 mil imagens, atualmente sob a guarda da Fundação Arquivo e Memória de Santos (FAMS)². Consultamos também os acervos do Museu dos Cafés do Brasiß, da Secretaria de Comunicação Social de Santos $^{4}$ e particulares de Pelé, de Laire José Giraud ${ }^{5}$ e do próprio fotógrafo ${ }^{6}$. Num de seus depoimentos, o fotógrafo mostra surpresa à importância dada a seu acervo:

Nunca imaginei que produziria tanta coisa e que dariam tanta importância ao meu trabalho. Por isso, não tive a preocupação de organizar o acervo. Existem imagens que não sei a data e nem direito o que são. Quando me pedem imagens sobre algum assunto ou época específica, preciso de um tempo para encontrar (...) me arrependo muito de não ter organizado. Talvez, não tivesse tanto trabalho para encontrar as coisas que me pedem. Paciência! ${ }^{7}$

O trabalho com as fontes primárias contou com a utilização de uma ficha iconográfica ${ }^{8}$ que contém informações como: descrição geral, aspectos específicos, data, local, dados sobre a produção e a publicação, técnicas utilizadas etc. Em seguida, selecionamos as imagens segundo temas, recuperando a sua organização original, considerando que, grande parte do acervo está vinculado à mídia impressa.

\footnotetext{
${ }^{2}$ A Fundação Arquivo e Memória de Santos é uma instituição que trabalha com o gerenciamento dos arquivos públicos municipais e com a memória documental e iconográfica da cidade de Santos, garantindo a salvaguarda, a preservação e a disseminação desse patrimônio. Em 2003, ao acervo fotográfico da FAMS, que contava com cerca de oito mil imagens antigas, foi incorporada uma coleção de 20 mil negativos - flexíveis, em chapa e de vidro - de Herrera, que hoje se encontram em processo de identificação, higienização e catalogação.

${ }^{3}$ Museu que resgata a memória do comércio cafeeiro da Cidade de Santos a partir do século XIX.

${ }^{4}$ Órgão responsável pela organização e execução dos serviços de informação sobre as atividades da Prefeitura Municipal, onde Herrera trabalha desde 1987.

${ }^{5}$ Despachante aduaneiro, colecionador de cartões-postais antigos de Santos e publicou cinco livros, como autor e co-autor, sobre temas da Santos antiga.

${ }^{6} \mathrm{O}$ fotógrafo possui em sua residência cerca de 300 mil negativos "guardados" em armários e gavetas, sem identificação e sem obedecer a nenhuma ordem (data, assunto, lugar) de arquivamento.

Depoimento do fotógrafo. 07/03/2005.

${ }^{8}$ Modelo em anexo.
} 
Alguns exemplos de temas são: Pelé, personalidades, transformações urbanas em Santos, o futebol, moda, transporte, entre outros.

$\mathrm{Na}$ imprensa, realizamos pesquisas nos jornais $A$ Tribuna, O Diário e na revista O Cruzeiro, analisando o trabalho do fotógrafo nesses periódicos. Além disso, utilizamos uma bibliografia complementar com o objetivo de inserir o trabalho do fotógrafo no contexto mais amplo da história da fotografia e do fotojornalismo no Brasil. Finalmente, foram de suma importância os depoimentos concedidos pelo fotógrafo para esta pesquisa. Eles constituem a alma das análises das imagens. Entrevistas com parentes e demais personalidades contribuíram para darmos corpo a esta pesquisa.

\section{Referencial teórico}

A metodologia empregada no encaminhamento da pesquisa se baseou, principalmente, no modelo de análise (técnico/iconográfico) e interpretação (dimensão cultural/ideológica) das fontes fotográficas proposto por Boris Kossoy. Primeiramente, elencamos seus elementos constitutivos (fotógrafo, assunto, tecnologia) e suas coordenadas de situação (espaço, tempo) numa tentativa de reconstrução do processo que originou a representação. Em seguida, um inventário analítico e o levantamento preciso dos elementos icônicos (conteúdo da imagem) completou a análise. Segundo Kossoy, "se a análise iconográfica situa-se no nível da imagem, a interpretação iconológica tem aí seu ponto de partida e estende-se além do documento visível, além da chamada evidência documental. Trata-se da 
recuperação de diferentes camadas de significação. A interpretação iconológica se desenvolve na esfera das idéias, das mentalidades". 9

Nesse ponto, foi de suma importância a compreensão dos conceitos de primeira e segunda realidades desenvolvidos por Kossoy. "A primeira realidade é o próprio passado (...) é a realidade do assunto em si, na dimensão da vida passada(...) A segunda realidade é a realidade do assunto representado, (...) a realidade fotográfica do documento." 10

Ainda com base em Kossoy, conseguimos durante a pesquisa estabelecer as necessárias distinções teóricas entre história da fotografia e história através da fotografia. Para a história da fotografia, é ela própria (a fotografia) o objeto da pesquisa e, nesse caso, interessam, fundamentalmente, a tecnologia empregada, os estilos e tendências vigentes no momento (tempo histórico) de sua gênese. Já para a história através da fotografia, importam as imagens pelo seu valor documental. "Trata-se da fotografia enquanto instrumento de pesquisa, prestando-se à descoberta, análise e interpretação da vida histórica". ${ }^{11}$ O livro Fotografia \& História, de Kossoy pode ser considerado uma verdadeira cartilha de "como fazer" a análise das imagens fotográficas mostrando passo-a-passo o caminho das pedras para o pesquisador e foi de extrema importância no desenvolvimento deste trabalho.

Contribuição importante, também deve ser creditada ao historiador inglês Peter Burke, que em seu livro Testemunha Ocular: História e Imagem faz um levantamento minucioso das oportunidades e desafios de se usar imagens para compreender outras épocas. Segundo ele, as imagens não devem ser consideradas simples reflexões de suas épocas e lugares, mas sim, extensões dos contextos sociais em que elas foram produzidas. No livro, ele disseca gravuras, pinturas, fotografias e

\footnotetext{
${ }_{9}^{9}$ KOSSOY, Boris. Os Tempos da Fotografia: o Efêmero e o Perpétuo. 2007, p 55 e 56.

${ }^{10}$ KOSSOY, Boris, Realidades e Ficções na Trama Fotográfica. 2002. p. 37.

${ }^{11}$ KOSSOY, Boris, Fotografia \& História. 2001, p. 55.
} 
filmes de várias épocas e países para demonstrar a importância da visualidade na construção da história dos povos. ${ }^{12}$ Testemunha Ocular vem ajudar na consolidação da ascensão das fontes visuais entre os historiadores engajados no modelo proposto pela chamada "nova história". ${ }^{13}$

Outros autores trouxeram importantes luzes para este rabalho. Náo posso deixar de citar Walter Benjamin ${ }^{14}$ e a sua visão de que a fotografia em sua essência trouxe uma nova forma de olhar, uma nova percepção, naquilo que ele chamou de "reprodutibilidade técnica" da fotografia. Segundo o filósofo frankfurtiano, o automatismo da técnica deu à fotografia a capacidade de estabelecer uma nova relação entre o olho, a imagem e a realidade representada.

Roland Barthes também foi preponderante para a pesquisa, através da abordagem que contempla dois campos de relação entre a fotografia e aquele que a contempla. No primeiro campo relacional, a fotografia desperta um interesse cultural - o studium, na qual se procura na imagem o testemunho histórico, a composição, a atualidade. No segundo é o punctum o elemento que salta da imagem e adere ao olhar do espectador. Em A Mensagem Fotográfica ${ }^{15}$, Barthes esclarece que a fotografia é regida por códigos culturais e históricos, o que não significa que não exista uma significância construída na e pela imagem. Por isso, a fotografia pode ser analisada tanto do ponto de vista estético, como uma arte visual, quanto como um documento que atesta uma realidade, como esclarece Barthes:"na fotografia jamais posso negar que a coisa esteve lá. Há dupla posição conjunta: de realidade e de

\footnotetext{
${ }_{12}^{12}$ BURKE, Peter, Testemunha Ocular: história e imagem. 2004, passim.

${ }^{13}$ A nova história proposta pela Escola dos Annales (movimento que se contrapunha ao paradigma da historiografia tradicional) abriu uma terceira via (multidisciplinar e abrangente) ao estudo da história.

${ }^{14}$ BENJAMIN, Walter. "A obra de arte na era da sua reprodutibilidade técnica" (1935/1936). In: Magia, Técnica, Arte e Política: ensaios sobre literatura e história da cultura - Obras Escolhidas, vol. I. São Paulo, Brasiliense, 1993.

${ }^{15}$ BARTHES, Roland, A mensagem fotográfica, O óbvio e o obtuso: Ensaios críticos III. Rio de Janeiro, Nova Fronteira, 1990, passim.
} 
passado. E já que essa coerção só existe para ela, devemos tê-la, por redução, como a própria essência, o noema da Fotografia. [...] O nome do noema da Fotografia será então: 'Isso foi' 16

Entre outros autores estudados durante este trabalho, também quero destacar Susan Sontag que, em um de seus ensaios sobre fotografia, ressalta seu papel testemunhal: "A fotografia fornece provas. Determinada coisa que ouvimos falar, mas que nos suscita dúvidas, parece-nos comprovada quando dela vemos uma fotografia". ${ }^{17}$ Nesse sentido, podemos considerar a fotografia como um documento material que tem a função de perpetuar lembranças do passado e também suscitar problemáticas presentes. A fotografia é um suporte para o ato de recordar da sociedade, tarefa imbuída do papel social de criar laços de identidade coletiva. A fotografia, como documento que confere materialidade à identidade coletiva, tem uma dimensão simbólica que estimula a lembrança sobre outros modos de viver e de compreender o mundo, que fala de permanência ou mudança de costumes sugerindo o intervalo entre diferentes momentos históricos, entre o presente e 0 passado.

\section{Estruturação dos capítulos}

A dissertação foi dividida em três capítulos, ordenados de forma a melhor situarmos a fotografia de Herrera com a época e o lugar em que foi produzida, ou seja, a cidade de Santos desde os anos de 1930 até o presente. O recorte específico é amplo, por isso, a análise será mais intensiva no período de atividade do fotógrafo que vai da década de 1940 a 1970, intervalo no qual ocorre a parte

\footnotetext{
${ }_{17}^{16}$ BARTHES, Roland, A Câmara Clara: nota sobre a fotografia, 1984, p. 115.

17 SONTAG, Susan, Ensaios sobre a fotografia, 1981, p. 5.
} 
mais significativa da produção de Herrera. Isso nos permitirá relacionar sua atuação com as transformações da cidade de Santos.

No capítulo 1, Breve perfil e história da cidade de Santos, pretendemos traçar um panorama da história da cidade a fim de contextualizar a obra de José Dias Herrera, bem como, as análises de imagens que serão efetuadas nos capítulos subseqüentes. O capítulo foi concebido na justa medida de se constituir em pano de fundo para compreender a atuação de Herrera. Foi enfatizado o período que vai da reforma urbanística da cidade no final do século XIX, até os planos atuais de revitalização. O capítulo foi dividido em tópicos que pretendem contemplar os seguintes aspectos: a transformação da paisagem urbana da cidade, a mudança dos fluxos de riqueza e das funções econômicas, a transformação dos costumes e do cotidiano com a generalização do hábito de ir à praia, a importância de Pelé, do futebol e do Santos Futebol Clube, as personalidades que tiveram alguma relação com a cidade, o papel de Santos na história política nacional e a revitalização da vida urbana na cidade.

No capítulo 2, José Dias Herrera, fotógrafo de Santos, procuramos delinear a história de vida e a trajetória profissional de Herrera, a partir dos depoimentos do próprio fotógrafo e daqueles que trabalharam e conviveram com ele, além de consultas a diversos jornais e revistas da época. De início, fizemos uma breve apreciação dos pioneiros da fotografia em Santos. A seguir, contemplamos o período que vai desde seus primeiros passos em fotografia, a partir de 1937, quando conseguiu seu primeiro emprego registrado no Diário de Santos, até 2007, data da última fotografia analisada. Após ter deixado A Tribuna, Herrera continuou ativo como fotógrafo, fazendo trabalhos para a Secretaria de Comunicação da Prefeitura de Santos e outros, particulares. Neste capítulo, mostraremos mais detidamente 
como o fotógrafo era um elemento essencial na "construção da notícia", na medida em que era o "maestro" da ação; nenhum evento ocorria antes de o fotógrafo chegar. Contudo, o fotógrafo de jornal deve procurar sempre produzir um "efeito de real", como se seu olhar captasse o evento puro, no próprio ato intransitivo de acontecer. E é só entendendo os códigos que regem o seu olhar de fotógrafo e condicionam a sua perspectiva sobre a realidade que poderemos compreender melhor as possibilidades de utilização de seu acervo e seu valor documental para a construção da memória histórica da cidade de Santos.

O terceiro e último capítulo, Santos, uma história em imagens, foi reservado para as análises iconográficas de imagens representativas dos diversos períodos e temas tratados no texto. Analisamos uma iconografia selecionada, dividida em oito categorias: Urbanismo, Arquitetura, Social e Política, Lazer e Cultura, Carnaval, Transportes e Serviços, Porto e Pelé e o Santos Futebol Clube. Para cada bloco temático, foram selecionadas entre duas e quatro imagens, das quais uma foi escolhida para ser analisada e comentada. 


\title{
CAPÍTULO 1
}

\section{Breve perfil e história da cidade de Santos}

\begin{abstract}
Estamos aqui há muito tempo. Consolidamos e fizemos existir o Brasil a partir desta ilha. Resistimos e sobrevivemos aos piratas e corsários de muitas épocas e tomamos seus canhões para nossa defesa. Muitas vezes, reconstruímos a cidade bombardeada. E ficamos. E enviamos braços e mentes para ajudar na fundação de São Paulo e Rio de Janeiro. À nossa maneira e recursos, lutamos ao lado dos revolucionários americanos e usamos orgulhosos barretes de liberdade na França de 200 anos atrás. Pregamos e construímos a independência desse país e, já no dia seguinte, nos inscrevemos entre os lutadores pela República. E fomos poetas, soldados, políticos e, mais que tudo, trabalhadores de um porto. E apoiamos os revolucionários russos e combatemos ao lado dos republicanos espanhóis. Declaramos guerra ao nazismo como havíamos libertado os escravos, antes, no Brasil. Como antes do continente instituíamos o dia de mobilizações do $1^{\circ}$ de maio, conscientes de nossa importância na construção da sociedade moderna. E, de escravos a políticos e combatentes livres de todos os continentes, fornecemos abrigo e asilo aos perseguidos. Mais ainda, enfrentamos a morte na forma da peste e vencemos, e o próprio mar, de onde viemos e de quem tomamos o território que habitamos. Somos cosmopolitas por ofício e crença e carregamos conosco, para onde vamos, a salutar arrogância dos que têm história. A arrogância de quem sobreviveu a vicissitudes e violências de diversas ditaduras e intervenções. Mais que qualquer outro no Brasil, o povo santista está preparado para confrontar seu destino.
\end{abstract}

(Ricardo M. da Silva) $^{18}$

\subsection{O Porto do café}

Santos é uma das povoações mais antigas do Brasil. O local onde a cidade se situa, na llha de São Vicente, era chamado pelos índios guaianases na época do

\footnotetext{
${ }^{18}$ SILVA, Ricardo M. da, Sombras sobre Santos: o longo caminho de volta, 1988, p. 161.
} 
descobrimento de Enguaguaçu (que significa "pilão grande", provavelmente devido à forma alongada da área, estendendo-se como uma tripa entre a serra e o mar). $\mathrm{O}$ núcleo inicial da povoação se estabeleceu sobre o Outeiro de Santa Catarina ${ }^{19}$, em terras doadas por Martim Afonso a Brás Cubas, fundador da Santa Casa da Misericórdia, o primeiro hospital do Brasil. Segundo o cronista Frei Gaspar ${ }^{20}$, inicialmente a povoação era chamada simplesmente de Porto, entendendo-se que se tratava do porto da Vila de São Vicente. Porém, após a fundação da Irmandade da Santa Casa, a povoação passou a ser conhecida pelos marinheiros que chegavam enfermos ou adoeciam aqui como Porto de Santos. Essa é uma das explicações para a origem do nome da cidade.

Santos foi até o século XIX uma Vila pequena e sem grande expressão. Uma exígua população vivia do que produzia o mar, de pesca, de atividades econômicas como a extração do sal marinho e a comercialização de óleo de baleia, utilizado para acender os lampiões. Porém, com o deslocamento do centro dinâmico da economia cafeeira das fazendas fluminenses para o Vale do Paraíba e posteriormente para o Planalto Paulista, a partir da década de 1830, o porto de Santos assume uma posição cada vez mais estratégica na economia nacional. O crescimento da cidade e a riqueza de Santos se devem ao Porto e ao "eixo" que a cidade forma com São Paulo, de tal forma que até hoje a maior parte das exportações brasileiras ainda passa pelo Porto.

No final do século XIX, o movimento no Porto de Santos já era vertiginoso. Somente no ano de 1897, foram embarcadas no porto 6 milhões de sacas de café. Poucos anos depois, o porto chegou a monopolizar 95\% do volume das exportações brasileiras. Entre os anos de 1880 e 1929, quando declina a produção de café

\footnotetext{
${ }^{19}$ Onde hoje se situa a Fundação Arquivo e Memória de Santos.

${ }^{20}$ MADRE de DEUS, Frei Gaspar da, Memórias para a história da capitania de São Vicente, 1953, p. 115.
} 
devido à crise do capitalismo mundial, o Brasil já responde por três quartos do comércio mundial de café ${ }^{21}$.

Um dos elementos que permitiram o surto cafeeiro foi a construção da Estrada de Ferro Santos-Jundiaí, pela São Paulo Railway Company, conhecida como "A Ingleza", inaugurada em 1867. De toda a malha ferroviária paulista, era a única estrada de ferro explorada diretamente pela firma inglesa; um investimento altamente rentável, pois implicava o monopólio de toda a produção do interior do estado de São Paulo e de outras áreas vinculadas ao porto de Santos. A Inglesa fazia a ligação entre as fazendas produtoras de café do planalto paulista e o porto de Santos. Antes, as sacas de café eram transportadas com lentidão e muitas perdas no lombo de mulas pela velha Estrada da Maioridade, que ligava Santos a São Paulo. O café que chegava a Santos pela São Paulo Railway ia diretamente para os trapiches dos comissários do café, na área portuária; os comissários eram encarregados de classificar, manipular e misturar as variedades de café a serem exportadas. Fortunas foram feitas na atividade de exportação do café, chegando a ponto de os comissários financiarem a safra dos fazendeiros ${ }^{22}$.

Em 1892, foi inaugurado o primeiro trecho de 260 metros do cais do porto pela Companhia Docas de Santos, a fim de facilitar a atividade exportadora. Em 1922, ficou pronta a sede da Bolsa Oficial do Café, construída pela Companhia Construtora de Santos e financiada pela Associação Comercial de Santos. Um imponente edifício em estilo eclético, encravado no centro histórico de Santos, cuja função era centralizar, organizar e controlar as operações do mercado cafeeiro. Construído em apenas dois anos e com o que havia de melhor e mais caro em termos de materiais na época - cúpulas de cobre, mosaicos de mármore, colunatas de granito - além de

\footnotetext{
${ }^{21}$ VILAS BOAS, Sérgio, Santos: o centro histórico, o porto e a cidade, p. 53.

22 Ibid., p. 47.
} 
esculturas, vitrais e três enormes painéis do pintor Benedito Calixto, o edifício era um monumento à burguesia santista, um verdadeiro totem do capital cafeeiro ${ }^{23}$. Como ressalta a historiadora Ana Lanna, a Bolsa Oficial era uma espécie de "propaganda edificada":

Pretendia difundir a riqueza do café atraindo para São Paulo capitais e trabalhadores. Fica patente nas suas intenções o projeto de cidade e de nação que a elite cafeeira formulara 80 anos antes da edificação desse monumento: a construção de uma nação e seu povo com suporte no capital internacional e nos trabalhadores brancos europeus, que aqui viriam, para com suas noções de progresso e civilidade formar o povo brasileiro, amortecendo os efeitos de 400 anos de escravidão. ${ }^{24}$

Contribuiu para isso o fato de Santos nunca ter sido um grande centro escravista. Pelo contrário, muitos santistas colaboraram intensivamente, através dos clubes abolicionistas e da criação de quilombos, para o fim da escravidão. A partir de 1870, setores cada vez mais amplos da população livre da cidade envolviam-se na luta abolicionista, acoitando escravos, patrocinando fugas, reunindo fundos para obter alforrias, defendendo escravos fugidos na justiça. Os escravos fugitivos das fazendas do interior paulista eram encaminhados pelos caifases ${ }^{25}$ ao quilombo Jabaquara, fundado em 1882 em Santos. A cidade tornourse, na última década do regime escravista, um pólo aglutinador desses escravos em fuga. Em Santos, ao contrário do Rio de Janeiro, o abolicionismo estava intimamente ligado ao

\footnotetext{
${ }^{23}$ Sobre todo o processo de construção da Bolsa Oficial do Café e sua importância no contexto da economia cafeeira, cf. Gino C. Barbosa et alii, O palácio do café, São Paulo, Magma Cultural Editora, 2004.

${ }^{24}$ LANNA, Ana, A transformação urbana: Santos 1870-1920, Revista da USP, oㅡ 41 (1999), p. 108.

${ }^{25}$ Os caifases eram a facção mais combativa do movimento abolicionista paulista. Sob a liderança do advogado Antônio Bento, eles organizavam fugas coletivas, perseguiam capitães-do-mato e ameaçavam senhores de escravos. Os negros foragidos eram enviados ao Quilombo Jabaquara e à Província do Ceará, que era território livre desde 1884. Devido à ação dos abolicionistas, a maioria das cidades paulistas já havia abolido a escravidão antes da Lei Áurea, em 1888. Cf. FONTES, Alice Aguiar de Barros. Prática abolicionista em São Paulo: os caifases (1882-1888), Mestrado, São Paulo: USP/FFLCH, 1976, 161 p.
} 
movimento republicano. Nos anos finais da escravidão, estima-se que cerca de 10 mil negros fugidos tenham se estabelecido em Santos.

A repercussão que teve o movimento abolicionista em Santos se deve, em larga medida, à pujança do jornalismo e da imprensa na cidade. O primeiro jornal da cidade foi a Revista Commercial, fundada em 1859. O Diário de Santos, que começou a circular em 1872, durou 40 anos e foi considerado na época uma verdadeira "escola de jornalismo", modelo para as outras publicações. Entre 1873 e 1914, circularam nada menos do que 150 jornais na cidade, a maior parte de duração efêmera. Eram jornais ligados às colônias de imigrantes (portugueses, italianos, espanhóis, sírio-libaneses possuíam seus veículos), às causas republicana e abolicionista (O Raio, O Piratiny, O Alvor, A Idéia Nova, A Evolução, entre outros) e a clubes ou sociedades beneficentes. O único diário dessa época que dura até os dias de hoje é $A$ Tribuna, fundada em 1894 e, na época, o maior concorrente do Diário. O aparecimento de uma quantidade de jornais em fins do século XIX, como, O Diário de Santos e o Cidade de Santos, facilitou a circulação das idéias abolicionistas e republicanas em Santos e, depois, as reivindicações dos movimentos operários ${ }^{26}$.

A cidade foi declarada território livre em 1886, antes portanto, da abolição oficial. Entretanto, também havia alguns supostos abolicionistas que se aproveitaram da situação para ganhar dinheiro com uma causa humanitária ou obter mão-de-obra barata, num momento em que crescia a oferta de empregos e em que havia dificuldade em conseguir trabalhadores. ${ }^{27}$

Além da força do abolicionismo, também fi forte e combativo o movimento operário em Santos. Em 1889, foi fundado na cidade o primeiro núcleo socialista do

\footnotetext{
${ }^{26}$ RODRIGUES, Olao, História da Imprensa em Santos, Santos, A Tribuna, 1979.

27 LANNA, Ana L. D., Uma cidade na transição. Santos: 1870-1913, 1996, p. 193 et seq.
} 
Brasil, responsável pela publicação "A ação social". ${ }^{28} \mathrm{~A}$ cidade foi palco de algumas das primeiras greves do país, ligadas ao Porto: 1877 (portuários), 1888 (construção civil), 1889 (estivadores e cocheiros). Em 1891, ocorreu na cidade a primeira greve geral do Brasil $^{29}$ iniciada por duas categorias profissionais essenciais para a vida da cidade: os estivadores do porto e os cocheiros de bondes.

A maior parte dos trabalhadores era constituída de imigrantes portugueses e espanhóis, que desembarcavam em contingentes cada vez maiores no porto. A cidade era a porta de entrada dos imigrantes estrangeiros em direção às fazendas de café do interior paulista. Entre 1850 e 1930, teriam chegado aproximadamente 4 milhões e meio de imigrantes. Calcula-se que teriam entrado no país, principalmente em São Paulo, 1.485.000 italianos, 1.321 .000 portugueses e 583.000 espanhóis nesse período. ${ }^{30}$ Durante a República Velha, Santos ficou conhecida como "Barcelona Brasileira", com a emergência de um movimento operário organizado e combativo. $\mathrm{O}$ anarco-sindicalismo constituía a linguagem comum aos trabalhadores do Porto, imigrantes de várias partes do mundo, aos quais se deve, sem dúvida, o caráter multicultural e cosmopolita que marca a cidade portuária até a atualidade. ${ }^{31}$

Após o crash da bolsa de Nova York em 1929, o café entra em colapso. Os preços caem vertiginosamente e a crise econômica leva ao início do processo de industrialização induzido e tutelado pelo Estado autoritário comandado por Getúlio Vargas. As exportações do Porto se diversificam, incluindo os bens de consumo produzidos por empresas subsidiadas pelo Estado. Santos consegue manter seu

\footnotetext{
${ }^{28}$ A Ação Social era editada por Silvério Fontes, médico da Santa Casa de Misericórdia, participante das campanhas abolicionista e republicana e pai do poeta Martins Fontes. O centro socialista estava voltado inicialmente para a divulgação das idéias socialistas e a formação de cooperativas, mas Ihe faltava base social. Posteriormente, ele entra na formação do Partido Operário Socialista, que defende entre suas causas a redução da jornada de trabalho. O poeta Martins Fontes (1884 - 1937) participou, como o pai, da campanha sanitarista, mas em política optou pelo anarquismo de Piotr Krototkin.

${ }^{29}$ Sobre essa greve cf. Maria Lúcia C. Gitahy, Ventos do mar., 1992, p. 79-82.

30 PETRONE, Maria T. Shorer, O imigrante e a pequena propriedade (1824-1930), p.11.

${ }^{31}$ GONÇALVES, Adelton, Barcelona Brasileira, 2003.
} 
perfil portuário, mas são exportados pelo Porto os produtos das indústrias de Cubatão (a Cosipa se instala em Cubatão) e, mais tarde, do Grande ABC. É a época em que se implantam as indústrias de base, destinadas a dar sustentação a um modelo de modernização autoritária. ${ }^{32}$

Em 1937, os portuários deflagraram a primeira greve geral do Estado Novo. Os trabalhadores se recusavam a embarcar uma carga de café destinada às tropas do ditador Francisco Franco, que seria levada à Espanha por um navio da Alemanha nazista. A solidariedade aos revolucionários que resistiam ao fascismo de Franco na guerra civil espanhola foi o motivo da paralisação. No estado de exceção instaurado pelo Estado Novo, qualquer tentativa de paralisação do trabalho era considerada um crime contra a segurança nacional e julgada como traição à pátria por um Tribunal de Segurança. O movimento durou dez dias, no decorrer dos quais o governo de Vargas efetuou prisões e torturas, demissões em massa e decretou intervenção federal em Santos. Ocupado o Porto pelo exército, os estivadores foram obrigados a trabalhar à força, sob as ordens de um coronel integralista. Esse evento foi relatado, em cores heróicas mas com fidelidade aos fatos, pelo escritor Jorge Amado no romance "Os subterrâneos da liberdade".

Durante todo o período do Estado Novo (1937-1945), Santos perdeu sua autonomia (só reconquistada em 1953), por ser considerada área de segurança nacional. É nessa época que se criou o mito da "Moscou Brasileira" e do "Porto Vermelho", por causa da combatividade do movimento dos estivadores e dos sindicatos da região, além da popularidade do PCB, o "partidão" de Luiz Carlos Prestes, entre os trabalhadores ${ }^{33}$. Após 1945, quando os comunistas saem da

\footnotetext{
${ }^{32}$ Relatório Anual da Cosipa, 2003.

33 Sobre o contexto político desse período e os estivadores do Porto, cf. Fernando T. da Silva, $A$ Carga e a culpa. Os operários das Docas de Santos: Direitos e cultura de solidariedade 1937-1968,
} 
ilegalidade, de um total de oito eleições, o PCB obteve sete vitórias na Baixada Santista, com uma plataforma comum com o PTB de Vargas (o mesmo que reprimira os trabalhadores que se negaram a embarcar o café para os fascistas espanhóis). Em Santos, Prestes recebeu 45\% dos votos para as eleições ao Senado em 1945, contra $9 \%$ no país como um todo. O populismo de Vargas e do PTB cooptou o movimento sindical, principalmente através da legislação trabalhista. O PCB, com seu plano de aliança com o populismo, contribuiu muito para a legitimação dessa estratégia de controle do movimento operário, que perdeu a independência e a combatividade que possuía na época do anarco-sindicalismo. ${ }^{34}$

Nessa época, o café já havia perdido a importância que tivera até então. A crise mundial do capitalismo, na década de 30, afetou a economia cafeeira no Brasil. Depois de sucessivas quedas de preço e queima de safras, a Bolsa Oficial do Café foi fechada em 1937 por tempo indeterminado. Foi reaberta em 1942, no contexto do esforço de guerra, passando a se chamar Bolsa Oficial de Café e Mercadorias; além do café, centralizava a exportação e importação de vários outros tipos de mercadorias. Entre 1880 e 1929, o Brasil respondia por aproximadamente três quartos da comercialização de café no mundo; as exportações de café chegaram a representar $75 \%$ de toda a balança comercial brasileira. Porém, após a Segunda Guerra Mundial, o Brasil foi desbancado pelo café produzido na Colômbia, considerado de melhor qualidade e, hoje, o café brasileiro ainda participa com cerca de um quarto das exportações mundiais de café ${ }^{35}$.

São Paulo-Santos, Hucitec-Prefeitura Municipal de Santos, 1995 e Ingrid Sarti, Porto Vermelho. Os estivadores santistas no sindicato e na política, São Paulo, Paz e Terra, 1981.

${ }^{34}$ TAVARES, Rodrigo Rodrigues, Moscouzinha Brasileira, 2007, passim.

${ }^{35}$ VILAS BOAS, Sérgio, Santos; o centro histórico, o porto e a cidade, p. 53. 


\subsection{A transformação da paisagem urbana}

Até o início do século XX, Santos ainda era uma cidade semi-colonial, apesar do crescimento populacional contínuo e das rápidas transformações pelas quais estava passando. Seu destino esteve, desde o princípio, ligado ao da cidade de São Paulo. O historiador Caio Prado Júnior as considerava "cidades casadas", formando um único "sistema" São Paulo-Santos, no qual Santos é o ponto de articulação das comunicações com o exterior, por intermédio do Porto, e São Paulo, o centro de convergência de toda a vida do planalto paulista ${ }^{36}$. A importância desse eixo SantosSão Paulo seria responsável pela preponderância econômica do Estado de São Paulo.

Santos é uma cidade de vocação comercial e portuária. Sem terras próprias para o cultivo da cana-de-açúcar e longe dos distritos de mineração, a Vila sofreu um longo período de declínio e marasmo, entre os séculos XVII e XVIII. Mas o Porto readquiriu aos poucos sua importância estratégica, com a exportação do açúcar produzido no planalto a partir do fim do século XVIII. Duas medidas tomadas pelo então governador Bernardo José M. de Lorena foram decisivas no renascimento do Porto de Santos: em 1789, tornouro o único Porto da Capitania de São Paulo e em 1792, inaugurou uma via, que ficou conhecida como "Calçada do Lorena", ligando o planalto ao litoral. Com isso, o porto de Santos passou a monopolizar as exportações da Capitania de São Paulo, principalmente do açúcar produzido no interior $^{37}$. A cidade adquiriu importância a partir do momento que obteve a exclusividade do tráfego de mercadorias com o planalto: o binômio que formava com São Paulo foi o motivo de sua valorização como cidade portuária.

\footnotetext{
${ }^{36}$ PRADO Jr, Caio. Contribuição para a geografia urbana da cidade de São Paulo, Evolução Política do Brasil e outros estudos, 1958, p. 122 et seq.

${ }^{37}$ CERQUEIRA, Rita Martins et alii, Santos na formação do Brasil: 500 anos de história, 2000, p. 28.
} 
Em 1823, segundo o historiador Francisco Martins dos Santos ${ }^{38}$, a cidade ainda era uma pequena Vila de 4.700 habitantes, dos quais 2.000 eram escravos e 2.700 livres; entre os livres 1.400 eram mestiços. Em 1839, quando a Vila foi elevada à categoria de cidade, Santos era "o tipo apurado de uma povoação colonial sem fortuna e as praias lodosas do porto [...] freqüentadas por bandos de urubus davam a nota característica local". ${ }^{39}$ No decorrer do século XIX, o comércio do açúcar é paulatinamente substituído pelo do café; o Porto torna-se indispensável para a economia nacional, mas faltava à cidade uma infra-estrutura urbana compatível com sua importância estratégica. O período decisivo na transformação da paisagem urbana de Santos é o que vai de 1870 às primeiras décadas do século XX, no decorrer do qual a sua fisionomia se modifica radicalmente: Santos deixa de ser uma cidade semi-colonial para ingressar na modernidade.

O maior problema a ser equacionado era o das epidemias, que assolavam a região. Os dados revelam a magnitude do problema: entre 1891 e 1895, morreram, só de febre amarela, 5.740 pessoas e entre 1890 e 1900 morreram ao total 22.588 pessoas vítimas das epidemias, quase metade da população do município, que em 1900 era de 50.389 habitantes $^{40}$.

Impulsionada pelo crescimento das exportações de café e também de açúcar, a cidade se desenvolve continuamente e passa por um processo acelerado e descontrolado de adensamento da malha urbana. Com a vinda de imigrantes europeus, mas também de migrantes de São Paulo e do nordeste, há expressivo

\footnotetext{
${ }^{38}$ SANTOS, Francisco Martins dos, e LICHTI, Fernando Martins. História de Santos, vol.2, 1986, p. 4.

${ }^{39}$ Observação de Guilherme Álvaro, apud Maria Lúcia C. Gitahy, Ventos do Mar., p. 23.

${ }^{40}$ LANNA, Ana L. D., Uma cidade na transição. Santos: 1870-1913, 1996, p. 52 e 69.
} 
aumento populacional. Em 1890, Santos tinha 13.012 habitantes, passa a ter 88.967 em 1913 e, em 1935, já são 142.059 habitantes $^{41}$.

Mas esse crescimento tem seu custo. A presença da lama negra, típica de mangues e áreas pantanosas, marcava tanto a fisionomia da cidade, que vista à distância do mar, a cidade parecia negra, como observava o escritor Júlio Ribeiro em 1888: "vista do mar, do estuário a cidade é negra: black town lhe chamavam os ingleses". ${ }^{42}$ A insalubridade da cidade era conhecida e afastava dela investimentos e trabalhadores. A cidade foi construída sobre antigos mangues e estava rodeada por áreas pantanosas, além do clima quente e úmido e dos verões prolongados que todo santista conhece bem até hoje. Isso a tornava propícia às infestações: na segunda metade do século XIX, proliferam doenças como a febre amarela, a varíola, a peste bubônica, a difteria, a tuberculose, entre outras moléstias. Contam os relatos que, nos dias de chuva, as ruas sem calçamento transformavam-se em verdadeiros lagos. Quando a maré baixava, enormes lamaçais mal-cheirosos contaminavam a cidade. $^{43}$

As medidas adotadas para controlar as epidemias eram paliativas e ineficientes, como a limpeza das praias, as quarentenas no Porto e a construção de um hospital para isolamento dos doentes. Só foram tomadas providências sérias quando as moléstias começaram a "subir a serra", junto com os passageiros da ferrovia inglesa, ameaçando a cidade de São Paulo.

Obrigado a tomar atitudes, o governo da província instituiu duas comissões, independentes da municipalidade e diretamente subordinadas ao governo estadual: a Comissão Sanitária, responsável por vistoriar habitações, promover desinfecções e

\footnotetext{
${ }^{41}$ ANDRADE, Wilma Therezinha et alii, Presença da Engenharia e arquitetura - Baixada Santista, 2001, p. 61.

${ }^{42}$ GITAHY, Maria Lúcia C., Ventos do Mar, 1992, p. 23.

${ }^{43}$ LANNA, Ana L. D., Uma cidade na transição. Santos: 1870-1913, 1996, passim.
} 
fiscalizar a limpeza de quintais e terrenos baldios, e a Comissão de Saneamento, responsável pelas obras de canalização de água e pela construção da rede de esgotos. ${ }^{44}$ Para higienizar a cidade e implementar um plano urbanístico, foi contratado o engenheiro Saturnino de Brito. Era preciso remodelar o traçado das ruas, modernizar o Porto e prevenir a ocorrência de infestações. Saturnino formulou seu plano, posto em prática a partir de 1905, com o engenhoso sistema de canais de drenagem, ainda em pleno funcionamento hoje.

A afluente burguesia da região, composta principalmente pelos comissários do café, impulsiona a expansão urbana da cidade. Na passagem do século XIX para o século XX, começa a circular o sistema de bondes, inicialmente puxados por burros, antes da eletrificação das linhas em $1909 .{ }^{45} \mathrm{~A}$ iluminação pública passa do sistema a gás para a eletricidade em 1904. Nos bairros ricos são edificados casarões e palacetes, surgem hotéis caros e cassinos na orla e no Monte Serrat. Abrem-se as Avenidas Conselheiro Nébias e Ana Costa (calçadas e iluminadas). Há mudanças de hábitos: os santistas começam a freqüentar as praias e a expor seus corpos ao sol. O último canal, conforme o projeto de Saturnino, é construído em 1927, completando o processo de transformação da paisagem urbana santista. ${ }^{46}$

Paralelamente, os trabalhadores portuários e os descendentes dos escravos libertos vão sendo empurrados para os morros, num modelo excludente de ocupação do espaço urbano típico das grandes cidades brasileiras. Em Santos, forma-se o primeiro contingente significativo de proletariado urbano do Estado de

\footnotetext{
${ }^{44}$ BERNARDINI, Sidney Piochi, Os planos da cidade: as políticas de intervenção urbana em Santos de Estevan Fuertes a Saturnino de Brito (1892 - 1910), 2006.

${ }^{45}$ SANTOS, Ricardo Evaristo e MATOS, Paulo. Transporte coletivo em Santos: história e regeneração, 1987.

${ }^{46}$ Centenário dos Canais: a obra de Saturnino de Brito - Palestra da prof $\stackrel{a}{\text { a e }}$ dra . Wilma Therezinha Fernandes de Andrade, proferida em 25 de agosto de 2005 na CEV (Comissão Especial de Vereadores) dos canais.
} 
São Paulo. O processo de higienização foi também um processo de segregação espacial. É isso o que ressalta a historiadora Ana Lanna:

[...] encontramos a população local sendo atacada, transformada e responsabilizada por todos pelas mazelas e vícios da cidade. É sobre ela que estas intervenções "modernizadoras" recairão com violência, definindo novos lugares./ A discussão e implementação de uma cidade higiênica e bela e associação entre salubridade física e social foi uma das formas fundamentais de generalização dos valores burgueses, de controle desta população móvel e instável. ${ }^{47}$

O Porto de Santos foi fundamental na constituição de um complexo portuário capitalista no Brasil. Ao contrário do porto do Rio de Janeiro, mantido pelo Estado, o porto de Santos era administrado por uma empresa privada sob concessão do governo. Após duas tentativas do poder público de construir um porto, a Companhia Docas de Santos recebeu uma concessão para construí-lo e explorá-lo por 90 anos, de 1890 a 1980. A partir daí e até agora, o controle da administração do porto santista passou para a Companhia Docas do Estado de São Paulo (Codesp), ligada ao governo federal. Desde as primeiras tentativas de construir o Porto, desenvolveuse um conflito entre a Companhia Docas e os comerciantes da cidade, donos das pontes e trapiches que se encontravam no local de construção do cais. As obras se iniciaram em 1892 e prosseguiram até 1909, quando o cais, dotado de armazéns, pátios, frigorífico e linha férrea, atingiu 4.720 metros de rampa ${ }^{48}$. A construção do Porto e o saneamento da cidade podem ser considerados obras interligadas, fazendo parte de todo o processo através do qual se reestruturou a paisagem urbana de Santos.

\footnotetext{
47 LANNA, Ana L. D., Uma cidade na transição. Santos: 1870-1913, 1996, p. 80.

${ }^{48} \mathrm{O}$ movimento de mercadorias no Porto cresce exponencialmente, devido às obras. Em 1860 o movimento no Porto foi de 36.250 sacas de café, em 1895 foi de 2 milhões de sacas e em 1909 atingiu a marca de 13.130 .933 sacas exportadas. Dados de Maria Lúcia C. Gitahy, Ventos do Mar., p. 30.
} 
A Companhia Docas, o "império de Guinle", pode ser considerado o maior grupo capitalista brasileiro da época e um dos maiores impérios empresariais do capitalismo no Brasil ${ }^{49}$. Mas, se em Santos se faz sentir a força do Capital, nos inícios da industrialização brasileira, também do outro lado, o do trabalho, se faz sentir a força do trabalhador: Santos foi palco de um dos movimentos de trabalhadores mais fortes e bem organizados do Brasil, sob a liderança da categoria dos estivadores. Na época dos imigrantes, podia-se falar verdadeiramente numa "Babel portuária", composta por trabalhadores das mais variadas origens e com diversos interesses e cuja organização foi tarefa do Sindicato dos Estivadores de Santos.

A mão-de-obra para as atividades da estiva passa a ser controlada, a partir de 1930, pelo Sindicato dos Estivadores, que negociava diretamente com a Companhia Docas tudo o que se referia a salários, horários e condições de trabalho. Se, por um lado, isso reforçou muito o peso político e capacidade de negociação dos trabalhadores do Porto, por outro, criou problemas, pois com a concentração das exportações no Porto de Santos, os portuários podiam paralisar a economia. ${ }^{50} \mathrm{O}$ sindicato dos trabalhadores portuários, organizado pelo modelo corporativista que a CLT de Vargas instituiu, foi considerado uma das causas do elevado custo do Porto de Santos. Nas décadas de 1980 e 1990, generalizam-se na imprensa as reclamações contra a chamada "Máfia dos Portos", que estaria prejudicando as exportações brasileiras e contribuindo para aumentar o chamado "custo Brasil". 51

\footnotetext{
49 Sobre a formação da Cia. Docas, sua importância e os conflitos que gerou, cf. Cezar Honorato, $O$ polvo e o porto. A Cia Docas de Santos (1888-1914), São Paulo-Santos, Hucitec-Prefeitura Municipal de Santos, 1996.

${ }^{50}$ FILHO, Brito. Direito Sindical: Análise do Modelo Brasileiro de Relações Coletivas de Trabalho a Luz do Direito Comparado, 2000.

${ }^{51}$ Revista Veja no. 1235, 13 de maio de 1992.
} 
Nas décadas de 1940 e 1950, o Porto continua a ser a principal atividade econômica de Santos. O aumento populacional e o advento do turismo, após a abertura da Via Anchieta, provocam um re-arranjo da cidade. Os casarões das avenidas próximas à praia cedem lugar aos grandes edifícios de apartamentos, enfileirados ao longo da orla, de São Vicente à Ponta da Praia. Os bairros onde antes habitavam os operários, como Macuco, Vila Belmiro, Marapé e Jabaquara, passaram a ser residência da classe média. A arquitetura típica desses bairros operários eram os chalés de madeira, construídos sobre pilaretes em ruas geralmente sem calçamento. A especulação imobiliária (num processo que se repete até hoje em todo o litoral paulista), deslocava a população pobre cada vez mais para as encostas dos morros, onde não havia nenhuma infra-estrutura e riscos de desabamento. Na década de 1940, dos 180 mil habitantes da cidade, 15 mil residiam nos morros, destes $50 \%$ eram portugueses, $10 \%$ espanhóis e o restante composto de nordestinos e mineiros ${ }^{52}$.

A partir dos anos 50, e principalmente após a construção da Via Anchieta, entre 1947 e 1953, a cidade se verticaliza aceleradamente, com a construção de edifícios e conjuntos residenciais ao longo de toda a orla. Num intenso processo de loteamento e especulação imobiliária, valorizam-se cada vez mais as áreas próximas à orla, ocasionando a expulsão da população pobre e a conseqüente favelização, com a construção de habitações precárias nas encostas dos morros e Zona Noroeste $^{53}$. A classe média paulistana desce a Serra, adquire imóveis utilizados como segunda residência, intensificando o processo de urbanização. As

\footnotetext{
${ }^{52}$ BEIGUELMAN, Paula, Morros santistas, Sociologia, no 10 (1945), p. 32. Cf. também ARAúJO Filho, José Ricardo, "A expansão urbana de Santos", in: A Baixada Santista: aspectos geográficos, São Paulo, Edusp, 1965.

${ }^{53} \mathrm{Com}$ o crescimento populacional de Santos derramando-se pela zona Leste da ilha de São Vicente, do Centro até a Ponta da Praia, e aí atingindo o limite, começou o processo no sentido contrário, para ocupar as áreas que, em 1976, ganhariam oficialmente o nome de Zona Noroeste de Santos e que hoje é formada por 12 bairros.
} 
aglomerações urbanas geram problemas, como a contaminação das águas e das praias pelo lançamento de efluentes domésticos e a poluição da atmosfera pelos gases tóxicos liberados no pólo petroquímico de Cubatão ${ }^{54}$. As atividades de veraneio diversificam o perfil da cidade, com expansão das atividades comerciais e de prestação de serviços. Nessa época, Santos começa a adquirir a fisionomia que tem hoje, num processo contínuo de urbanização dos espaços e aglomeração de populações, interrompido apenas pelos vinte anos de ditadura militar, quando a cidade perde sua autonomia (1964-1984) e sofre um processo de degradação da vida urbana, o que discutiremos no próximo item.

\subsection{A intervenção militar}

Santos já havia estado sob intervenção em 1930, após o golpe de Estado de Getúlio Vargas. De 1931 a 1937, os prefeitos subordinados ao governo estadual, governavam sem a Câmara Municipal. Em 37, com o golpe que instituiu o regime de exceção do Estado Novo os prefeitos passam a ser nomeados pela Interventoria Federal em cada Estado. A autonomia só foi restaurada em 1953, um ano antes do suicídio de Vargas, mas não durou muito; pouco mais de dez anos após a reconquista da autonomia, outro regime de exceção se institui, subtraindo novamente a independência de Santos. ${ }^{55} \mathrm{O}$ valor estratégico do Porto, o perfil cosmopolita que adquiriu após as reformas urbanas e a força que os movimentos sociais manifestaram na cidade, todos esses fatores, fizeram com que Santos fosse

\footnotetext{
${ }^{54}$ Sobre a urbanização de Santos e Baixada ao longo da segunda metade do século XX e, em especial, sobre os problemas ecológicos resultantes de um modelo de urbanização descontrolado e especulativo, cf. Cíntia Maria Afonso, A paisagem da Baixada Santista. Urbanização, transformação e conservação, São Paulo, Edusp-Fapesp, 2006.

${ }^{55}$ SILVA, Ricardo M. da, Sombras sobre Santos: o longo caminho de volta, 1988, passim.
} 
considerada potencialmente perigosa e, por isso, sujeita à intervenção de regimes e governos autoritários.

Em 24 de abril de 1964, aportou no estuário de Santos, próximo da Ilha Barnabé, o navio-presídio "Raul Soares". Destinado a suprir a falta de presídios para encarcerar os presos detidos pela ditadura, o Raul Soares abrigou inicialmente 40 sargentos contrários ao golpe e depois médicos, professores, operários, políticos e líderes sindicais, que faziam parte do contingente de opositores que diariamente era preso após o golpe militar. Em 23 de abril, $A$ Tribuna publicava a notícia:

Por serem comprovadamente comunistas ou por estarem apontados como comprometidas em movimentos de agitação e subversão reinantes no País antes da vitória da revolução democrática [sic], acham-se recolhidas no presídio de Santos, à disposição do DOPS, mais de sessenta pessoas.

Santos era uma cidade considerada perigosa para os golpistas, por sua posição estratégica, por causa do Porto e, principalmente, pela tradição oposicionista desde o fim do século XIX, que ajudou a consolidar a fama da "Barcelona brasileira" e depois da "Moscou brasileira". Para criar uma opinião pública favorável ao golpe, os militares difundiram o mito da "Cidade Vermelha" (ainda que, no sindicalismo santista, predominassem os trabalhistas e os católicos, os comunistas sendo minoria), antro de conspiradores comunistas, onde os sindicatos armazenariam fuzis e metralhadoras em suas sedes, preparando a revolução socialista ${ }^{56}$.

O militar santista Erasmo Dias, major do exército e um dos líderes do golpe de 64, afirmou em entrevista:

\footnotetext{
${ }^{56}$ SILVA, Ricardo M. da, Sombras sobre Santos: o longo caminho de volta, 1988, passim.
} 
Santos foi onde a revolução correu maior perigo, maior risco. A cidade era como um ponto de partida, a própria origem da revolução. Porque aqui o esquerdismo adquiriu uma força potencial que não existia no Brasil inteiro. A Câmara de Santos era dominada pelos comunistas, o prefeito de Santos era ligado aos comunistas, toda a potencialidade política de Santos estava nas mãos do que eu costumo chamar de peleguismo sindical comunista. Essa força vinha do sindicalismo. Aqui tinha um tal de Fórum Sindical de Debates que era uma espécie de soviete, que para mim foi o primeiro soviete que tentaram implantar no Brasil, para a revolução socialista. Eles paravam Santos quando queriam. ${ }^{57}$

O movimento sindical santista se uniu para convocar uma greve geral como forma de resistência ao golpe militar. Houve paralisação no Porto, no serviço de bondes, nos trens da Estrada de Ferro Santos-Jundiaí, na Refinaria Presidente Bernardes e na Cosipa, além de outras indústrias de Cubatão. ${ }^{58}$ Como resposta, o exército invadiu, por ordem do governador Adhemar de Barros, as sedes dos sindicatos. A intervenção em Santos foi comandada por Júlio de Sá Bierrenbach, que foi nomeado capitão da Capitania dos Portos e recebeu "plenos poderes" para atuar. Além dos sindicatos, também foi ocupada a refinaria Presidente Bernardes, de importância estratégica, pois nela era produzido o combustível que alimentava os tanques e veículos do exército.

A greve na refinaria, organizada pelo Fórum Sindical de Debates $^{59}$ e o Sindipetro (o sindicato dos petroleiros), tinha a função de cortar o fornecimento de combustível às forças armadas. Apesar das ameaças dos militares, liderados por Erasmo Dias, a usina não voltava a funcionar, pois os técnicos em greve se recusavam a colaborar (não havia como identificá-los, para obrigá-los a por o maquinário em funcionamento, no meio da multidão em greve). Havia ameaça de explosão da refinaria e a tentativa de sabotar a gasolina já produzida,

\footnotetext{
${ }^{57}$ SILVA, Ricardo M. da, Sombras sobre Santos: o longo caminho de volta, 1988. p. 14.

58 Ibid. passim.

59 Influenciado pela ideologia do trabalhismo, o Fórum Sindical de Debates surgiu no final da década de 1950, aglutinando mais de 50 sindicatos. Teve papel importante nas grandes greves que pararam Santos nos primeiros anos da década de 1960.
} 
acrescentando-Ihe um derivado de chumbo $^{60}$ (que levaria o motor a fundir, se utilizada). Apesar das prisões e demissões em massa, o movimento ainda continuou por 21 dias. Os detidos foram enviados para a Fortaleza de Itaipu, antigo forte na Praia Grande.

Temendo o desabastecimento de combustível, o governo brasileiro pediu ajuda aos EUA, que enviaram em direção ao Porto de Santos quatro petroleiros com 136 mil barris de petróleo, na operação militar que ficou conhecida como Brother Sam. exército americano disponibilizou uma esquadra inteira (quatro petroleiros, um portaaviões, seis destróieres, aviões de caça etc) a fim de fornecer apoio tático e logístico aos golpistas, caso faltassem armas ou combustível. A esquadra, porém, não chegou ao Porto, embora estivesse de prontidão no Atlântico Sul, próxima da costa brasileira. A ajuda se tornou desnecessária devido à fácil vitória dos militares e à rápida desarticulação da resistência ao golpe de Estado no país. ${ }^{61}$

Com a intervenção militar, na prática, o poder era exercido pela Capitania dos Portos. O prefeito José Gomes, eleito em 1961, tinha sido deposto, junto com o presidente da Câmara, João Inácio de Souza, e vários vereadores. Houve demissões em massa no funcionalismo público, perseguições e cancelamento de aposentadorias. Muitos foram convocados para depor na Capitania dos Portos e delatar colegas, vizinhos ou conhecidos, motivados pelo medo de ser presos. Mas, apesar das arbitrariedades, setores da sociedade ligados à Igreja deram sustentação ao golpe e à intervenção militar. Os líderes estudantis dos centros acadêmicos das faculdades santistas, predominantemente católicas, deram total apoio à ação repressiva dos militares, inclusive oferecendo-se para atuar na caçada

\footnotetext{
${ }^{60}$ Segundo o sindicalista Geraldo Silvino de Oliveira, na época presidente do Sindipetro, foi o próprio presidente da Petrobrás, general Olvino Ferreira Alves, que teria mandado contaminar a gasolina, com um telefonema a Geraldo. O general foi preso em 3 de abril. Cf. Silva, Ricardo M. da, Op. Cit., p. 44 e seg

${ }^{61}$ SILVA, Ricardo M. da, Sombras sobre Santos: o longo caminho de volta, 1988, passim
} 
aos opositores. A "caça às bruxas" em Santos foi capitaneada por um grupo de mulheres católicas, pertencentes à "União Cívica Feminina", que se organizaram para marchar em defesa da família, da pátria e da religião, acompanhando movimentos semelhantes ocorridos nos outros estados do país. ${ }^{62}$

Em São Paulo, os movimentos de mulheres católicas e de classe média, em apoio ao golpe, ficaram conhecidos como a "marcha da família com Deus pela liberdade". Até 20 de abril, 500 pessoas já haviam sido presas ${ }^{63}$. O clima na cidade era de terror: prisões diárias, espancamentos, torturas, cassações, inquéritos policiais.

Em 1968, a repressão militar se intensifica, com a censura a jornais, revistas, livros, músicas, peças de teatro e filmes. Em 26 de junho de 1968, acontecia a Passeata dos Cem Mil, no Rio de Janeiro, na tentativa de rearticular as forças de oposição na resistência ao estado de exceção. Os líderes dos estudantes que participavam do congresso clandestino da União Nacional dos Estudantes (UNE), que havia caído na ilegalidade, foram presos em lbiúna, onde se realizava o congresso, e levados à Fortaleza de Itaipu, utilizada durante a Revolução Constitucionalista de 1932 e, agora, transformada em prisão improvisada. No ano anterior (1967), entrara em vigor a nova Constituição, legitimando a série de atos institucionais que restringiram as liberdades civis e incorporando o autoritarismo na lei. ${ }^{64}$

No final de 1968, ocorrem as últimas eleições diretas em Santos. Fora eleito, com expressiva votação, Esmeraldo Tarquínio, político negro e de esquerda. Tarquínio começou elegendo-se vereador pelo PSB, participou da fundação da Ação Socialista e integrou o MTR (Movimento Trabalhista Renovador, dissidência do PTB

\footnotetext{
62 MELO, Lídia Maria de, Raul Soares, um navio tatuado em nós, 1995, passim..

${ }^{63}$ SILVA, Ricardo M. da, Sombras sobre Santos: o longo caminho de volta, 1988, p. 72.

${ }^{64}$ Folha de São Paulo, 13 de outubro de 1968.
} 
de Vargas e João Goulart), pelo qual elegeu-se deputado estadual em 1962. Foi eleito prefeito de Santos pelo MDB, pois o Al2 havia instituído o bipartidarismo no país, pondo na ilegalidade os demais partidos políticos. A população exultava, porém no início de 1969, após o Al-5, Tarquínio foi deposto, numa onda de cassações que também subtraiu os direitos de políticos santistas como Mário Covas, Gastone Righi, Athiê Jorge Cury e Oswaldo Justo (Justo viria a ser o primeiro prefeito eleito de Santos após a redemocratização, em 1984) ${ }^{65}$. A Câmara Municipal foi fechada e só reaberta em 1970. Santos perdia novamente a autonomia municipal; o prefeito passou a ser nomeado pelo Governo do Estado: são os chamados prefeitos "biônicos", indicados pelo poder central, sem nenhuma identificação com a cidade e seus habitantes e sem a possibilidade do controle democrático de suas ações. $^{66}$

Mesmo com o processo de reabertura, iniciado no fim dos anos 70, Santos só retomou sua autonomia em 1984, quando deixou de ser considerada área de segurança nacional. Contudo, a cidade estava endividada, seus equipamentos urbanos deteriorados e abandonados e sua população desanimada, não só pelo longo e duro período de intervenção militar, mas também pela crise econômica, o desemprego e o arrocho salarial que assolaram o Brasil nos anos de 1980.

A cidade se recuperaria aos poucos, ao longo das últimas décadas, num paulatino processo de revitalização. A modernização das instalações do porto manteve a sua liderança no mercado nacional, mas acabou provocando desemprego devido à automatização da grande maioria das atividades. Vários terminais foram privatizados e hoje são administrados por concessionárias.

\footnotetext{
${ }^{65}$ LA SCALA JUNIOR, Francisco, Justo, uma trajetória de honradez, 2007, passim.

66 SILVA, Ricardo M. da, Sombras sobre Santos: o longo caminho de volta, 1988, passim
} 
A partir dos anos 90, a alternativa encontrada pela administração pública foi investir na revitalização paisagística da cidade, a fim de atrair fluxos turísticos e incentivar empresas do setor de serviços a se instalarem em Santos. Entre essas ações podemos citar a revitalização da área central da cidade, a construção da ciclovia, a implantação do Bonde turístico e a reativação do Teatro Coliseu. Hoje, Santos pode ser considerada uma das cidades com melhor qualidade de vida do país. 


\section{CAPÍTULO 2}

\section{José Herrera, o fotógrafo de Santos}

"Todas as fotos feitas são importantes, mas a mais importante será sempre aquela que não conseguimos fazer".

"Fotografei de tudo, desde reis da bandidagem, do futebol e coroados reais, até as tristezas provenientes de catástrofes e miséria".

(José Dias Herrera)

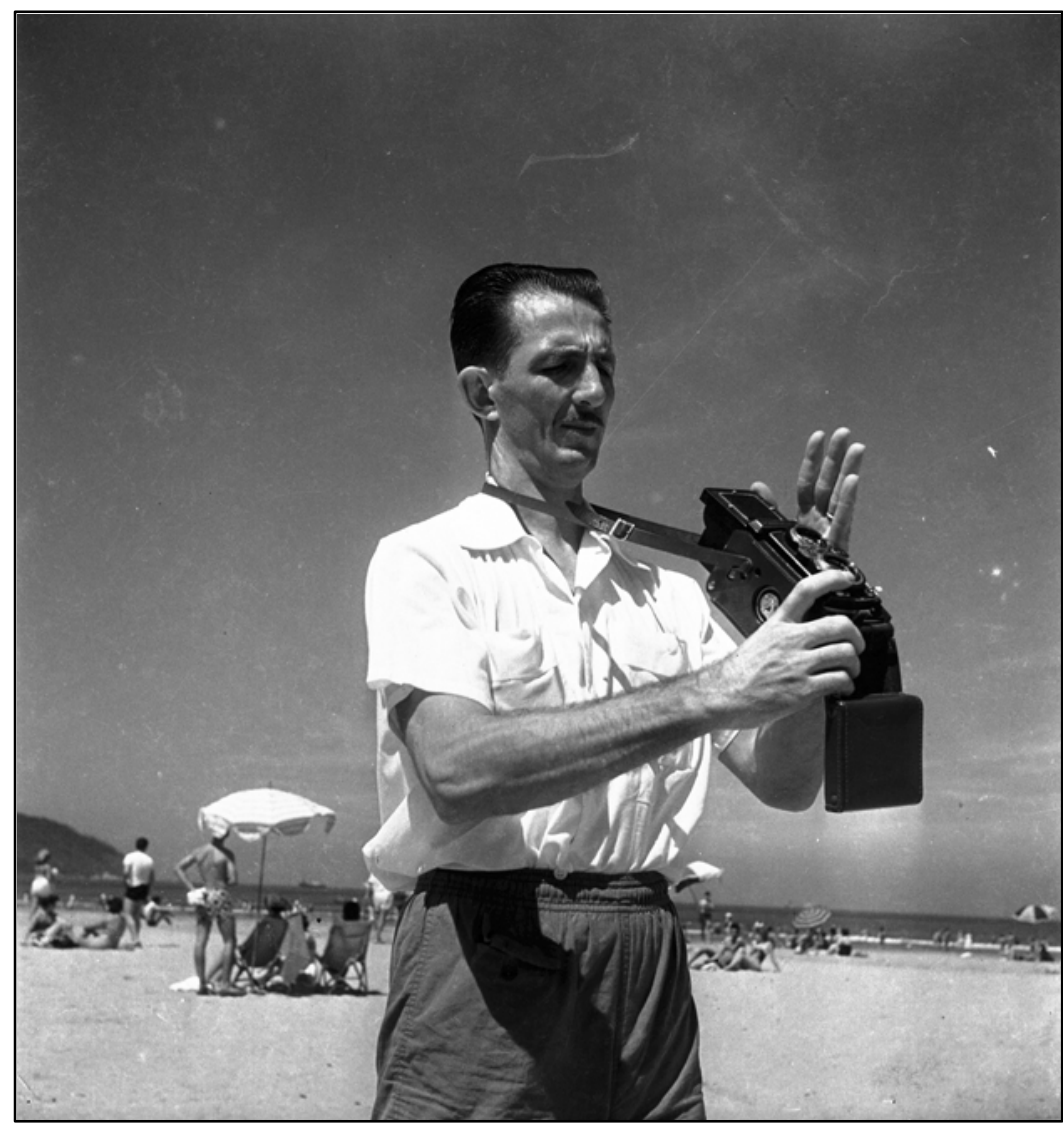




\subsection{Os pioneiros da fotografia}

No início da década de 1850, a daguerreotipia estava em franca expansão no Brasil. Nessa época, em Santos, já era recorrente a presença de fotógrafos viajantes e começavam a instalar-se os primeiros estúdios, atrás de potenciais mercados consumidores. ${ }^{67}$

Em agosto de 1852, encontrava-se em funcionamento um dos primeiros estabelecimentos fotográficos de Santos, montado pelo retratista Justiniano José de Barros, que utilizava o daguerreótipo como suporte técnico. Estabelecido à Rua do Campo, 91, Barros permaneceu pouco tempo na cidade, mas foi um dos primeiros daguerreotipistas do país, atuando desde 1850 no Paraná. ${ }^{68}$

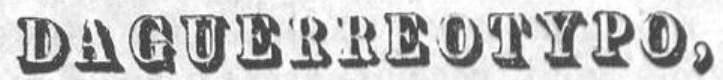 \\ RUA DO CAMPO N 91.}

JUSTINIANO José de Barros, retratista do Daguerreotypo, participa ao respeitavel publico d'esta cidade que tira retratos todos os dias seja qual for o tempo, e de todos os tamanhos; sendo para um botão, até o maior tamanho que se póde tirar no mesmo Daguerreotypo; tira em fumo e coloridos. O artista convida ao respeitavel publico para visilarem sua galleria, afim de verem seus trabalhos: acha-se na mesma officina um rico e variado sortimento de quadros, caixinhas, medalhões \&c. para os mesmos retratos, tudo do melhor gosin.

Anúncio no jornal santista Revista Commercial, em 10 de agosto de 1867. Reprodução do livro Santos e seus Arrabaldes - Álbum de Militão Augusto de Azevedo.

\footnotetext{
${ }^{67}$ BARBOSA, Gino Caldatto, Santos e seus Arrabaldes - Álbum de Militão Augusto de Azevedo, 2004, passim.

${ }_{68}$ KOSSOY, Boris, Dicionário Histórico-Fotográfico Brasileiro. Fotógrafos e Ofício da Fotografia no Brasil (1833-1910), 2002, p.75.
} 
Como Barros, vários outros fotógrafos viajantes registraram a Santos da segunda metade do século XIX, já que a cidade se posicionava quase como rota obrigatória desses profissionais, atraídos pela potencialidade econômica que o crescimento do porto e a construção da Estrada de Ferro São Paulo Railway indicavam. Por Santos, circulavam diariamente viajantes e imigrantes, embarcava-se café e desembarcava-se todo o tipo de novidade vinda da Europa. Por conta disso, a população santista tinha acesso aos mais modernos costumes e a uma vasta gama de informações.

Por essa época, passaram por Santos os fotógrafos: Eduardo Gnérin, retratista, que montou um ponto comercial na Rua Áurea, 74\%9; Henrique Deslandes, daguerreotipista, se instalou por poucos dias na Travessa da Alfândega esquina com a Rua do Rosário ${ }^{70 ;}$ Domingos Portugal, comercializava cartes-de-visite e tirava retratos das 7 da manhã às 4 da tarde ${ }^{71}$, e André Neddermann, que atendia ao público nos fundos de uma casa incendiada, na Rua Santo Antônio, $26^{72}$, entre outros.

André Neddermann foi um dos pioneiros na utilização da foto-pintura, em Santos, em 1861, seguido por Nicolau Huascar ${ }^{73}$, retratista a óleo que percorreu o Brasil comercializando foto-pintura. A técnica consistia na coloração manual das imagens retratadas por meio de pintura a óleo, aquarela, pastel e crayon, obtendo um resultado diferenciado.

\footnotetext{
${ }^{69}$ Revista Commercial, 26/04/1858, p.4.

${ }^{70}$ Revista Commercial, 24/12/1858, p.4.

${ }^{71}$ Revista Commercial, 13/05/1865, p.4.

72 Revista Commercial, 23/07/1861, p.4.

${ }^{73}$ Revista Commercial, 09/01/1862, p.3.
} 
O encontro da fotografia com a pintura contribuiu para a definição de uma nova estética, que alcançou enorme sucesso no país ${ }^{74}$ e determinou o surgimento do fotopintor. $^{75}$

Até mesmo o renomado pintor santista Benedito Calixto valeu-se dessa técnica. Em 1887, ele inaugurou, em parceria com Alderico Lustosa, na Rua do Rosário, um estúdio para produção em fotopintura ${ }^{76}$. O ateliê contava com os melhores equipamentos e "com pessoal habilitado para quaisquer trabalhos, tanto de fotografia, como de pintura". 77

Para Calixto, a fotografia era um instrumento de trabalho indispensável, que não apenas servia para abreviar o tempo ao ar livre ${ }^{78}$, mas se mostrava aliada importante nas composições de teor histórico que desenvolveu nos séculos XIX e XX. Para tanto, valeurse muitas vezes de fotografias tiradas por ele mesmo ou por profissionais como Militão Augusto de Azevedo, cujas imagens serviram de base para a série sobre a antiga cidade de São Paulo, encomendada por Affonso Taunay para o Museu Paulista, em 1917.

Militão Augusto de Azevedo, jovem ator que trocou o teatro pela carreira fotográfica, desembarcou em Santos nos primeiros anos da década de $1860^{79}$ e pode ser considerado um dos principais fotógrafos da cidade de Santos, da segunda metade do século XIX. Ele retratou a paisagem santista num momento em que a cidade ainda era um arrabalde tímido e semi-colonial. Em 1865, foi publicado o álbum Santos e seus Arrabaldes, composto de grandes panoramas e tomadas parciais que retratam o casario de pedra, os pátios de terra batida, os animais de

\footnotetext{
${ }_{74}^{74}$ FERREZ, Gilberto. A Fotografia no Brasil. 1840-1900, 1985, p. 34.

75 TURAZZI, Maria Inez. Poses e Trejeitos - A Fotografia e as Exposições na Era do Espetáculo (1839-1889). 1995, p. 112.

${ }_{77}$ ALVES, Caleb Faria, Benedito Calixto e a Construção do Imaginário Republicano. 2003, p. 113.

${ }_{77}$ Diário de Santos, 18/12/1887.

${ }^{78}$ ALVES, Caleb Faria, Benedito Calixto e a Construção do Imaginário Republicano. 2003, p. 113.

79 BARBOSA, Gino Caldatto, Santos e seus Arrabaldes - Álbum de Militão Augusto de Azevedo. 2004.
} 
carga nas ruas, as igrejas geminadas, a construção da ferrovia e um porto ainda pequeno e acanhado. No estilo típico dos álbuns de Militão, vemos uma paisagem quase fantasmagórica, feita de ruas e construções que parecem ter parado no tempo e completamente desprovida de pessoas.

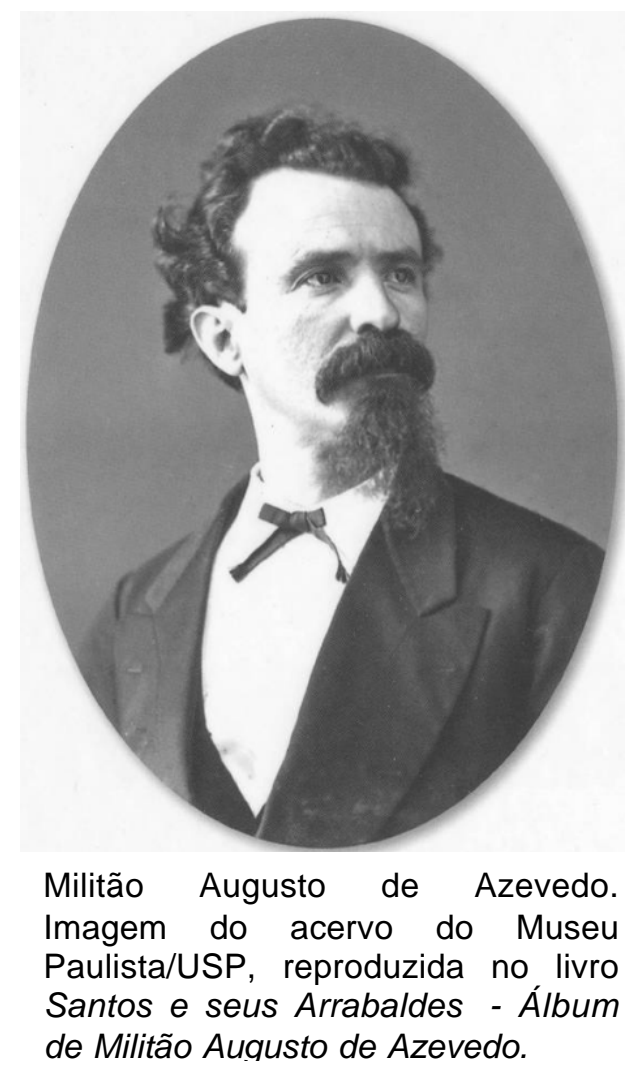

Militão flagrou uma cidade de Santos pacata, anterior às transformações urbanas e sociais que, entre as últimas décadas do século XIX e o início do século XX, modificaram completamente sua paisagem. Já fotógrafos como Marc Ferrez e Guilherme Gaensly foram atraídos (o primeiro no final do século XIX e o segundo no início do século $\mathrm{XX}$ ) pela modernização do porto de Santos, fotografando e documentando todo o processo de transformação, que tornou Santos a principal cidade portuária do Brasil. 
Nas últimas décadas do século XIX, o mercado fotográfico era promissor em Santos e atraiu um significativo número de fotógrafos alemães para a cidade como Fritz Büsch ${ }^{80}$, Julius Nickelsen, Hermann Adolf Johanes Eckmann ${ }^{81}$.

Ainda no final do século XIX, Santos acolheu o fotógrafo José Marques Pereira, comerciante que tratava a fotografia como atividade amadora, atuando, primeiramente, no ramo de fazendas e armarinhos, até dedicar-se exclusivamente ao universo das imagens, o que fez com maestria. $O$ português José Marques Pereira, que imigrou para o Brasil em 1893, fotografou pontos turísticos, monumentos, ruas e praças centrais de Santos numa série de cartões postais, entre 1902 e 1903. São 220 imagens que documentam o surgimento de uma cidade moderna e cosmopolita no lugar do velho arrabalde colonial e, ao mesmo tempo, produzem uma imagem destinada a popularizar o lugar e possibilitar fluxos turísticos. Nessa época, os cartões postais foram muito importantes na popularização das imagens fotográficas. ${ }^{82}$

Destacamos ainda, a atuação da fotógrafa Sophia Pretzel Waldheim, no Álbum do Centenário, publicado em 1939 pela fotógrafa em comemoração aos 100 anos da elevação de Santos à categoria de município, as fotos de José Marques Pereira foram reeditadas, junto com as da própria fotógrafa, o que permite contrastar dois momentos no processo de modernização de Santos e de construção da memória visual da cidade. ${ }^{83}$

\footnotetext{
${ }^{80}$ VASQUEZ, Pedro Karp. Fotógrafos Alemães no Brasil do Século XIX. 2000, p. 180.

${ }^{81}$ CORNEJO, Carlos e GERODETTI, João Emílio. Lembranças de São Paulo - O Litoral Paulista nos Cartões-Postais e Álbuns de Lembranças. 2001, p. 186.

${ }^{82}$ Sobre os cartões postais de José Marques Pereira, cf. LOBO, Maurício Nunes. Imagens em circulação. Os cartões postais produzidos na cidade de Santos pelo fotógrafo José Marques Pereira no início do século $X X$, Dissertação (Mestrado em História), Campinas: Instituto de Filosofia e Ciências Humanas da Universidade Estadual de Campinas, 2004.

${ }^{83}$ Este álbum não foi reeditado. Ele faz parte do acervo iconográfico da Fundação Arquivo e Memória de Santos (FAMS).
} 
Já na primeira metade de século XX despontou em Santos uma nova geração de importantes fotógrafos: José Bidschovsky, Emílio Rouede, Rodolfo Gruther, Emílio Gottschaek, Carlos Weise, Pedro Peresin, Rafael Herrera e seu irmão José Dias Herrera, objeto desta pesquisa. ${ }^{84}$

Como pudemos constatar, José Dias Herrera teve ilustres antecessores na documentação da paisagem santista e na edificação de uma memória visual da cidade. $\mathrm{O}$ que o distingue é o caráter mais explicitamente documental de sua atuação a serviço dos órgãos de imprensa, o que direciona e codifica o seu olhar. Herrera começa a atuar precisamente num momento em que a imagem fotográfica torna-se o coadjuvante necessário do texto e da notícia, funcionando como documento ou testemunho que comprova que um determinado evento efetivamente ocorreu.

\subsection{O nascimento de um fotógrafo}

José Dias Herrera nasceu em 15 de abril de 1920, no Brás, na época um dos mais típicos bairros operários de São Paulo. Lá viviam imigrantes das mais diversas origens, principalmente italianos, portugueses e espanhóis que vinham para a cidade de São Paulo trabalhar na nascente indústria paulistana. Herrera era filho de imigrantes espanhóis. O pai, Rafael Herrera Navarro, era originário da cidade portuária de Málaga, no extremo sul da Espanha, e a mãe, Thomaza Dias Caparroz, da cidade de Alberia. Conheceram-se e se casaram já no Brasil. Além de José Dias, tiveram mais dois filhos - Francisco e Rafael Dias Herrera - e duas filhas - Fuensanta

\footnotetext{
${ }^{84}$ BARBOSA, Gino Caldatto, Santos e seus Arrabaldes - Álbum de Militão Augusto de Azevedo. 2004, passim.
} 
e Maria Dias Herrera ${ }^{85}$. Em São Paulo, para sustentar os filhos, o pai de Herrera trabalhava no polimento de espelhos, utilizando técnicas de espelhamento que trouxe da Espanha.

A família veio se instalar em Santos em 1927, quando Herrera contava sete anos de idade. Ele começou a trabalhar cedo, com dez ou 11 anos.

Como eu era o filho mais velho, o mais responsável, eu tinha que ajudar minha mãe porque o meu pai ficou doente quando eu era criança. Ele teve a gripe espanhola e ficou inutilizado por causa de tanto remédio. Minha mãe costurava para fora, mas não recebia o suficiente. Então, eu tive que trabalhar. ${ }^{86}$

Assim que concluiu o curso primário, na Escola Barão do Rio Branco, a diretora da escola, dona Diva Fialho Duarte, Ihe conseguiu o primeiro emprego, na Casa Lemcke, do qual Herrera lembra com carinho:

Era uma casa alemã de artigos de luxo, enxovais, roupas e tecidos. Minha função era atender aos clientes no balcão e também fazer, de bonde, as entregas em diversos pontos da cidade. Eu até tirava um dinheirinho bom porque os fregueses sempre me davam um trocadinho ou presentinho. ${ }^{8}$

\section{RAYONS IMPRIME! \\ SEDAS MIXTAS! \\ ESTAMOS AFRESENTANDO AS MAIS FECENTES CRRACËES PARA O VERÃO \\ C ASA LEMCKE 45/47 - Jỡ PBSSOA FONE: 2951 - SANTOS}

Anúncio publicado na antiga revista santista Flama, de dezembro de 1943.

\footnotetext{
${ }^{85}$ Atualmente, somente as irmãs estão vivas. Maria, com 80 anos completados em 11 de dezembro de 2007, e Fuensanta, que completou 90 anos em 26 de maio de 2007.

86 Depoimento do fotógrafo. 14/09/2005.

87 Depoimento do fotógrafo. 14/09/2005.
} 
Durante o ano de 1932, Herrera participou da Revolução Constitucionalista. Como outros meninos de sua idade, ele passava de casa em casa, de rua em rua, recolhendo metais para ajudar na fabricação de armas para o esforço de guerra empreendido pelos paulistas contra o golpe de Estado levado a efeito por Getúlio Vargas. Apesar da pouca idade, Herrera compreendeu o espírito da Revolução e colaborou como podia:

Sabe qual era a nossa missão? Juntava cinco ou seis meninos e nós saíamos pelas ruas pra pegar ferro, metais, coisas para fundir e fazer armamento, para ajudar na revolução. A gente via os soldados para lá e para cá e a gente sabia que era para acabar com a ditadura do Getúlio Vargas. ${ }^{88}$

Após o emprego na Casa Lemcke, Herrera trabalhou ainda como vendedor numa sapataria e depois aprendeu o ofício do pai, espelhador, passando a trabalhar na Vidraçaria Casa Verde, a maior de Santos na época, localizada à Rua Amador

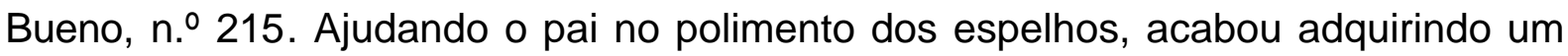
conhecimento que lhe seria útil mais tarde quando, durante a Segunda Guerra, teve que fabricar clichês de vidro para poder fotografar, pois a importação de material fotográfico havia sido interrompida em virtude do bloqueio continental provocado pelo estado de guerra.

Depois disso, Herrera foi trabalhar no Bar da Alfândega, que ficava no terceiro andar da Alfândega do porto de Santos. Ajudava na cozinha lavando louças e preparando pratos simples, servia as mesas e era o entregador de café preferido do inspetor alfandegário da época (1933), Manuel Tavares Guerreiro: "Ele gostava do café bem quente e eu era rápido, descia as escadas correndo para trazer o café

\footnotetext{
${ }^{88}$ Depoimento do fotógrafo. 07/06/2004.
} 
quentinho pra ele"89, lembra Herrera. Em 2004, quando esteve na Alfândega fotografando a inspetora Diva Kodama para uma matéria, contou a ela essa história e a inspetora fez questão de lhe servir, ela mesma, um cafezinho, como que para lhe prestar uma homenagem tardia.

Os primeiros contatos de Herrera com a fotografia aconteceram mesmo no final de 1936, quando começou a trabalhar numa casa de material fotográfico.

Eu vim ao centro fazer alguma coisa e parei em frente à vitrine da Casa de artigos fotográficos, que ficava atrás da prefeitura, na Rua Amador Bueno. Fiquei parado olhando... aí o dono da loja, seo Matheus disse: - O que está olhando aí, menino? Eu disse: - Estou olhando aqui as máquinas. - Você gosta de fotografia? Digo: - gosto. - Estou precisando de um ajudante, você quer vir trabalhar aqui? Eu disse: - vou falar com o meu pai em casa, ver o que ele acha. Então você volta aqui amanhã com a resposta. Falei com o meu pai; disse que o pagamento era mais ou menos o mesmo, mas que lá eu ia aprender um novo ofício e ele disse: - você que sabe, você que escolhe. E eu fui. ${ }^{90}$

Foi nessa loja de artigos fotográficos, a Casa Worisptz, que Herrera começou a sua trajetória no mundo das imagens. Lá ele era laboratorista; aprendeu a mexer com química, a revelar e ampliar. Foi lá também que conheceu dois fotógrafos que prestavam serviço para $A$ Tribuna, para os quais fazia revelações e ampliações: Pedro Peressin Barbado e José Severo Bonfim. Eles o chamaram para ajudar em alguns trabalhos, fazendo fotos em condições totalmente precárias.

Eles me davam uma maquininha caindo aos pedaços e antes de sair para fazer o serviço eu tinha que pegar a máquina, examinar e consertar, colando os pedaços, para não velar. Não era fácil. Além disso, naquela época, a gente tinha que por a máquina no tripé para fotografar na base do magnésio. Não existia lâmpada, flash, não existia nada disso, era tudo na base da explosão. Em alguns locais, se você não tomasse cuidado, você queimava as cortinas... ${ }^{91}$

\footnotetext{
89 Depoimento do fotógrafo. 14/09/2005.

90 Depoimento do fotógrafo. 27/07/2004.

91 Depoimento do fotógrafo. 13/03/2004.
} 
Herrera aprendeu rápido o novo ofício, com o qual se identificou desde o primeiro momento e que o acompanha até hoje. Conforme seus depoimentos, nesse período (final a década de 1930), as técnicas fotográficas utilizadas pelos jornalistas ainda eram rudimentares e a fotografia um ofício artesanal: além do tripé e do flash de magnésio, a máquina não tinha velocidade, era controlada manualmente pelo fotógrafo, que tinha que abrir e fechar com a mão o orifício da câmera, a fim de controlar o tempo de exposição. Só era possível tirar uma foto por vez e, para cada nova foto, era necessário introduzir uma nova chapa no chassi da máquina.

Num dos serviços que prestou para $A$ Tribuna, quando fazia trabalhos avulsos, Herrera teve que acompanhar o dono do periódico Milton Nascimento Júnior numa solenidade especial com um novo avião no aeroclube da Praia Grande. Eles chegaram atrasados, mas Herrera, inconformado, saiu correndo pela pista e conseguiu enquadrar o avião no exato momento em que estava decolando. Nessa ocasião, estava presente o então secretário do jornal O Diário de Santos, Wandick Freitas, que vendo a proeza do jovem fotógrafo imediatamente mandou chamá-lo para contratá-lo.

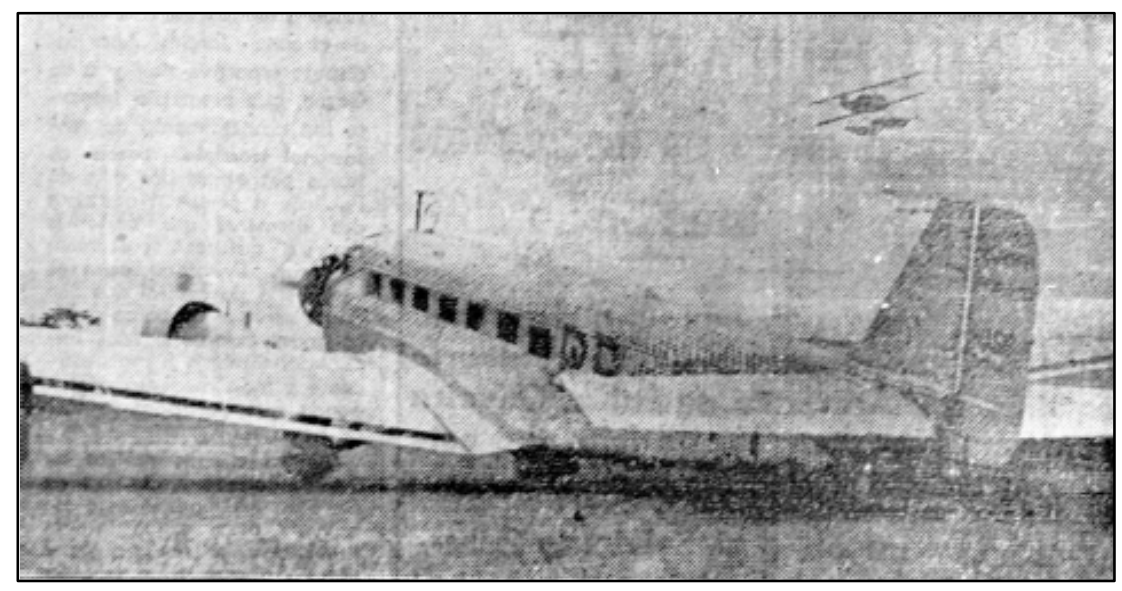

Foto que rendeu a José Herrera o emprego em O Diário 
As vantagens oferecidas pelo Diário, principalmente a carteira de trabalho assinada, convenceram Herrera a aceitar a oferta. Mais tarde, Herrera indicou seu irmão Rafael como fotógrafo para $A$ Tribuna. Rafael era assistente de Herrera no Diário e aprendeu com ele a fotografar. O outro irmão caçula, Francisco (o Paco), acabaria se interessando também por fotografia. Herrera influenciou seus irmãos e os fez apaixonarem-se também pelo ofício de fotógrafo. ${ }^{92}$

Na época, o Diário era o maior concorrente de $A$ Tribuna e é provável que o secretário Wandick tenha "farejado" uma ótima oportunidade na contratação desse jovem e promissor fotógrafo, antecipando-se a qualquer oferta de $A$ Tribuna. Ele foi empregado no dia 4 de setembro de 1937 , recebendo o salário de $\operatorname{CR} \$ 250,00$ (duzentos cinqüenta cruzeiros) por mês. Foi assim que Herrera conseguiu seu primeiro emprego como repórter fotográfico.
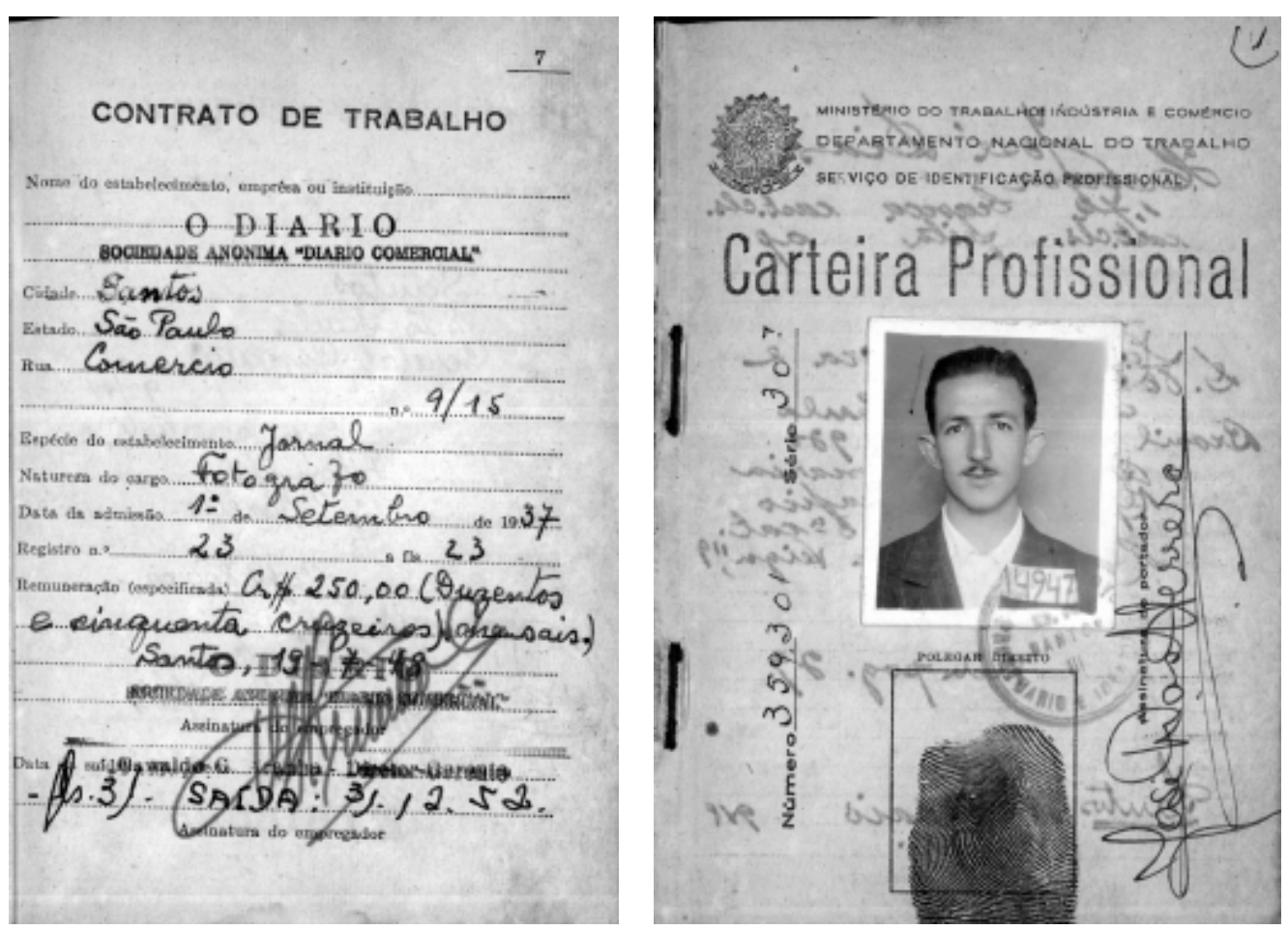

${ }_{92}$ Depoimento do fotógrafo. 14/09/2005. 


\subsection{José Dias Herrera e o fotojornalismo}

No Diário, Herrera tinha que estar disponível para o jornal praticamente das oito horas da manhã à meia-noite. A agitação na redação de um jornal diário refletia bem a dinâmica da cidade na época, logo após o período do apogeu do café. Mesmo com o declínio da cultura cafeeira, o Porto manteve sua importância e os movimentos das categorias de trabalhadores ligados ao Porto se tornavam cada vez mais fortes. $O$ jornalismo ainda não era uma profissão reconhecida e o seu ofício acabava sendo exercido de um modo muito artesanal e na base do improviso. $\mathrm{O}$ depoimento de Herrera sintetiza esse clima geral na passagem dos anos 30 para os anos 40:

Era uma coisa de louco. As máquinas com tripé eram carregadas de um lado para o outro e o fotógrafo depois tinha que revelar e fazer tudo, com chuva ou sol. Mas sempre gostei do correcorre do jornal. Santos era uma agitação constante. A cidade nunca parou. Sempre em transformação. O nível de mobilização política da cidade era inigualável. O Porto era responsável por tudo e considero-o símbolo da cidade por esta razão ${ }^{93}$.

Nessa época, Herrera saía com freqüência em viagem para fazer reportagens nos bairros mais afastados de Santos, como o Marapé e a Ponta da Praia, nos quais não havia serviço de bonde e só se tinha acesso por vias de terra. Fotografou também nos morros santistas: os problemas, a ocupação, as benfeitorias e, principalmente, os deslizamentos $\mathrm{O}$ cotidiano de um jornalista comportava um alto grau de improviso e envolvia riscos. Quando Herrera trabalhou no Diário, não havia sequer uma pauta, como esclarece o fotógrafo:

\footnotetext{
${ }^{93}$ Depoimento do fotógrafo. 30/09/2004.
} 
A gente ficava esperando na redação e assim que era avisado saía correndo pra fazer o assunto. Tudo com muita dificuldade. Não tinha carro próprio, nem ônibus, e em bairros mais distantes o bonde não chegava. Fazer reportagens nos morros era uma aventura. Se você estivesse lá em cima e começasse a chover, você não descia mais. Não tinha rua asfaltada, nem escadas, era muito perigoso ${ }^{94}$.

As viagens para os litorais sul e norte eram feitas de trem, porque ainda não havia estradas. Também não havia hotéis, hospedarias ou restaurantes, e ele tinha que ficar hospedado na casa de algum morador indicado pelo jornal, para realizar a reportagem. Só depois do retorno da viagem era possível fazer a revelação e as ampliações, executadas sempre pelo próprio fotógrafo que, desta forma, era responsável por todas as etapas do processo. A dificuldade de fazer fotos com tripé e flash de magnésio em locais tão inacessíveis era enorme e, por isso, ele se utilizava muito da técnica de fotografar contando somente com a luz natural. ${ }^{95}$

Não tinha estrada e nem condução, só dava pra chegar de trem. $E$, quando chovia, o trem parava e nós tínhamos que procurar alguma casa próxima e esperar a chuva passar. Nós ficávamos hospedados nas casas dos moradores daquelas cidadezinhas, que não tinham nada. Os moradores valorizavam o nosso trabalho porque a gente fazia reportagens sobre as dificuldades deles; as nossas matérias tinham como objetivo melhorar a vida e a condição das pessoas daquele fim de mundo, e elas ficavam agradecidas. Conversavam com a gente, davam alojamento, comida, acompanhavam a alguns lugares [...] O engraçado é que sempre comentavam que, indo pro Litoral, eu comeria bastante banana. Que nada!!! Não existia banana coisa nenhuma. O que tinha estava tudo verde, nunca madura porque eles cortavam tudo para exportar e fornecer para região, nem esperavam amadurecer porque poderia estragar. ${ }^{96}$

Herrera trabalhou cerca de 15 anos no jornal 0 Diário, de 04 de setembro de 1937 a 31 de dezembro de 1952, dividindo a produção das imagens com o fotógrafo Justo Perez, que já atuava no veículo quando ele foi contratado. Nesse jornal,

\footnotetext{
94 Depoimento do fotógrafo. 23/09/2004.

95 Depoimento do fotógrafo. 14/09/2005.

${ }^{96}$ Depoimento do fotógrafo. 14/09/2005.
} 
Herrera fotografava para todas as editorias, mas, principalmente, crimes de morte e acidentes. Como O Diário era um jornal popular, essas matérias ajudavam a vender jornal, e deveriam sair recheadas de fotos.

No Diário, trabalhei pra todas as editorias, pra tudo... Os assuntos relacionados à polícia eram mais comuns. Eu tinha que "fazer" o cadáver, o delegado examinando o cadáver [...], tirava do cadáver sendo carregado, procurava na casa da pessoa que havia sido assassinada uma foto para fazer reprodução e publicar... Era uma trabalheira danada. Se fosse de noite, então, era mais difícil ainda, porque ainda era na base do magnésio. Mas a gente dava um jeito e mesmo que o crime ou acidente tivesse acontecido de madrugada, ainda saía na edição do dia seguinte. Hoje, isso não acontece mais. Acidentes e desabamentos de morros também eu fazia bastante... É que o Diário era um jornal bastante popular, sempre publicava essas matérias mais direcionadas ao povo. ${ }^{97}$

Mal pago, como a maior parte dos jornalistas numa época em que a profissão ainda não era regulamentada, fazia também trabalhos para outros veículos. Mesmo depois de se tornar funcionário de $A$ Tribuna, em $1^{\circ}$ de janeiro de 1953 , continuou fazendo free-lances para O Estado de S. Paulo, Folha de S. Paulo e a Gazeta Esportiva cobrindo eventos esportivos e, principalmente, os jogos do Santos Futebol Clube. Isso, sem contar os trabalhos avulsos fotografando casamentos, batizados e eventos diversos, para os quais era bastante requisitado:

Eu era o preferido das noivas; era muito disputado para fotografar casamentos e festas particulares. Além de já ser conhecido por causa do jornal, eu conseguia convencer os padres a me deixar bater uma a duas fotos dentro da igreja - o que era proibido. O problema era que o magnésio das máquinas fazia uma fumaça danada, que atrapalhava mesmo... Por isso, fotos dentro das igrejas eram proibidas, mas, eu acabava conseguindo... Eu tirava uma foto da noiva entrando, depois outra do casal no altar, e o resto das imagens eu pegava na porta da igreja, no carro, na festa. Eu melhorei de vida com esses serviços. Cobrava bastante dinheiro. ${ }^{98}$

\footnotetext{
${ }_{97}^{97}$ Depoimento do fotógrafo. 14/09/2005.

${ }^{98}$ Depoimento do fotógrafo. 01/03/2006.
} 
No novo emprego (jornal O Diário), Herrera precisava ter uma máquina fotográfica própria. Quem o ajudou nisso foi um amigo: o dono da padaria Suíça (que ainda funciona em Santos), emprestando $\mathrm{CR} \$ 500,00$ (quinhentos cruzeiros) para a compra de uma câmera alemã Voigtländer de fole, tamanho $6 \times 6$ e dotada de duas lentes, que Ihe conferia mais nitidez nas imagens. Tratava-se de um equipamento amador e usado, mas que Ihe servia muito bem. $O$ empréstimo não tardou em ser restituído. Com sua câmera nova, Herrera podia sentir-se, enfim, um repórter-fotográfico completo. Mas sua felicidade durou pouco. Cobrindo um incêndio no centro da cidade, Herrera aproximourse demais do fogo e acabou por perder sua câmera nas chamas. Para continuar trabalhando, arranjou outra máquina emprestada por colegas do jornal até que conseguiu comprar uma nova.

Sua segunda câmera foi uma Speed Graphic de fabricação americana. Ele gostou tanto que posteriormente comprou mais duas da mesma marca, uma delas formato $6 \times 6$ e a outra $9 \times 12 \mathrm{~cm}$. Essas máquinas, apesar de grandes e pesadas, davam fotos de alta qualidade. Produzidas a partir da década de 1940, usavam chapas de vidro e chamavam a atenção pelas enormes lâmpadas tipo bulbo que se queimavam a cada foto. Foram muito utilizadas pelos fotojornalistas durante a Segunda Guerra. Mais tarde, Herrera comprou uma Rolleiflex, máquina alemã mais leve, com a qual trabalhou durante anos e que considera ideal para qualquer tipo de trabalho:

É própria para trabalhar em jornal e fotografar casamentos por causa dos seus negativos grandes, aqueles quadrados, $6 \times 6$. Quando eu preciso de mais esmero, de ampliações maiores, eu uso ela [...] Em casamentos, só usava a Rolleiflex. Ganhei muito dinheiro trabalhando com ela, tenho milhares de negativos. Foi a máquina que mais usei em toda a minha carreira. Hoje, estou com a minha terceira Rolleiflex. ${ }^{99}$

\footnotetext{
${ }^{99}$ Depoimento do fotógrafo. 01/03/2006.
} 
Depois, nos anos de 1980, o fotógrafo adquiriu a máquina japonesa Nikon, da qual teve três. "São excelentes! São aquelas dos negativos mais atuais, 35mm. Hoje, é o modelo que mais uso, principalmente para os serviços particulares". ${ }^{100}$

Do início da carreira, Herrera guarda a lembrança de suas dificuldades:

Eu ia trabalhar de bonde 17 , mas no reboque que era mais barato. $\mathrm{Na}$ frente eram 200 réis e no reboque eram 100 réis. Então a gente ia de reboque, que apesar de jogar mais, era mais arejado e a metade do preço. ${ }^{101}$

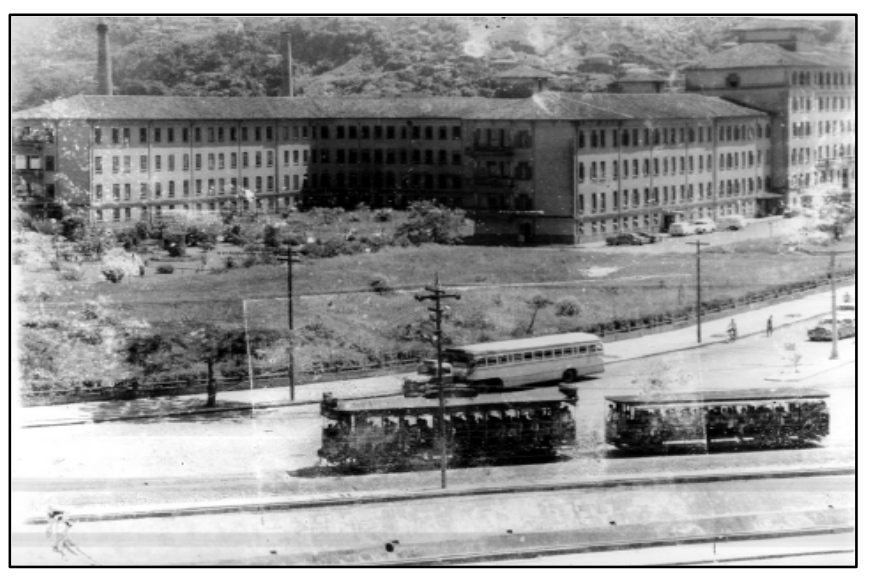

Bonde $n^{\circ}$ 17. Santos, década de 1940. Foto: José Dias Herrera. Acervo FAMS.

Neste mesmo ano de 1937, em que Herrera ingressou no Diário, ocorreu o golpe de Estado comandado por Getúlio Vargas e o início do período de restrição de liberdades, arbitrariedades e torturas do Estado Novo. Os partidos políticos foram proibidos e, em Santos, a Câmara Municipal, já sob intervenção federal desde 1930, foi fechada por prazo indeterminado. ${ }^{102}$ Herrera recorda-se com humor desse

\footnotetext{
${ }^{100}$ Depoimento do fotógrafo. 01/03/2006.

101 Depoimento do fotógrafo. 18/05/2004.

102 SANTOS, Francisco Martins e LICHTI, Fernando Martins, História de Santos - Poliantéia Santista, 1986.
} 
período negro em que a imprensa esteve amordaçada e os jornalistas foram perseguidos:

$\mathrm{Na}$ ditadura de Getúlio Vargas era comum a correria com máquina e tripé nas costas, fugindo dos soldados montados a cavalo. A salvação eram as mulheres que trabalhavam na área do cais (área de prostituição). Elas abriam as portas e o pessoal entrava... Os cavalos não iriam subir as escadas, nem os soldados enfrentar a mulherada. ${ }^{103}$

Porém, faz questão de ressaltar que ele, particularmente, não teve problemas com a Ditadura:

Não sofri nenhuma censura durante a Ditadura. Eu fazia tudo às claras e ninguém se preocupava comigo. Absolutamente, não sofri nada e nunca tive medo de nada. Fui até contratado pelo prefeito general Bandeira Brasil para tirar fotos dos assuntos e das reuniões da Prefeitura. Depois, ele arranjou um fotógrafo oficial para a Prefeitura, o Antonio Nascimento, que ficou no meu lugar como fotógrafo, assessor e mestre de cerimônias, e eu não fiz mais nada [...] Eu sempre trabalhei evitando problemas. Fazia a coisa com jeitinho e da melhor maneira possível. Nunca forcei nada e sabia até onde podia chegar... Por isso, nunca tive problemas e nunca arrumei confusão com a Ditadura. Graças a Deus, eu só era perseguido por mulheres bonitas. ${ }^{104}$

\subsection{A experiência como radialista e o cotidiano durante a Segunda Guerra}

\section{Mundial}

Com a eclosão da Segunda Guerra Mundial, o Porto de Santos ficou praticamente inativo, devido à interrupção dos fluxos comerciais normais entre a Europa e a América do Sul. Internamente, continuava inalterado o estado de exceção instituído com o regime do Estado Novo. Quanto ao conflito mundial, o

\footnotetext{
${ }_{103}$ Depoimento do fotógrafo. 07/11/2006.

${ }^{104}$ Depoimento do fotógrafo. 07/11/2006.
} 
ditador Getúlio Vargas inicialmente declarou o país neutro e só tomou posição em 1943, participando do esforço de guerra e enviando tropas (os "pracinhas" da FEB, Força Expedicionária Brasileira) para combater na Itália.

O foco de interesse da imprensa se deslocou dos temas corriqueiros para os relacionados à guerra. Foi nessa época, que Herrera teve uma curta experiência como speaker narrando boletins diários sobre os últimos acontecimentos da Guerra. Para isso, a Rádio Atlântica ${ }^{105}$ montou um peque no estúdio dentro da redação do Diário. Herrera ainda se lembra da abertura de cada boletim, narrando no estilo típico das transmissões da época, com a fala pontuada pelos erres bem marcados: "PRG5 - Rádio Atlântica de Santos - diretamente da redação do Diário, com noticiário sobre o andamento da guerra na Europa" ${ }^{106}$.

Cabe destacar aqui brevemente que, devido à experiência na Rádio Atlântica, o fotógrafo também fez algumas participações especiais na Rádio Clube de Santos.

Isso foi mais uma brincadeira... Eu tinha amizade com a Rosinha Mastrângelo e ela era uma das pessoas que comandava aquilo. E um dia ela precisou de alguém para fazer o programa e fiz pra ela... Eu fiz comercial, entrevistas e até rádio novela, quando não tinha ninguém para fazer o papel e eu fiz para quebrar o galho. E eu não ganhava nada, era só por amizade mesmo. Quando precisavam me chamavam [...] Eu ia mais por diversão mesmo, mas até que fiz bastante coisa. ${ }^{107}$

Voltando ao período da $2^{a}$ Grande Guerra, enfrentava-se o problema constante do desabastecimento, com falta de alimentos e materiais de consumo,

\footnotetext{
${ }^{105}$ Fundada a 26 de maio de 1935 por Carlos Baccarat, foi a segunda emissora de rádio santista. Durante mais de 30 anos, foi absoluta em audiência, não só em suas radionovelas, como em suas programações esportivas. Em 1971, foi vendida ao grupo A Tribuna e, mais tarde, passou à Élio Ávila de Souza. Atualmente, pertence ao sr. José Manoel Ferreira Gonçalves, que a transferiu para 0 Guarujá. Iniciou com o prefixo PRG-5 e hoje tem o prefixo ZYK-534. Seu principal programa é Deus é Amor.

${ }_{106}$ Depoimento do fotógrafo. 01/03/2006.

107 Depoimento do fotógrafo. 01/03/2006.
} 
principalmente importados, entre eles, filmes e química para revelação das fotos. $\mathrm{O}$ litoral, como região estratégica, estava sujeito a um controle estrito e as casas localizadas próximas à praia tinham de se submeter a um blecaute forçado. ${ }^{108}$ Era proibido acender as luzes e o mesmo acontecia com os bondes que, ao se aproximarem da praia, tinham que desligar os faróis. Os moradores, estrangeiros ou não, necessitavam de um salvo-conduto (carteira pessoal com autorização do delegado da cidade) para poderem entrar ou sair da cidade. Até mesmo para fazer a travessia da balsa entre Santos e Guarujá era preciso apresentar esse salvoconduto para liberar a passagem.

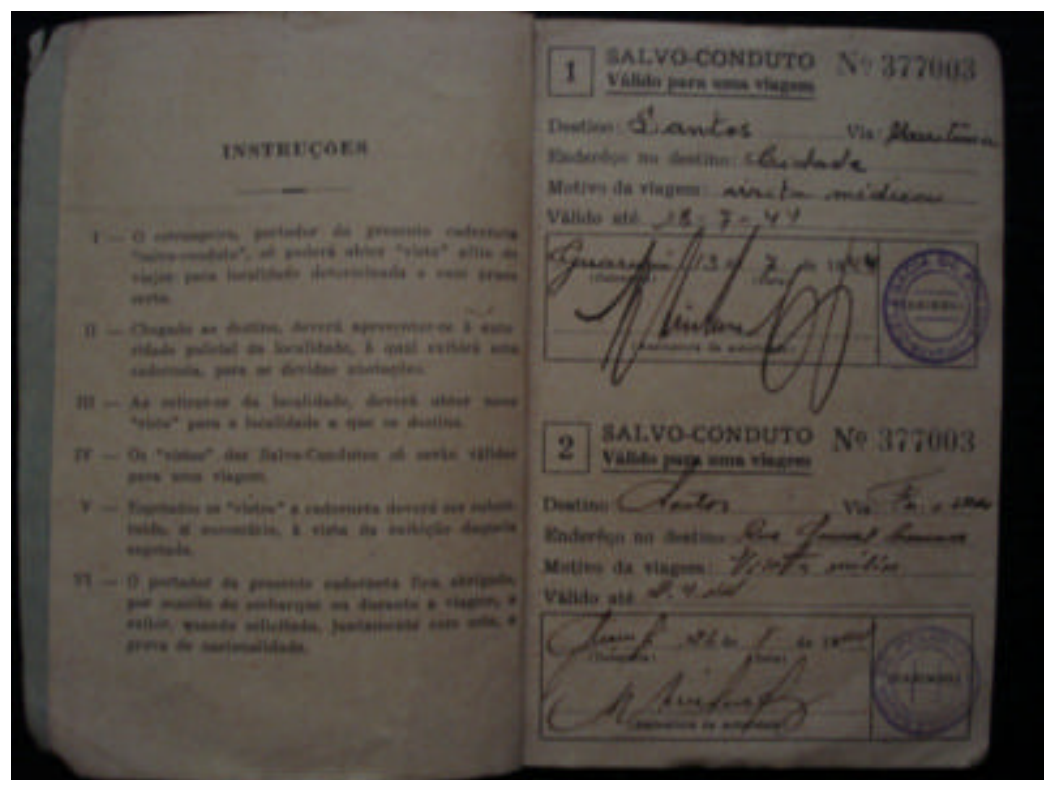

Caderneta de "salvo-conduto"

Em 1939, quando o País ainda era neutro em relação à Guerra, havia atracado no Porto de Santos o transatlântico alemão Windhuck, com 120 tripulantes a bordo. Vindo de um cruzeiro na costa africana, o navio decidiu se refugiar num porto seguro da América do Sul para evitar ser bombardeado, pois foi justamente durante o

\footnotetext{
${ }^{108}$ MARQUES, Nelson Salasar, Imagens de um mundo submerso, 1995, passim.
} 
cruzeiro marítimo que Hitler deflagrou a Guerra com a invasão da Polônia. ${ }^{109}$ No ano seguinte, ficou retido no Porto um outro transatlântico, o italiano Conte Grande, com 200 tripulantes a bordo. Consta que muitos desses tripulantes, impossibilitados de regressar à Europa, se aclimataram ao litoral paulista, tendo sido contratados para trabalhar nos restaurantes, bares e hotéis da Baixada. O primeiro dono do conhecido bar santista Heinz, o "bar alemão", e o dono da cantina vicentina Hirondelle, ainda existentes, estavam entre os passageiros do Windhuck. ${ }^{110}$

Em 1943, porém, quando se iniciou o esforço de guerra, famílias inteiras de japoneses, italianos e alemães foram obrigadas a deixar o litoral rumo ao interior, por serem considerados súditos do "Eixo" e, portanto, suspeitos. Tiveram um prazo de 24 horas para se retirar a uma distância de no mínimo 50 quilômetros do litoral. ${ }^{111}$ As famílias iam embora deixando a maioria de seus pertences para trás. A perseguição aos estrangeiros nesse período foi feroz: qualquer um que fosse visto falando alemão podia ser considerado nazista e muitos foram postos em campos de prisioneiros, montados por Vargas no interior de São Paulo. É provável que muitos dos passageiros dos dois transatlânticos tenham ido parar nesses campos de prisioneiros $^{112}$.

Da época da Guerra, Herrera recorda-se de um fato que aconteceu por ocasião da visita a Santos do poderoso proprietário dos Diários Associados, Assis Chateaubriand. O magnata da imprensa organizou uma solenidade no bairro do Gonzaga, em Santos, para batizar os aviões "Paulistinha"113 fabricados no Brasil,

\footnotetext{
${ }^{109}$ CARVALHO, Beth Capelache de, Uma comunidade rica, que já foi formada por condes e barões, jornal A Tribuna, 01 de agosto de 1982.

110 Cf. a série especial "Rota de Ouro e Prata" em A Tribuna, dias 3, 10, 17, 24 e 31/12/1992.

111 MARQUES, Nelson Salasar, Imagens de um mundo submerso, 1995, passim.

112 Sobre os campos de prisioneiros cf. Marlene de Favéri. Brasil teve 11 campos de concentração, Nossa História, № 21, 2005, p. 66.

113 Avião de dois lugares, asa alta, estrutura de madeira de tubos de aço cromo-molibdênio, empregado largamente no treinamento de pilotos civis pelos aeroclubes. Contava com um motor norte-americano Franklin, de 65 cavalos, e hélices de madeira fabricadas pelo IPT. Era uma aeronave
} 
que seriam enviados à Guerra. Era preciso registrar o evento, mas devido aos problemas de desabastecimento, não existia material fotográfico para comprar. Então, Herrera teve que improvisar e para isso, Ihe valeu a experiência adquirida muitos anos antes com o trabalho na vidraçaria. Comprou uma placa grande de vidro e usando diamante cortou-a em pedaços pequenos, colocou nos chassis e montou ele mesmo umas quinze chapas de vidro para fazer as fotografias. O expediente funcionou e as fotos ficaram ótimas.

Mas, de tudo o que aconteceu durante a Guerra, o fato que Herrera lembra com maior emoção é o desfile em São Paulo, em 1945, quando uma multidão entusiasmada abarrotava as ruas para saudar o retorno dos pracinhas da FEB e comemorar o fim do conflito mundial:

Foi uma coisa fantástica, quando o pelotão começou a desfilar, ainda deu tempo de eu fazer umas duas, três fotos, mas depois a população invadiu e quando eu vi tava enrolado no meio da confusão, todo mundo queria abraçar os pracinhas. Eu tive que fazer o contrário do povo, ir pra mais longe para poder registrar aquele momento de confraternização. Foi inesquecível ${ }^{114}$.

Pelo que constatamos, conforme as entrevistas feitas para esta pesquisa, impressiona na atuação de Herrera sua capacidade de improvisar e lidar com situações adversas. Salta à vista também sua intuição e seu "faro" jornalístico para buscar a notícia onde quer que ela se encontrasse, numa época em que os jornalistas não costumavam trabalhar a partir de pautas predefinidas, mas "faziam" a notícia.

plenamente adaptada às condições brasileiras: robusta, simples, barata, de manejo e manutenção fáceis. Por essas razões, tornou-se um sucesso de vendas. Foram produzidos 777 aviões. Foram exportadas aeronaves para a Argentina, Paraguai, Chile, Uruguai e Portugal.

${ }^{114}$ Depoimento do fotógrafo. 26/10/2004. 
Clóvis Galvão ${ }^{115}$, que trabalhou com José Herrera no jornal $A$ Tribuna, afirma que o fotógrafo nunca desistia de suas fotos:

Ele não era apenas um fotógrafo; era um jornalista completo porque sempre teve senso de notícia e brigava por suas matérias. Herrera sempre foi um profissional incansável, para quem nunca existiu o impossível. ${ }^{116}$

\subsection{O fotógrafo das elites e do povo}

No acervo fotográfico de Herrera, os anos 1940 e 1950 foram particularmente ricos em registros fotográficos de personalidades políticas. Herrera recorda-se que a maior concentração de pessoas que já viu em toda sua vida foi quando Getúlio Vargas apareceu num comício em São Paulo junto com Luiz Carlos Prestes, após ter anistiado o líder comunista. Os dois políticos, anteriormente inimigos, estavam no mesmo palanque e atraíram pessoas de todos os cantos para presenciar este evento singular. Prestes havia sido perseguido e preso pelo governo de Vargas, após a chamada Intentona Comunista (1935). Sua mulher, a militante judia Olga Benário, foi entregue aos nazistas grávida de oito meses pelo chefe da Polícia de Vargas, Felinto Müller, e morreu num campo de concentração.

Chega a ser quase incompreensível a atitude de Prestes, subindo ao palanque lado a lado com o ditador que o encarcerou e condenou sua mulher ao suplício e à morte $^{117}$. Mas nesse dia, apesar da chuva que caía torrencialmente, a multidão

\footnotetext{
${ }^{115}$ Clóvis Galvão trabalha no jornal $A$ Tribuna há 47 anos e atualmente é editor de Opinião. Acompanhou toda a trajetória de José Herrera no jornal.

${ }_{116}$ Depoimento de Clóvis Galvão. 03/02/2007.

117 Sobre a prisão e morte de Olga Benário Cf. MORAIS, Fernando, Olga, 1986.
} 
permanecia de pé, fascinada, espalhada pelas ruas próximas à praça e até por outras praças. Mesmo sem poder vê-los, queriam ao menos ouví-los.

Nesse período, além de Vargas e Prestes, Herrera também fotografou personalidades como Juscelino Kubitschek, João Goulart, Jânio Quadros, Marechal Lott, Charles De Gaulle, o maestro italiano Arturo Toscanini, Cacilda Becker, Adhemar de Barros, entre outros. A presença dessas personalidades em Santos é um bom indicador da importância da cidade no tabuleiro cultural e político nacional e internacional. Afinal, nela se encontrava o maior Porto da América Latina, local de grande importância econômica e estratégica.

No início dos anos 1950, surgiu uma nova oportunidade na carreira de Herrera: ele foi cedido pelo Diário, nos finais de semana, para a revista carioca O Cruzeiro, periódico que se tornou referência em matéria de fotojornalismo, onde trabalhava a célebre dupla Jean Manzon e David Nasser ${ }^{118}$. A reformulação da revista Cruzeiro nos anos 40 foi um divisor de águas na história do fotojornalismo brasileiro. A partir de então, o fotojornalismo passou a ser respeitado e valorizado, principalmente depois da chegada de profissionais estrangeiros que imigraram para o país nessa época, dentre eles se destaca o fotógrafo Jean Manzon ${ }^{119}$.

Herrera tinha que cobrir para a revista os acontecimentos relacionados ao Porto, como as visitas de personalidades, e também os eventos no Grande Hotel do Guarujá que era a sensação do momento, para onde vinham artistas, políticos e celebridades. Toda a alta burguesia da época freqüentava o Grande Hotel, que

\footnotetext{
118 David Nasser foi o repórter mais famoso de seu tempo - entre os anos 1950 e 1970. Escreveu livros de grande repercussão e compôs cerca de 300 músicas, algumas de muito sucesso, como Nêga do Cabelo Duro, Canta Brasil, Confete, Normalista e até a valsa que ainda hoje serve de vinheta para o fim de ano da Rede Globo: Fim de Ano ('Adeus ano velho, feliz ano-novo').

119 "Graças ao Manzon, o fotógrafo brasileiro conquistou um novo lugar. Antes ele era tido como um marginal, que ia para festa de casamento e roubava os presentes. Fotógrafo não usava nem paletó nem gravata. Era um pobre desdentado, o equipamento de péssima qualidade e o salário miserável. O Manzon chegou ao Brasil e moralizou a profissão" (Depoimento de Flávio Damm, apud COSTA, Helouise e SILVA, Renato R. da, A fotografia moderna no Brasil, p. 103-104).
} 
realizava festas e bailes espetaculares. O Grande Hotel também possuía um importante cassino ${ }^{120}$, muito freqüentado até a proibição dos jogos de azar no Brasil em $1946^{121}$. Contratado para cobrir a vida da high society no Guarujá, Herrera pode ter um vislumbre do que era o modo de vida da burguesia que freqüentava o Grande Hotel, impressionando-se com o luxo inacreditável das acomodações e o fausto principesco das refeições. Ele narra como eram seus fins-de-semana no Grande Hotel e confessa que se sentia um "privilegiado":

Havia uma mesa no salão principal, onde eu me sentava com a máquina e esperava as recomendações do gerente. A gente tinha que levar caixas e caixas de lâmpadas para usar a noite inteira, porque cada lâmpada só disparava uma vez ${ }^{122}$. A maioria das pessoas que freqüentava o hotel era de idade, eu era brotinho e tinha muitas meninas que iam para lá e queriam dançar. Não havia quase rapazes, então eu fazia um "sacrifício danado" e entre uma foto e outra, dançava a noite inteira. De manhã, ia para a praia tirar fotos dos banhistas. Eu era um privilegiado ${ }^{123}$.

Perguntado sobre as reportagens desse período que mais o marcaram, Herrera se refere às séries feitas no litoral paulista, antes do processo de expansão urbana, quando pode acompanhar passo a passo à transformação da paisagem litorânea.

No início dos anos 1950, fazer matérias no litoral era uma verdadeira aventura. Para o Litoral Sul e Vale do Ribeira (Mongaguá, Itanhaém, Peruíbe, Itariri, Iguape, Cananéia, Registro) só era possível ir de trem. Não havia estradas: era quase tudo

${ }_{120}$ GIRA UD, Laire José. et alii, Memórias da Hotelaria Santista, 1997, passim.

${ }^{121}$ Após a proibição do jogo no Brasil em 1946, por decreto de Eurico Gaspar Dutra, muitos cassinos foram fechados no país - na época existiam mais de 70 em funcionamento. A proibição do jogo provocou o desespero em quem trabalhava no ramo, desempregou e levou alguns até mesmo ao suicídio. No caso do cassino do Grande Hotel la Plage no Guarujá, houve uma mudança de função na tentativa de evitar o seu fechamento. O cassino passou a ser utilizado para festas, shows e bailes. Mesmo assim, ele não resistiu e foi demolido em 1962. SANTUCCI, Jane. O dia em que as roletas pararam. Revista Nossa História, ํo.35, 2006, pp.36-42.

122 Tratase das lâmpadas tipo bulbo, que se queimavam após serem usadas. Em 1925, o alemão Paul Vierköter inventou o flash de lâmpada. A invenção foi aperfeiçoada por Ostermeier, em 1929, que introduziu um metal refletor na lâmpada. Em pouco tempo, os fotojornalistas adotaram o dispositivo para substituir o flash de magnésio. Cf. SOUSA, Jorge P., Uma história crítica do fotojornalismo ocidental, p. 73. No Brasil, essa e outras técnicas modernas começaram a ser sistematicamente utilizadas somente após a Segunda Guerra.

${ }^{123}$ Depoimento do fotógrafo. 10/11/2005. 
mato. Para fazer as matérias, os jornalistas chegavam a ficar dez dias fora de casa levando "toneladas" de equipamento. Depois, de volta à redação, produziam as reportagens, que iam sendo publicadas paulatinamente. O Litoral Norte era ainda mais inacessível devido à ausência de transporte ferroviário. Nessa época, o lugar mais distante ao qual se conseguia chegar e, assim mesmo, só de avião era a praia de Juquehy. De lá para outras localidades, se chegava somente a pé e com o auxílio de um guia nativo. Até a década de 1960 não havia interligação entre as cidades da Baixada Santista. Na Praia Grande, por exemplo, onde Herrera e o irmão Rafael fizeram várias reportagens, só se chegava pela areia da própria praia. O local era conhecido como "cemitério de automóveis", pois muitos veículos atolavam e com o tempo eram cobertos pela areia, sendo impossível removê-los depois.

Herrera acompanhou todo o processo de construção das duas pistas da Via Anchieta, a primeira inaugurada em 1947 e a segunda em 1953. ${ }^{124}$ Antes, como esclarece o fotógrafo, ainda havia uma estrada de terra (Caminho do Mar) ligando Santos a São Paulo. Quando chovia a estrada ficava escorregadia e havia o perigo de os veículos despencarem pela encosta da serra e quando a terra estava seca, devido ao calor intenso, a passagem dos carros levantava uma nuvem de poeira tão grande que era necessário parar o carro e esperar para evitar o choque com 0 veículo à frente. ${ }^{125}$

\subsection{O trabalho de Herrera em A Tribuna e os "anos de chumbo"}

O diretor de A Tribuna (principal concorrente do Diário), Manuel Nascimento Júnior, fez várias ofertas para tentar contratá-lo. Inicialmente, Herrera não aceitou,

\footnotetext{
${ }_{124}$ MONTEIRO, Paulo Gonzalez, A Conquista da Serra do Mar, 2002, passim.

125 Depoimento do fotógrafo. 10/11/2006.
} 
indicando, em vez disso, seu irmão mais novo, Rafael, também um mestre fotógrafo, que trabalharia por cerca de 50 anos no jornal. Em 1952, após quatro tentativas, Herrera acabou se rendendo aos insistentes convites de Nascimento Júnior e Herrera foi para $A$ Tribuna após ser devidamente registrado e recebendo um salário maior do que o que ganhava no Diário. Além disso, A Tribuna montou um laboratório fotográfico para que Herrera pudesse trabalhar.

Como funcionário de $A$ Tribuna, Herrera registrou acontecimentos que foram decisivos na transformação da vida urbana santista, entre as décadas de 1950 e de 1960: a construção prédio atual da Santa Casa de Misericórdia (reconstruída após um deslizamento no morro) dos dois túneis sob o Monte Serrat (ligando o Centro de Santos às praias, inaugurados respectivamente em 1954 e 1955) e a Cosipa (Companhia Siderúrgica Paulista), de 1953 a 1966. Em 15 de outubro de 1964, o presidente francês Charles De Gaulle veio a Santos para inaugurar a seção de Laminação a Frio da Siderúrgica, construída com tecnologia francesa.

A explosão do Gasômetro (Reservatório de Gás da Cidade de Santos Serviços de Eletricidade e Gás S/A), em 1967, foi uma tragédia que deixou a população em pânico. Herrera morava num bairro próximo ao local da explosão e foi o primeiro jornalista a chegar:

Eu estava dormindo e escutei uma explosão horrível, saí correndo até um ponto de táxi, os motoristas tinham visto de onde tinha vindo o clarão. Fomos para lá. Quando cheguei ainda tinha fogo no local. Depois, fui contratado pela Companhia City, concessionária da empresa de gás, para fazer um levantamento fotográfico aéreo do local atingido pela explosão. Mandaram um helicóptero gigante do Governo Federal. Fiz as fotos com as pernas para fora, sem nenhuma segurança. Mas ficaram ótimas ${ }^{126}$.

${ }^{126}$ Depoimento do fotógrafo. 07/03/2005. 
Foi nessa época também, durante um trabalho particular numa festa de casamento, que Herrera conheceu Ilza Queiroz, sua futura esposa. Após o namoro que durou dois anos, eles se casaram na Igreja da Pompéia, em 27 de maio de 1954. O casamento, simples e só para a família, contou com a presença do excolega do Diário, Saulo Ramos (futuro Ministro da Justiça entre 09/08/1989 e 15/03/1990).

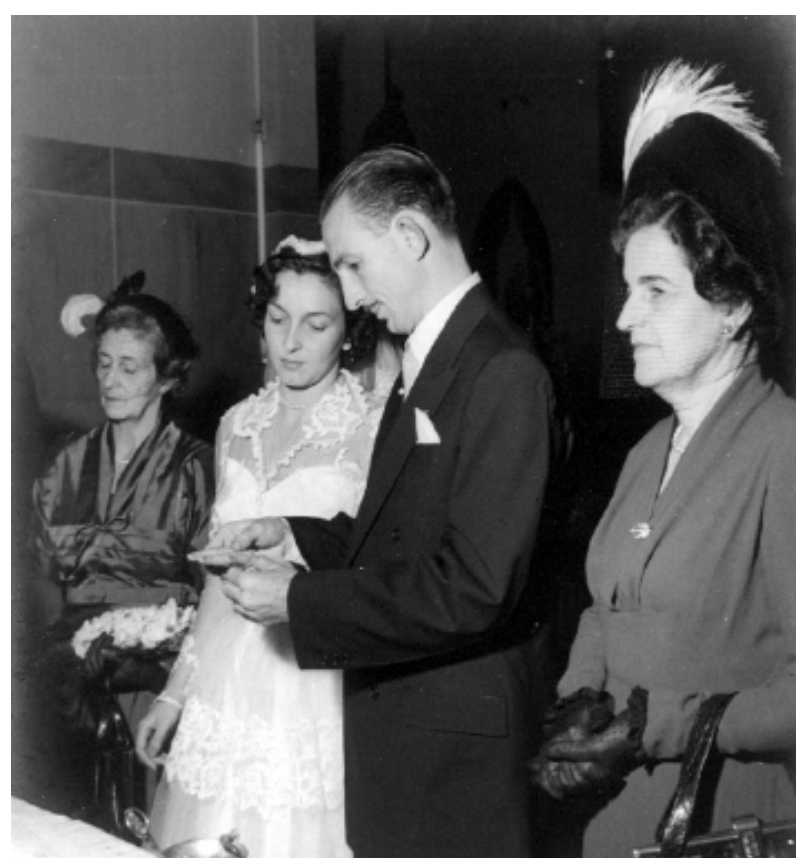

Casamento de José Herrera com Ilza Queiroz. Álbum de família.

Nós tínhamos trabalhado juntos no Diário e temos uma passagem interessante. Ele queria ir trabalhar na Tribuna e o pessoal de lá pediu para ele escrever um artigo. Ele trouxe para eu ler. Eu li. - Meu Deus, que coisa horrorosa!, eu disse para ele. Se você entregar isso aqui, não vai ter nenhuma chance. Vai para casa, pensa melhor, conversa com a tua noiva, que também está começando na carreira de jornalista, e com o pai dela, que é um homem letrado, e melhora isso. Uns quatro dias depois ele voltou com um texto completamente diferente, muito bem escrito. E deu tudo certo para ele. Depois disso ficamos muito amigos. E ele foi o único amigo, que mesmo sem ser convidado (nós só convidamos a família) apareceu na igreja no dia do meu casamento. Eu fiquei muito feliz ${ }^{127}$.

\footnotetext{
${ }^{127}$ Depoimento do fotógrafo. 11/01/2005.
} 
Trabalhando em A Tribuna, Herrera registrou a chegada de Pelé no Santos Futebol Clube em 1956, quando começou sua carreira e ainda não era conhecido por ninguém. No início, Pelé era um jogador tímido, que tinha vergonha de ser fotografado, quase sempre acompanhado pela família. É de Herrera a primeira foto de Pelé vestindo a camisa do Santos, na Vila Belmiro. Apesar de estar fotografando a serviço do jornal, acabou acompanhando Pelé na sua trajetória: foi Herrera quem fotografou o primeiro casamento do craque e as primeiras campanhas publicitárias. É dele a famosa foto com o Pelé, que foi utilizada para uma campanha da Coca-Cola na década de 1970. Herrera registrou a fase de ouro do time santista e acompanhou a ascensão de Pelé, com fotos que se tornaram antológicas.

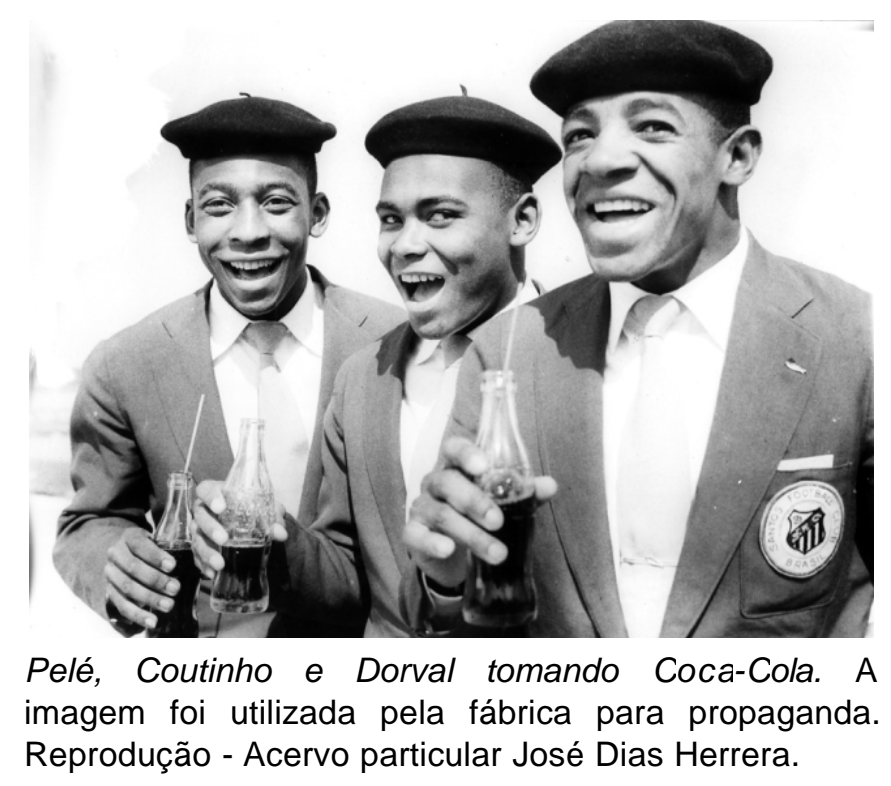

Nessa época, era difícil exercer o ofício de jornalista. As principais dificuldades eram de natureza material. Os jornalistas ganhavam salário mínimo, não havia garantias, nem estabilidade. Porém, apesar desses inconvenientes, o jornalismo era também um ofício mais romântico e mais criativo do que hoje. Perseguia-se o furo de reportagem. Não havia pauta: o jornalista "fabricava" a notícia. 
Em 1961, houve uma greve histórica dos jornalistas que mudou o modo de pensar da categoria e também a atitude dos donos de jornais em relação a esses profissionais. $^{128}$ Foi a partir desse momento, que começou a haver uma maior valorização da profissão. O jornal Última $\mathrm{Hora}^{129}$, idealizado e comandado pelo jornalista Samuel Wainer, na década de 1950, foi um marco em todo esse processo. O diário foi pioneiro na forma de utilizar a fotografia, no uso de cores, na elaboração das primeiras páginas e também na difusão das edições regionais, antecipando o formato dos jornais atuais. Wainer também se destacou pela coragem e ousadia em criar um jornal independente das tradicionais dinastias familiares que até hoje dominam os meios de comunicação no Brasil. Sua iniciativa foi determinante na valorização do ofício do jornalista ${ }^{130}$.

Foi nessa época, que o jornalista Lauro Tubino ${ }^{131}$ tornou-se colega de Herrera na redação de $A$ Tribuna. Em seu depoimento, ele nos trouxe valiosas informações sobre a trajetória de Herrera e também sobre a história da imprensa em Santos. Tubino chegou em Santos em 1961, vindo do interior do Rio Grande do Sul. Sua primeira experiência como jornalista foi no Última Hora. Já a partir de 1962, passou para A Tribuna, época em que Giusfredo Santini, o "chefe da dinastia dos Santini", era diretor do jornal. Diretor do Caderno de Turismo do jornal $A$ Tribuna durante 29 anos, ele observa que a época da Ditadura "foi muito difícil para todos nós: para

\footnotetext{
128 Jornal dos Jornalistas no. 273, abril de 2005. (Nas lutas específicas da categoria, o Sindicato foi responsável pela organização de uma greve histórica de 1961, totalmente vitoriosa, que conquistou o primeiro piso salarial para uma categoria profissional no país e a jornada de cinco horas).

${ }^{29}$ O jornal Última Hora, diário e vespertino, foi um marco na história do jornalismo brasileiro. Fundado pelo jornalista Samuel Wainer em 12 de junho de 1951, refletiu em suas páginas a conturbada situação política do Brasil e do mundo nas décadas de 1950 a 1970. Representou uma revolução político-cultural e editorial em seu meio. Em 1971, o jornal foi vendido a um grupo empresarial liderado por Maurício Nunes de Alencar. De 1973 até 1987, a responsabilidade pela edição passou à Arca Editora S.A. Após ser vendido ao empresário José Nunes Filho, a Última Hora encerrou definitivamente suas atividades em 26 de julho de 1991, quando teve sua falência decretada pela Justiça, devido a uma dívida que chegava a 450 milhões de cruzeiros.

${ }^{130}$ Cf. sobre o Última Hora e a trajetória de seu fundador, cf. o relato autobiográfico de Samuel Wainer, Minha razão de viver, 1998.

${ }^{131}$ Lauro Tubino trabalhou no jornal A Tribuna de 1961 até 2001. Foi criador e editor do caderno de Turismo e atuou ao lado de José Herrera durante 15 anos.
} 
quem fotografava, para quem escrevia; nós enfrentamos o problema da censura. Nós simplesmente não publicávamos matérias, deixávamos em branco". ${ }^{132}$

Havia sempre um funcionário do governo (o censor) na redação fazendo pesquisa e o editor era obrigado a colocar toda informação que tivesse à sua disposição. $O$ marido de Patrícia Galvão ${ }^{133}$ (Pagu), Geraldo Ferraz, era secretário de redação e a própria Pagu chegou a trabalhar em $A$ Tribuna. O Última Hora era um jornal mais populista, que satisfazia os anseios dos trabalhadores; já $A$ Tribuna era um jornal "extremamente conservador": Havia também os jornais A Hora Santista, com um perfil mais apelativo, sensacionalista, principalmente por causa da cobertura de crimes, além do Diário, dos Diários Associados, de Assis Chateaubriand.

Lauro Tubino nos contou um pouco sobre todo o clima que precedeu o golpe militar de 1964, a politização dos movimentos sociais em Santos e denuncia hoje o intuito sistemático de ocultar a memória desse período.

Nós éramos, nessa época, senão a mais politizada, ao menos uma das cidades mais politizadas do país. Porque as grandes decisões nacionais em termos trabalhistas eram tomadas aqui pela grande liderança que estava radicada em Santos ${ }^{134}$.

A força das categorias vinculadas ao cais e ao sistema de transportes era fundamental para o sucesso de uma greve. As grandes lideranças sindicais de Santos se concentravam num órgão que se chamava Fórum Sindical de Debates, FSD. ${ }^{135}$ Era ele que tomava as decisões e convocava as greves. Contudo, após 1964, houve um processo de desmonte do movimento sindical e de apagamento da memória das lutas. O sindicalismo santista era a grande força nacional. Os

\footnotetext{
132 Depoimento de Lauro Tubino. 15/08/2006.

133 Patrícia Rehder Galvão (1910-1962), mais conhecida como Pagu, foi uma escritora e jornalista santista. Participou do movimento modernista em São Paulo, ao lado de Oswald de Andrade. Também foi agitadora e militante comunista, tendo sido presa e torturada pelo regime de Vargas. ${ }_{134}$ Depoimento de Lauro Tubino. 15/08/2006.

135 SILVA, Ricardo M. da, Sombras sobre Santos: o longo caminho de volta, 1988, passim.
} 
jornalistas de $A$ Tribuna acompanharam as intervenções e as prisões. Faziam plantão na porta da Capitania dos Portos e nos quartéis do Exército para saber quem tinha sido preso, como esclarece o jornalista:

Foi uma época muito difícil, muito delicada, principalmente porque você vivia num estado de exceção, não havia garantia nenhuma. A cidade pagou por ter sido considerada a Moscou do Brasil... ela passou por um castigo do governo federal... ela só começou a se reerguer de uns doze anos para cá. ${ }^{136}$

Santos era uma cidade de perfil cosmopolita, muitas pessoas chegavam a vir de São Paulo para usufruir da vida noturna de Santos, tida como mais barata e mais tranqüila que a da capital. Mas Santos sofreu um acentuado processo de declínio de sua vida urbana durante o período da ditadura militar, declínio do qual vem se recuperando nos últimos anos, com os planos de revitalização do centro da Cidade.

Um ano que ficou gravado na memória dos santistas foi 1964, quando aportou no estuário o navio-presídio Raul Soares. Mais do que um local improvisado como presídio, era um aviso e uma afronta àqueles que pensassem em se opor ao poder militar. ${ }^{137}$ Flutuando ameaçador no cais, bem próximo do centro de Santos, e cheio de presos políticos, o chamado "navio do medo" podia ser visto por todos os que por ali passavam diariamente. Herrera conta que não teve problemas para fotografar os presos do Raul Soares. Foram os próprios militares que chamaram a imprensa, para atestar que os presos estariam sendo bem tratados:

Arrumaram tudo, esperando a gente chegar no Raul Soares, os presos estavam no convés para ser fotografados, muitos reclamavam para a gente, mas a gente não podia fazer nada. Fotografei e fui embora. ${ }^{138}$

\footnotetext{
${ }_{136}$ Depoimento de Lauro Tubino. 15/08/2006.

137 MELO, Lídia Maria de, Raul Soares, um navio tatuado em nós, 1995, passim.

${ }^{138}$ Depoimento do fotógrafo. 21/08/2006.
} 
Antes de 1964, Santos era uma cidade cuja base da economia era o Porto e a exportação de café. A ascensão da cidade ocorreu juntamente com a ascensão do movimento de trabalhadores mais bem organizado do País. A vitalidade de sua vida urbana se devia ao poder de compra desses trabalhadores, que possuíam um alto potencial reivindicativo. Com a política de arrocho salarial dos militares, a renda da classe trabalhadora e sua força de mobilização declinaram. Da década de 1990 para cá, o porto se segmentou e se automatizou, dispensando mão-de-obra em massa. Seguindo as políticas neoliberais impostas pelo FMI e o Banco Mundial, os principais terminais foram privatizados, o Porto foi separado da Cidade. Cada empresa passou a contratar por conta própria seu grupo de trabalhadores, terceirizando serviços. ${ }^{139}$

\subsection{O fotógrafo de ontem e de hoje}

Em atividade há 70 anos, José Herrera acompanhou a evolução da imprensa e de seus profissionais, mas acredita que, com o passar dos anos, o trabalho foi perdendo o seu valor e encanto, tanto para o contratado como para o contratante dos serviços, e ressalta que, quando começou a fotografar para veículos da imprensa, sempre lhe exigiram profissionalismo:

Eu precisava provar todo dia que era bom, não existia uma foto impossível pra mim. Eu tinha que seguir um estilo jornalístico diferente para cada assunto. Hoje, não existe mais esse tipo de cobrança. Antigamente, tirávamos foto de tudo, tínhamos que estar em todos os lugares, tínhamos que produzir sempre fotos atuais... Era trabalho duro mesmo. Hoje, tiram uma foto rapidinho ou até usam imagem de arquivo.

\footnotetext{
${ }^{139}$ RODRIGUES, José e PÁSCOAL, José, Porto de Santos - Uma década de transformações (19901999), 2001, passim.
} 
Herrera revela também que o trabalho de um fotógrafo ia muito além do simples ato de fotografar. Muitas vezes, ele próprio precisava se pautar:

Eu chegava na redação, pegava a maquininha e saía pras ruas atrás de assunto, de algum acontecimento que pudesse dar matéria. Eu fotografava buraco de rua, poste de iluminação quebrado, acidentes, brigas; o que aparecesse na minha frente. Daí, eu mesmo pegava as informações, o contato das fontes e voltava para redação para entregar para o secretário (atual chefe de redação). Tinha dias que eu ia e voltava da redação várias vezes [...] Ou também eu estava sozinho na redação, tocava o telefone lá no jornal e informavam alguma coisa: um incêndio no cais, por exemplo. Eu saía correndo, tirava as fotos, anotava os dados que eu conseguia na hora, passava para o papel e entregava para o secretário. Naquela época nem tinha pauteiro, não tinha ninguém... ${ }^{140}$

E completa:

Eu fazia tudo: tirava a foto, voltava para o laboratório do próprio jornal para revelar, pendurava o filme para secar... e isso era demorado, levava mais de uma hora. Enquanto o filme secava, eu saía novamente para fotografar mais coisa. Daí, eu chegava e escolhia quais as imagens mais interessantes para ampliar. Eu ampliava umas três ou quatro e levava para o secretário escolher. As ampliações variavam de tamanho: uma coluna, duas colunas, três colunas, conforme o secretário pedia.... Mas eu sempre sabia, mais ou menos, o tamanho certo, porque eu sabia o tamanho da matéria e calculava... Outra coisa importante é que era eu que comprava todo o material: as drogas, o filme. Eu comprava em São Paulo, pegava a nota e o jornal me reembolsava. O laboratório do jornal também era de minha total responsabilidade, até a limpeza. ${ }^{141}$

Além de toda a dedicação ao trabalho, José Herrera também era um excelente colega de trabalho, sempre muito ético e disposto a ajudar os companheiros. Para o jornalista Hamleto Rosato ${ }^{142}$, Herrera é um exemplo a ser seguido, "pois nunca se

\footnotetext{
${ }_{140}^{140}$ Depoimento do fotógrafo. 01/03/2006.

141 Depoimento do fotógrafo. 01/03/2006.

142 Hamleto Rosato trabalha no jornal $A$ Tribuna desde a década de 1950 até hoje. Foi o criador do suplemento infanto-juvenil $A$ Tribuninha, o primeiro da América Latina.
} 
deixou corromper por nada ou ninguém, e nem produzia imagens que pudessem desmoralizar ou humilhar uma pessoa". ${ }^{143}$

A jornalista Miriam Guedes $^{144}$, que também atuou ao lado de Herrera, destaca toda a experiência do fotógrafo:

Quando cheguei na Tribuna, o Zé já estava e ele era considerado o "anjo da guarda" dos focas (jornalistas iniciantes) porque ajudava-os a fazer as matérias e a entrevistar as pessoas, sempre dando toques do que estava faltando, do que era preciso perguntar e anotar. Eu, que cobria setores ligados à economia, gostava muito de sair com ele para as coberturas porque me passava segurança e ele era mestre em abrir todas as portas, mesmo aquelas dos empresários mais resistentes a lidar com a imprensa. O Zé ia chegando muito simpático e alegre, conhecia porteiros e secretárias pelo nome e, quando a gente via, já estava diante do entrevistado. Feitas as principais perguntas, algumas vezes escapava uma informação importante, ou por falta de experiência, ou por preocupação com a entrevista de um modo geral. Era quando o Zé exercia toda a sua gentileza e elegância dando os toques certos, sempre no melhor momento, até que a entrevista ficasse completa e sem falhas. ${ }^{145}$

E relembra de uma das muitas demonstrações de companheirismo do colega:

Zé também era um excelente companheiro de viagem. Em uma oportunidade em que formos ao interior de São Paulo, para Águas de Lindóia, fazer matérias para o caderno de Turismo, o motorista ficou doente na volta e o Zé tomou o volante trazendo o carro do jornal até Santos, com a mesma tranquilidade com que se comportava no dia-a-dia da redação. Os dias longe da família também não eram monótonos porque ele tinha sempre uma boa história de experiências anteriores para contar. Assim, ia ensinando a gente, jovens repórteres, a suportar com calma e alegria as agruras da profissão. Sempre sem demonstrar que estava ensinando. ${ }^{146}$

\footnotetext{
${ }^{143}$ Depoimento de Hamleto Rosato. 25/08/2007.

${ }^{144}$ Miriam Guedes trabalhou no jornal A Tribuna de janeiro de 1968 a junho de 2001. Foi repórter, repórter especial, sub-chefe de reportagem, chefe de reportagem, $3^{3}$ editora, $2^{2}$ editora e editorachefe do jornal. Atuou ao lado de José Herrera durante oito anos.

145 Depoimento de Miriam Guedes. 05/04/2007.

${ }^{146}$ Depoimento de Miriam Guedes. 05/04/2007.
} 


\subsection{A família e as recompensas da profissão}

Como irmão mais velho entre os homens e consciente da sua importância no sustento da família, José Herrera sempre foi muito dedicado e preocupado com os pais e irmãos. Por isso, começou a trabalhar tão cedo. ${ }^{147}$ Segundo a irmã mais nova, Maria $^{148}$, "Herrera sempre foi o pai dos irmãos; sempre esteve presente quando precisaram dele, desde novinho". ${ }^{149}$ Fuensanta ${ }^{150}$, a irmã mais velha, lembra que 0 fotógrafo chegou a largar os estudos para trabalhar. "Ele tinha consciência da situação da nossa família; ninguém precisou obrigá-lo a arranjar emprego, ele foi por conta própria". ${ }^{151}$

Sobre o abandono da escola, Herrera comenta:

Eu parei de estudar na quarta série, com uns 10 anos. Eu tirei diploma do curso primário na escola Barão do Rio Branco, no Campo Grande. Daí pra frente, foi trabalhar. Eu até queria continuar estudando, mas não dava porque eu tinha que ajudar a minha mãe a sustentar a família. Eu pensava que nunca seria ninguém porque eu não tinha estudo. Mas, daí, eu conheci a fotografia, comecei a estudar sobre o assunto por conta própria, comprava livros, aprendia a mexer nas câmeras... Nunca tive professor. Felizmente comecei a ganhar dinheiro, a melhorar de vida.

Além de ajudar no sustento da família desde cedo, a fotografia também se transformou no trabalho dos irmãos mais novos de Herrera, Rafael e Francisco (o Paco), que aprenderam o ofício com o irmão mais velho. Os três chegaram a trabalhar juntos por diversas vezes. Infelizmente, somente José Dias Herrera permanece vivo. "Dos homens, eu era o mais velho. Eles eram bonitos, fortes; eu

\footnotetext{
${ }^{147}$ Conforme já citado no início deste capítulo, José Herrera começou a trabalhar com pouco mais de dez anos.

${ }_{148}$ Maria Dias Herrera completou 80 anos em dezembro de 2007.

149 Depoimento de Maria Dias Herrera. 01/09/2007.

${ }_{151}$ Fuensanta Herrera completou 90 anos em maio de 2007.

151 Depoimento de Fuensanta Herrera. 01/09/2007.

152 Depoimento do fotógrafo. 14/09/2005.
} 
era o mais franzino, mais feinho, mais desajeitado. E, no fim, sou o único vivo. É a vida, né?". 153

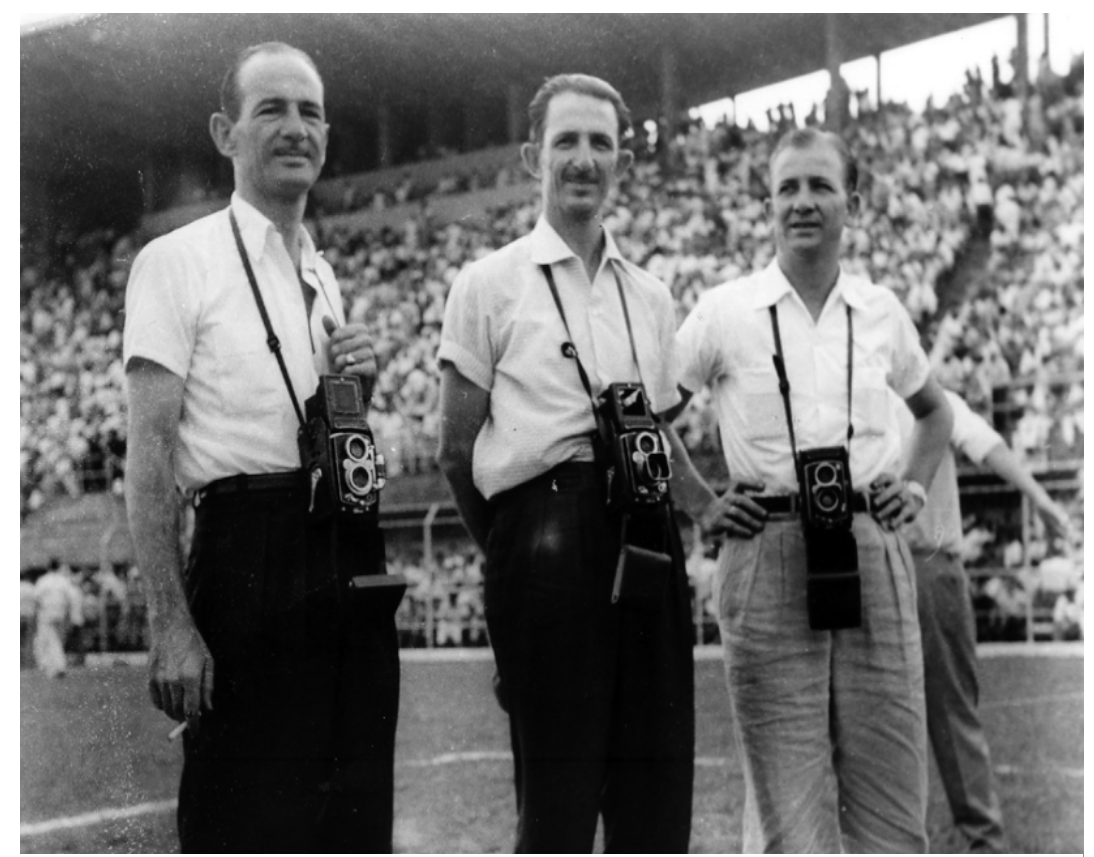

Os irmãos Francisco (Paco), José e Rafael Herrera cobrindo um jogo do Santos Futebol Clube. Na época, Paco era assistente de Herrera no jornal $O$ Diário e Rafael trabalhava para o jornal $A$ Tribuna. Álbum de família.

Realmente, José Herrera só tem a agradecer à fotografia que, segundo ele próprio, Ihe proporcionou tudo o que tem hoje.

Conheci lugares, pessoas e até a minha esposa, que eu conheci quando fotografava um casamento... E já são mais de 50 anos de casado... E, claro! Ganhei dinheiro, sustentei a minha família, criei as minhas duas filhas... Construí a minha vida com a fotografia, né? Veja bem, quando eu cheguei de São Paulo, com sete anos, minha família não tinha nada; nós viemos para morar num porão da casa de um parente, dormíamos em um colchão no chão. Hoje, moro num apartamento de três banheiros, de frente à praia, num dos melhores bairros de Santos, no $13^{\circ}$ andar. E conquistei tudo isso com a fotografia, sozinho. Nem a minha esposa precisou trabalhar. ${ }^{154}$

\footnotetext{
${ }_{153}$ Depoimento do fotógrafo. 14/09/2005.

${ }^{154}$ Depoimento do fotógrafo. 14/09/2005.
} 


\subsection{Herrera, memória viva da cidade de Santos.}

A partir da segunda Guerra Mundial, o fotojornalista tornourse fundamental ${ }^{155}$. A fotografia era um atestado de que um determinado evento havia acontecido, porque saía documentado. A imagem não era apenas uma ilustração que acompanhava a notícia, ela é que dava credibilidade ao que estava sendo escrito. Segundo o depoimento do jornalista Hamleto Rosato, em Santos, nenhuma solenidade começava antes de Herrera chegar.

As fotos que Herrera fez do Santos Futebol Clube, entre as décadas de 1950 e de 1970 e, principalmente, as fotos de Pelé, tornaram seu nome conhecido. Em 2002, foi organizada sob a curadoria do francês Romeric Buel e patrocínio da CocaCola a exposição "Pelé - A Arte do Rei", na qual as fotografias de Herrera, tiradas no começo da carreira de Pelé era a principal atração. A exposição itinerante percorreu várias cidades do Brasil e do exterior, incluindo Paris. Neste mesmo ano, a fotografia de Herrera foi destaque na revista Fotografe Melhor, principal publicação especializada da área no país e que também circula na Europa.

Em 9 de dezembro de 2003, Herrera recebeu o título de "Cidadão Emérito" de Santos. Ainda em 2003, foi homenageado também pela Câmara dos Deputados de São Paulo. O Memorial das Conquistas do Santos Futebol Clube, em 2004, realizou a exposição "Nas Lentes de Herrera", com as principais fotos que Herrera fez do time para A Tribuna. Ainda em 2004, o fotógrafo foi homenageado na exposição

\footnotetext{
${ }^{155}$ A presença sistemática dos fotógrafos nos acontecimentos públicos os tornaram mais respeitados pelos políticos, artistas e figuras públicas em geral. "Consta mesmo que o ministro britânico dos negócios estrangeiros, no início de uma reunião intergovernamental, teria perguntado, com certo humor: - 'Onde está o doutor Salomon?' Não podemos começar sem ele, pois o público pensará que este encontro não teve importância. E o Primeiro Ministro prussiano, Otto Braun, terá dito também que: 'hoje pode ter-se uma conferência sem ministros, mas não sem o doutor Solomon'". Cf. Jorge Pedro Sousa, Uma história crítica do fotojornalismo ocidental, pág. 77-79. Erich Salomon pode ser considerado o precursor do fotojornalismo. É com ele que nasce a chamada Candid Photograph, a fotografia não posada, não protocolar que visa captar a verdadeira personalidade das figuras públicas no seu cotidiano.
} 
"FotoSantos", realizada na Pinacoteca Benedito Calixto de Santos. Em 2007, foi inaugurada no shopping Parque Balneário, por iniciativa da Prefeitura de Santos, a exposição “José Dias Herrera: mais de 70 anos de fotografia”. A obra de José Dias Herrera e sua importância para a história da cidade de Santos e dos santistas começam a ser reconhecidas e valorizadas no cenário nacional e internacional.

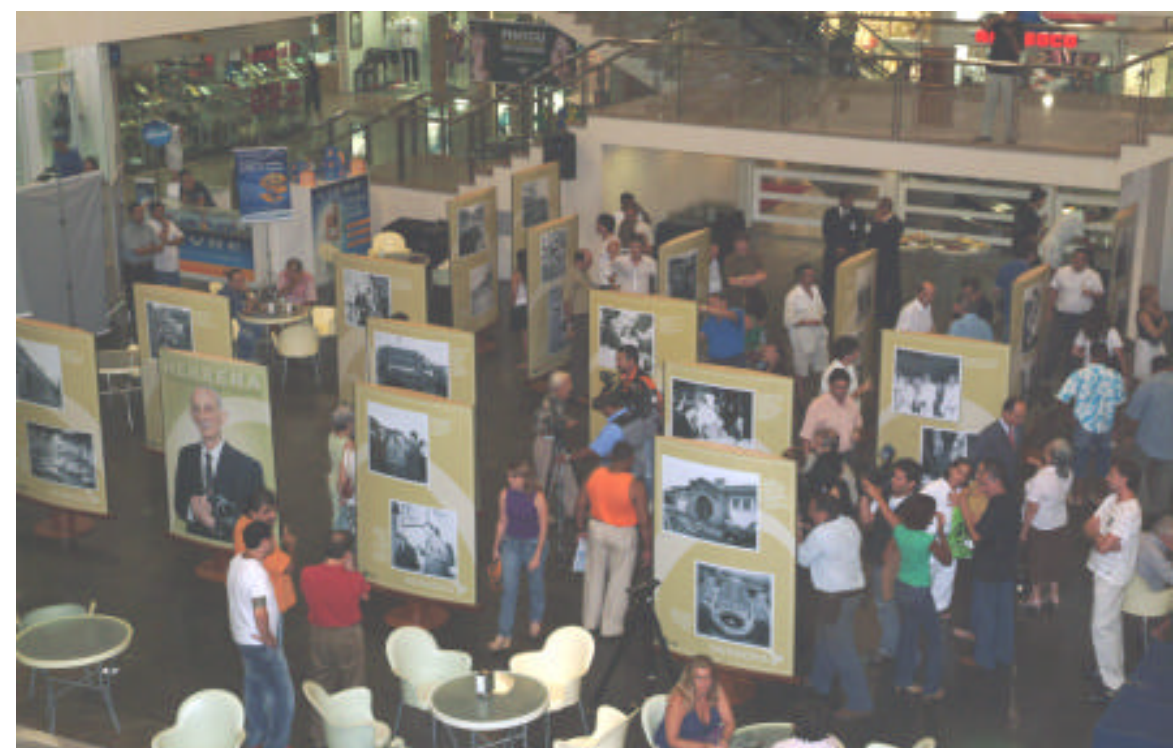

Exposição "José Dias Herrera: mais de 70 anos de fotografia", inaugurada no Shopping Parque Balneário. Foto: Antonio Vargas

Felizmente, Herrera preservou uma parte do acervo fotográfico dos veículos para os quais trabalhou, guardando os negativos. Outra parte se encontra na Associação Comercial de Santos, ainda sem organização, catalogação e identificação. No que diz respeito ao jornal $A$ Tribuna, a maior parte do acervo foi descartada com o tempo, incluindo as chapas de vidro utilizadas por Herrera na época da Segunda Guerra. Como ressalta o jornalista Lauro Tubino, "houve um desmonte da memória da Tribuna", o pouco que se preservou se deve aos acervos deixados por Herrera e seu irmão, Rafael.

José Herrera saiu da Tribuna em meados da década de 1970 e, depois de uma rápida passagem pela Prodesan, assumiu o cargo de jornalista na Prefeitura 
Municipal de Santos, a 05 de agosto de 1987, recebendo um salário de Cz $\$ \$^{156}$ 16.512. Passou a atuar como repórter-fotográfico na Secretaria de Comunicação de Santos (Secom), onde permanece até hoje. Todos os dias, ele chega pontualmente às oito da manhã, pega sua pauta e sai para as ruas para mais um dia de fotografia. Declara que só pára quando morrer e continua a fazer belas fotos, escolhendo sempre os melhores ângulos. Depois de muita resistência, acabou concordando em fazer seu trabalho na secretaria com uma máquina digital, embora para os trabalhos particulares, que nunca deixou de fazer mesmo na época em que trabalhava nos jornais, utilize a máquina analógica, com a qual tem mais familiaridade e confia mais:

Só uso a digital no serviço, pra fazer meus trabalhos particulares prefiro a Nikon, essa maquininha que eu já tenho há um tempão. Com ela eu me sinto mais dono da foto. Você coloca o filme, dá a abertura de diafragma, controla a velocidade, tudo da tua cabeça. Você está sabendo o que está fazendo, qual o resultado que pretende obter. Com a digital não precisa nem ser fotógrafo, já vem tudo definido lá dentro e, pior, depois tudo pode ser modificado no computador. Tira e põe cor, "melhora" aqui e ali, faz o que quiser. Dá até para trocar a noiva da foto depois do casamento. Hoje, você não pode garantir a veracidade das fotos. As fotos digitais não valem mais como documento, não dá mais pra afirmar nem que o que aparece na foto estava presente no acontecimento fotografado. Uma loucura... não dá mais para confiar. ${ }^{157}$

Nesse ponto da conversa, tocamos justamente numa questão delicada, que atravessa todas as discussões nos últimos tempos sobre o caráter icônico da imagem fotográfica e sua função de testemunho da realidade: até que ponto podemos considerar a foto como um documento, ou seja, como uma prova definitiva de que um fato ou evento realmente aconteceu? As tecnologias digitais, ao permitirem a manipulação quase total da imagem, colocam em cheque essa idéia.

\footnotetext{
${ }^{156}$ Cruzados - moeda da época.

157 Depoimento de fotógrafo. 01/03/2006.
} 
Em atuação desde 1937, Herrera tem hoje (2007) 87 anos de idade, sendo 70 dedicados à profissão. Ele é, possivelmente, o mais antigo fotojornalista em atividade no Brasil. Mestre do ofício, Herrera costuma declarar aos repórteres que o procuram para fazer matérias sobre ele que, para fotografar é preciso, principalmente e acima de tudo, uma sensibilidade apurada: "Quem fotografa uma vez, não pode e não quer mais parar. Eu fotografo quase todos os dias este espetáculo vivo da natureza. E ele sempre é diferente, a cada dia” ${ }^{\text {"158. }}$.

José Dias Herrera, a "memória viva da cidade", já documentou até agora mais de 70 anos de vida da cidade, sua história e suas transformações. Herrera foi um fotógrafo autodidata, aprendeu a profissão na prática e no cotidiano dos jornais e das ruas. Ele fotografou a vida da cidade de Santos e a sua própria vida foi inteiramente dedicada à paixão pela fotografia: "Quero morrer nas ruas, trabalhando, fotografando, porque é isso que eu sei fazer. Essa é a minha vida". ${ }^{159}$

\footnotetext{
${ }^{158}$ Depoimento de fotógrafo, $11 / 03 / 2006$.

${ }^{159}$ Depoimento do fotógrafo, 16/03/2004.
} 


\section{CAPÍTULO 3}

\section{Santos, uma história em imagens}

Este capítulo foi reservado para as análises iconográficas de imagens representativas dos diversos períodos e temas retratados por José Herrera durante a sua trajetória profissional e abordados no texto dos capítulos anteriores. Para a produção de cada ficha, foram selecionadas entre duas e quatro imagens de um mesmo assunto, porém, somente uma fotografia foi analisada. Ao todo, são 125 imagens apresentadas e 50 analisadas.

Os fichamentos foram agrupados por temas e constituem uma amostra ampla e significativa de toda a produção de Herrera. Levou-se em conta, na seleção das imagens, tanto a relevância do assunto retratado no contexto da história da cidade, quanto o seu valor estético. Aqui, realizamos, além da análise externa e contextual da imagem, uma análise interna que permitiu uma apreciação mais aprofundada dos elementos presentes nas imagens, trabalhando em conjunto imagens, entrevistas com o fotógrafo e pesquisas em livros e jornais. Além da identificação e contextualização histórica das fotografias, também serão ressaltadas opiniões e reflexões do fotógrafo.

Temas como o Porto, Carnaval e Pelé mereceram um item específico devido à sua importância do tema e à quantidade de material encontrado. 


\subsection{Urbanismo}

Segundo a historiadora Wilma Therezinha, a expansão urbana de Santos teve início por volta de 1870, com a ocupação do Centro da Cidade, que logo ficou adensado, obrigando a população a avançar em direção ao Valongo e ao Paquetá. Mais tarde, esses bairros também declinaram como área residencial.

Espalhadas em terrenos próximos às praias, as chácaras e sítios começaram a aparecer dando origem aos bairros da orla, como Gonzaga, Boqueirão e José Menino. Com o tempo, essas construções cederam lugar às mansões. Os moradores mais modestos se fixaram em bangalôs e chalés de madeira nas áreas mais distantes, formando bairros como Vila Belmiro, Campo Grande, Jabaquara e Macuco. A Ponta da Praia foi o último bairro da orla a ser ocupado e a Zona Noroeste, a última área a ser urbanizada.

A crise de 1930 destruiu fortunas. As mansões da praia foram vendidas e transformadas em hotéis. Com a inauguração da Via Anchieta, em 1947, a função de veraneio da Cidade se acentuou e acelerourse o processo de transformação arquitetônica com a crescente construção de edifícios tipo arranha-céus ou espigões. As casas e casarões começaram a desaparecer. ${ }^{160}$

Nos últimos 70 anos, todo o processo de mudanças, desenvolvimento e modernização urbanística de Santos foi fotografado por José Dias Herrera, desde a inauguração da Via Anchieta até o surgimento dos grandes prédios de apartamento, passando pela abertura de ruas e avenidas, construções de praças e monumentos, as inaugurações dos túneis do Centro, do Emissário etc.

\footnotetext{
${ }^{160}$ ANDRADE, Wilma Therezinha F. de, Santos - um encontro com a História e a Geografia, p.66, 68 e 69.
} 


\subsection{1 - TÚNEL RUBENS FERREIRA MARTINS}

Assim denominado pela lei 2.756, de 11 de novembro de 1963, em homenagem a um antigo prefeito santista que abraçou a causa de sua construção, o Túnel Rubens Ferreira Martins é um dos mais movimentados eixos de trânsito da cidade de Santos entre o Centro e os bairros situados na orla, até a divisa com São Vicente, e os canais 1 e 2. A Companhia de Engenharia de Tráfego (CET) calcula que atualmente cerca de 3.500 veículos circulem por hora apenas pela Waldemar Leão, rua que dá acesso aos túneis. ${ }^{161}$

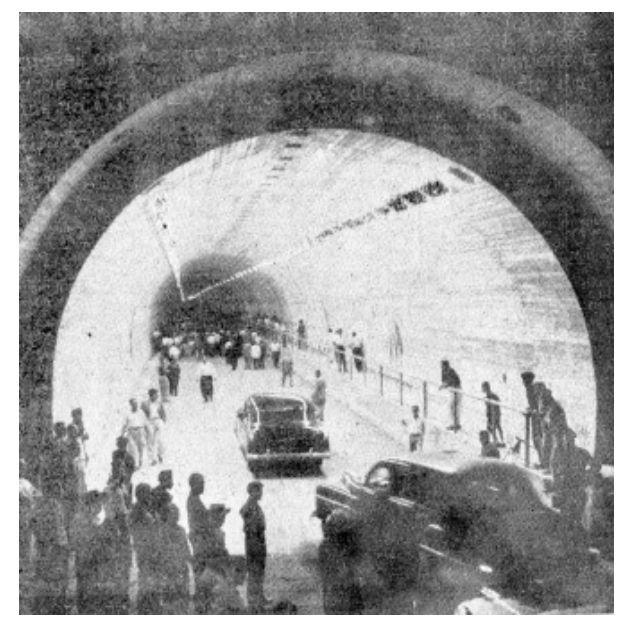

Inauguração da segunda pista do Túnel Rubens Ferreira Martins. Santos. 23 de dezembro de 1955. Reprodução do jornal A Tribuna.

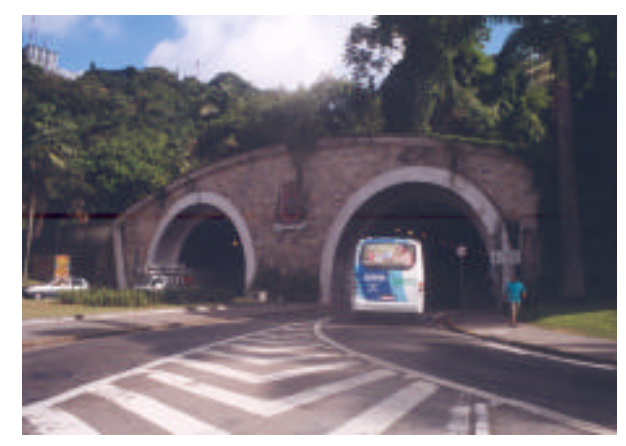

As duas pistas do Túnel Rubens Ferreira Martins. Santos. 14 de fevereiro de 2007. Gelatina/prata, $35 \mathrm{~mm}, \quad 10 \times 15 \mathrm{~cm}$. Acervo particular José Dias Herrera.

${ }^{161}$ Túnel será totalmente recuperado. Diário Oficial de Santos. 24 de maio de 2006, p.06. 


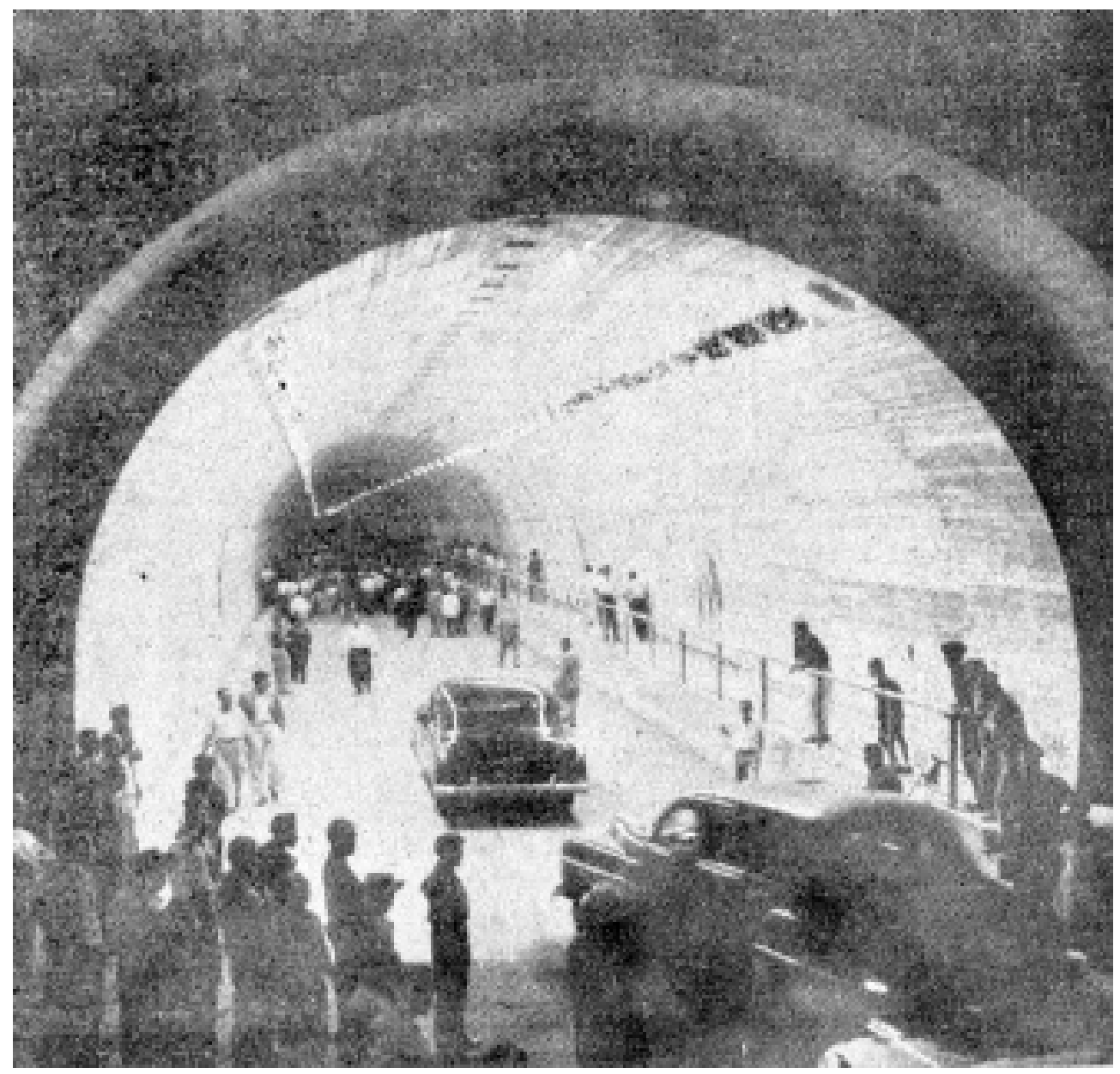

Inauguração, em 23 de dezembro de 1955, da segunda pista do Túnel Rubens Ferreira Martins e da iluminação local pelo prefeito Antonio Feliciano da Silva.

Como podemos ver na imagem, houve solenidade festiva com cortejo de carros dos convidados e uma grande passeata da população. O carro que se vê à frente da comitiva é do prefeito. O túnel foi escavado sob o Monte Serrat com o objetivo de ligar a região central de Santos ao bairro do Jabaquara e daí às praias. José Herrera comenta sobre a construção dos túneis:

Os túneis começaram a ser construídos muito tempo antes da inauguração. As obras demoraram muito e não ficaram os dois túneis prontos juntos... Mas foi muito bom para Cidade, foi um grande melhoramento, valeu a pena esperar. Facilitou a vida de todo mundo, a população ficou muito satisfeita. ${ }^{162}$

162 Depoimento do fotógrafo. 13/03/2006. 
O túnel começou a ser construído em 22 de dezembro de 1949, durante a administração do prefeito Rubens Ferreira Martins. Os serviços foram executados pelo Departamento de Estradas e Rodagem (DER), também responsável pelo projeto. O cronograma inicial de dois anos de duração não pôde ser cumprido, devido a problemas financeiros - os custos foram considerados elevados para a época. A primeira pista do túnel foi inaugurada no dia 6 de setembro de $1954^{163}$ e a segunda um ano depois, em 23 de dezembro de 1955, ambas na gestão do prefeito Anto nio Feliciano ${ }^{164}$.

${ }^{163}$ Entregue ao trânsito, na manhã de ontem, a primeira via do túnel do Monte Serrat. $A$ Tribuna. Santos. 07 de setembro de 1954, p.24.

${ }_{164}$ Iluminados, com luz fluorescente, foram entregues ontem os dois túneis. A Tribuna. 24 de dezembro de 1955, p.16. 


\subsection{2 - AVENIDA ANA COSTA}

Considerada uma das principais e mais movimentadas vias de Santos, a Avenida Ana Costa concentra uma grande variedade de atividades e tem à sua volta os mais tradicionais bairros de Santos, como a Vila Mathias e o Gonzaga. Reunindo inúmeros estabelecimentos comerciais, escritórios empresariais, entidades de classes, unidades escolares, clínicas, igrejas, bancos, bares e restaurantes, apresenta um interessante contraste arquitetônico, evidenciado pela mistura das antigas construções e dos modernos edifícios nela encontrados.

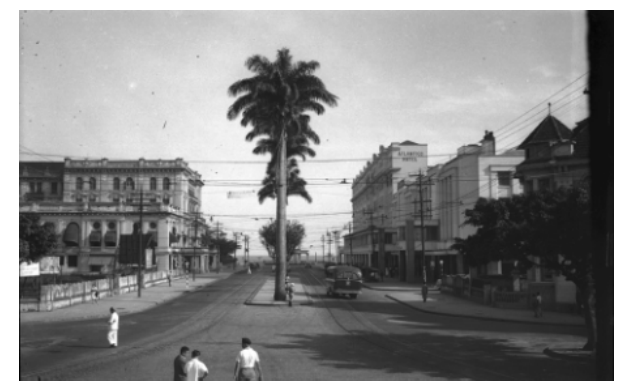

Avenida Ana Costa. Foto tirada em direção à praia. Santos. 1937. Gelatina /prata, $6 \times 9 \mathrm{~cm}$. Acervo FAMS.

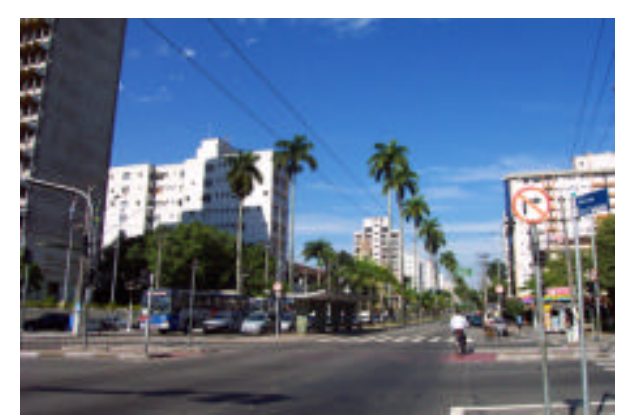

Cruzamento das avenidas Francisco Glicério e Ana Costa, onde se pode observar as palmeiras no canteiro central. Foto tirada em direção à praia. Santos. 12 de julho de 2005. Imagem digital. Acervo Secretaria de Comunicação de Santos. 


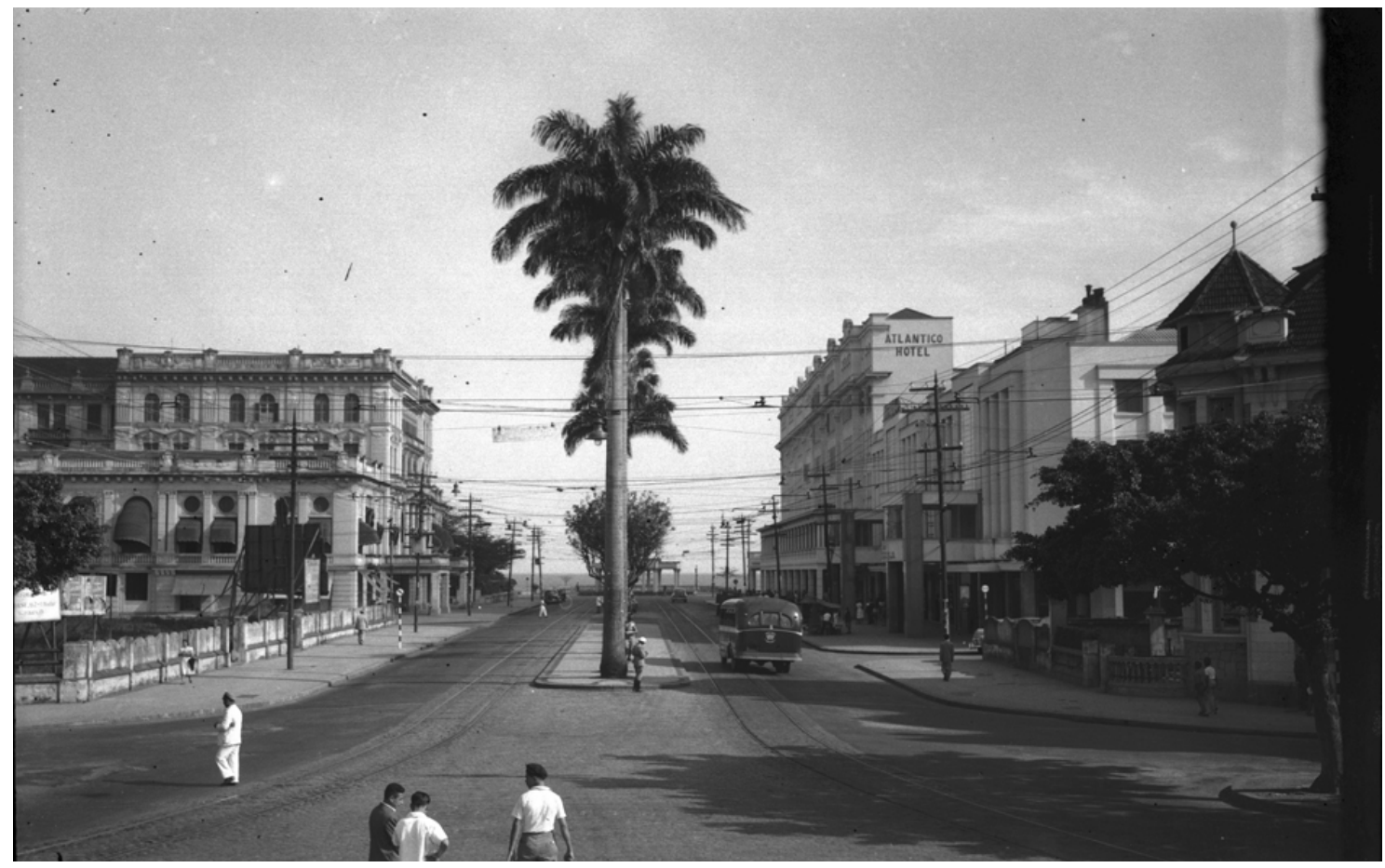

Trecho final da Avenida Ana Costa, em foto tirada do alto do Monumento aos Andradas, na Praça Independência, no sentido da praia, no ano de 1937.

Como podemos observar na foto, à esquerda, está o antigo prédio do Parque Balneário Hotel e, à direita, o edifício que abrigava o Atlântico Hotel e o Cine Teatro Casino (sic) Atlântico, cujo teto móvel se abria nos dias de calor. Mais tarde, o complexo Atlântico virou Cine Gonzaga. Atualmente, só existe o hotel, na esquina com a avenida da praia, que está bastante modificado. O espaço que abrigava o cassino é ocupado por uma loja de departamentos, uma lanchonete, uma farmácia e uma livraria. Ao centro, a fileira de Palmeiras Imperiais que estão presentes em toda a extensão da avenida.

Para José Herrera, a avenida Ana Costa é a mais conhecida dos santistas: "É, sem dúvida, a avenida mais famosa da Cidade. Impossível quem não conheça a Ana Costa... Ela é bastante movimentada, tem tudo... É larga, bonita. Gosto muito das suas palmeiras". 165

${ }^{165}$ Depoimento do fotógrafo. 13/03/2006. 
Conforme o semanário Boqueirão News, a Avenida Ana Costa, que também é conhecida como Avenida das Palmeiras por ter dispostas ao longo do seu canteiro central cerca de 130 palmeiras imperiais, recebeu esta denominação no ano de 1887 em homenagem à dona Ana Costa, esposa de Mathias Casimiro Alberto da Costa, fundador do bairro da Vila Mathias e o responsável pela abertura do corredor viário. O nome só foi oficializado a 16 de fevereiro de $1921 .{ }^{166}$

Além disso, Fernando Lichti explica que a Avenida Ana Costa foi a primeira via de Santos a receber iluminação pública elétrica, inaugurada na noite de 15 de agosto de 1903, no trecho entre o ponto de bondes da Vila Mathias e a Rua Carvalho de Mendonça, e teve as suas primeiras obras de asfaltamento iniciadas em 30 de junho de 1914, no trecho entre a Avenida Rangel Pestana e a Rua Carvalho de Mendonça. ${ }^{167}$

\footnotetext{
${ }_{167}^{166}$ A Avenida Ana Costa. Almanaque Santista. Boqueirão News. Santos, fevereiro de 2000, p.04.

${ }^{167}$ LICHTI, Fernando Martins, História de Santos - Poliantéia Santista, 1996, p.44.
} 


\subsection{3 - PRAÇA INDEPENDÊNCIA}

A Praça Independência foi oficializada pela Lei. №. 647, de 16 de fevereiro de 1921 , sancionada pelo prefeito Coronel Joaquim Montenegro, e entrou em vigor a $1^{\circ}$ de janeiro de 1922. A pedra fundamental do Monumento aos Andradas, localizado no centro da praça, foi colocada em 22 de agosto de 1921, durante solenidade prestigiada pelo então presidente da República, Dr. Epitácio Pessoa. A sua inauguração aconteceu em 7 de setembro de 1922, com a presença do governador Washington Luís, como ato saliente das comemorações do Centenário da Independência. Antes da construção da praça, o local abrigava uma chácara. ${ }^{168} \mathrm{Um}$ dos principais e mais famosos logradouros da cidade de Santos, a Praça Independência está localizada no coração do bairro do Gonzaga.

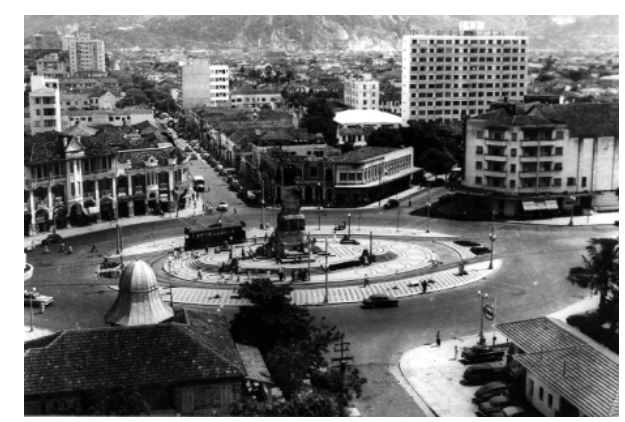

Praça Independência. Gonzaga, Santos. 1963. Gelatina/prata, $6 \times 9 \mathrm{~cm}$. Acervo FAMS.

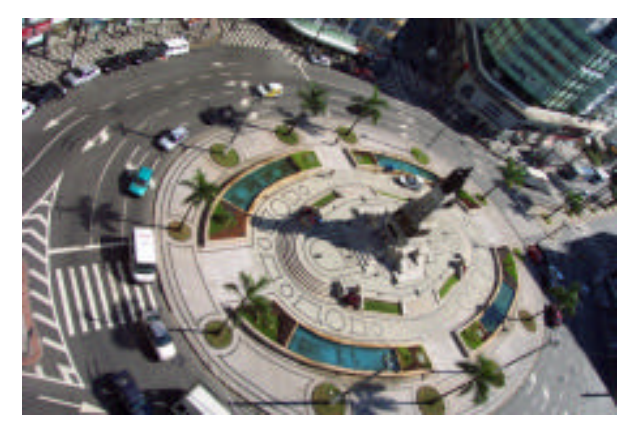

Praça Independência. Aniversário do Gairro Gonzaga, Santos. 14 de junto de 2005. Imagem digital. AcervoSecom.

$\overline{168}$ RODRIGUES Olao, Veja Santos. 1975, p. 309. 


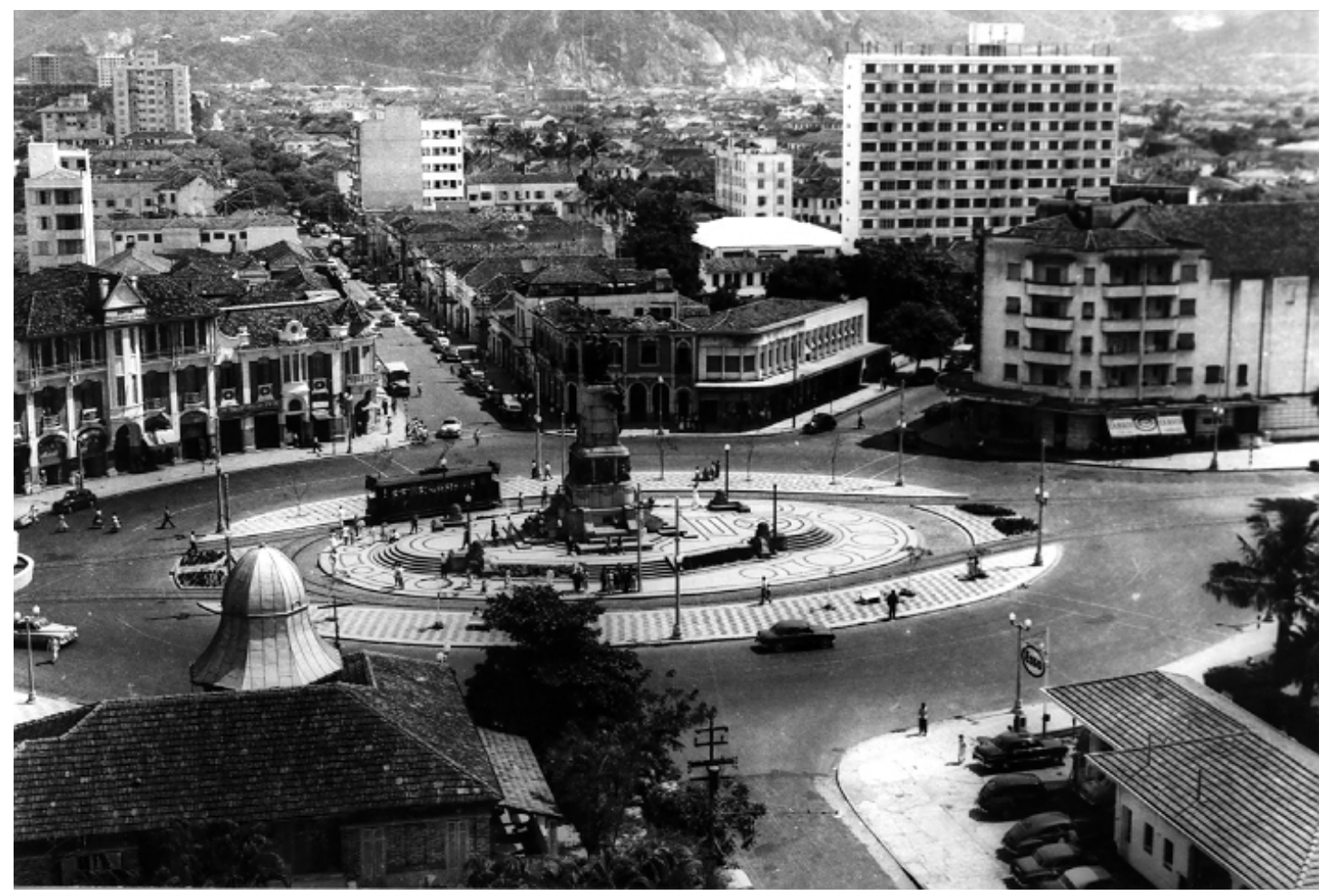

Praça Independência no ano de 1963.

Na foto, a rua que se vê acima, mais à esquerda, é a Marechal Floriano Peixoto. Na sua esquina, à esquerda, o prédio do antigo Restaurante São Paulo, que permanecia lotado até de madrugada e que teve sua porta estragada por nunca ser fechada. Na esquina, à direita, o edifício José Maria D’Almeida, construído a partir de 1958.

A próxima rua, acima à direita, é a Marechal Deodoro da Fonseca. Na esquina, à esquerda, o antigo edifício Aurora, construído a partir de 1959. À direita, também fazendo esquina com a Avenida Ana Costa, o Cine Atlântico e o Bar Regina, que era ponto de encontro de artistas, jornalistas e boêmios da época. Por lá, era comum ver Tanah Corrêa, Patrícia Galvão, Jonas Mello, Ney Latorraca, Geraldo Ferraz, Plínio Marcos e outros. O posto Esso aparece na esquina da praça com a Rua Galeão Carvalhal e é o único estabelecimento retratado que ainda existe. No canto esquerdo da foto, na parte de baixo, o telhado de um casarão encobre a esquina da 
Rua Goitacazes, onde funcionava a Viação Cometa e as pessoas esperavam os ônibus que partiam a todo momento para São Paulo.

De formato oval, a Praça Independência tinha o calçamento de ladrilho hidráulico e abrigava pontos de paradas de bondes à sua volta. Por isso, era cortada por duas linhas.

Ao centro, destaque para o Monumento aos Andradas, o maior da cidade de Santos. De autoria do escultor Antonio Sartori, a obra, que é toda em granito, com figuras e ornamentos em bronze, destaca os elementos étnicos que formam o povo brasileiro e os fatos primordiais da Independência. Nele, os irmãos Andradas estão trajados de acordo com os cargos que cada um ocupava na época da Proclamação: José Bonifácio com a farda de Ministro do Reino e Estrangeiros, Martim Francisco com o uniforme de coronel de engenheiros e Antonio Carlos com a toga de magistrado. ${ }^{169}$

Para José Herrera, a Praça Independência é um dos mais famosos logradouros da Cidade e um dos pontos mais significativos de Santos:

Antigamente qualquer movimentação acontecia lá: comemorações de datas cívicas, festas esportivas, manifestações populares, encontros religiosos e até o Carnaval. As manifestações políticas aconteciam mais no Centro, na Praça da República. ${ }^{170}$

Atualmente, a Praça aglutina intenso comércio ao seu redor e é palco, principalmente, de manifestações políticas e esportivas. O fotógrafo também lembra das transformações ocorridas no logradouro:

Hoje, a única coisa que resiste é o posto de gasolina da esquina. $\mathrm{O}$ resto não tem mais. Nem o ponto dos bondes, nem 0

\footnotetext{
169 BREFE, Ana Cláudia Fonseca, O Monumento aos Andradas, 2005, p.73.

170 Depoimento do fotógrafo. 03/03/2006.
} 
cinema... Agora, a praça parece menor, não sei por que... Os espelhos d'água de hoje não existiam. Mas, com toda transformação, eu continuo gostando muito da Praça Independência. ${ }^{17}$

A última obra para a revitalização da Praça Independência aconteceu no ano 2000 e o Diário Oficial de Santos destacou, em 02 de setembro, data da entrega do local, as transformações ocorridas, confirmando, inclusive, a construção dos espelhos d'água citados por Herrera.

[...] @ 15 postes que viabilizavam a passagem dos trólebus foram substituídos por apenas cinco, que agora sustentam a rede com menor poluição visual [...] As 15 palmeiras da espécie conhecida popularmente como 'Areca de Locuba', que não faziam parte do projeto original da praça, foram transferidas para o jardim da praia do Embaré. Em volta do Monumento aos Irmãos Andradas foram criados quatro espelhos d' água servidos por fontes [...] oito refletores de 400 watts foram instalados no solo para valorizar e destacar o monumento.

\footnotetext{
$\overline{171}$ Depoimento do fotógrafo. 03/03/2006.

172 Praça da Independência é entregue hoje à população. Diário Oficial de Santos. 02 de setembro de 2000, p.4.
} 


\subsection{4 - ARRANHA-CÉUS}

Abordando a questão das moradias, na década de 1940 tem início a passagem do uso das casas e chácaras para os edifícios de apartamentos, que logo se transformam em uma muralha em frente às praias santistas. Os prédios são construídos obedecendo à uma arquitetura mais preocupada com a solidez do que com a estética: aparência sólida, materiais resistentes, custo baixo, racionalidade na planta, acrescida da meta capitalista do lucro. Assim, explica-se a uniformidade dos edifícios que dominam as faixas praieiras da Cidade. ${ }^{173}$

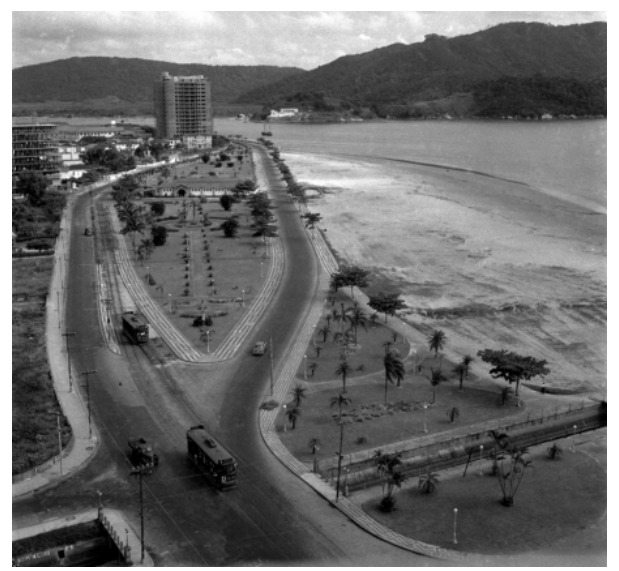

Edifício Enseada, o primeiro prédio na orla ca Ponta da Praia, ainda em construção. Foi projetado pelo autodidata João Artacho Jurado, responsável por obras que se tornaram referência em Santos e São Paulo. Santos. Década de 1950. Gelatina/prata, 9x6cm. Acervo José Dias Herrera.

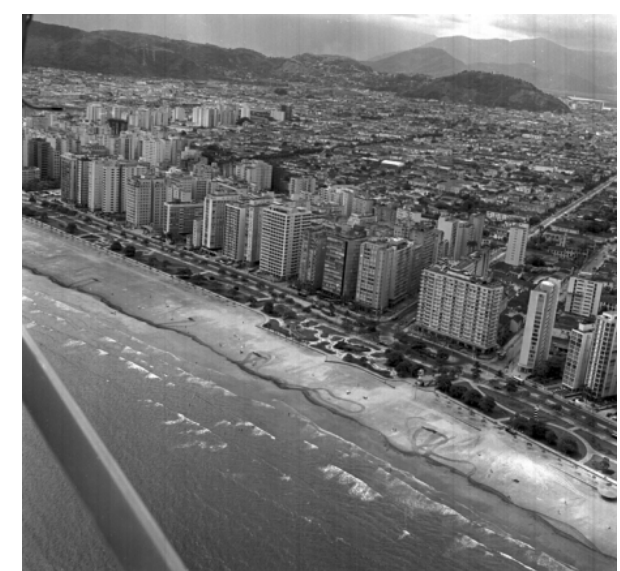

Vista panorâmica da orla praiana no trecho do bairro do Boqueirão, em frente à Av. Conselheiro Nébias. Santos. Década de 1970. Gelatina/prata, $6 \times 9 \mathrm{~cm}$. Acervo FAMS.

\footnotetext{
${ }^{173}$ ANDRADE, Wilma Therezinha F., Presença da Engenharia e Arquitetura - Baixada Santista, 2005 p. 84 et seq.
} 


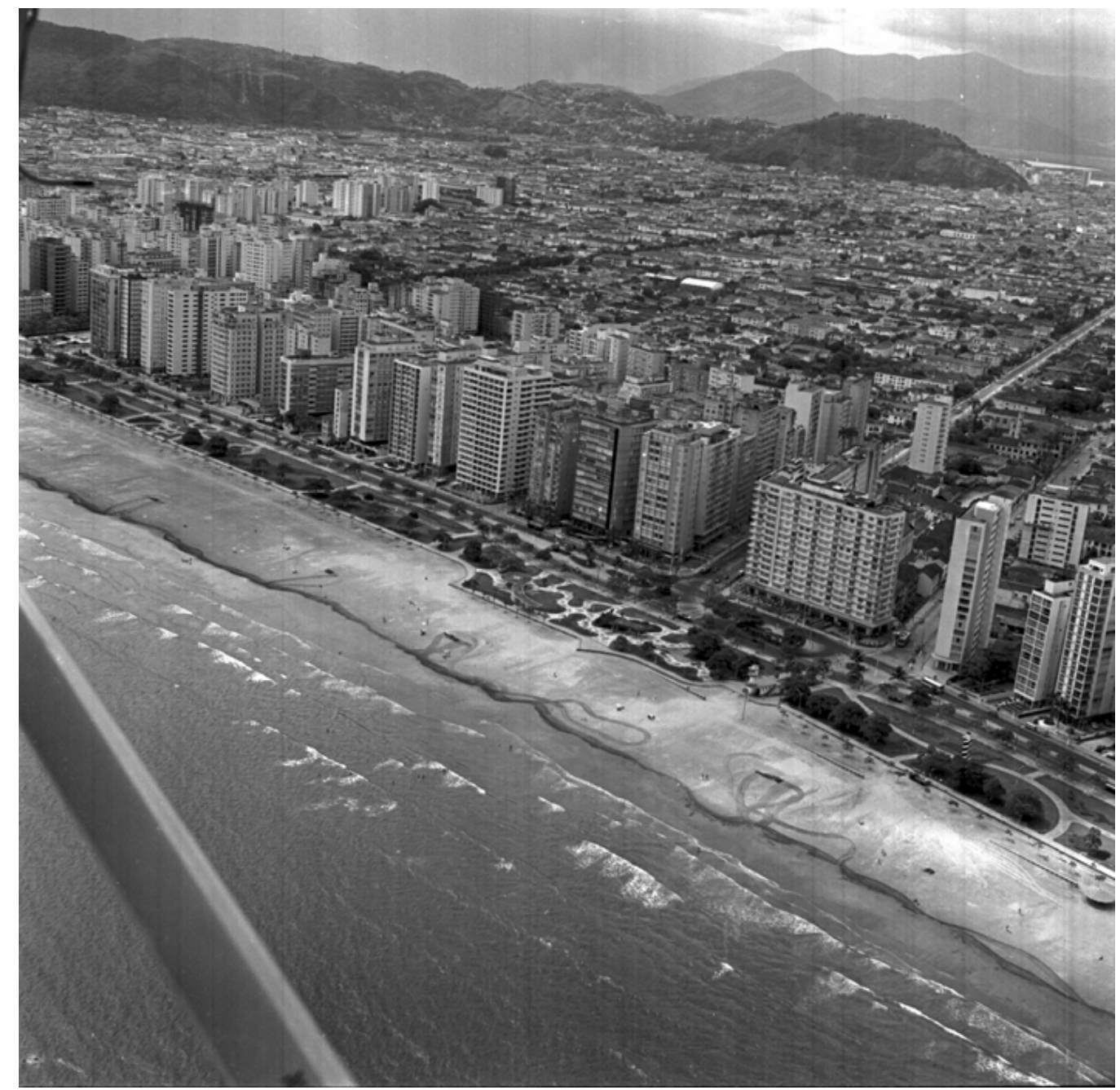

Vista panorâmica da orla praiana no trecho do bairro do Boqueirão, em frente à Av. Conselheiro Nébias, em Santos, na década de 1970.

A imagem nos mostra que os arranha-céus já tomaram conta de toda área próxima da praia, de frente ao mar. De um lado, vemos os jardins da orla, a areia e o mar. Do outro, a seqüência de edifícios. Na esquerda, mais ao canto, percebemos que os arranha-céus começam a avançar para dentro, em direção ao Centro.

José Herrera confessa que nunca imaginou que os grandes prédios tomariam conta da Cidade:

Quando comecei a fotografar, Santos tinha pouquíssimos prédios... Os prédios começaram a surgir próximos à praia, em meio aos casarões, entre as décadas de 1940 e 1950. Aparecia um aqui, outro ali e, quando as pessoas se deram conta, a orla já era toda 
cheia deles... Não desgosto dos prédios, mas sinto saudades daqueles casarões imponentes. Toda essa transformação aconteceu muito rápido, acho que ninguém esperava. ${ }^{174}$

A obra Memórias da Hotelaria Santista explica o aparecimento dos arranhacéus que, a partir década de 1950, se multiplicaram como um claro indício daquilo que se convencionou chamar de progresso.

A abertura da Rodovia Anchieta passou a trazer para a região da Baixada Santista um número cada vez maior de pessoas e, nas décadas de 1950 e 1960, com a instalação das grandes indústrias na Baixada Santista, a população aumentou consideravelmente em Santos e cidades vizinhas. Novos bairros foram nascendo para atender estes moradores e os antigos tornaram-se mais valorizados. Mas o fato que contribuiu decisivamente para determinar esta fase de ouro foi a especulação imobiliária e o aparecimento dos apartamentos na orla da praia. Os terrenos, extremamente valorizados, foram vendidos para a construção de edifícios de vários andares. Nem os palecetes escaparam da demolição. Era uma nova fase para Santos. ${ }^{175}$

Entre a grande massa de prédios de apartamentos que hoje formam uma enorme muralha na orla santista, destacam-se alguns mais conhecidos: o Olímpia, no José Menino, famoso por ter sido o precursor dos altos edifícios de apartamentos; o Enseada, na Ponta da Praia, e o Parque Verde Mar, no Gonzaga, ambos projetados com características da arquitetura modernista por João Artacho Jurado; e o Indaiá, no Boqueirão, que se apresenta em três blocos. ${ }^{176}$

\footnotetext{
174 Depoimento do fotógrafo. 05/04/2007.

175 GIRAUD Laire José et alli, Memórias da Hotelaria Santista, 1997, passim.

${ }^{176}$ ANDRADE, Wilma Therezinha F., Presença da Engenharia e Arquitetura - Baixada Santista, 2001, p. 84.
} 


\subsection{5 - EMISSÁRIO SUBMARINO}

O Emissário Submarino de Santos foi inaugurado em 21 de julho de 1978 com a presença do então presidente da República, general Ernesto Geisel. Sua construção passou a ser necessária para melhorar as condições sanitárias e a balneabilidade das praias. Na época, o bairro do Estuário e a Zona Noroeste ainda não contavam com o sistema de coleta de esgoto, o que já causava sérios problemas.

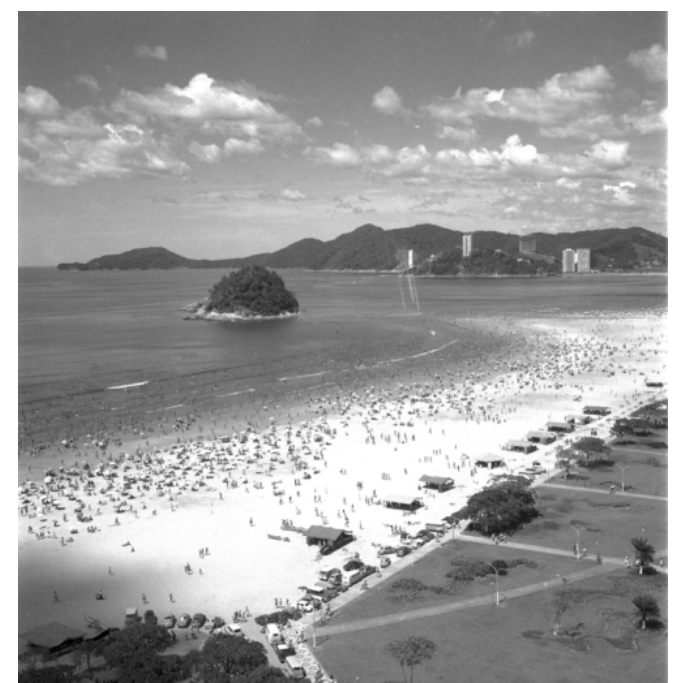

Orla da praia do José Menino sem o Emissário Submarino. Santos. Início da década de 1978. Gelatina/prata, $120 \mathrm{~mm}, 6 \times 6 \mathrm{~cm}$. Acervo FAMS.

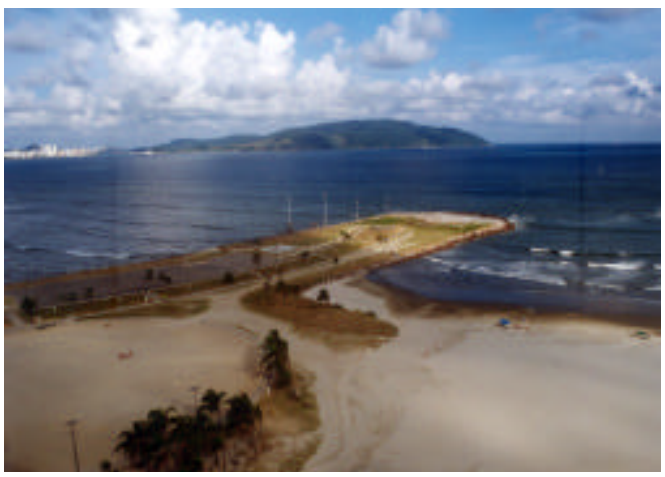

Emissário Submarino visto de cima. Santos. 2007. Gelatina/prata, $35 \mathrm{~mm}, 10 \times 15 \mathrm{~cm}$ Acervo particular José Dias Herrera.

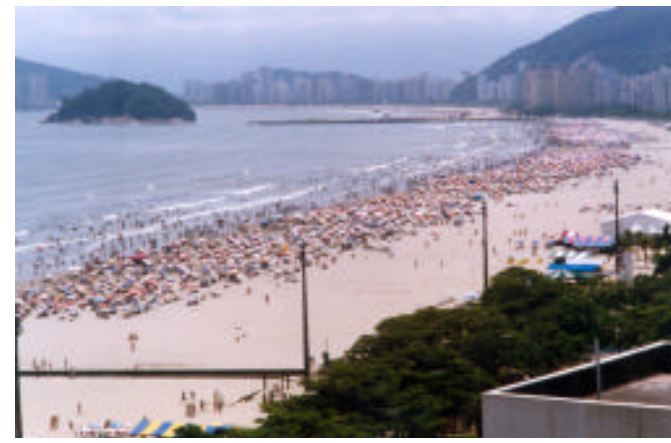

Orla da praia do José Menino, entre o Canal 1 e o Emissário Submarino. Destaque para a llha de Urubuqueçaba. Santos. 2005. Gelatina/prata, 35mm, $10 \times 15 \mathrm{~cm}$ Acervo particular José Dias Herrera. 


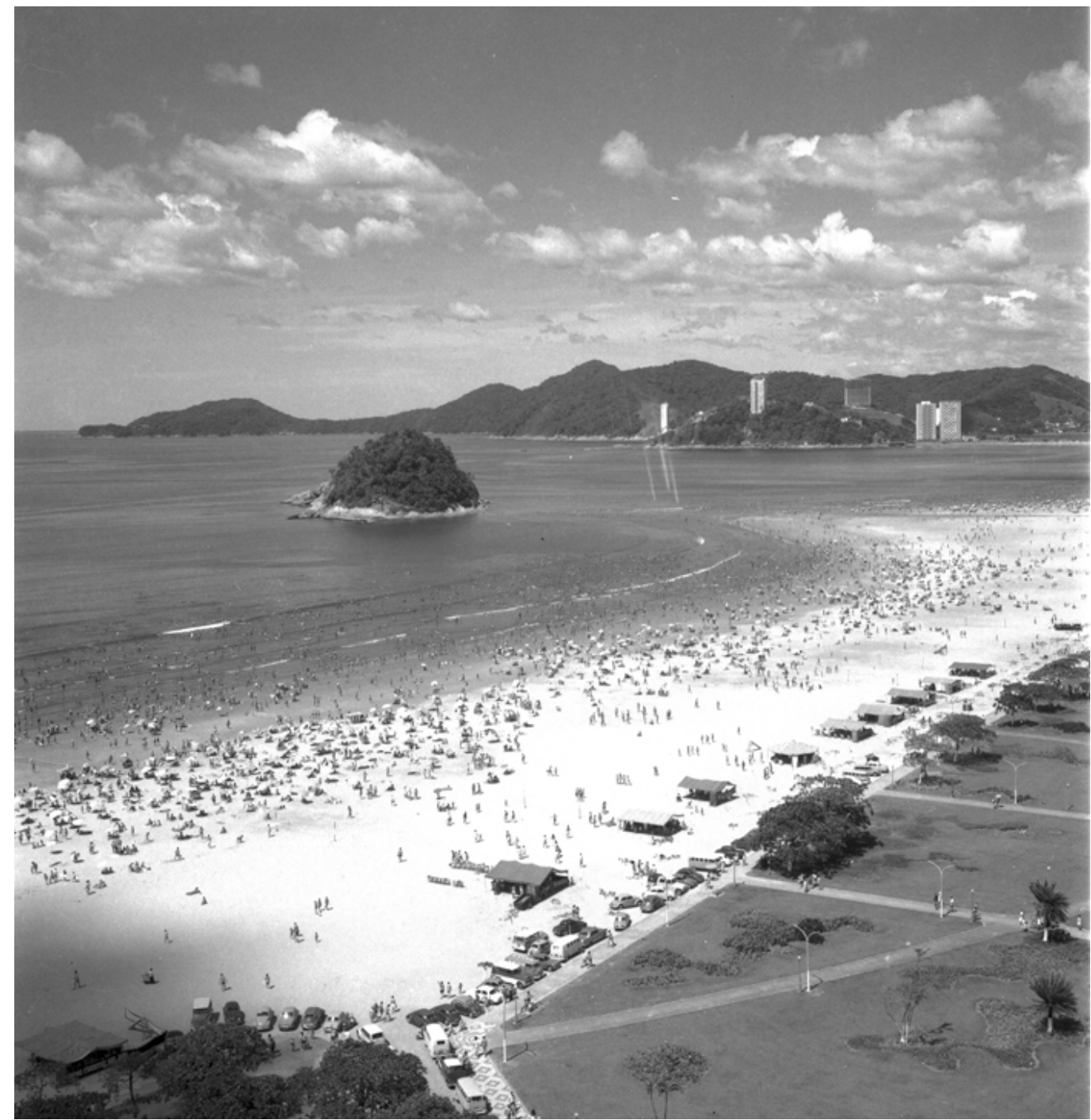

Orla da praia do José Menino no início da década de 1970, ainda sem o Emissário Submarino. Destaque para a Ilha de Urubuqieçaba.

A imagem mostra a quantidade de pessoas próximas ao mar e as barracas de associações montadas na faixa de areia, perto do calçadão, características de Santos. Nota-se também que os carros estão estacionados dentro da praia, na areia, encostados no calçadão - o que atualmente não é permitido. Nos jardins, podemos observar poucas árvores, como os chapéus-de-sol e pequenos coqueiros. Atualmente, os chapéus-de-sol acompanham todo o calçadão. Na faixa de areia também não encontramos os ambulantes que circulam vendendo biscoitos, sorvetes, milho ou amendoim e, tampouco, os carrinhos fixos de bebidas e pastel, tão comuns 
nos dias de hoje. No mar, ao centro, avistamos a Ilha Urubuqueçaba e, ao fundo, a Ilha Porchat, já em São Vicente, com alguns prédios.

Embora não tenha acompanhado a inauguração do Emissário Submarino, José Herrera lembra do acontecimento como algo marcante na vida do santista.

Não me recordo por que eu não fui fotografar. Quem estava lá era o meu irmão Rafael, fotografando para o jornal $A$ Tribuna. Nessa época, a vida de repórter fotográfico estava mais fácil porque as redações contavam com mais profissionais. Mas, mesmo sem ser escalado, quando dava tempo, eu gostava de registrar 0 acontecimento para, depois, vender a foto... Foi o Geisel quem inaugurou o Emissário... Foi uma obra muito esperada pelo povo porque veio para melhorar o nosso sistema de esgoto; foi uma obra fundamental pra Cidade. ${ }^{177}$

As palavras do fotógrafo são confirmadas pelo jornal $A$ Tribuna, que ressalta a importância do Emissário Submarino da Sabesp, inaugurado a 21 de julho de 1978, para a melhoria das condições sanitárias e da balneabilidade das praias de toda a região. Segundo o veículo, cerca de 3 mil pessoas receberam o então presidente da República, o general Ernesto Geisel, que veio a Santos para a inauguração, com muita festa e aplausos. Durante a solenidade, Geisel também presidiu a assinatura de contratos no valor de $\operatorname{Cr} \$ 11,2$ bilhões para execução de novas obras de água e esgoto na Grande São Paulo, Litoral e Interior. ${ }^{178}$

Segundo o site oficial da Prefeitura de Santos, o Interceptor Oceânico que recolhe as águas dos canais de drenagem foi construído sob a faixa de areia numa profundidade que vai de dois a quatro metros e possui uma extensão de 4.900 metros. O sistema de tratamento de esgoto tem capacidade para atender a uma população de 2 milhões de habitantes e serve às cidades de Santos e São Vicente.

\footnotetext{
177 Depoimento do fotógrafo. 05/07/2006.

178 Manifestação a Geisel na Baixada/Geisel inaugura Emissário e afirma que receberá Paulo Maluf. $A$ Tribuna. 22 de julho de 1978, p.01
} 
Já a plataforma do Emissário, sobre a areia, tem 400 metros de comprimento por 10 de largura. ${ }^{179}$ Com o passar dos tempos, a plataforma do Emissário começou a abrigar eventos diversos e passou a ser freqüentado pela população, como recorda José Herrera:

No Emissário já montaram de tudo: circo, parque de diversões... Agora, tem a tal Festa Inverno que acontece nos meses de julho... Muita gente vai pescar por lá também. Virou um local de lazer. Eu acho um lugar interessante para tirar fotos; é um ponto estratégico... Agora, me parece que a Prefeitura tem uma proposta pra ele, pra construir um museu ou qualquer coisa assim. O problema é que os projetos que apresentam nunca dão certo; nada vai pra frente no Emissário.

Passado pouco mais de um ano do depoimento de José Herrera, e após uma longa história de cerca de 30 anos de impedimentos e burocracias, a área do Emissário Submarino finalmente foi repassada ao Município e teve um projeto aprovado. Pela portaria $n^{\circ}$ 264, publicada em 16 de agosto de 2007, no Diário Oficial da União, o Ministério do Planejamento autorizou a cessão, ao Município, do espaço para a implantação do projeto As Ondas Santos 21, de autoria do arquiteto Ruy Otake, que será um parque público projetado com áreas verdes e uma enorme escultura da artista plástica japonesa Tomie Ohtake. A obra deve ser entregue à população santista em 18 de junho de 2008, data em que se comemora o centenário da imigração japonesa no Brasil. ${ }^{181}$

\footnotetext{
179 www.santos.sp.gov.br/comunicacao/historia/emissario

180 Depoimento do fotógrafo. 05/07/2006.

181 Sinal verde para projeto no Emissário. Jornal da Orla. Santos. 18 e 19 de agosto de 2007, p.9.
} 


\subsection{6 - AVENIDA E JARDINS DA PRAIA}

Conhecido como um dos mais belos cartões postais de Santos, os jardins da orla estão no Guinness Book of Records, o livro dos recordes, desde 2001, como o jardim frontal de praia de maior extensão do mundo. São 5.335 metros distribuídos ao longo de sete quilômetros de praias, do José Menino à Ponta da Praia.

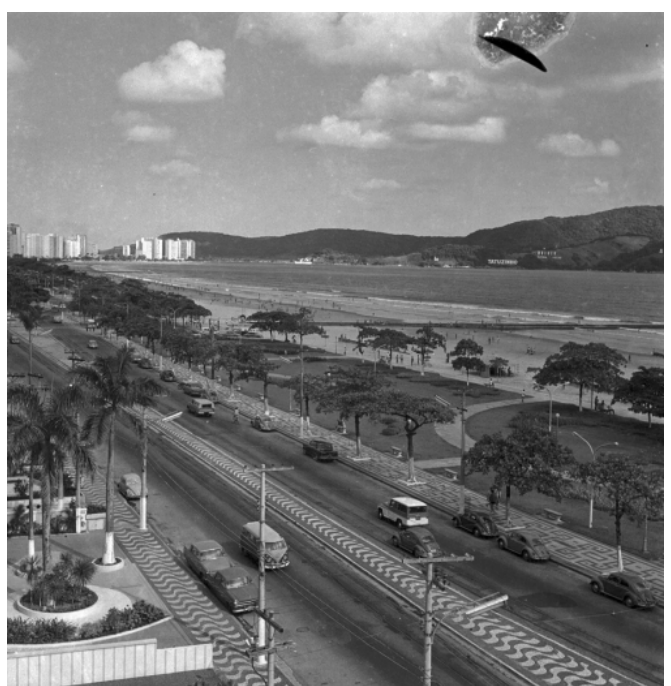

Urbanização da avenida da praia, no trecho próximo ao Canal 5. Santos. Meados da década de 1950. Gelatina/prata, $120 \mathrm{~mm}, 6 \times 6 \mathrm{~cm}$. Acervo FAMS.

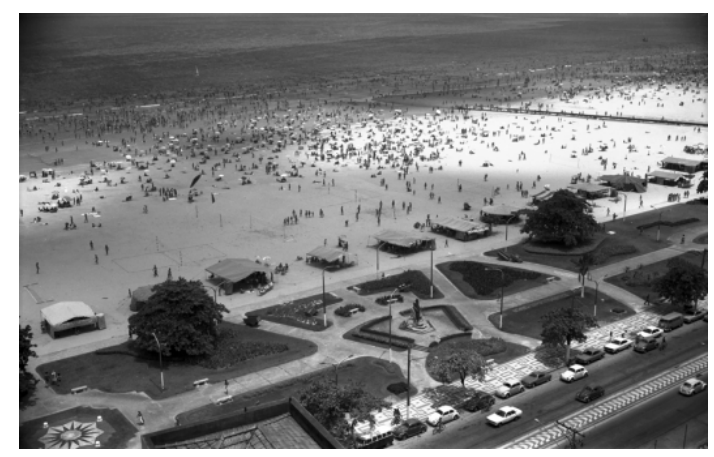

Trecho dos jardins da praia do Gonzaga. Destaque para o Monumento a Martins Fontes e, à esquerda, no chão, um relógio solar. Santos. Década de 1970. Gelatina/prata, $120 \mathrm{~mm}, 6 \times 6 \mathrm{~cm}$. Acervo José Dias Herrera.

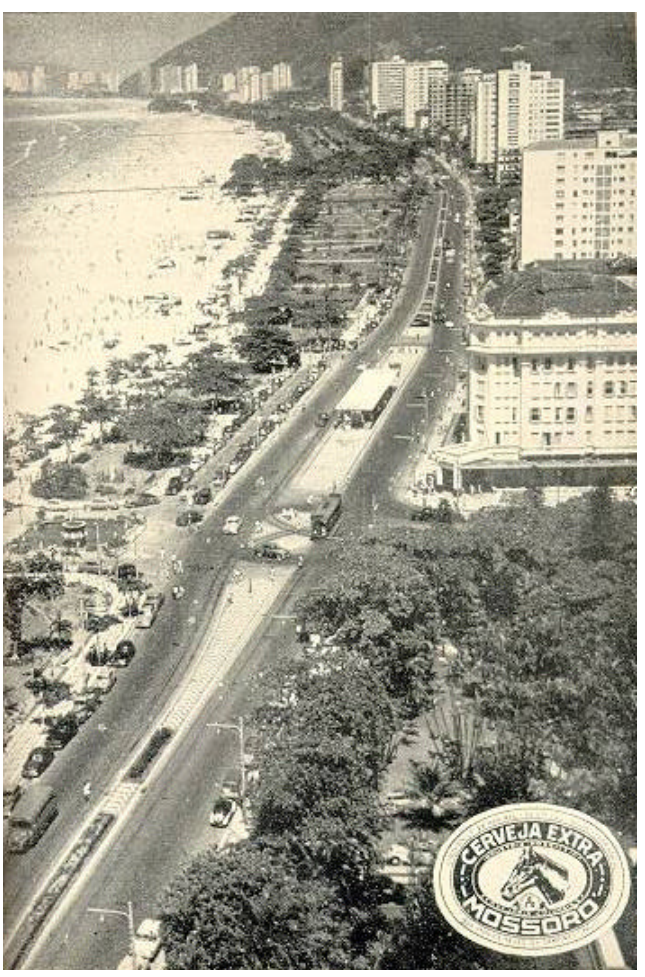

Avenida da praia do Gonzaga. Santos. 1955. Reprodução Guia Santista de 1956. 


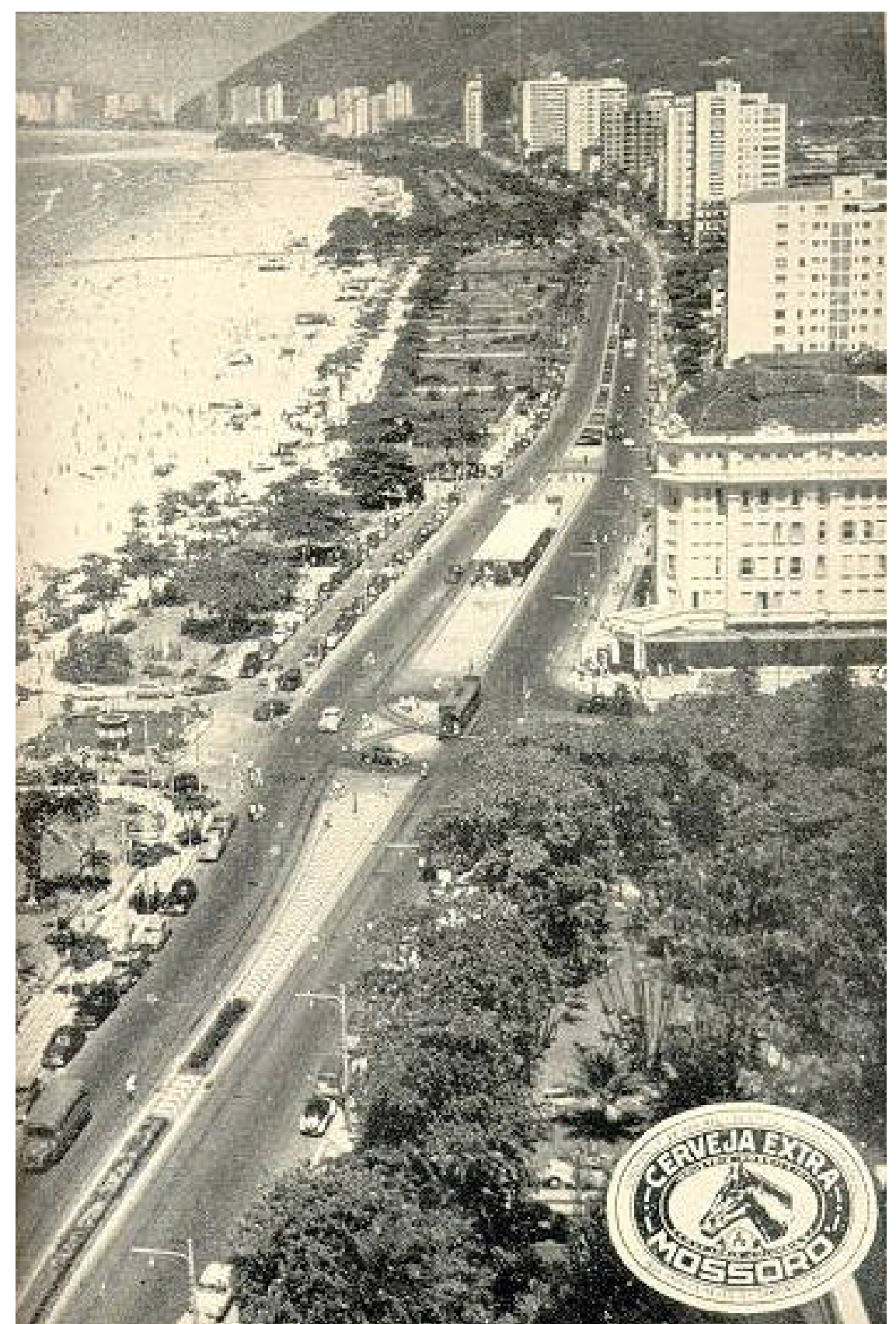

Orla e avenida da praia de Santos, no Gonzaga, no ano de 1955.

A imagem mostra, além da praia e dos jardins da orla, a Avenida Vicente de Carvalho com duas pistas pavimentadas para a passagem de carros, o canteiro central com um abrigo de bondes e as linhas do bonde acompanhando o canteiro. $\mathrm{Na}$ imagem, um bonde passa em frente à Avenida Ana Costa. Do lado da praia, na direção da avenida, podemos ver a Praça das Bandeiras com a Fonte Nove de Julho ao centro. $\mathrm{O}$ jardim no canto direito pertence ao Parque Balneário Hotel e, na outra esquina da Avenida Ana Costa, podemos ver o edifício do Atlântico Hotel. 
Percebemos ainda que, em frente ao Atlântico Hotel, entre os jardins e a avenida da praia, existia uma via mais estreita onde carros estão estacionados, que não existe mais atualmente. A imagem foi publicada no Guia Santista de 1956 e reproduzida com a logomarca de uma das empresas anunciantes nesse indicador, a antiga Cervejaria Mossoró, sediada em Campinas/SP e que teve fábrica em Santos.

José Herrera observa que a avenida da praia sofreu grandes alterações, mas foi sendo modificada aos poucos:

A avenida da praia nunca foi inteira igual em toda a sua extensão. Inventavam uma coisa num trecho, outra coisa no outro; mexiam aqui e ali. Me lembro que antigamente, bem no início da década de 1950, a avenida da praia tinha só uma pista de mão dupla e uma outra faixa exclusiva para os bondes. Depois, fizeram a segunda pista para os carros e os bondes circulavam pelo meio. Agora, nem mais trilho tem... Com os jardins foi a mesma coisa: construíam um pedaço, depois outro; depois foram colocando piso, construindo os monumentos... Deve ser por isso que ele não é todo igual. $^{182}$

Sobre o surgimento dos jardins da praia, consta que aconteceu em 1936, durante o governo do prefeito Aristides Bastos Machado, que construiu o trecho entre o Gonzaga e o Boqueirão, e mais um pedaço em direção ao José Menino. Depois, no governo de Antonio Gomide Ribeiro (1941-1945), as obras seguiram em direção à Ponta da Praia. Em 1953, com a posse do prefeito Antônio Feliciano, a área do José Menino foi construída e as já existentes melhoradas com obras de arte, calçadas e pisos em mosaico português. Quando o prefeito Silvio Fernandes Lopes assumiu, em 1965, finalizou o que faltava e implantou um sistema de iluminação, providenciando também o novo processamento para manter os jardins sempre floridos. ${ }^{183}$

\footnotetext{
${ }_{182}$ Depoimento do fotógrafo. 05/07/2006.

183 LICHTI, Fernando Martins, História de Santos - Poliantéia Santista, 1996, p.145.
} 


\subsection{7 - MONUMENTO A BRAZ CUBAS}

Localizada na Praça da República, o Monumento a Braz Cubas foi a primeira estátua erguida em Santos em homenagem ao seu fundador e está completando 100 anos em 2008.

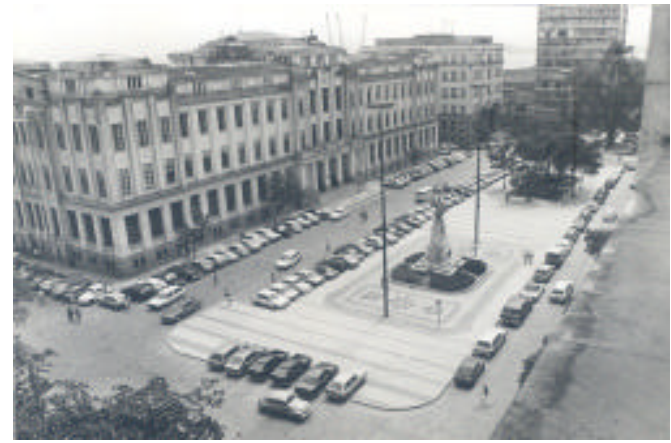

O Monumento a Braz Cubas, no centro da Praça da República. À esquerda, o prédio da Alfândega. Santos, Década de 1980 . Gelatina/prata, $6 \times 9 \mathrm{~cm}$. Acervo particular José Herrera.

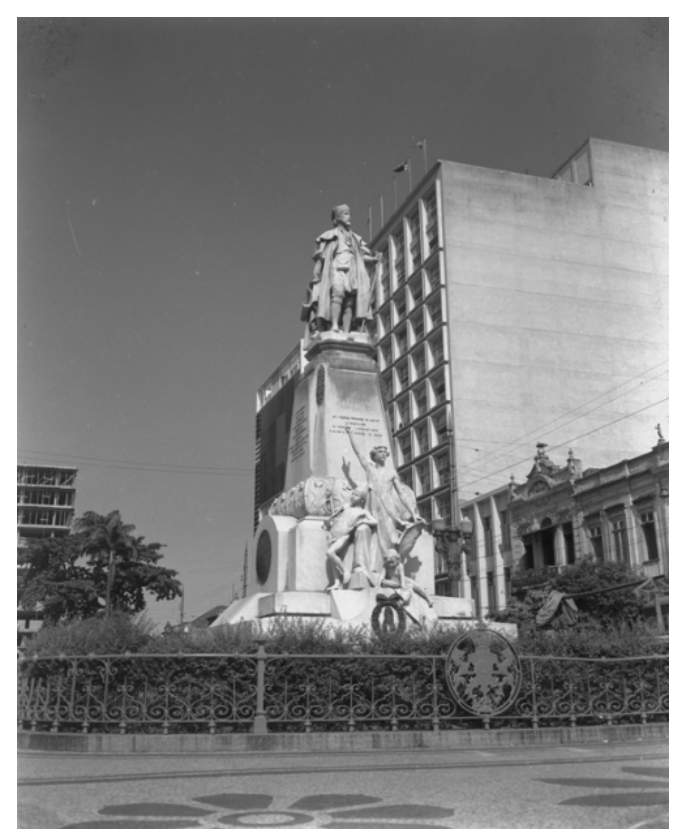

Monumento a Braz Cubas. Santos. Década de 1980. Gelatina/prata, $13 \times 15 \mathrm{~mm}$. Acervo particular José Herrera. 


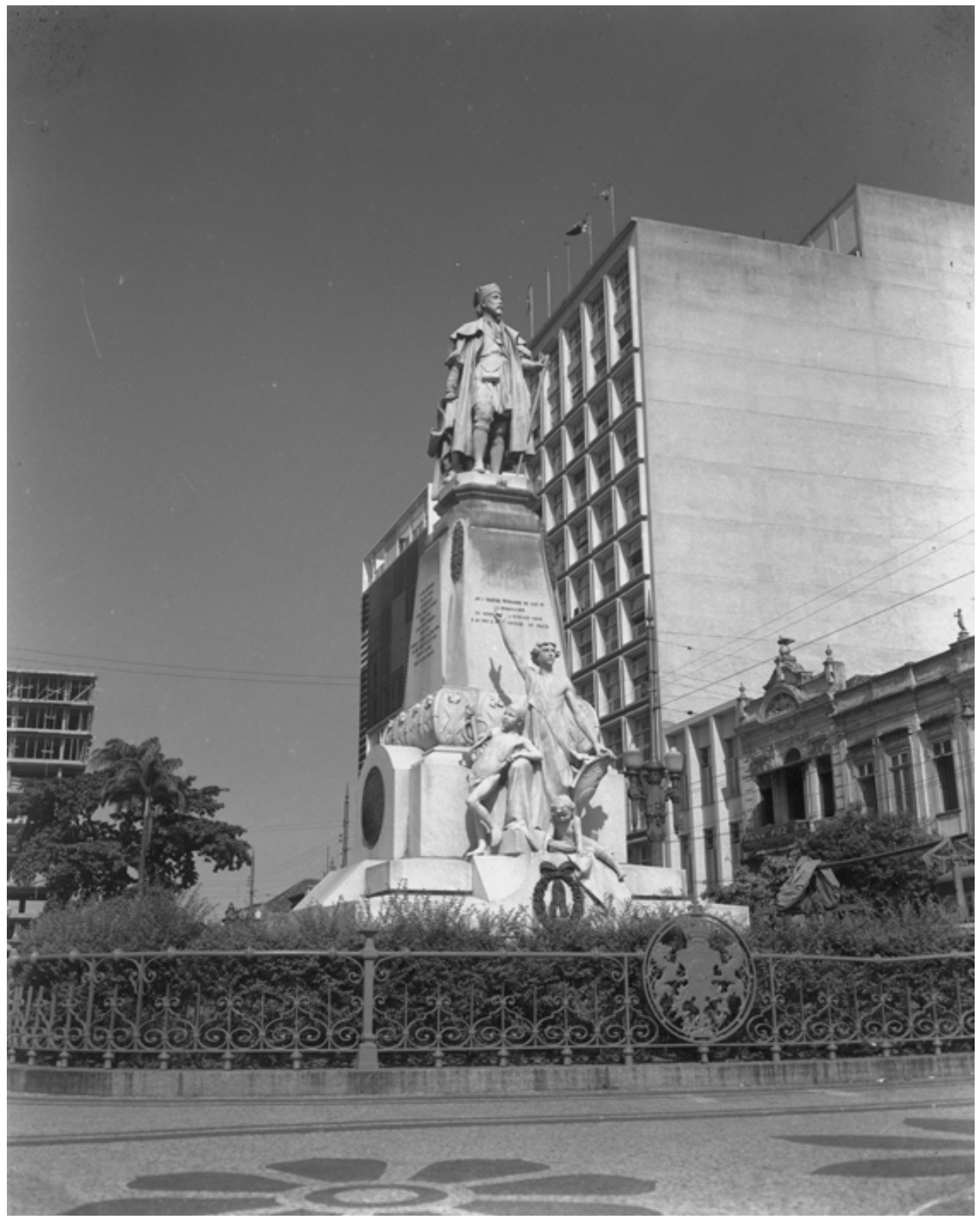

Monumento a Braz Cubas, localizado na Praça da República, no Centro Histórico de Santos. Década de 1980.

A foto mostra a frente do Monumento a Braz Cubas. Nota-se, na parte inferior, as alegorias à indústria, ao comércio e ao gênio criador do Homem. A obra apresenta, na parte superior, a figura de Braz Cubas segurando com a mão esquerda o bastão da realeza e olhando na direção do desenvolvimento da Cidade. Dois escudos de bronze, nas laterais da obra, ostentam a palavra Labor. Existe também uma coroa de bronze abaixo das alegorias, onde vê-se o brasão da Cidade 
como era na época: dos chanfros pendem festões de louro, que representam a honra e a vitória.

Inaugurado em 26 de janeiro de 1908, foi erguido por iniciativa da Câmara Municipal e esculpido em Gênova, pelo escultor italiano Lourenço Mazza, que a executou em mármore de Carrara. É considerado um obra-prima pelo seu equilíbrio estético. Dizem que na sua base estão os restos mortais de Braz Cubas, retirados da antiga Igreja Matriz, demolida pouco antes da colocação do monumento na Praça da República. ${ }^{184}$

O jovem português Braz Cubaz veio para o Brasil com a expedição de Martim Afonso e teve pioneira atuação na fundação da Vila de Santos, contribuindo também para a fundação da Irmandade da Santa Casa da Misericórdia de Santos, a primeira do Brasil. ${ }^{185}$

\footnotetext{
${ }^{184}$ LICHTI, Fernando Martins, Poliantéia Santista, 1996, p. 178.

185 ANDRADE, Wilma Therezinha F., Santos - um encontro com a História e a Geografia, 1992, p. 117.
} 


\subsection{8 - INAUGURAÇÃO DA VIA ANCHIETA}

No ano de 1933, o Caminho do Mar, ou Estrada Velha, já estava obsoleto e não atendia às necessidades viárias do desenvolvimento de São Paulo. Adhemar de Barros, então interventor do Estado, iniciou, em junho de 1939, a construção de uma nova estrada ligando o planalto a Santos, que se chamaria Anchieta. As obras sofreram várias paralisações, mas, em abril de 1947, o já então governador Adhemar de Barros inaugurou a pista ascendente da Via Anchieta. Em 09 de julho de 1953, a segunda pista e o trecho de Cubatão foram entregues.
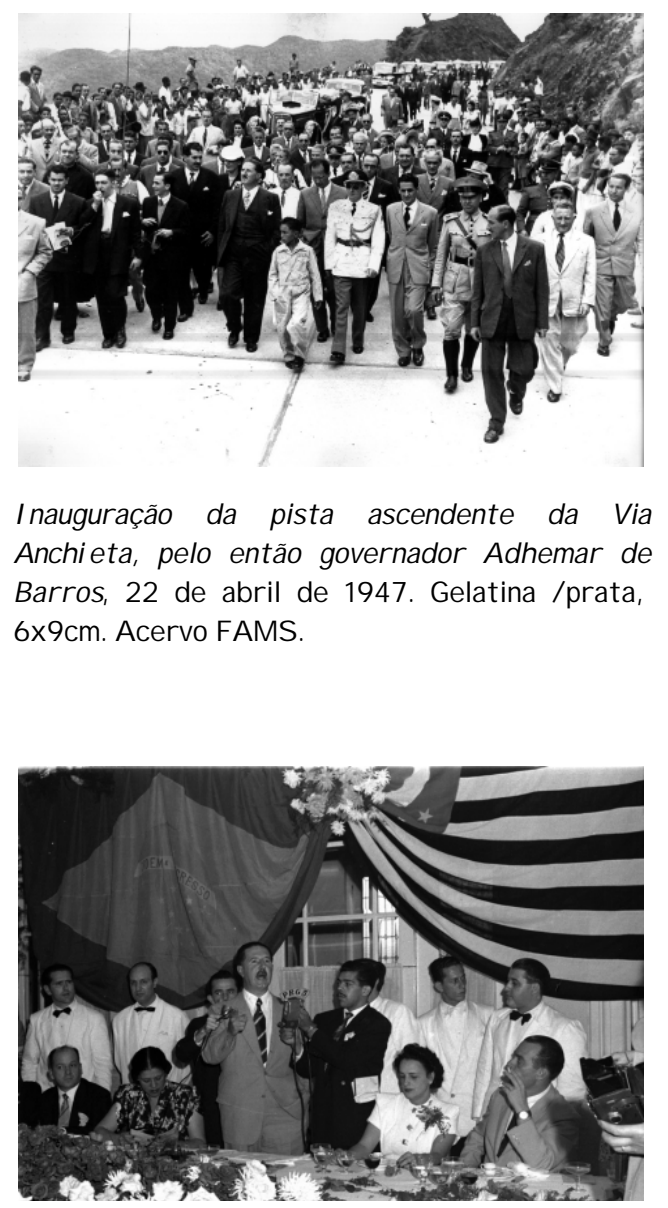

Discurso do governador Adhemar de Barros durante almoço no Parque Balneário Hotel. Santos. 22 de abril de 1947. Gelatina/prata, $6 \times 9 \mathrm{~cm}$. Acervo $\mathcal{F A M S}$. 


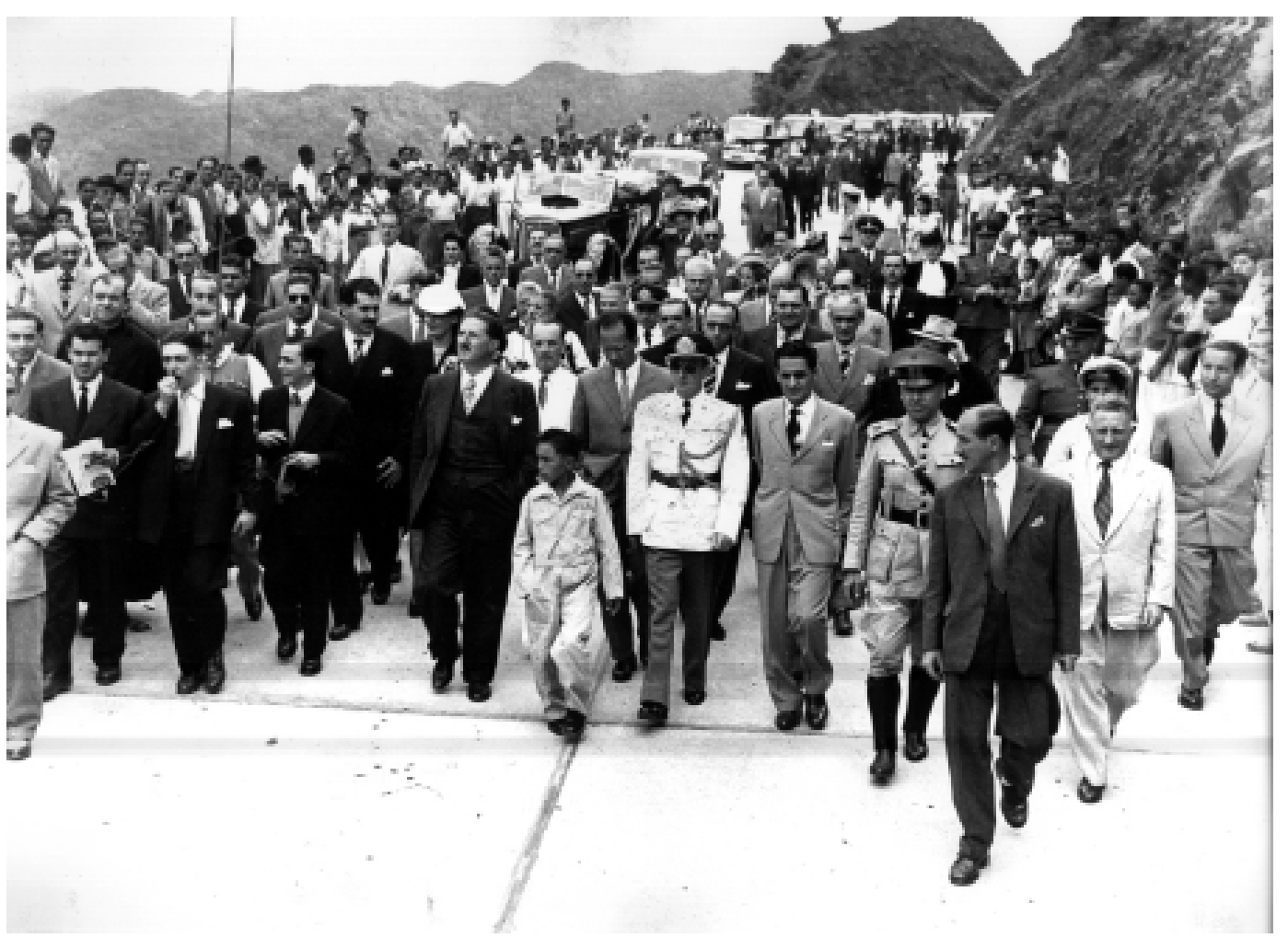

Inauguração da primeira pista da Via Anchieta, a ascendente, em 22 de abril de 1947, pelo então governador paulista Adhemar de Barros.

O governador aparece na foto, ao centro, de bigode. Ao seu lado, o garoto de 14 anos José Barreto, o trabalhador mais jovem da estrada, que cortou a fita simbólica, ato que inaugurou oficialmente a rodovia. José Herrera lembra como era a velha estrada:

A construção da Anchieta facilitou muito a vida das pessoas, foi uma idéia espetacular. A antiga estrada (Caminho do Mar) era terrível, de terra. Eu levava horas para ir a São Paulo. Quando chovia, os carros atolavam na lama e, às vezes, nem se podia seguir viagem, era uma terra vermelha e escorregadia. Em dias quentes, tínhamos que ir parando pelo caminho para esperar a poeira baixar para enxergar o que vinha pela frente... Como era difícil a estrada velha. ${ }^{186}$

A Via Anchieta, como seria chamada a estrada sucessora do já ultrapassado Caminho do Mar, demandou mais de 17 anos para ser concretizada: quatro anos

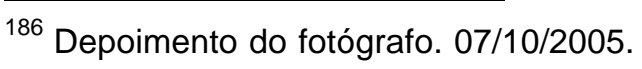


foram gastos só em estudos e projetos e os demais foram consumidos na construção. E, ainda assim, a nova rodovia foi aberta operando apenas a pista ascendente. A segunda pista da Anchieta e o trecho da Baixada Santista, entre as cidades de Cubatão e Santos, só seriam abertos ao tráfego seis anos depois, em julho de $1953 .^{187}$

O fotógrafo recorda também que a rodovia impressionava pela sua engenharia. "Foi a primeira estrada do Brasil a ter túneis. As pessoas ficavam maravilhadas com aquilo tudo. Eu mesmo fiquei. Era tudo bem moderno e diferente mesmo. Foi um sucesso fantástico" ${ }^{188}$. O pesquisador Paulo Monteiro confirma a sua descrição:

Com 58 viadutos, 18 pontes, cinco túneis e $55,9 \mathrm{~km}$ de extensão, a Via Anchieta é um marco na história da engenharia brasileira. Primeira rodovia do país a contar com túneis, a Anchieta incorpora criativas soluções elaboradas por engenheiros e projetistas brasileiros. ${ }^{189}$

A construção da Rodovia Anchieta teve grande importância para o desenvolvimento do Estado de São Paulo e de todo o Brasil. Tão logo entrou em operação, passou a constituir-se num dos mais importantes corredores de exportação e de fluxo turístico do País, promovendo sensível aumento de veículos entre o planalto e o litoral. Em 1948, ano seguinte à sua inauguração, 830 mil veículos passaram pela estrada. Quatro anos depois, esse movimento saltava para 1,9 milhão de veículos. ${ }^{190} \mathrm{O}$ jornal $A$ Tribuna também ressaltou a importância da nova rodovia:

\footnotetext{
${ }^{187}$ MONTEIRO, Paulo Gonzalez, A Conquista da Serra do Mar, 2002, p.80.

188 Depoimento do fotógrafo. 07/10/2005.

189 MONTEIRO, Paulo Gonzalez. A Conquista da Serra do Mar, p.80.

190 lbid, p.85
} 
Mas não é apenas sob o ponto de vista turístico social que a Via Anchieta virá a exercer sua grande influência. Será, principalmente, no transporte de mercadorias, aumentando notavelmente a capacidade do tráfego rodoviário entre o nosso porto e o altiplano e concorrendo para alimentar mais depressa essa insaciável fome de mercadorias de importação. Encurtando as viagens, exigindo menos dispêndio de combustível, evitando maiores desgastes de veículos, proporcionando outra segurança daí resultarão incalculáveis vantagens econômicas. ${ }^{191}$

\footnotetext{
${ }^{191}$ Via Anchieta, estrada-marco da grandeza de São Paulo, a glorificar a memória do jesuíta lendário.
} A Tribuna. Santos, 23 de abril de 1947, p.3 


\subsection{9 - DESLIZAMENTOS DE MORROS EM 1956}

Nos morros santistas, ocorreram vários deslizamentos célebres, como o que aconteceu no Monte Serrat no século XVII e soterrou um grupo de corsários holandeses que tinham a intenção de saquear a Vila. ${ }^{192}$ Outros deslizamentos graves aconteceram em 1928, 1956 e na década de 1980, deixando mortos e feridos.

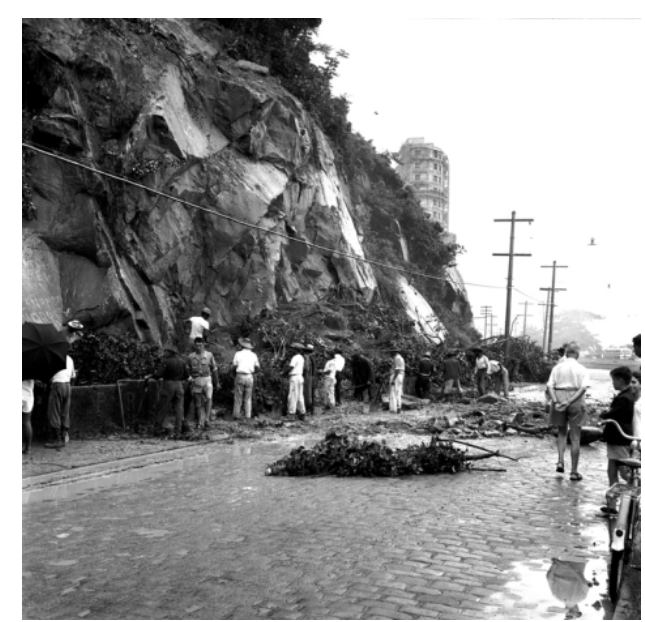

Deslizamento do Morro do Marapé. Santos. Março de 1956. Gelatina/prata, 6x9cm. Acervo FAMS.

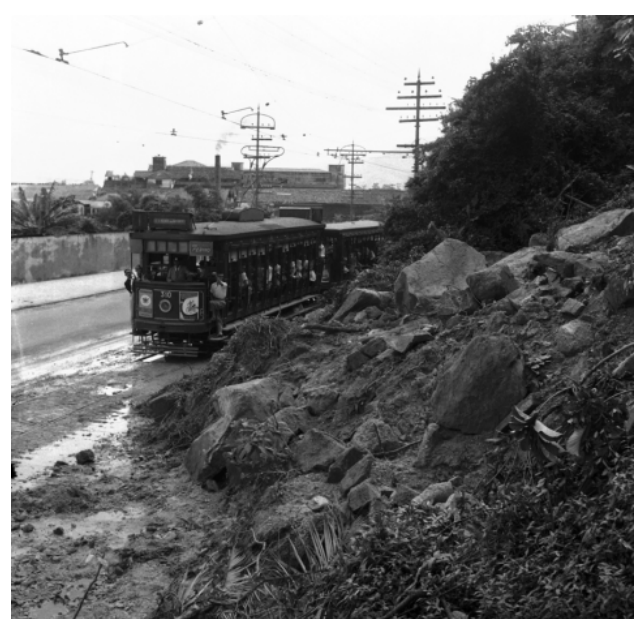

Deslizamento do Morro do Marapé, que obstruiu a linha dos bondes. Santos. Março de 1956. Gelatina/prata, $6 \times 9 \mathrm{~cm}$. Acervo FAMS.

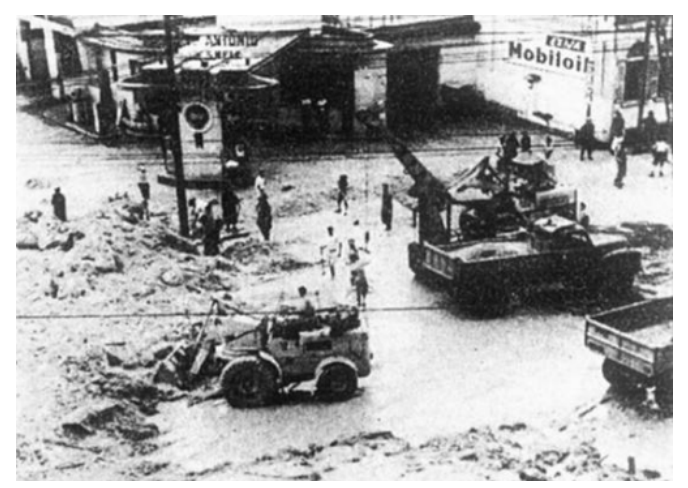

Retirada de lama e pedras das ruas do bairro do Marapé. Santos. Março de 1956. Reprodução imagem em papel. Acervo José Dias Herrera.

\footnotetext{
${ }_{192}$ O caso que foi atribuído a um milagre de Nossa Senhora do Monte Serrat, a santa padroeira da Cidade.
} 


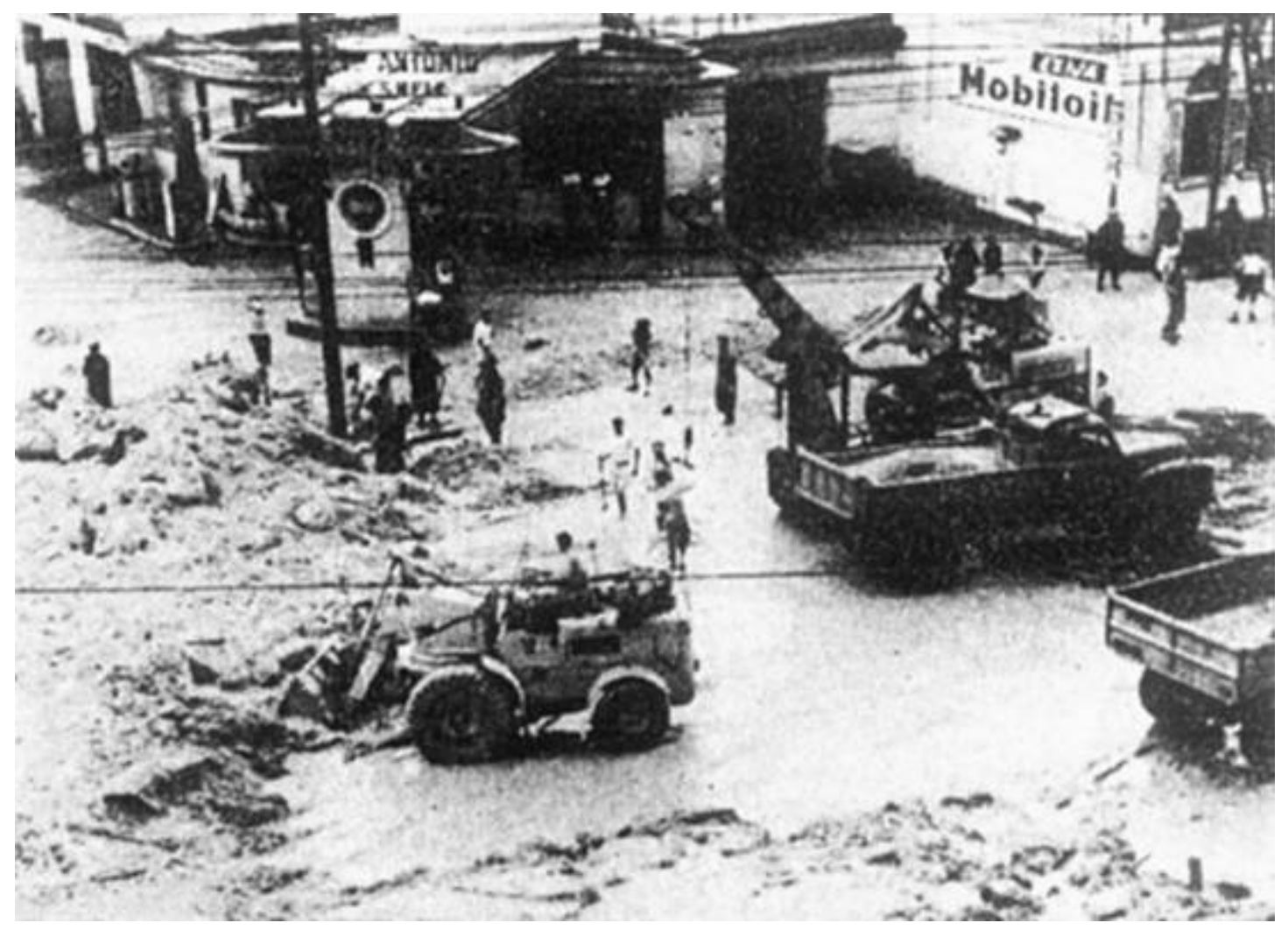

Retirada de lama, pedras e entulho das ruas atingidas pelo deslizamento no Morro do Marapé, no dia $1^{\circ}$ de março de 1956.

Uma forte chuva provocou uma avalanche que soterrou cerca de 20 chalés no sopé do morro, no lado final da Rua João Caetano ${ }^{193}$. Os veículos que aparecem na imagem são tratores, empilhadeiras e caçambas. Foram cedidos pelo Departamento de Estradas de Rodagem - DER e vieram de Cubatão, Cotia, Itapecerica da Serra e São Bernardo do Campo, junto com mais de 140 homens para ajudar no rescaldo. José Herrera comenta:

Naquele ano (1956) aconteceram vários desastres nos morros de Santos. Chovia muito, formava muita enchente e tudo desmoronava, a terra descia com tudo. A chuva castigava demais

\footnotetext{
${ }^{193} \mathrm{Na}$ Rua Godofredo Fraga, todo um quarteirão foi atingido. As chuvas começaram às $14 \mathrm{~h} 30$ e se intensificaram após as 16 horas, por cerca de 8 horas. Infelizmente, 22 pessoas morreram. A Tribuna, No Morro do Marapé, 22 mortes, 03 de março de 1956, p.3.
} 
mesmo. Quando deslizou o Morro do Marapé até o Jânio Quadros veio a Santos averiguar os estragos. $O$ desastre chocou todo 0 Brasil [...] Essa catástrofe aconteceu à noite. Cheguei lá no dia seguinte para registrar o acontecimento e quase morri. Para tirar uma panorâmica, eu subi em cima de uma pedra e quase caí num buraco muito estreito, encoberto de terra. Me segurei não sei como. Não afundei por sorte. Se eu tivesse caído ninguém me acharia no meio daquele tumulto e daquela lama toda. ${ }^{194}$

${ }^{194}$ Depoimento do fotógrafo. 31/05/2006. 


\subsection{Patrimônios da Arquitetura Santista}

A arquitetura e a engenharia acompanham o evoluir das ciências exatas e da tecnologia para responder às múltiplas necessidades e exigências da sociedade, e trabalham conforme as épocas. Materiais, técnica, dimensões e estilo espelham variáveis econômicas, de espaço e tendências do momento, adaptando, inovando e criando soluções. Ressalta-se a importância do patrimônio construído como sinal de atividade, de posse, de identidade nacional e regional.

Em Santos, várias épocas e estilos arquitetônicos estão eternizados em inúmeras construções espalhadas por toda a Cidade. As edificações que restaram atestam a vida dos dias antigos, memórias concretas de etapas ultrapassadas. Documentando o passado, elas fazem com que ele permaneça entre nós. Ou, revitalizadas, possam reviver em outra função. ${ }^{195}$

José Herrera registrou muitos patrimônios que são símbolos da Cidade de Santos: monumentos exuberantes preservados até hoje, como o Palácio José Bonifácio (Paço Municipal) e o prédio da Bolsa Oficial de Café; prédios sagrados como a Basílica de Santo Antonio do Embaré; edifícios abandonados que se transformaram em ruínas, como o Teatro Guarani; e até construções infelizmente já demolidas, como o antigo hotel Parque Balneário. Todas estas imagens preservam um pouco da história e da identidade santistas.

\footnotetext{
${ }^{195}$ ANDRADE, Wilma Therezinha F., Presença da Engenharia e Arquitetura - Baixada Santista, 2001. Apresentação.
} 


\subsection{1 - O ANTIGO HOTEL PARQUE BALNEÁRIO}

Inaugurado em 1924, o antigo Parque Balneário foi um empreendimento de vanguarda e um dos mais luxuosos hotéis do Brasil entre as décadas de 1930 e 1960. Tinha cassino, boate, grill de verão, centro de convenções, bar executivo, restaurante de alto luxo e recebeu personalidades de todo o mundo. Era o grande diferencial turístico da época. ${ }^{196}$
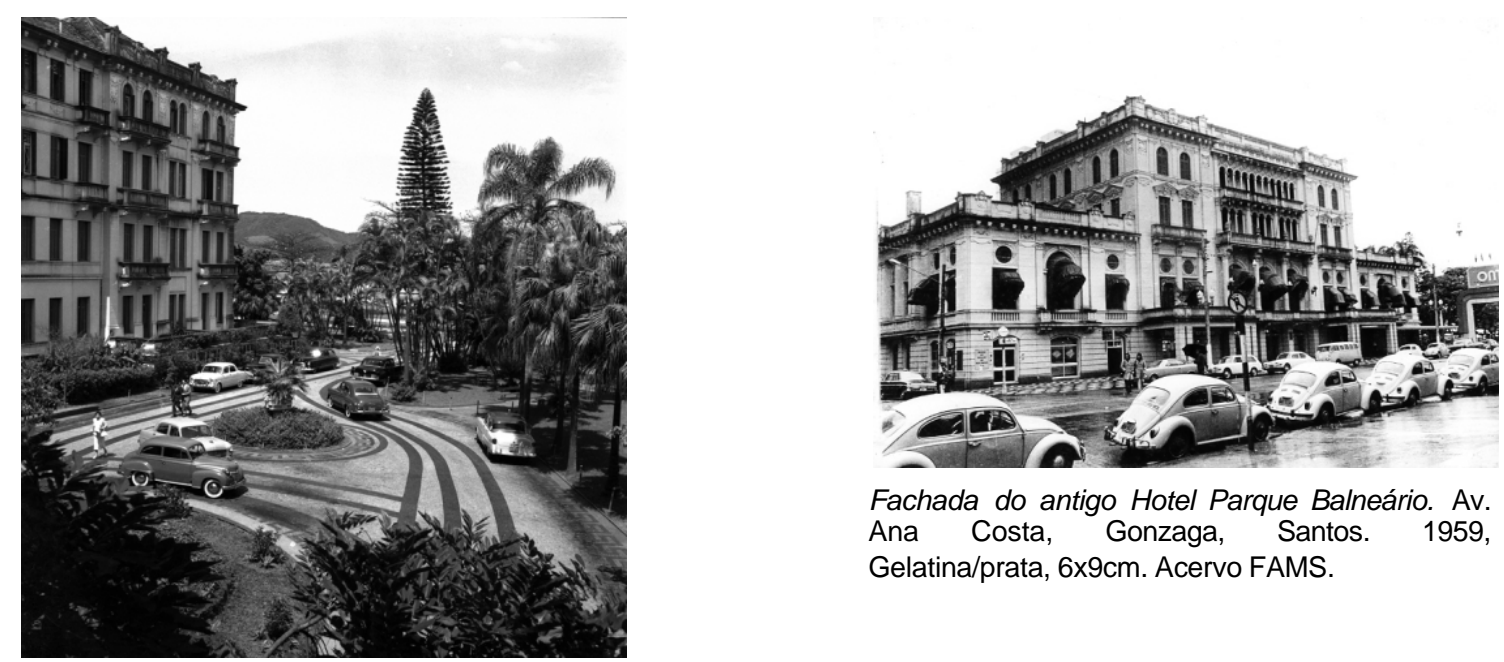

Fachada do antigo Hotel Parque Balneário. Av. Ana Costa, Gonzaga, Santos. 1959, Gelatina/prata, $6 \times 9 \mathrm{~cm}$. Acervo FAMS.

Jardins do antigo Hotel Parque Balneário. Gonzaga, Santos. 1952, Gelatina/prata, 6x9cm. Acervo FAMS.

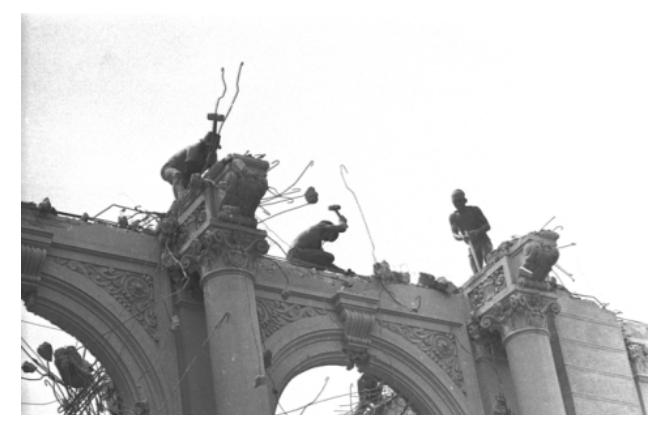

Demolição do antigo Hotel Parque Balneário. Gonzaga, Santos. 1976, Gelatina/prata, 10x15cm. Acervo FAMS.

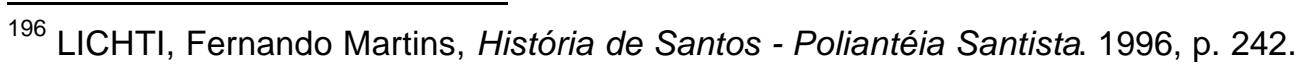




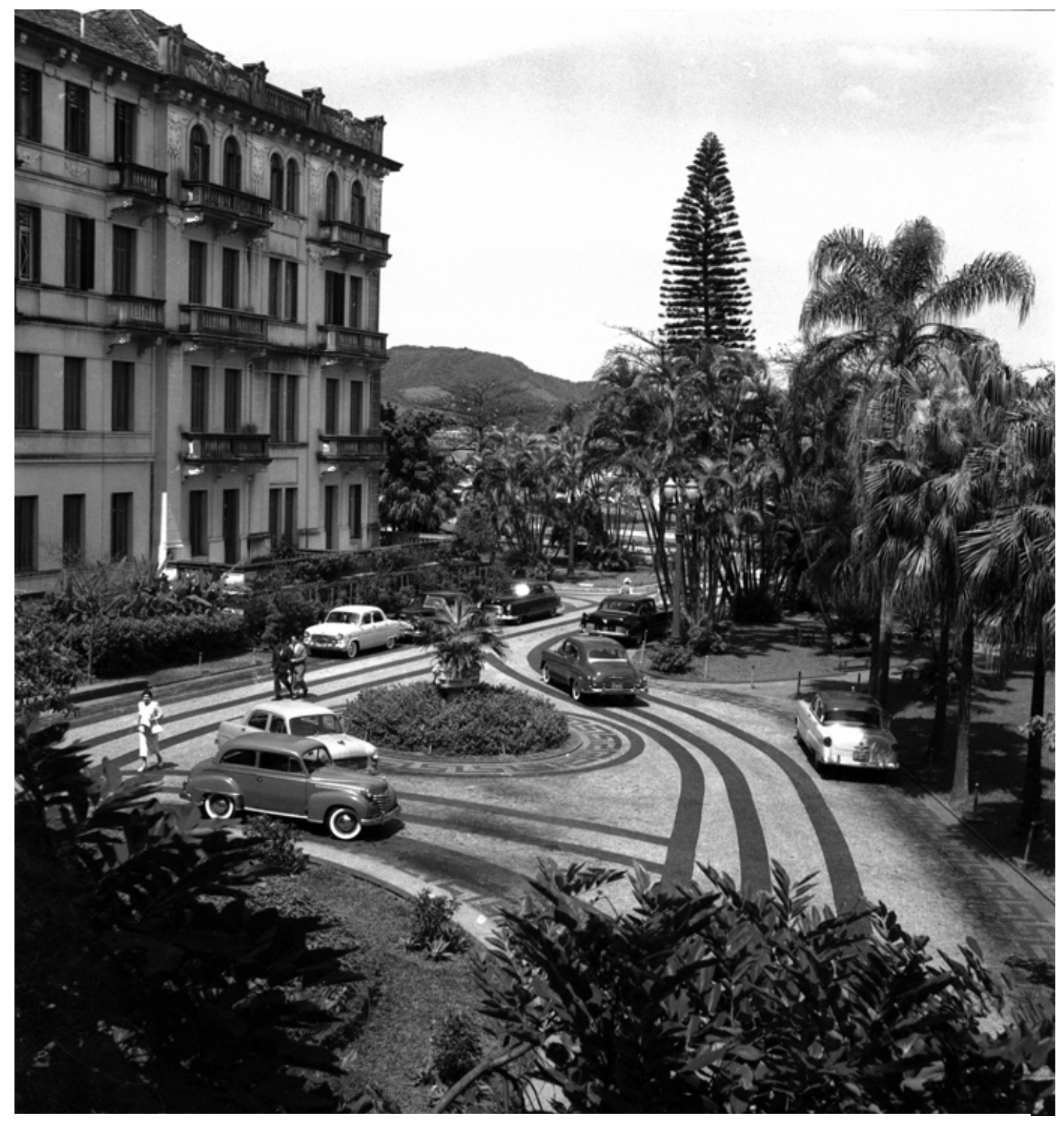

Jardins do antigo Hotel Parque Balneário, em 1959.

Na imagem, além de perceber que os jardins do antigo Hotel Parque Balneário tinham piso em mosaico português, vemos também muitas palmeiras e plantas com características tropicais e um único pinheiro. Notamos a circulação de carros, como o Dodge Plymouth escuro, à esquerda, e o Cadilac Rabo de Peixe branco, estacionado à direita. $\mathrm{Na}$ área, aconteciam festas e havia um jardim de inverno todo de vidro com iluminação sob o piso. A formação ao fundo é o município de Guarujá. 
Para José Herrera, a demolição do Parque Balneário foi o maior crime que se cometeu contra a Cidade.

Foi um absurdo demolirem um edifício tão bonito e importante... Aquilo era uma maravilha. É revoltante [...] O Parque Balneário chegou a ser considerado o melhor hotel da América do Sul. Lá, aconteciam vários shows internacionais, bailes e grandes eventos, com a apresentação de músicos famosos... Muita gente importante, principalmente políticos, se hospedou ali... Era um glamour só, nenhum outro lugar oferecia tanta coisa e recebia tanta gente chique. ${ }^{197}$

Em 2004, o Diário Oficial de Santos resumiu a história do antigo hotel:

Adquirido em 1912 pelos irmãos Fraccaroli, o primitivo Parque Balneário era, até então, uma construção pequena. Depois das reformas iniciadas em 1922, passou a ocupar um quarteirão inteiro, limitado pelas avenidas da praia e Ana Costa e ruas Fernão Dias e Carlos Afonseca. O material empregado em sua construção foi quase todo importado. O mármore veio da Itália e de Portugal. As peças sanitárias e as pastilhas do chão eram inglesas. Os cristais dos lustres e das taças tinham origem tcheca. A mobília e os talheres, todos de prata, provinham da França. Em sua fase áurea, o Parque Balneário contava com cinco salões: o Dourado, de banquetes; o Kursall, de jogos; o restaurante; o salão de leitura e o carteado, além de uma boate e um jardim que tinha pista de dança e fonte luminosa. Chegou a manter salão de beleza, padaria e frigorífico. Com a proibição do jogo e devido às crises que assolaram o país, entrou em decadência na década de 60 e, em 1966, foi vendido ao Santos Futebol Clube. Problemas com o pagamento do imóvel fizeram com que os Fraccaroli retomassem o hotel, que foi vendido novamente no ano de 1972, desta vez para um grupo financeiro que, em 1976, iniciou a sua demolição. ${ }^{198}$

Atualmente, o local que abrigava o antigo hotel Parque Balneário é ocupado por um shopping center, por outro hotel de mesmo nome e por edifícios residenciais.

\footnotetext{
${ }_{197}$ Depoimento do fotógrafo. $10 / 11 / 2005$.

198 Hotel Parque Balneário. Diário Oficial de Santos. 28 de maio de 2004, p.2. (coluna Memória Santista).
} 


\subsection{2 - SANTA CASA DE SANTOS}

A primeira Santa Casa de Misericórdia de Santos, o mais antigo hospital brasileiro, foi inaugurada em novembro de 1543, próxima à atual Praça da República. A construção do segundo prédio foi concluída em 1665, no Campo da Misericórdia, atual Praça Visconde de Mauá. O terceiro, inaugurado pelo Dr. Cláudio Luiz da Costa em 1836, junto ao morro de São Jerônimo, atual Monte Serrat, foi parcialmente destruído por um deslizamento de terra em 1928. O conjunto atual, único remanescente, foi inaugurado pelo Presidente Getúlio Vargas, em 1945.

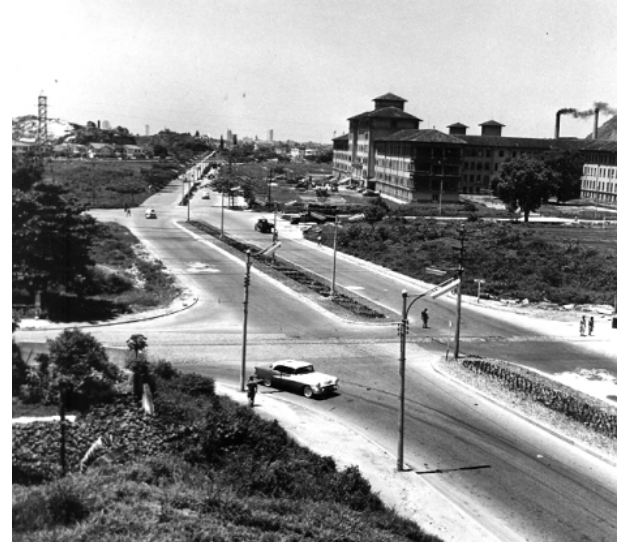

Quarto e atual prédio da Santa Casa. Santos, Final da década de 1950, Gelatina/prata, $9 \times 12 \mathrm{~cm}$. Acervo FAMS.

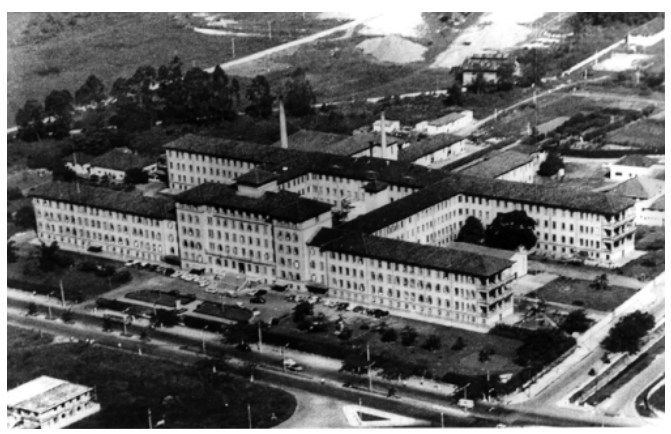

Panorâmica do quarto e atual prédio da Santa Casa. Santos. À direita, o canal da Avenida Francisco Manoel, Início da década de 1960, Gelatina/prata, $9 \times 12 \mathrm{~cm}$. Acervo FAMS.

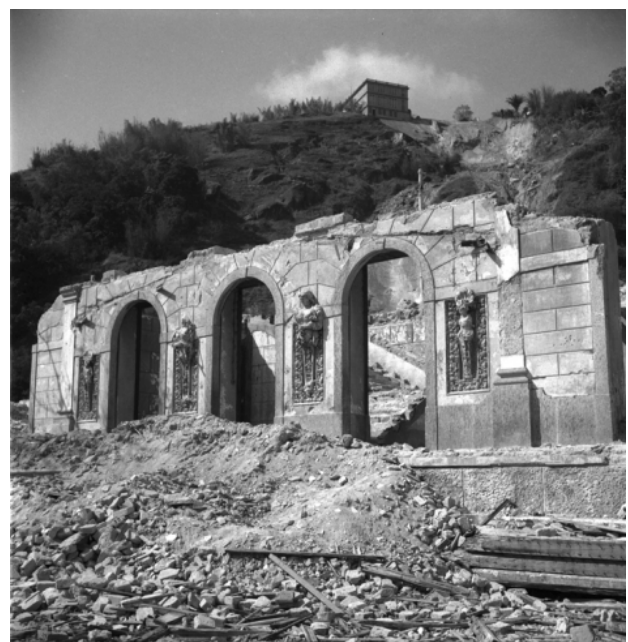

Restos da entrada do terceiro complexo da Santa Casa. Santos, 1976, Gelatina/prata, $6 \times 9 \mathrm{~cm}$. Acervo FAMS. 


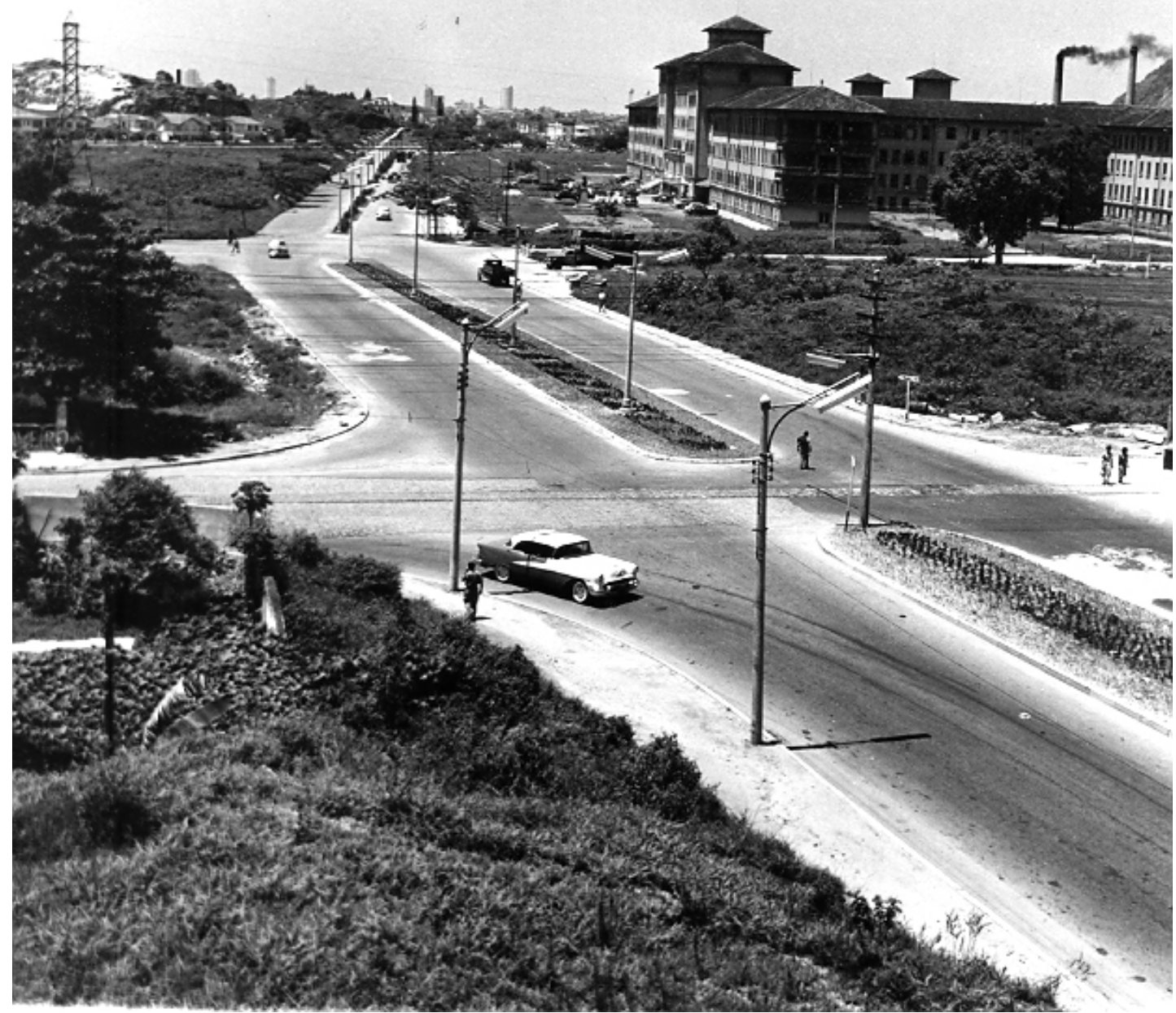

Quarto e atual prédio da Santa Casa de Misericórdia de Santos no final da década de 1950.

Como podemos observar na foto, não existia nada no entorno da Santa Casa naquela época. O terreno à direita, hoje abriga o Centro de Treinamento do Santos Futebol Clube e no terreno à frente atualmente existe uma lanchonete e um posto de gasolina. O veículo em primeiro plano, um Chevrolet, está saindo da Avenida Rangel Pestana e entrando na Rua Waldemar Leão, em direção ao Centro da Cidade.

Apesar de gostar do atual prédio da Santa Casa, José Herrera lamenta a demolição do antigo edifício, localizado no Monte Serrat. "O antigo era um prédio 
interessante e muito bonito. O salão nobre era uma obra de arte. Foi um absurdo abandonarem e depois demolirem... Poderiam ter utilizado para outros fins". 199

As obras do quarto e atual prédio da Santa Casa, localizado nos campos do Jabaquara, foram iniciadas na década de 1930, mas a inauguração só aconteceu em 2 de julho de 1945, com a presença do presidente Getúlio Vargas. Com capacidade para 1400 leitos, o hospital era um dos maiores e mais bem equipados da época. Atualmente, com 700 leitos ativos, ainda é considerado um dos maiores e mais completos do País. ${ }^{200}$

O discurso empolgado do presidente Getúlio Vargas durante a inauguração do hospital foi reproduzido no jornal $A$ Tribuna: "Quando for feita a história da filantropia no Brasil, ninguém deixará de reconhecer a indiscutível primazia da Santa Casa de Misericórdia de Santos, na organização e desenvolvimento das nossas iniciativas de assistência social". 201

\footnotetext{
${ }^{199}$ Depoimento do fotógrafo. 14/02/2006.

200 Henrique Seiji Ivamoto, A Fundação da Misericórdia e do Hospital. www.scms.org.br. Santos: Irmandade da Santa Casa de Misericórdia de Santos, 2006.

${ }^{201}$ Jornal $A$ Tribuna. Acontecimento exponencial na vida de Santos - A solenidade de inauguração do novo hospital da Santa Casa. Santos, 03 de julho de 1945, p.5.
} 


\subsection{3 - PAÇO MUNICIPAL (PALÁCIO JOSÉ BONIFÁCIO)}

Construído para abrigar a Prefeitura Municipal de Santos, que até então funcionava nos antigos casarões do Largo Marquês de Monte Alegre, o Palácio José Bonifácio teve suas obras iniciadas em 1937 e foi inaugurado a 26 de janeiro de 1939, como parte das comemorações do primeiro centenário da elevação de Santos à categoria de Cidade.

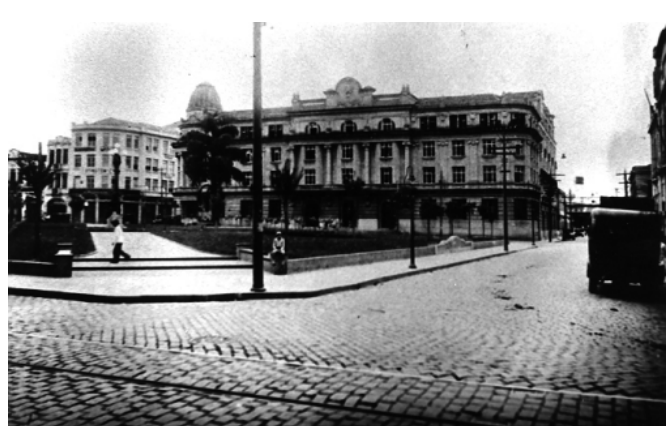

Praça Mauá sem o Paço Municipal. Santos. Início de 1937. Gelatina/prata, $120 \mathrm{~mm}, 6 \times 6 \mathrm{~cm}$. Acervo FAMS.

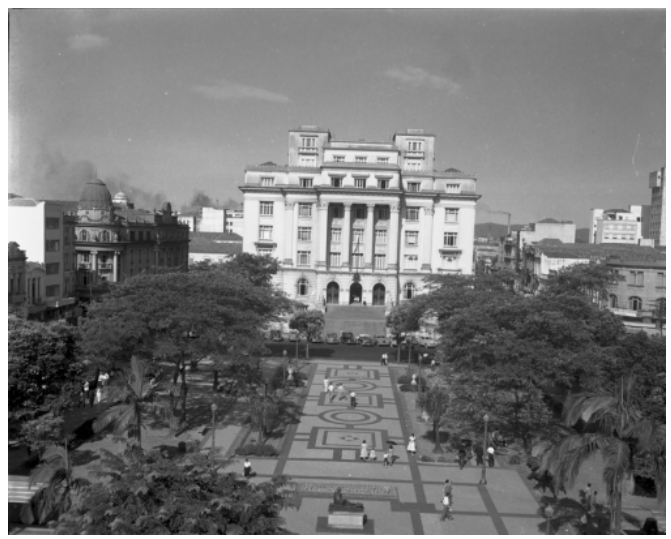

Praça Mauá e Paço Municipal. Santos. Década de 1970. Gelatina/prata, 35mm, $10 \times 15 \mathrm{~cm}$. Acervo José Dias Herrera.

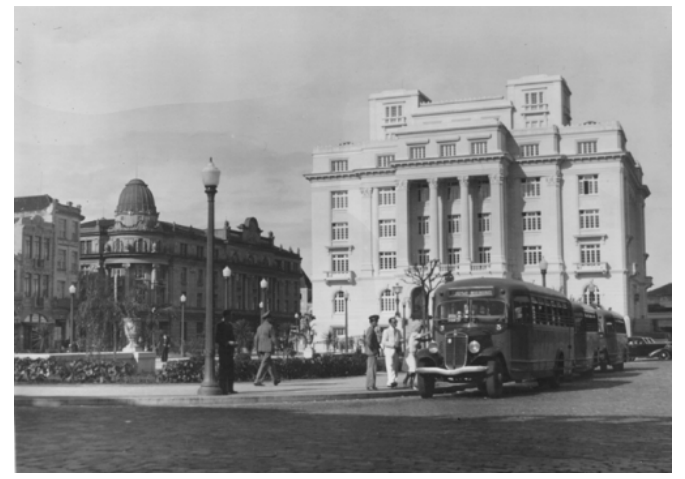

Praça Mauá e Paço Municipal. Santos. 1939. Gelatina/prata, $120 \mathrm{~mm}, 6 \times 6 \mathrm{~cm}$. Acervo FAMS.

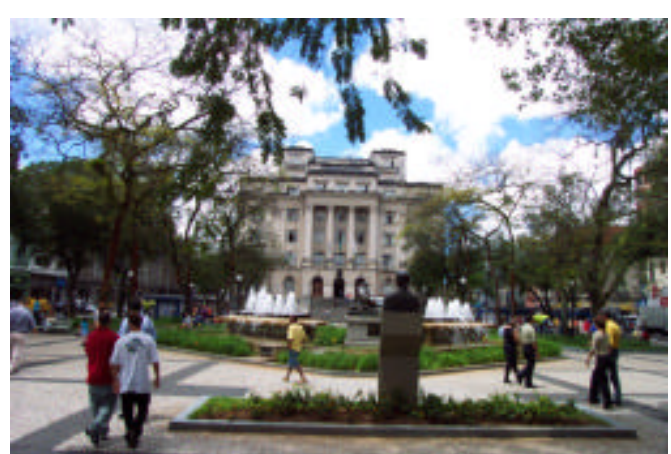

Praça Mauá e Paço Municipal. Percebe-se a existência de duas grandes fontes e canteiros no centro da praça. Santos. 11 de março de 2004. Imagem digital. Acervo Secretaria de Comunicação de Santos. 


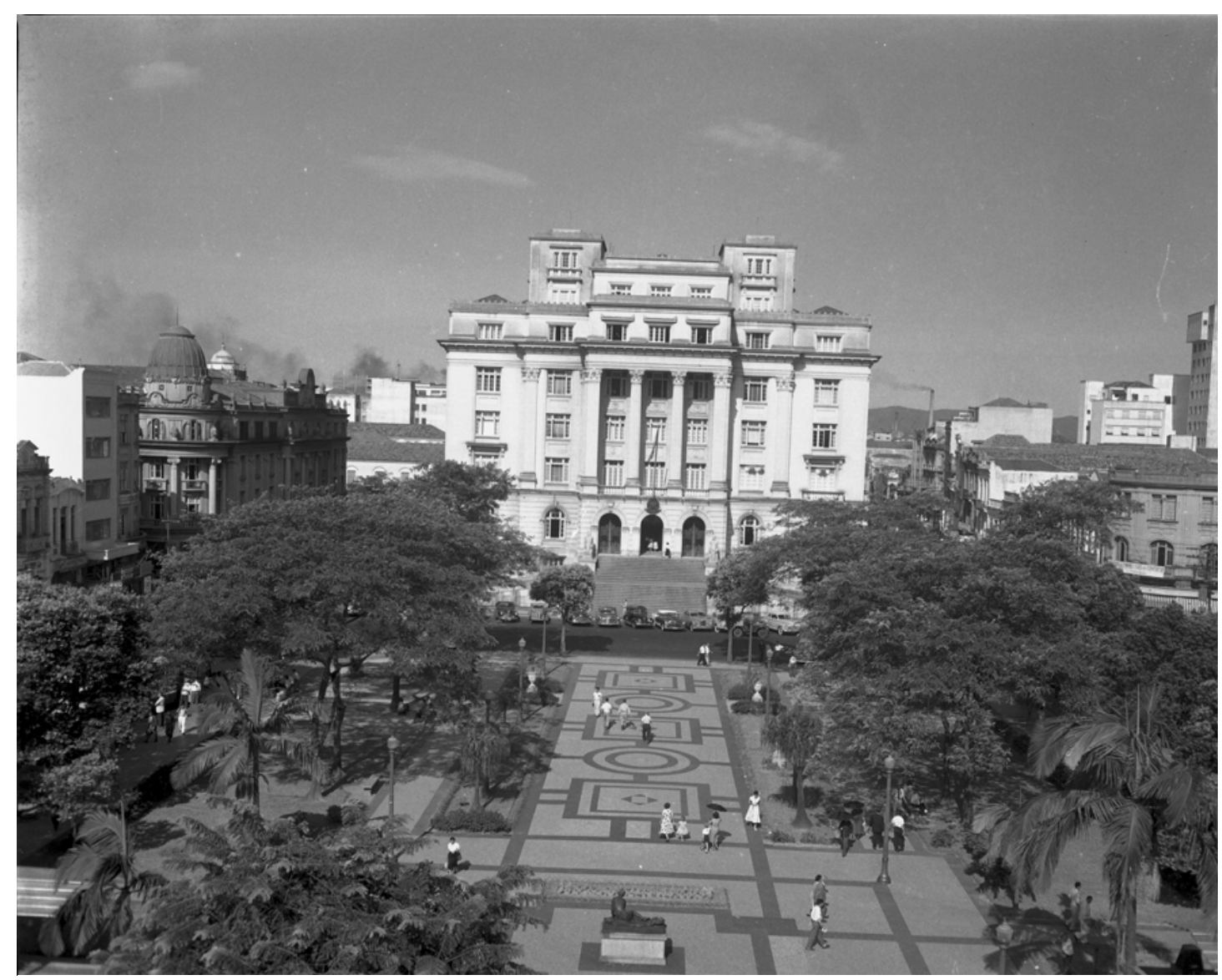

Praça Mauá e, ao fundo, o Palácio José Bonifácio, que abriga o Paço Municipal (Prefeitura), no Centro de Santos, na década de 1970.

Na imagem, percebemos que o Palácio José Bonifácio tem sete pavimentos e que o piso da Praça Mauá era todo em mosaico português. À esquerda, vemos o prédio dos Correios, que tem uma abóbada na parte de cima. Nota-se que o palácio e a praça eram separados por uma rua, que atualmente não existe mais. Também percebemos que o centro da praça era vazio, sem jardins, canteiros ou fontes, diferente de hoje em dia.

Herrera considera o local muito especial na sua vida e se emociona ao falar sobre o Paço Municipal:

Tenho um carinho especial pelo Paço. Estive presente no lançamento da sua pedra fundamental, acompanhei a sua construção e depois vivia lá dentro fotografando prefeitos, visitantes ilustres, reuniões... Além disso, trabalho nele há mais de 20 anos, né? [...] Lembro muito bem da praça sem o Paço; ela não era toda 
plana como é hoje; possuía rampas e a parte central era mais elevada, mas sempre foi muito bonita [...] Com a construção da Prefeitura, a praça ficou mais imponente, mais importante. ${ }^{202}$

Localizado na Praça Mauá, com seus vitrais, escadarias cercadas de pedra lavada, arcos, enormes colunas, lustres de cristal e pisos de mármore, o Paço Municipal impressiona pela sua beleza e imponência. Seu estilo arquitetônico segue os princípios do Período Eclético da Arquitetura, apresentando características grecoromanas, barrocas e neo-clássicas. Destacam-se dentro do edifício, além dos detalhes das portas, do piso, e do teto, o magnífico hall de entrada, o Salão Nobre Esmeraldo Tarquínio e a Sala Princesa Isabel. ${ }^{203}$

\footnotetext{
202 Depoimento do fotógrafo. 21/11/2006.

${ }^{203}$ Paço Municipal Diário Oficial de Santos, 10 de outubro de 2003, p.02. (coluna Memória Santista)
} 


\subsection{4 - BASÍLICA DE SANTO ANTONIO DO EMBARÉ}

A Igreja do Embaré, como é mais conhecida, era, no ano de 1875, uma capela que media 12 metros do altar até a porta, construída por Antonio Ferreira da Silva, o Visconde do Embaré. Com o seu falecimento em 1887, o lugar foi abandonado e, 25 anos depois, já estava em ruínas. Em 1912, o Padre Gastão de Moraes tornoutse reitor da Capela, tratando de promover a sua reforma, que ficou pronta em menos de um ano. Em 1915, a capela transformava-se numa igreja, reformada e ampliada, medindo agora $23 \mathrm{~m}$ de comprimento por $6 \mathrm{~m}$ de largura. Todos os anos celebravase o dia de Santo Antônio e aos domingos havia apenas uma missa às 10h30. Em 1922, os Frades Capuchinhos ampliaram novamente a igreja. ${ }^{204}$

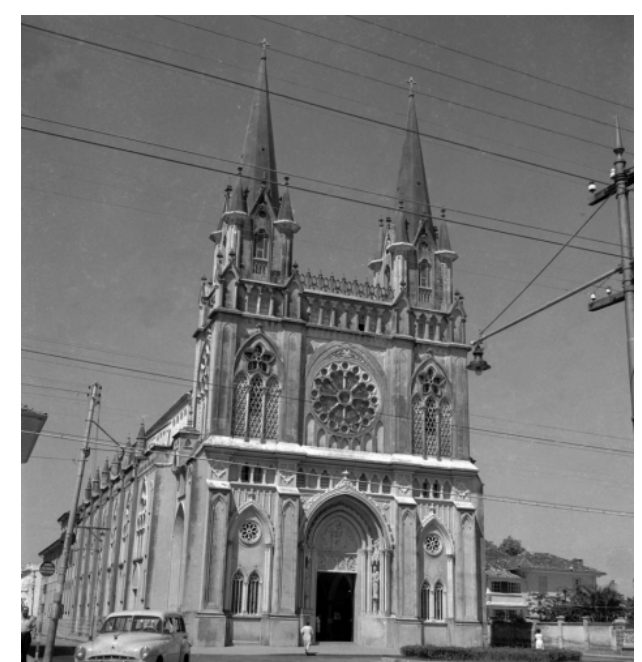

Basílica de Santo Antonio do Embaré. Santos. Década de 1950. Gelatina/prata, 120mm, $6 \times 9 \mathrm{~cm}$. Acervo José Dias Herrera.

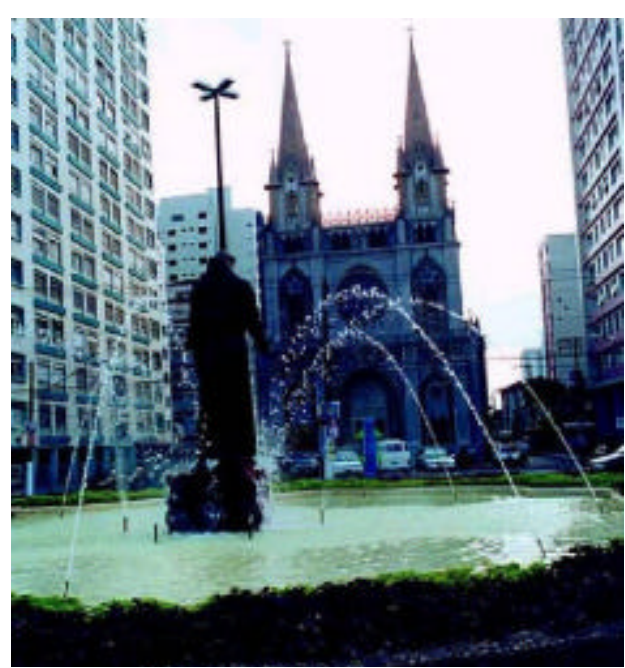

Basílica de Santo Antonio do Embaré. Santos. Setembro de 2002. Gelatina/prata, $35 \mathrm{~mm}$, $10 \times 15 \mathrm{~cm}$. Acervo Secretaria de Comunicação.

${ }^{204}$ Igreja do Embaré. Diário Oficial de Santos, 25 de julho de 2003, p. 02. Memória Santista. 


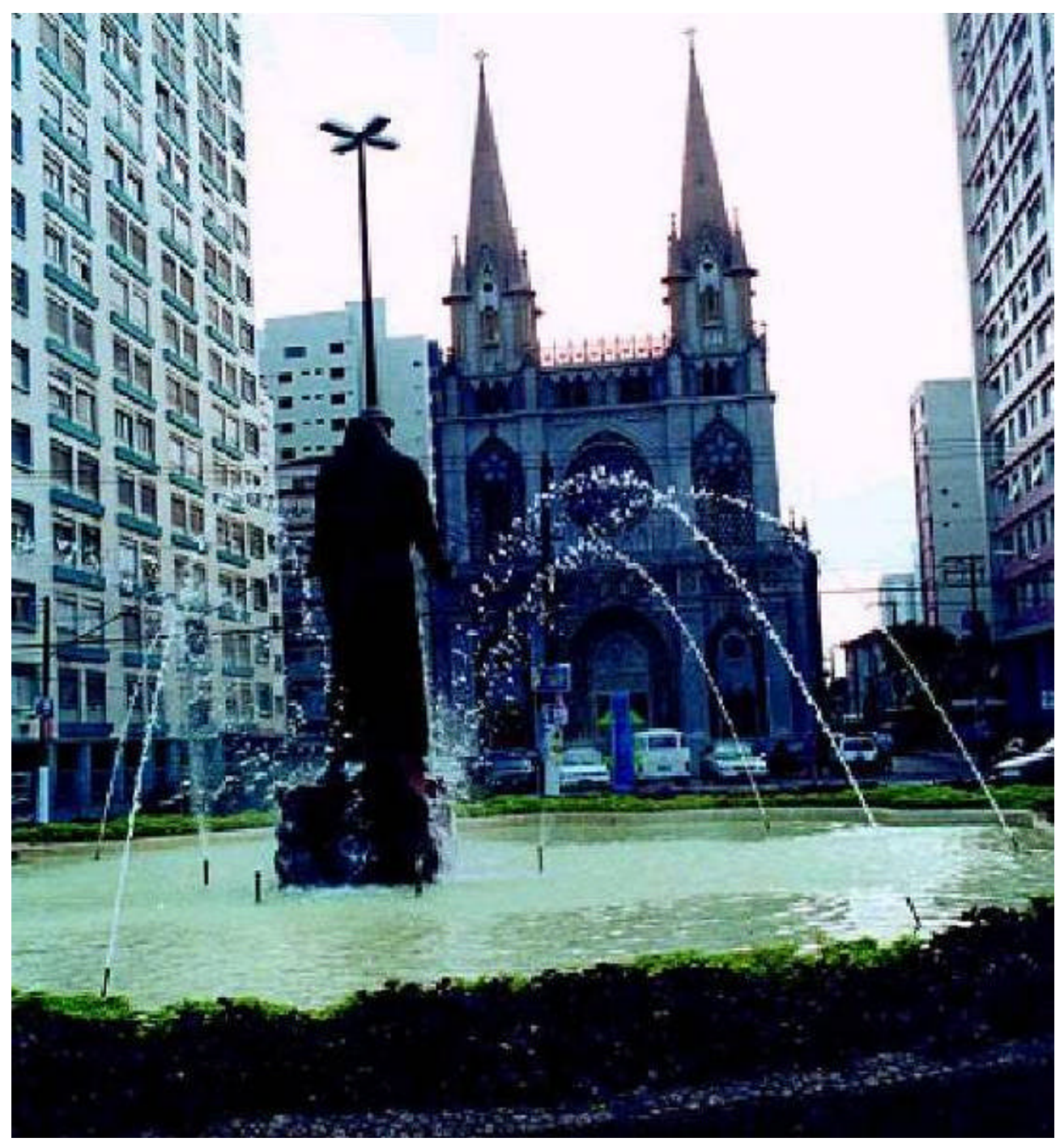

Basílica de Santo Antonio do Embaré e estátua de Santo Antonio, na orla da praia do Boqueirão, em 2002.

A imagem nos mostra, ao fundo, a Basílica de Santo Antonio do Embaré, localizada na Avenida Bartolomeu de Gusmão, 32, em frente à praia, entre edifícios residenciais. Em primeiro plano, em frente à igreja, vemos a parte traseira da estátua de Santo Antônio pregando aos peixes, que foi esculpida por Luiz Morone e inaugurada a 14 de outubro de $1956 .{ }^{205}$ A foto foi produzida em setembro de 2002 , mês de aniversário do bairro do Embaré.

A historiadora Wilma Therezinha descreve as características do edifício:

${ }^{205}$ LICHTI, Fernando Martins, Poliantéia Santista, 1996, p.180. 
A sua fachada compõe-se de três partes, superpostas horizontalmente. A parte inferior abre-se com um grande portal, ladeado pelas estátuas de São Pedro e São Paulo, encimado por um tímpano esculpido com as imagens de Nossa Senhora e o Menino Jesus junto à de São Francisco. Lateralmente, a primeira parte apresenta arcadas com aberturas de janelas em arco duplo, $\mathrm{Na}$ segunda parte, a do meio, destaca-se uma rosácea com vitrais, ladeada com dois arcos góticos. A terceira parte ou superior arremata a fachada com duas torres finalizadas em pirâmides com pináculos. As três partes formam um conjunto harmônico que realiza a idéia de ascensão para o Céu, para Deus. ${ }^{206}$

A basílica que conhecemos hoje, erguida no lugar da antiga capela, teve sua pedra fundamental lançada a 13 de julho de 1930. Em abril de 1931 já estavam revestidas as torres e, em 1934, o altar-mor foi inaugurado. Porém, as obras só foram concluídas no ano de 1946, realizando-se no dia 7 de dezembro a solenidade de sagração, pelo Bispo D. Idílio José Soares. No dia 13 de junho de 1949, o templo foi inaugurado. ${ }^{207}$ Recebeu o título de Basílica por decisão papal em 03 de novembro de $1952 .^{208}$

\footnotetext{
${ }^{206}$ ANDRADE, Wilma Therezinha F., Presença da Engenharia e Arquitetura - Baixada Santista, 2001, $\mathrm{p}_{207} 101$.

${ }^{207}$ Igreja do Embaré. Diário Oficial de Santos,, 25 de julho de 2003, p. 02. coluna Memória Santista.

${ }^{208}$ ANDRADE, Wilma Therezinha F., Presença da Engenharia e Arquitetura - Baixada Santista, 2001, p.101.
} 


\subsection{5 - BOLSA OFICIAL DE CAFÉ}

O prédio da Bolsa Oficial de Café é um exemplo da arquitetura do ecletismo, com cúpulas de cobre, esculturas, vitrais, mosaicos de mármore, colunas de granito. $\mathrm{Na}$ torre, foram construídas quatro figuras, representando a Agricultura, a Indústria, a Navegação e o Comércio. Na entrada, na parte de cima, as duas peças do frontão representam Mercúrio, deus do comércio, e Ceres, deusa da cultura. ${ }^{209}$

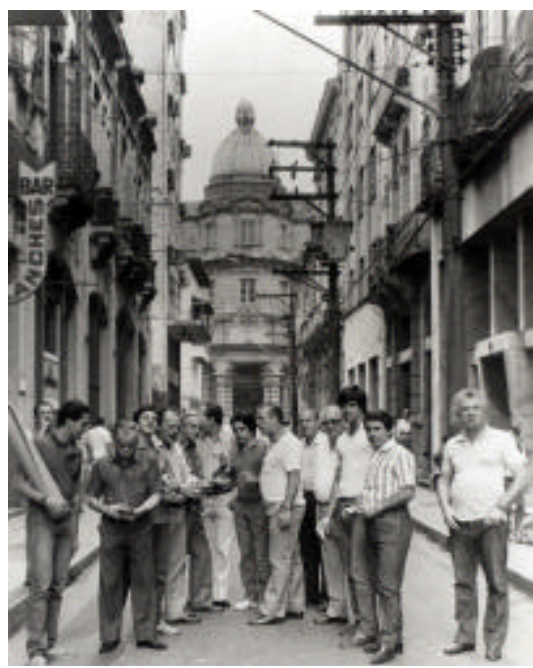

Trabalhadores do Centro conversando na Rua XV de Novembro, tendo ao fundo a entrada da Bolsa Oficial de Café. Década de 1970. Gelatina/prata, $120 \mathrm{~mm}, 6 \times 9 \mathrm{~cm}$. Acervo José Dias Herrera.

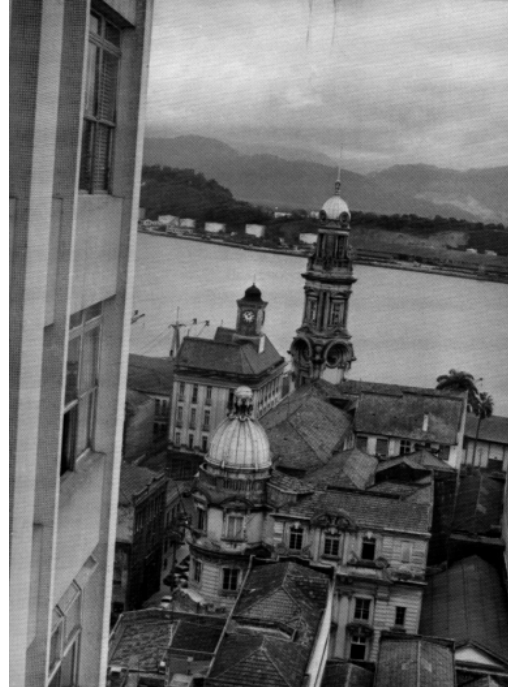

Edifício da Bolsa Oficial de Café visto de cima. Reprodução da publicação $\mathrm{O}$ palácio do café.

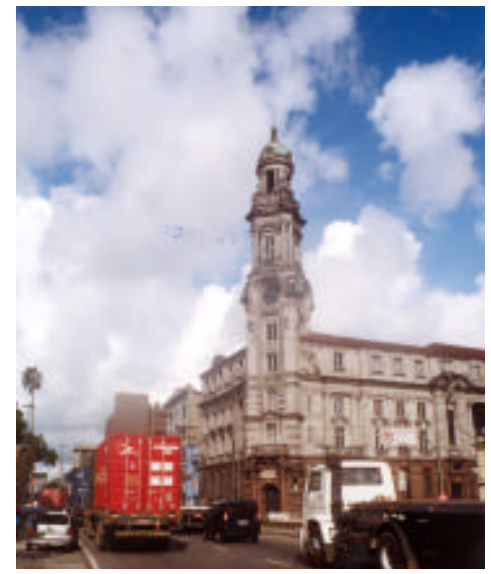

Torre traseira da Bolsa oficial de Café Com 40 m de altura, está erguida ao canto da Praça Azev edo Júnior e da Rua Frei Gaspar.. Santos. 20 de junho de 2007. Gelatina/prata, 135mm $10 \times 15 \mathrm{~cm}$. Acervo José Dias Herrera.

${ }^{209}$ BARBOSA, Gino Caldatto, O palácio do café, 2004, p. 64 e 82. 


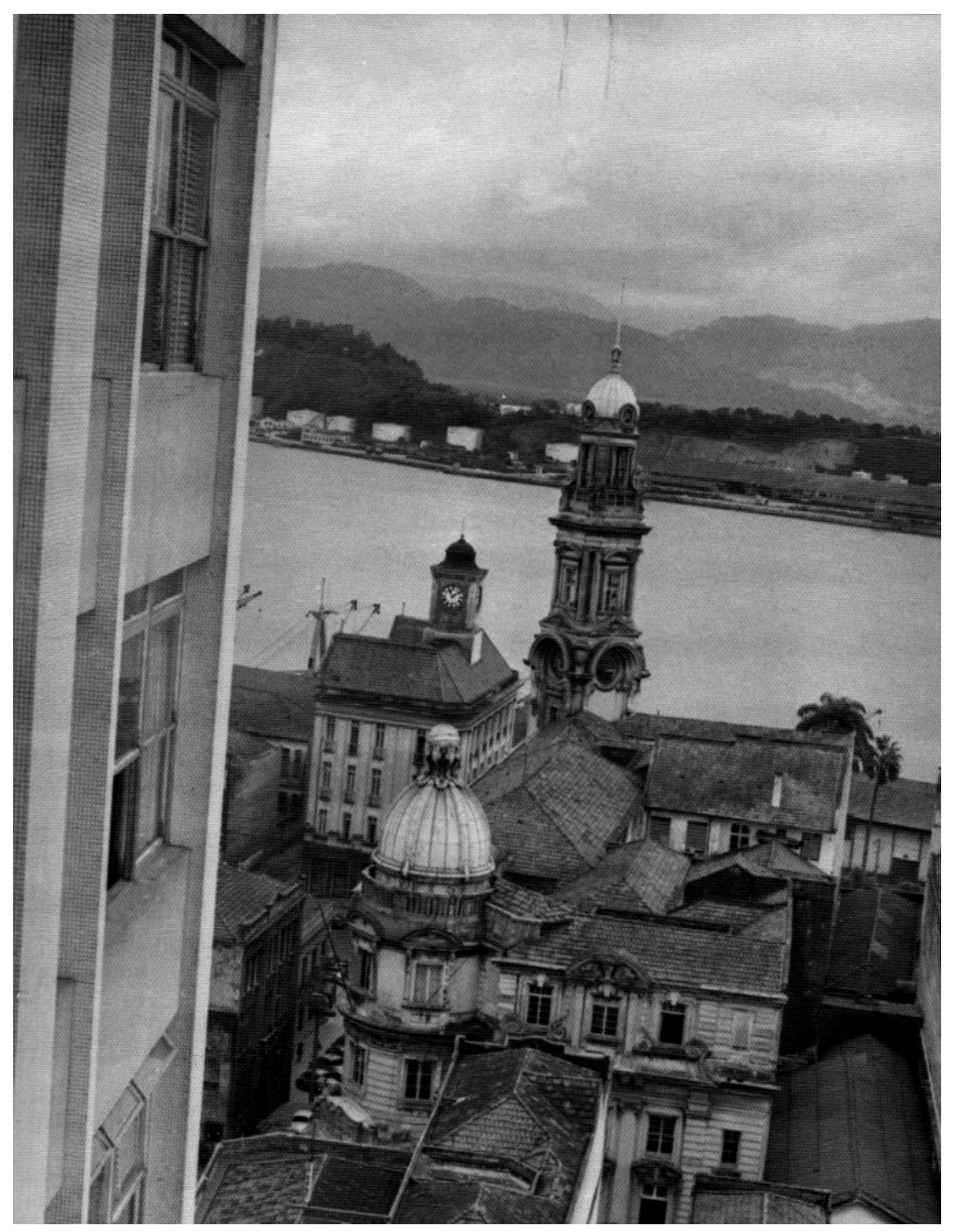

Prédio da Bolsa Oficial de Café visto de cima.

$\mathrm{Na}$ imagem percebemos que o pórtico de entrada do edifício fica na esquina formada pelas ruas XV de Novembro e Frei Gaspar - o antigo Quatro Cantos, lugar tradicional da Cidade. A torre do relógio, de $40 \mathrm{~m}$ de altura, está voltada para o Porto, na esquina das ruas Frei Gaspar e Tuiuti. Tais referências físicas exerceram grande influência sobre a concepção arquitetônica do edifício, em que se buscou a valorização formal das esquinas, demarcadas por balizas verticais da torre e da cúpula, como sinalização visual dos acessos principais. ${ }^{210}$

\footnotetext{
${ }^{210}$ BARBOSA, Gino Caldatto, O palácio do café, 2004, p.78.
} 
José Herrera ressalta que o prédio da Bolsa de Café sempre foi ponto de encontro dos santistas:

Logo que eu comecei a fotografar (final de década de 1930), a maioria das pessoas de Santos trabalhava no Centro e parava para bater um papinho em frente à Bolsa; a rua ficava lotada e o trânsito chegava a parar [...] Também funcionava no prédio um restaurante e eu mesmo cheguei a almoçar lá diversas vezes; era bastante movimentado e bem frequentado[...] Até hoje, a Bolsa é uma referência para quem quer se encontrar aqui no Centro, sem falar que virou um ponto turístico muito conhecido. ${ }^{211}$

Símbolo de uma época em que o café assumiu um lugar de supremacia dentro da economia nacional, a Bolsa Oficial de Café foi criada junto com a Câmara Sindical dos Corretores de Café de Santos, a 14 de julho de 1914, com o objetivo de centralizar, organizar e controlar as operações do mercado cafeeiro. Porém, com o início da I Guerra Mundial, só puderam ser instaladas em maio de 1917, num salão alugado na esquina das ruas XV de Novembro e do Comércio. Dentre outras coisas, a lei de criação previa a cobrança de uma taxa para a construção de um prédio destinado ao seu funcionamento.

A pedra fundamental do novo edifício foi lançada em dia 27 de abril de 1920 e, em 07 de setembro de 1922, o prédio da Bolsa Oficial de Café foi oficialmente inaugurado pelo então presidente Washington Luiz. Com a quebra da Bolsa de Nova York, em 1929, a economia cafeeira do Brasil foi afetada e a Bolsa foi desativada em 1937. No ano de 1942, voltou a operar como Bolsa de Café e Mercadorias, mas os famosos pregões terminaram na década de 1950. ${ }^{212}$

Com o fim dos pregões, o prédio começou a ser ocupado por repartições do Estado e entrou em processo de acelerado abandono. Em 1981, o tombamento pelo

\footnotetext{
${ }^{211}$ Depoimento do fotógrafo. 05/04/2007.

${ }^{212}$ LICHTI, Fernando Martins, Poliantéia Santista, p.177.
} 
Conselho de Defesa do Patrimônio Histórico, Arqueológico, Artístico e Turístico (Condephaat) garantiu que não fosse descaracterizado. José Herrera recorda com tristeza da época em que o edifício da Bolsa apresentava péssimo estado de conservação:

A situação estava crítica mesmo. Tinha vazamentos, instalações quebradas, infiltrações... Lembro também de alguns pisos rachados, vitrais quebrados, do elevador que não funcionava, e chegaram até a interditar os andares de cima. Eu fiquei muito chateado mesmo [...] O importante é que tudo foi restaurado e hoje está aí pra todo mundo admirar. ${ }^{213}$

O edifício começou a ser restaurado pelo Estado em 1996 e foi reaberto em 1998. Atualmente, abriga o Museu dos Cafés do Brasil e conserva a sala de pregões com a mesma mobília em jacarandá usada pelos antigos corretores e as três telas de Benedito Calixto retratando Santos nos anos de 1545, 1822 e 1922. No lugar existe ainda o Centro de Preparação do Café, que ministra cursos sobre o tema, cafeteria, biblioteca e acervo de objetos ligados ao produto. ${ }^{214}$

\footnotetext{
${ }^{213}$ Depoimento do fotógrafo. 05/04/2007.

214 Jornal Diário Oficial de Santos. Bolsa do Café completa 85 anos. Santos, 07 de setembro de 2007, p.12.
} 


\subsection{6 - TEATRO GUARANI}

O Teatro Guarani foi inaugurado no dia 07 de dezembro de 1882 e colocou Santos na rota mundial do teatro. Estrelas como a francesa Sarah Bernhardt, uma das mais famosas atrizes da época, se apresentaram em seu palco. O Guarani teve grande participação na vida artística, cultural, política e social da Cidade, além ter concentrado numerosas campanhas abolicionistas. Manteve-se no auge até meados da década de 20, quando entrou em decadência. Virou cinema e logo passou a atrair amantes de filmes pornográficos. Em 1981, foi consumido por um incêndio, ficou em ruínas ${ }^{215}$ e hoje está sendo restaurado com recursos da Lei Rouanet.

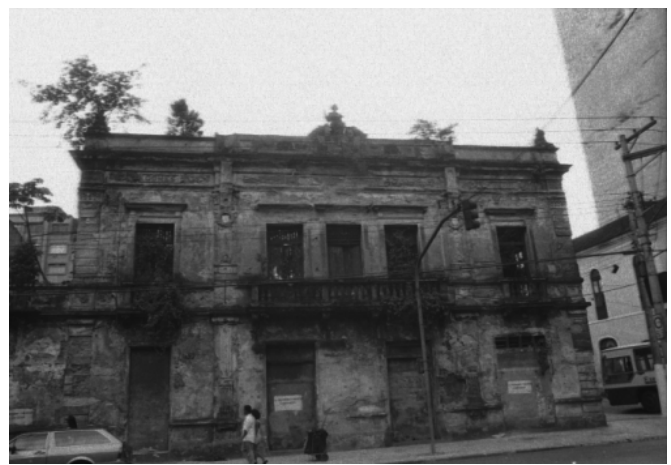

Ruinas do Teatro Guarani. Centro de Santos, 1991. Gelatina/prata, $24 \times 36 \mathrm{~cm}$. Acervo FAMS

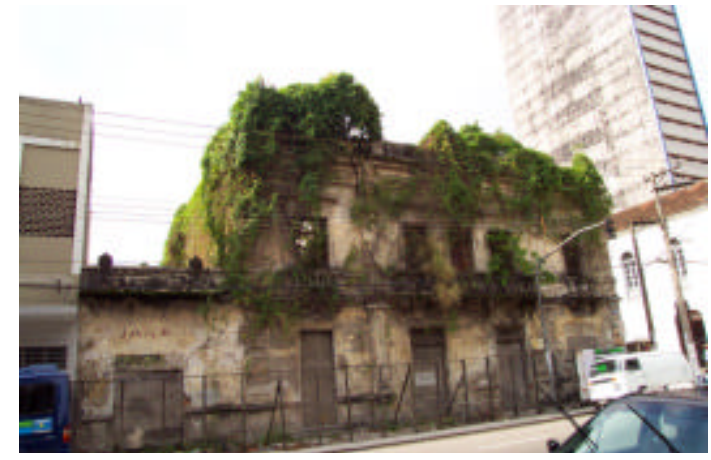

Ruinas do Teatro Guarani, com sinais de vegetação intensa tomando conta do que restou. Centro de Santos, março de 2003. Imagem Digital, Acervo Secretaria de Comunicação de Santos.

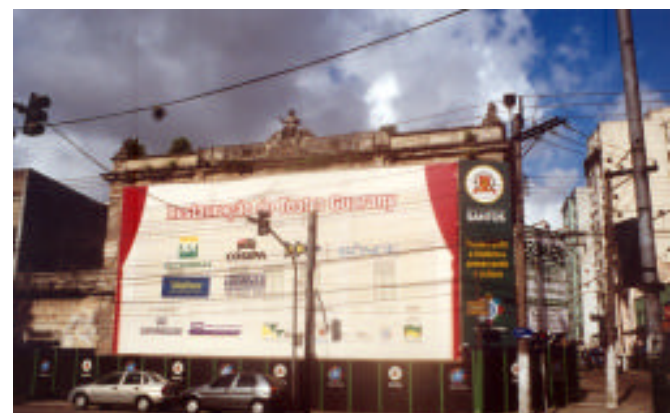

Ruinas do Teatro Guarani, com tapumes e a placa com os nomes das empresas que estão patrocinando as obras de restauro. Centro de Santos, 20 de jane iro de 2007 . Gelatina/prata, $35 \mathrm{~mm}, 10 \times 15 \mathrm{~cm}$. Acervo particular Iosé Dias Herrera.

\footnotetext{
${ }^{215}$ Fernando Martins Lichti, História de Santos - Poliantéia Santista, p.61.
} 


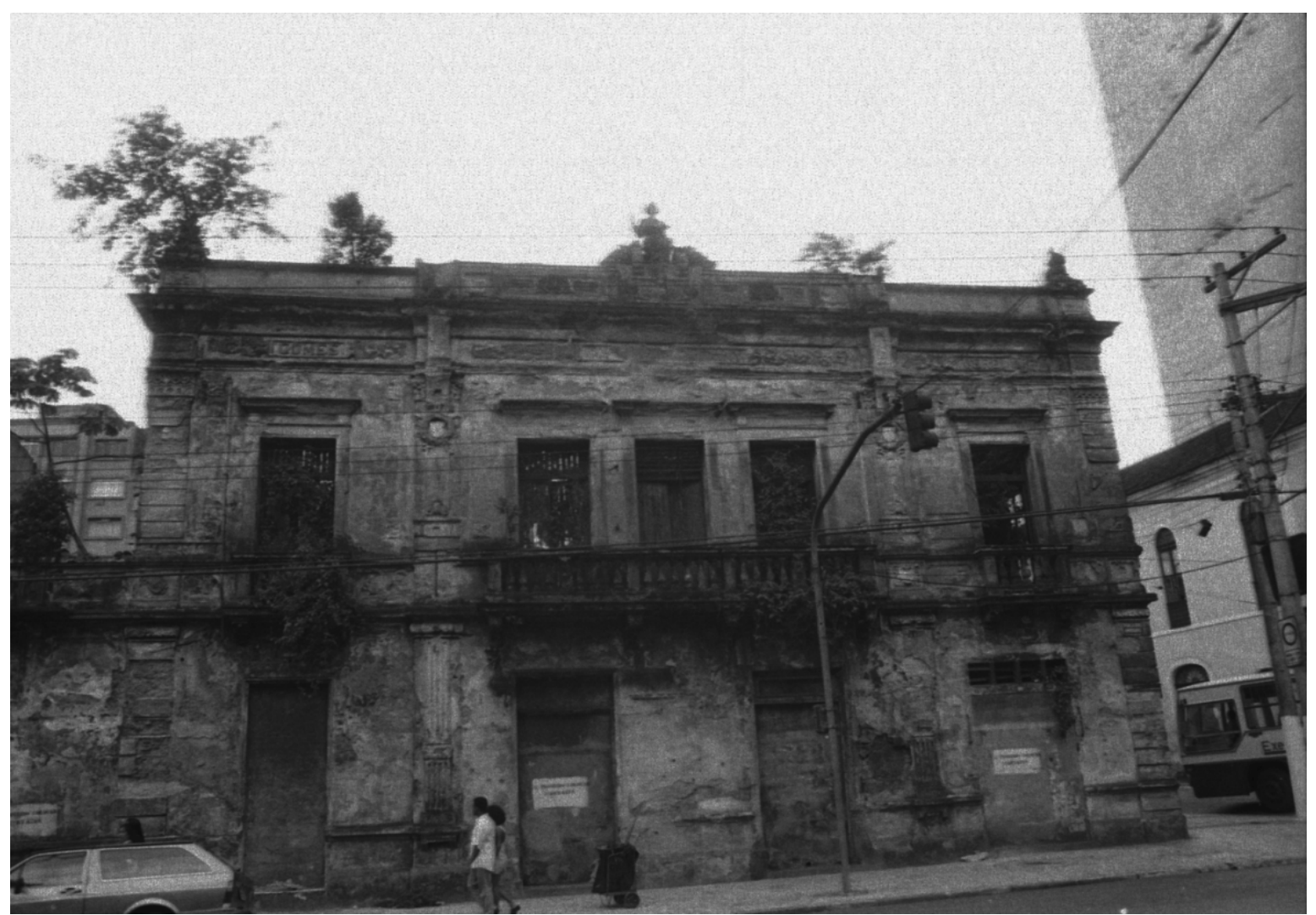

Ruínas do antigo Teatro Guarani, localizado na Praça dos Andradas, esquina com a Rua Amador Bueno, em 1991.

Como mostra a fotografia, do edifício original, só restam as paredes da fachada e da lateral da Rua Amador Bueno. Toda a área interna parece um grande pátio, que está tomado pela vegetação, já visível na fachada. O edifício foi construído em estilo neoclássico e, após reformas ocorridas em 1910, passou a ter estilo eclético. O fotógrafo José Herrera comenta:

Lembro do Guarani bem arrumado; era muito bonitinho. Cheguei a assistir alguns filmes lá. Até a década de 1930, era o teatro mais popular da Cidade, o mais conhecido. Depois, quando apareceu o Coliseu, ele foi sendo deixado de lado. O Coliseu tomou conta e o Guarani passou a ser mal freqüentado. ${ }^{216}$

Fernando Martins Lichti relembra como surgiu o Guarani:

${ }^{216}$ Depoimento do fotógrafo. 27/10/ 2005. 
Em 1880 foi formada uma comissão, objetivando a construção de um novo teatro[...] Com o apoio de toda a população e da imprensa, foram subscritas 512 ações e com os recursos financeiros obtidos foi adquirido o terreno [...] Sua escritura foi lavrada a 5 de janeiro de 1881 e sua inauguração aconteceu em 7 de dezembro de $1882 .{ }^{217}$

Felizmente, depois de anos de indecisão e contrariando as previsões de demolição, a Prefeitura Municipal comprou o imóvel em 30 de junho de 2003 e está realizando o restauro com recursos obtidos por meio da Lei Rouanet para transformá-lo em escola de teatro (formação de atores) e música - mantendo a essência da destinação de uso que teve no passado - e ampliando as opções culturais no Centro Histórico. ${ }^{218}$ Herrera vibra com esta possibilidade:

Vai ser ótimo trazerem de volta o Guarani, como já está acontecendo com o Coliseu. Santos precisa disso mesmo. Acho que a Cidade até pode resgatar um pouquinho do glamour que já teve no passado, né? Espero estar vivo para poder ver isso. ${ }^{219}$

\footnotetext{
217 LICHTI, Fernando Martins, História de Santos - Poliantéia Santista, 1996, p.61.

218 Diário Oficial de Santos. Prefeitura compra Teatro Guarany. 30 de junho de 2003, p.16.

${ }^{219}$ Depoimento do fotógrafo. 27/10/2005.
} 


\subsection{7 - TEATRO COLISEU}

O Coliseu Santista passou por três fases distintas, mas sempre funcionou no mesmo local. Quando foi inaugurado (1896), era um ginásio de madeira e suas atividades eram de velódromo ${ }^{220}$ e botequim. Em 1909, transformou-se num teatro, recebendo espetáculos. Em 1923, foi adquirido pelo comendador Manuel Freixo. Reinaugurado a 21 de junho de 1924, passou a ser considerado um dos mais modernos e luxuosos teatros do Brasil, sendo que em seu palco pisaram grandes nomes como Vicente Celestino, Cacilda Becker, Procópio Ferreira, Carmem Miranda e tantos outros. ${ }^{221}$

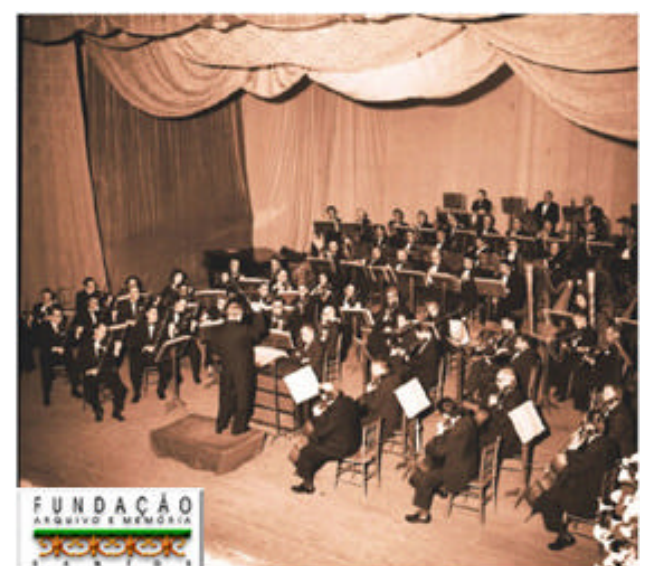

Apresentação do maestro Heitor Villa Lobos no Coliseu. Santos, 1ำ de outubro de 1958. Reprodução do calendário 2005 da $\mathcal{F A M S}$.

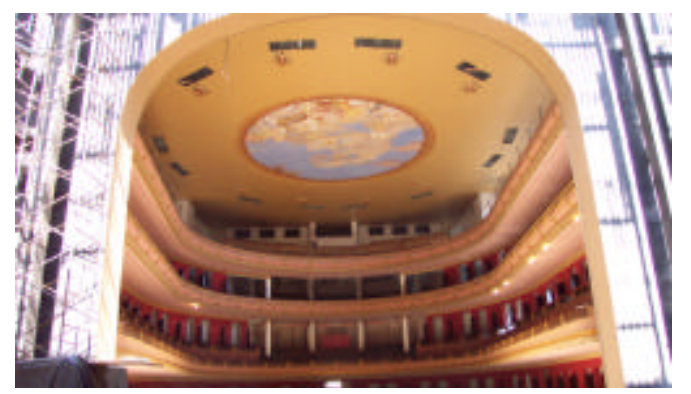

Vista interna do Teatro Coliseu, que estava sendo restaurado. Vê-se a platéia, com os seus camarotes ao centro, frisas nas laterais e a arquibancada no último andar. $\mathcal{N}$ o te to, a obra Alegoria à Música, do pintor italiano Fonzari. Santos, 27 de fevereiro de 2000. Imagem digital. Acervo Secretaria de Comunic ação de Santos.

\footnotetext{
${ }^{220}$ Pista para corridas de bicicletas

${ }^{221}$ LICHTI, Fernando Martins, História de Santos - Poliantéia Santista, 1996, p. 61.
} 


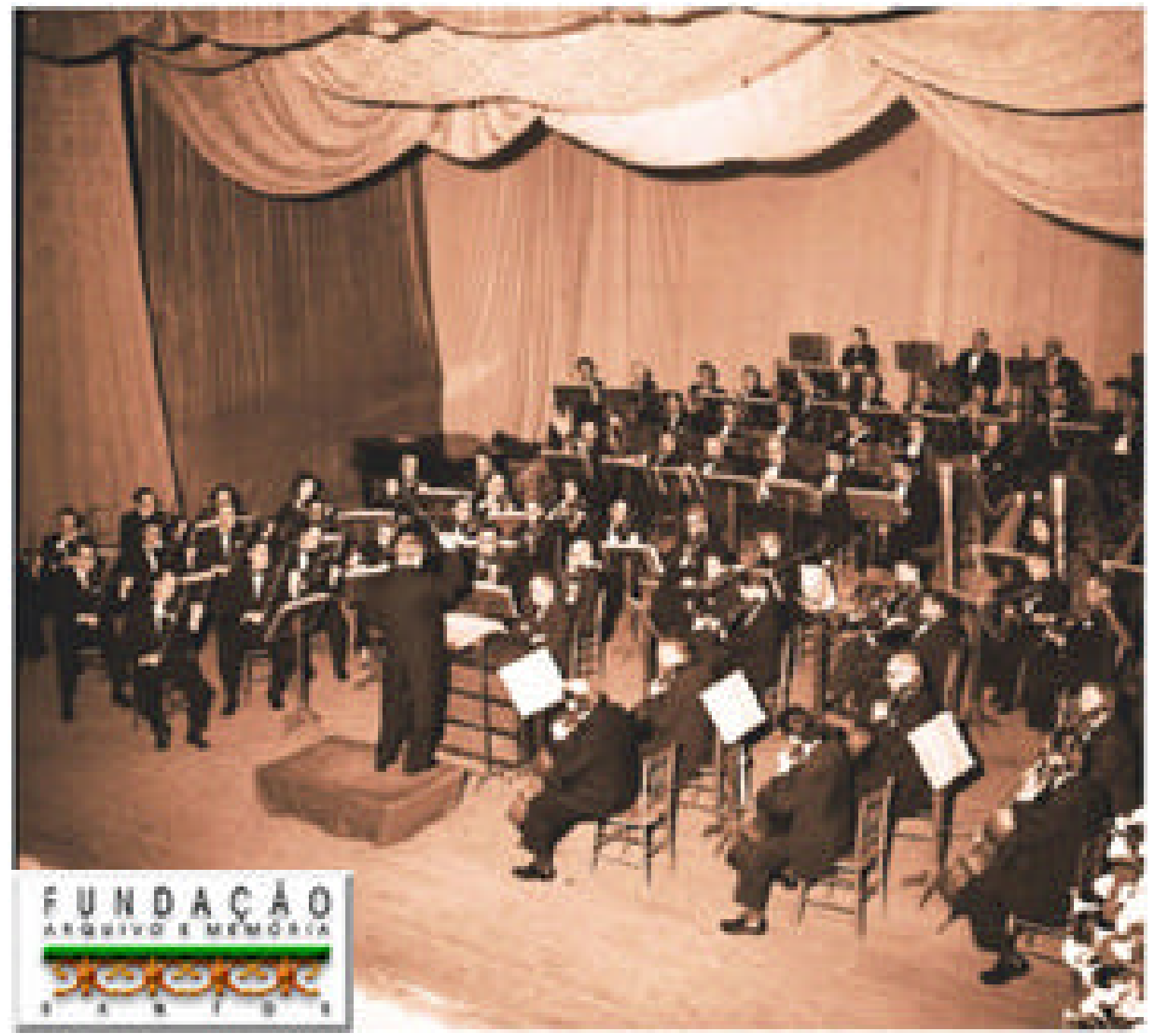

Apresentação do maestro Heitor Villa Lobos, um dos maiores compositores do século $X X$, no Teatro Coliseu, em companhia da Orquestra Sinfônica Municipal de São Paulo, em $1^{\circ}$ de outubro de 1958.

Durante a apresentação, foram executadas obras do próprio maestro, que aparece de pé, ao centro, e o "Poema de Itabira", de Carlos Drummond de Andrade. Quanto às apresentações no Teatro Coliseu, Herrera lembra:

Acontecia de tudo: orquestras, peças de teatro, apresentações de dança, formaturas, óperas [...] Quando a apresentação era de orquestra, os músicos se apresentam no palco mesmo. Quando as apresentações eram de teatro ou dança, os músicos ficavam no fosso $^{222}[\ldots]$ Mas eu nunca assitia o espetáculo inteiro, não dava tempo. Além disso, não podia ficar tirando foto por causa da fumaça do magnésio e do barulho que fazia [...] Muita gente famosa se

${ }^{222}$ Espaço entre o palco e a platéia, na altura da platéia, onde cabiam cem músicos. 
apresentou lá, mas o espetáculo mais bonito que fotografei nem era famoso, foi um bailado francês. ${ }^{223}$

E Fernando Martins Lichtti completa:

Com excelente acústica, ricos lustres de cristais, finíssima pintura filetada, escadarias de mármore, cortinas de veludo, platéia em aclive, amplo hall com colunas de granito e imponente fachada, o novo Colyseu era um majestoso teatro, classificado entre os melhores do Brasil. $^{224}$

Porém, apesar de sua grandiosidade, o Teatro Coliseu entrou em decadência. Na década de 1950, a parte dos fundos do teatro foi vendida para a construção de um posto de gasolina, atingindo os camarins e outros anexos do palco. Na mesma ocasião, o hall de entrada foi dividido para construção de lojas comerciais. Nessa época, o Coliseu já funcionava mais como cinema do que como teatro. Em 1982, o tombamento pelo Condephaat impediu sua demolição e, em 1992, o teatro foi desapropriado pela Prefeitura Municipal de Santos, que deu início às obras de restauração do imóvel. ${ }^{225}$

Após mais de 30 anos desativado e 12 anos de reformas, ao custo de $R \$ 20$ milhões, bancados pelo Poder Público e iniciativa privada, o Teatro Coliseu foi reinaugurado a 25 de janeiro de 2006, apresentando um trabalho de restauro impressionante pelos detalhes: escadarias em mármore, afrescos nas paredes internas, desenhos de anjos no teto, o magnífico piso, o corrimão de scalole ${ }^{226}$ e até a decoração, cuidadosamente pesquisada de modo a recriar a original. ${ }^{227}$

\footnotetext{
223 Depoimento do fotógrafo. 07/02/2007.

224 LICHTI, Fernando Martins, História de Santos - Poliantéia Santista, 1996, p. 61.

225 LICHTI, Fernando Martins, História de Santos - Poliantéia Santista, 1996, p. 61.

226 Tipo de pintura que imita o granito original da época da inauguração, em 1924.

227 Revista Beach \& Co, Coliseu volta a encantar. Santos, março de 2006, p. 8, 9 e 10.
} 


\subsection{8 - CASARÕES DO VALONGO}

Mesmo estando hoje em ruínas, o que resta dos antigos Casarões do Valongo revela a imponência da arquitetura da época. Em estilo neoclássico, construídos nos anos de 1867 e 1872 pelo comendador Manoel Joaquim Ferreira Neto, foram considerados os maiores da província de São Paulo e abrigaram a Prefeitura (Intendência, naquele tempo) e a Câmara Municipal, até estas serem transferidas para o Palácio José Bonifácio, na Praça Mauá, em 1939. ${ }^{228}$

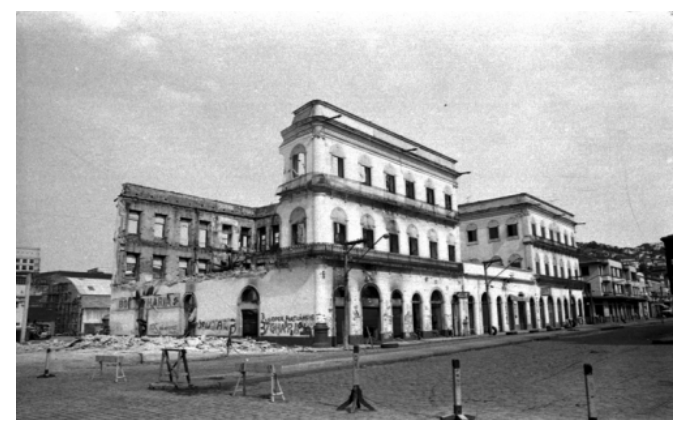

Casarões do Valongo, Centro de Santos, 1986. Gelatina/prata, $35 \mathrm{~mm}, 10 \times 15 \mathrm{~cm}$. Acervo FAMS.

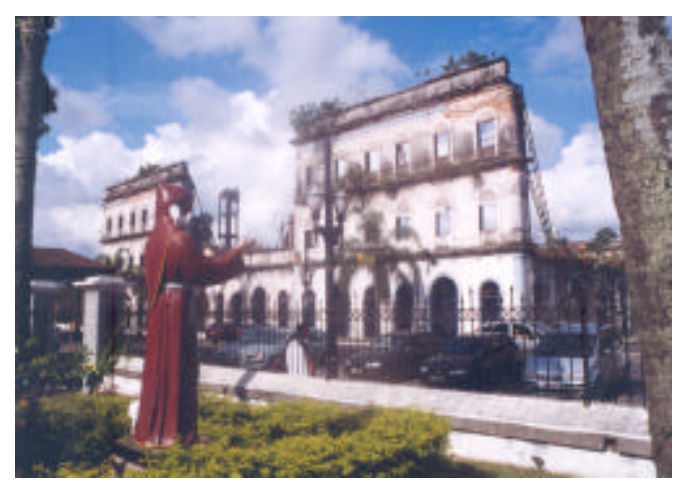

Ruínas dos Casarões do Valongo vistas de frente Centro de Santos, 20 de janeiro de 2007. Gelatina/prata, $35 \mathrm{~mm}, 10 \times 15 \mathrm{~cm}$. Acervo particular Iosé Dias Herrera.

${ }^{228}$ ANDRADE, Wilma Therezinha F., Presença da Engenharia e Arquitetura - Baixada Santista, 2001, p. 78 e 79. 


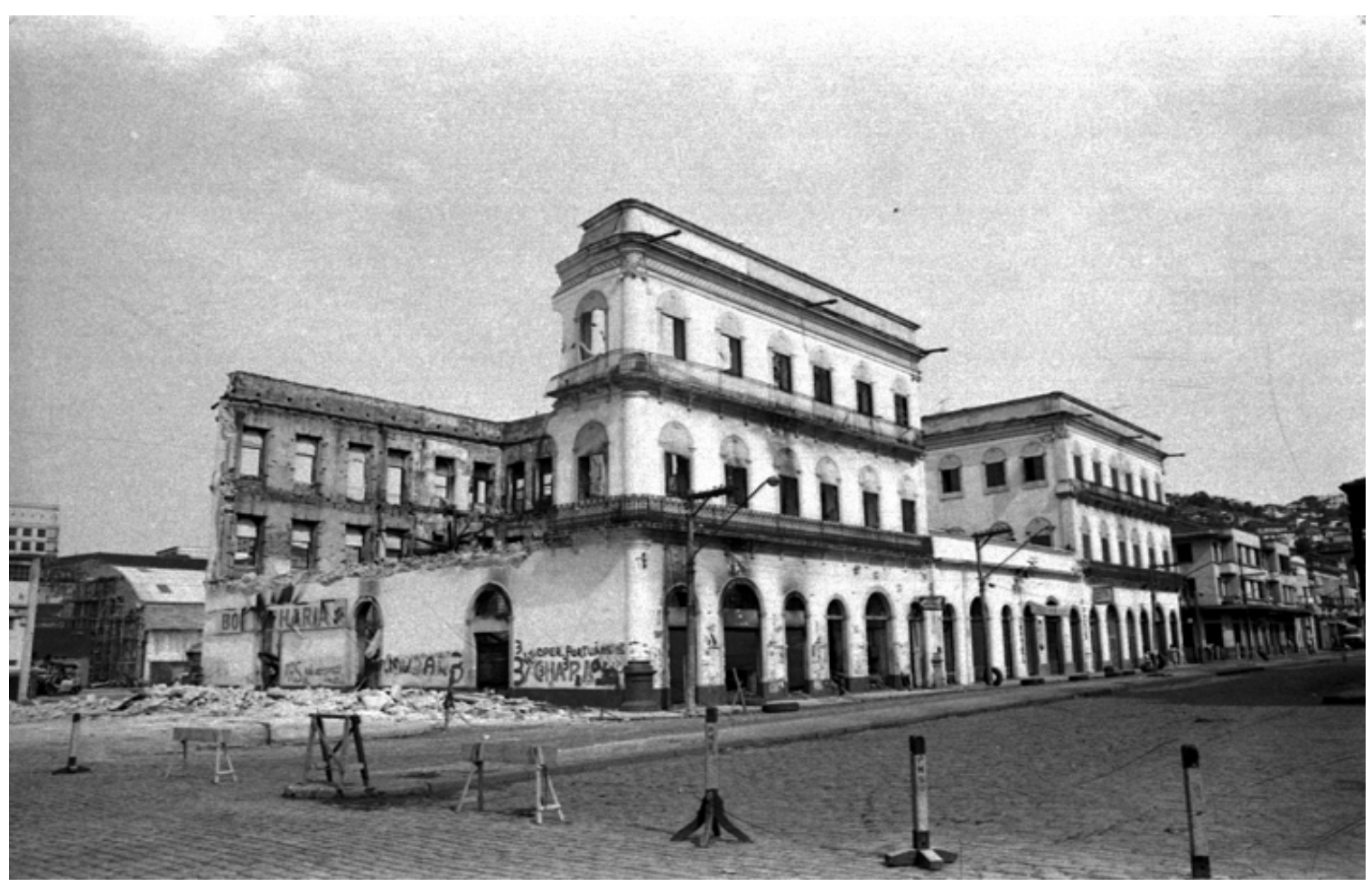

Casarões do Valongo em 1986.

A foto mostra os casarões no ano de 1986, após o incêndio que derrubou a parede lateral do prédio esquerdo e o deixou totalmente oco. Na ocasião, o edifício da direita ainda mantinha todas as paredes, que seriam abaladas após outro incêndio, em 1988. Com o passar dos anos, as outras paredes foram caindo e hoje só restam as duas fachadas e a parede traseira do prédio esquerdo. José Herrera lembra do tempo em que a Prefeitura ocupava um dos prédios:

O primeiro prefeito que eu conheci fotografando, o Gomide Ribeiro ${ }^{229}$, foi dentro de um dos casarões - o mais próximo do Porto, da esquerda. O prédio era imponente, mas o elevador estava sempre encrencado e eu tinha que subir pelas escadas. ${ }^{230}$

Tombado em 1983 pelo Conselho de Defesa do Patrimônio Histórico, Arqueológico, Artístico e Turístico (Condephaat), o conjunto teve seu valor histórico

\footnotetext{
229 Antonio Gomide Ribeiro dos Santos, prefeito de Santos de 17/01/1938 a 14/07/1938 e de 01/07/1941 a 31/08/1945.

${ }^{230}$ Depoimento do fotógrafo. 07/08/2006.
} 
reconhecido, porém, ainda assim, sofreu um incêndio em 1985 e dois desabamentos, em 1986 e 1988. No ano de 1991, os prédios foram tombados pelo CONDEPASA (Conselho de Defesa do Patrimônio Cultural de Santos). ${ }^{231}$

Finalmente, em agosto de 2007, após anos de abandono e indefinições quanto ao destino do que restou dos Casarões do Valongo, a Prefeitura de Santos anunciou a construção, no local, do Museu Pelé. O projeto prevê o restauro das fachadas dos imóveis e a construção interna de três blocos modernos, que abrigarão lojas, café, espaços para exposições temporárias e permanentes, auditório em forma de esfera para exibição de filmes, salas para a administração e, claro, o acervo do Rei do Futebol, composto por chuteiras, troféus, camisas, fotografias e vídeos. ${ }^{232}$

\footnotetext{
${ }^{231}$ Jornal Boqueirão News, coluna Almanaque Santista, Os Casarões do Valongo. Santos, 23 de agosto de 2003, p.04.

${ }^{232}$ Jornal da Orla, O gol definitivo. Santos, 25 e 26 de agosto, p. 04 e 05.
} 


\subsection{Social e Política}

Por conta do Complexo do Porto de Santos e do pólo industrial de Cubatão, estas cidades da Baixada Santista sempre receberam a visita de presidentes e governadores eleitos, ditadores militares e até de líderes estrangeiros. Além disso, Santos sempre teve uma tradição de contestação política, que ficou evidente durante o regime militar, quando a Cidade foi considerada área de segurança nacional e perdeu a sua autonomia política, em 1969.

Fora as ilustres visitas dos chefes de Estado, Santos também passou por processos eleitorais municipais muito disputados e cheios de conflitos e surpresas. Uma história política com direito a capítulos de cassação, renúncia e até morte.

Nos últimos 70 anos, José Herrera acompanhou de perto a trajetória política de toda a região, mas sempre soube manter a sua isenção nos momentos em que esteve trabalhando. Por isso, nem mesmo durante a ditadura encontrou problemas para realizar o seu trabalho. 


\subsection{1 - JUSCELINO KUBITSCHEK}

O político Juscelino Kubitschek de Oliveira esteve por diversas vezes em Santos, durante os mandatos de presidente e senador. Em uma dessas visitas, em 1962, foi homenageado com o diploma de Cidadão Santista, pela Câmara Municipal de Santos, e com o título de Irmão Benemérito, pela Santa Casa de Santos. ${ }^{233}$

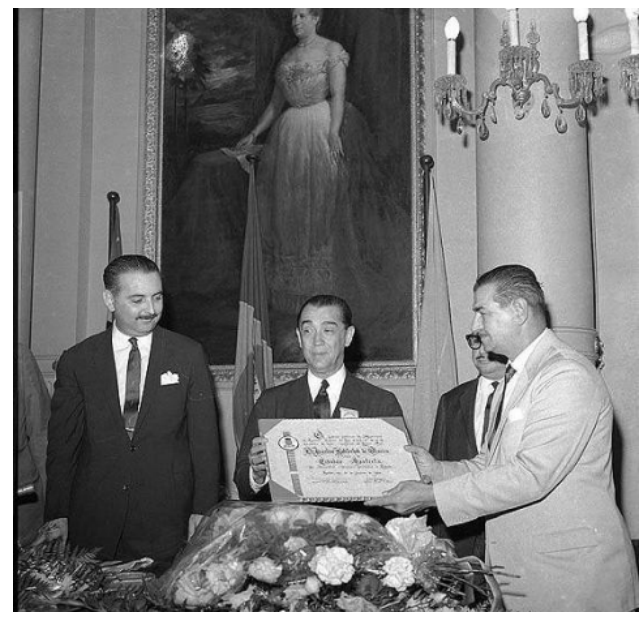

Juscelino Kubitschek durante visita a Santos, quando foi homenageado com o diploma de Cidadão Santista. Sala Princesa Isabel, Câmara Municipal. Santos. 06 de agosto de 1962. Gelatina/prata, $6 \times 9 \mathrm{~cm}$. Acervo FAMS.

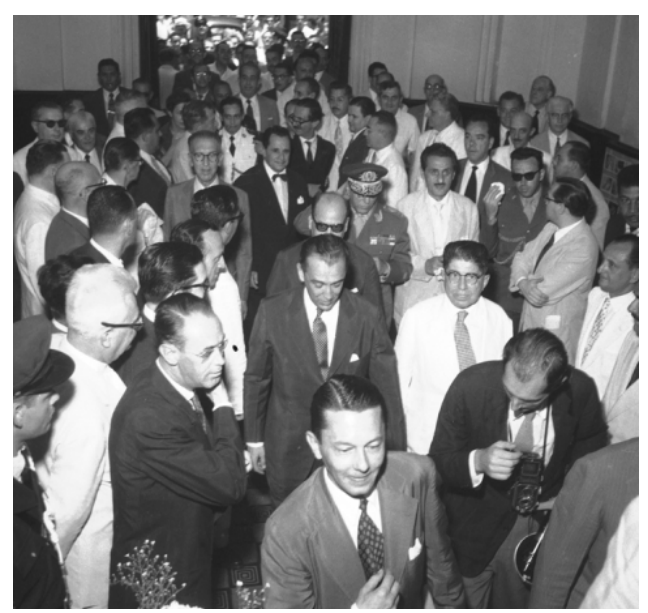

Juscelino Kubitschek chegando à Santa Casa de Santos, onde recebeu o pergaminho de Irmão Benemérito. Santos. 06 de agosto de 1962.

Gelatina/prata, $120 \mathrm{~mm}, 6 \times 9 \mathrm{~cm}$. Acervo FAMS.

${ }^{233}$ Irmão Benemérito. A Tribuna, Santos, 07 de agosto de 1962, p.09. 


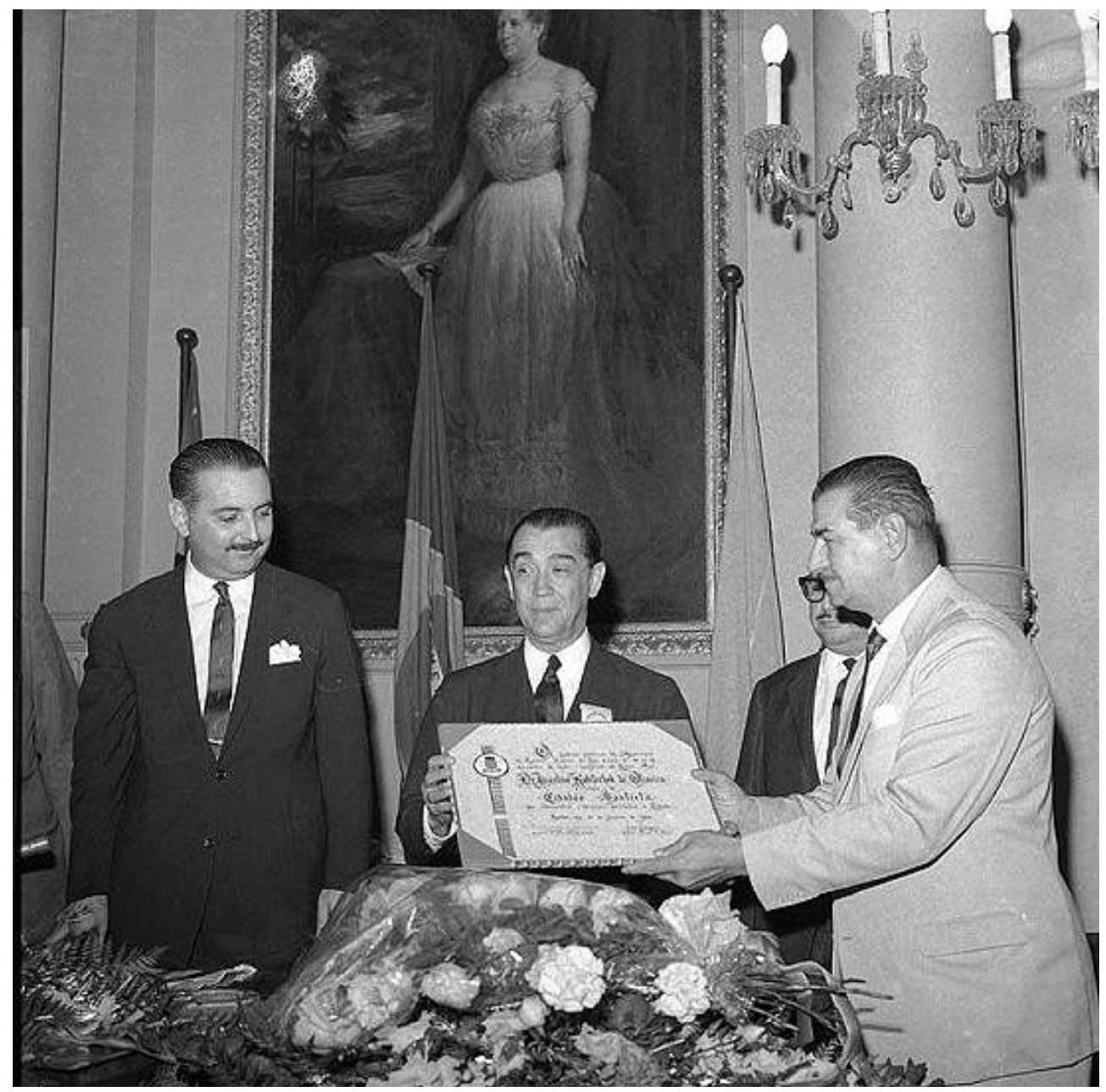

O ex-presidente e então senador de Goiás, Juscelino Kubitschek de Oliveira, sendo homenageado pela Câmara Municipal com o diploma de Cidadão Santista, em 06 de agosto de 1962.

A imagem nos mostra, à esquerda, Fernando Oliva, então presidente da Câmara Municipal de Santos, e, à direita, o vereador Antonio Di Carlis, propositor do título, entregando o diploma a Juscelino Kubitschek. A solenidade aconteceu na Sala Princesa Isabel, no Paço Municipal, em 06 de agosto de $1962 .{ }^{234}$ O quadro da Princesa Isabel, ao fundo, é um óleo sobre tela do pintor milanês Ângelo Cantú, intitulado "A Redentora". A foto registra partes das arandelas instaladas no recinto ${ }^{235}$. Ao todo, a sala possui 16 arandelas. Todas as peças (quadro e arandelas) permanecem no espaço.

\footnotetext{
${ }_{234}^{234}$ JK Cidadão Santista. A Tribuna. Santos, 07 de agosto de 1962, p.14.

${ }^{235}$ As arandelas de bronze e cristal foram importadas da Bohemia, província da antiga Tchecoslováquia, atual República Tcheca, em 1938.
} 
José Herrera lembra bem daquele dia:

JK era muito querido e simpático. O povo gostava dele porque era receptivo. Nesse dia, acompanhei-o durante todo o tempo e ele não perdeu o bom humor... Na verdade, essa também foi uma visita política, porque ele tinha intenção de voltar à Presidência. ${ }^{236}$

O fotógrafo se recorda também de outras várias passagens do ex-presidente pela Cidade, e lembra, especialmente, de quando veio inaugurar os armazéns 30 e 31 da Companhia Docas de Santos, em 1957:

O Juscelino esteve várias vezes aqui em Santos. Era o melhor presidente para se fotografar. Eu podia tirar foto à vontade, ele nunca se opunha... Quando ele esteve visitando o Porto, para inaugurar alguns armazéns, eu ia ao lado dele explicando o que eram as coisas no caminho, o que era o Moinho Santista, explicando os armazéns, o que era exportado... Enfim, tudo. Porque as pessoas que o acompanhavam não sabiam de nada. Se não fosse eu, ele tava perdido. ${ }^{237}$

\footnotetext{
${ }^{236}$ Depoimento do fotógrafo. 26/10/2005.
}

${ }^{237}$ Depoimento do fotógrafo. 26/10/2005. 


\subsection{2 - GETÚLIO VARGAS}

Getúlio Vargas esteve várias vezes em Santos. Segundo o escritor Nelson Salasar Marques, autor da obra Imagens de um Mundo Submerso, a primeira visita do expresidente à Cidade, já na qualidade de ditador, aconteceu "em 1937 ou 1938". ${ }^{238}$ Além desta vez, Santos recebeu o ditador em julho de 1945, para as inaugurações do Aquário Municipal e do atual prédio da Santa Casa de Misericórdia. ${ }^{239}$ José Herrera conta também que lembra de Getúlio Vargas estar em Santos em muitas outras ocasiões, principalmente em inaugurações no Porto.
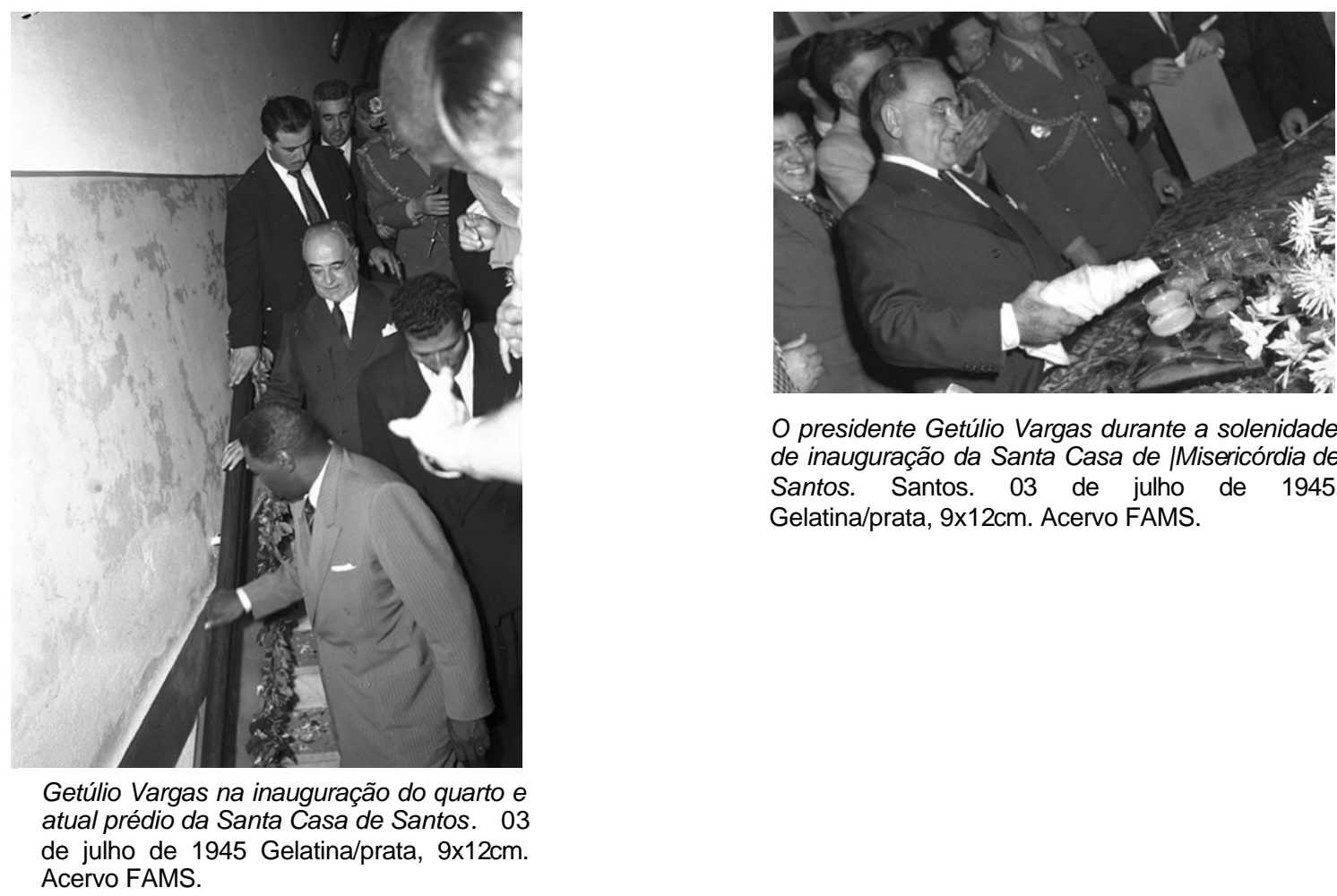

O presidente Getúlio Vargas durante a solenidade de inauguração da Santa Casa de /Misericórdia de Santos. Santos. 03 de julho de 1945. Gelatina/prata, $9 \times 12 \mathrm{~cm}$. Acervo FAMS.

\footnotetext{
${ }^{238}$ MARQUES, Nelson Salasar, Imagens de um Mundo Submerso, passim.

${ }^{239}$ Acontecimento exponencial na vida de Santos, Santos, A Tribuna, 03 de julho de 1945, p.5 e 6.
} 


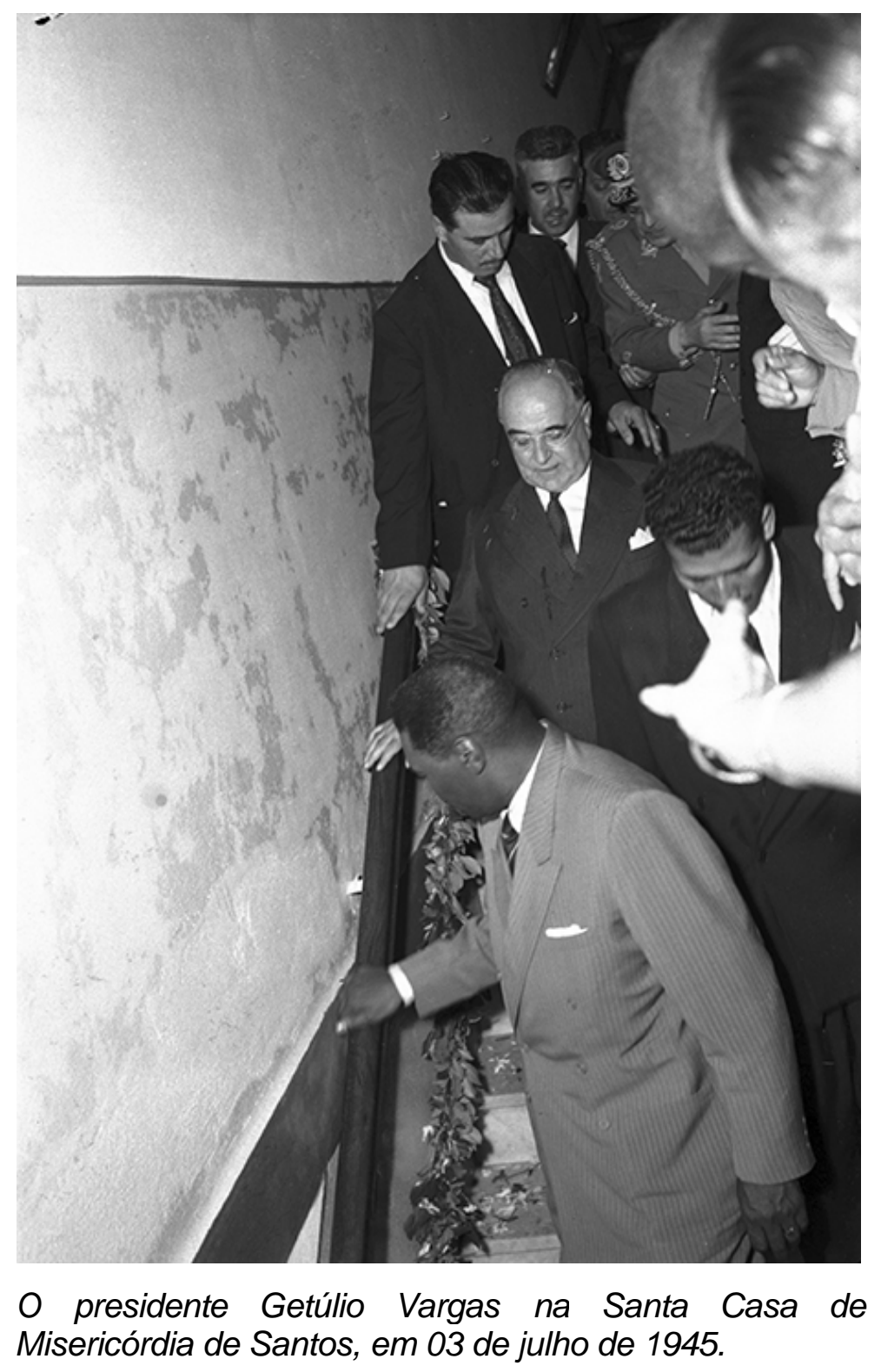

A imagem mostra o então presidente Getúlio Vargas, de óculos e cabeça baixa, conhecendo as dependências da Santa Casa de Misericórdia de Santos, em 03 de julho de 1945. A visita aconteceu por ocasião da inauguração do hospital. Vemos também, a sua frente, Gregório Fortunato, o guarda-costas do presidente, sobre quem até um livro já foi escrito: O Anjo da Fidelidade, de José Louzeiro. José Herrera lembra muito bem da ocasião e da dificuldade de fotografar o ex-presidente: 
Para mim, é uma das fotos mais interessantes porque mostra o famoso guarda-costas negro de Getúlio [...] Sempre foi muito complicado fotografar o Getúlio e esta imagem eu só consegui porque estava escondido atrás de uma cortina... Ele veio descendo as escadas, chegando mais perto e aí eu bati [...] Mas, normalmente, os seus guarda-costas não deixavam ninguém chegar perto, empurravam mesmo. Muitas vezes eles me carregavam no ar para fora dos lugares, eu insistia e voltava. Às vezes, eu gritava para ele (Getúlio Vargas) olhar para câmera e ele fingia que não escutava [...] Muitas fotos dele eu tirei à força [...] Mas nunca tive problemas maiores, sempre consegui fazer o meu trabalho. ${ }^{240}$

${ }^{240}$ Depoimento do fotógrafo. 05/03/2007. 


\subsection{3 - JÂNIO QUADROS}

O ex-presidente Jânio Quadros esteve em Santos diversas vezes, entre elas durante a sua campanha presidencial e logo após a renúncia, quando embarcou do Porto de

Santos para a Europa. Quando retornou ao Brasil, morou durante algum tempo no

\section{Guarujá.}

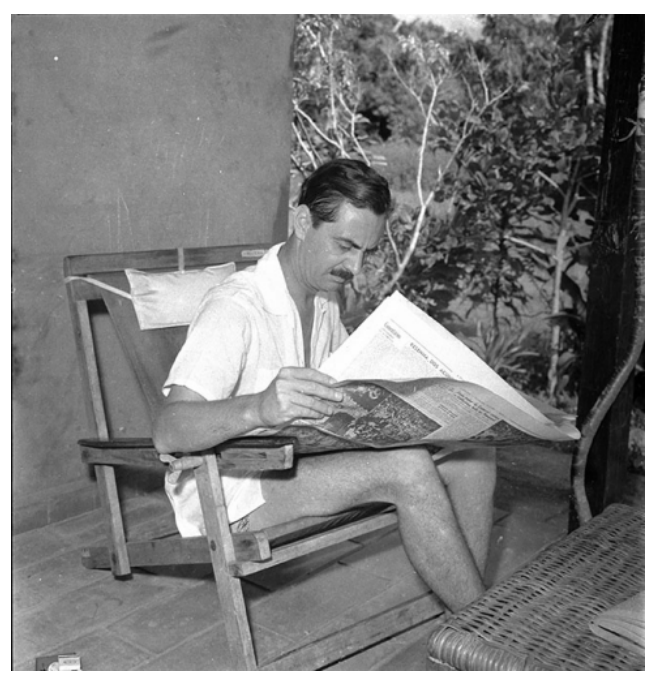

Jânio Quadros lendo o jornal A Tribuna em sua casa de praia. Praia de Pernambuco, Guarujá. Início da década de 1950. Gelatina/prata, 6x6cm. Acervo FAMS.

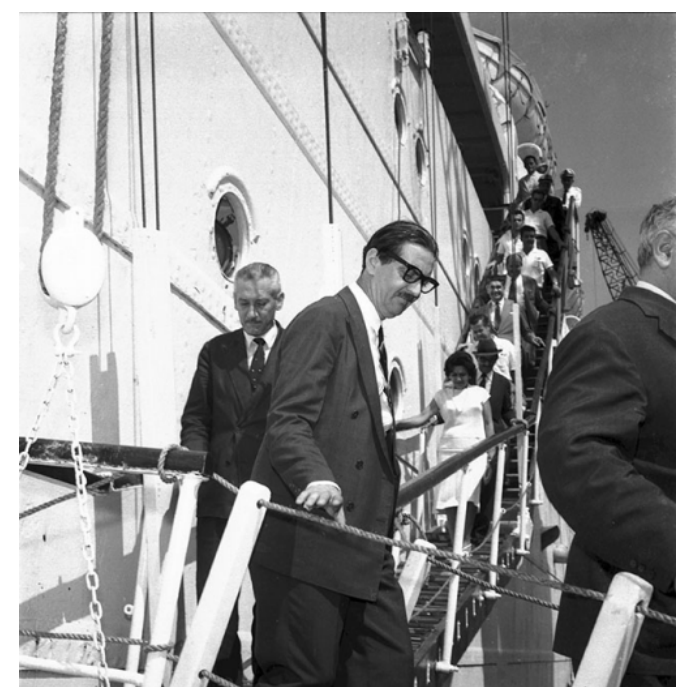

Jânio Quadros desembarcando no Porto de Santos após viagem a vários países. Santos. 1959. Gelatina/prata, $9 \times 12 \mathrm{~cm}$. Acervo FAMS.

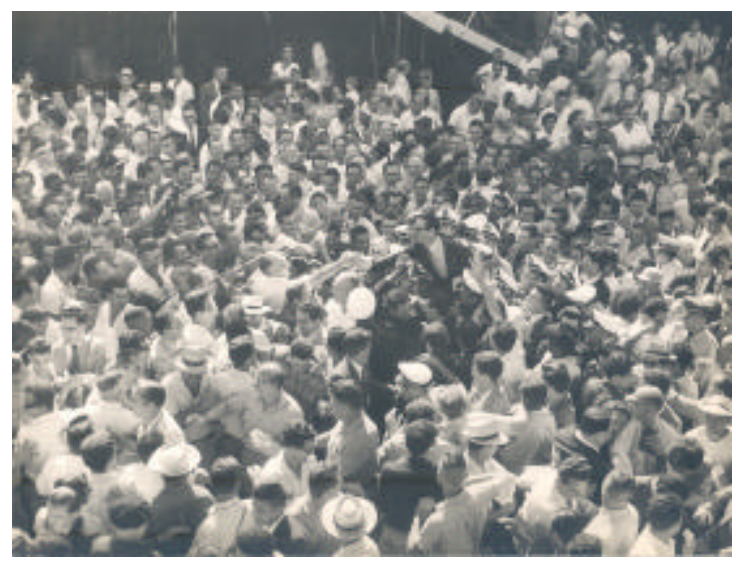

Jânio Quadros sendo carregado pela multidão no Porto de Santos, após desembarcar do transatlântico Arlanza e discursar no Armazém 16 e anunciar a sua candidatura à Presidência da República do Brasil. Santos. Novembro de 1959. Gelatina/prata, 9x12cm. Acervo FAMS. 


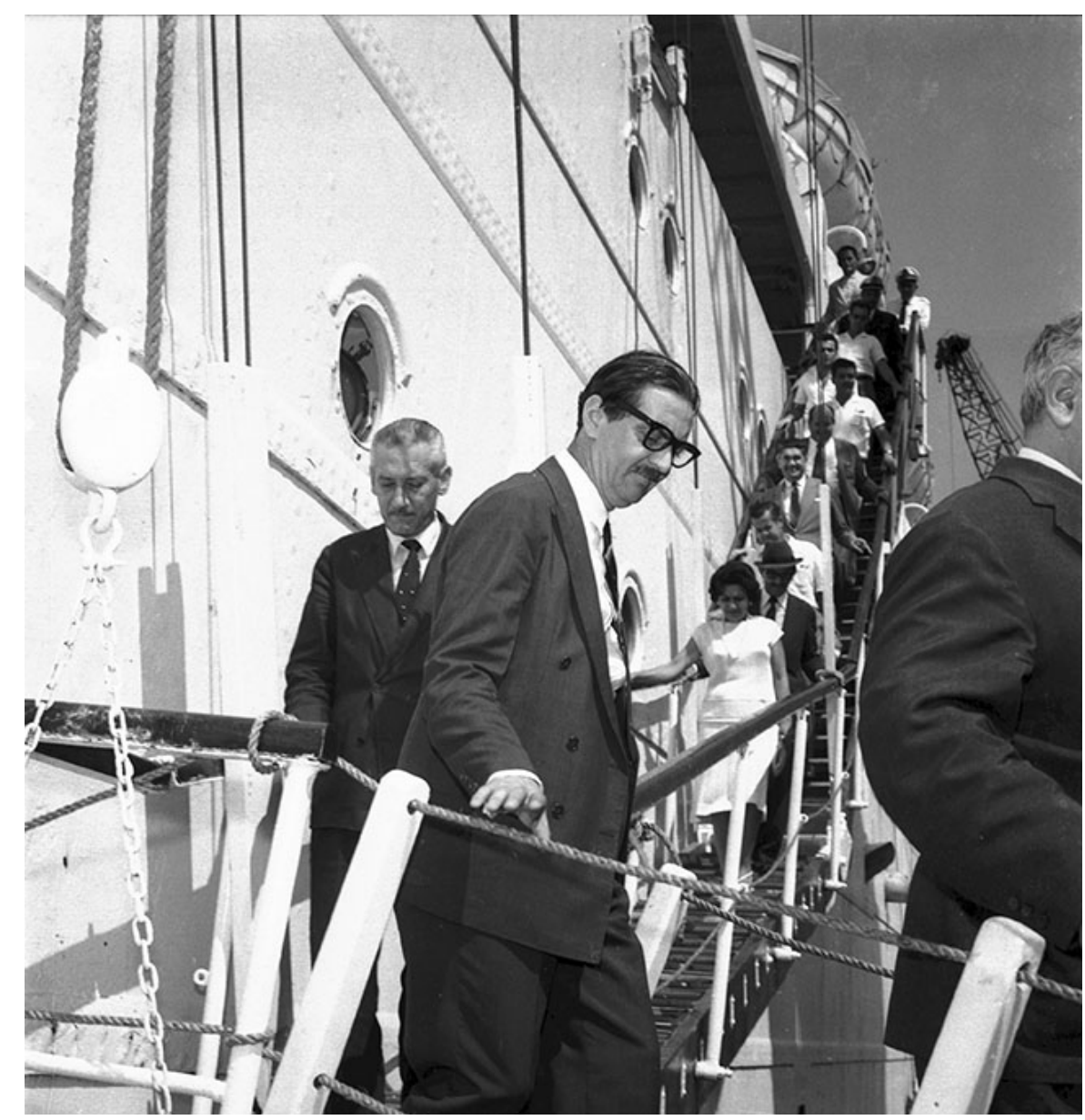

Jânio Quadros desembarcando no Porto de Santos, em novembro de 1959.

Na imagem, o ex-prefeito paulistano, ex-governador paulista e então deputado federal, Jânio Quadros, aparece desembarcando do navio Arlanza no Porto santista, em 28 de novembro de 1959, após uma viagem que realizou com sua esposa Eloá, a mãe Leonor e a filha Dirce Maria ao redor do mundo, oportunidade em que visitou a Rússia, a China, a Índia, o Egito, a lugoslávia e a Inglaterra. Retornou ao Brasil já como candidato à Presidência da República pela União Democrática Nacional $\left(\right.$ UDN). ${ }^{241}$

José Herrera afirma que Jânio foi um dos políticos que mais fotografou e que mais soube 'mexer' com o povo:

${ }^{241}$ Jornal A Tribuna. 29 de novembro de 1959. 
Ele adorava aparecer, se exibia mesmo. Seus comícios eram barulhentos e seus discursos inflamados, e o povo adorava. Não há como negar que ele era inteligentíssimo, mas também meio maluco e cheio de manias. No apogeu de sua vida política era uma tortura para a Imprensa. Era notícia diária, mas só Deus sabe o trabalho que dava. Quando vinha para sua casa no Guarujá era um tormento para a gente. Ficávamos aguardando horas e horas. ${ }^{242}$

Como informa o jornal $A$ Tribuna, Jânio Quadros, auto-intitulado o homem do "tostão contra o milhão" desde os tempos da prefeitura paulistana, deu início a sua campanha eleitoral para a presidência da República assim que desembarcou em no porto santista. Percorreu as ruas da Cidade ao som do jingle Varre, Varre, Vassourinha, distribuindo as famosas vassourinhas que eram o símbolo de sua campanha contra a corrupção nacional.

Jânio Quadros foi eleito em 03 de outubro de 1960, aos 43 anos de idade e 13 anos de política, com 48\% dos votos apurados, exatos 5 milhões 636 mil 632 votos. Permaneceu como presidente pelo breve período de sete meses, de 31 de janeiro a 25 de agosto de 1961, quando renunciou. ${ }^{243}$ Após a renúncia, dirigiu-se ao Guarujá, hospedando-se na residência do industrial José Kalil, onde fez o seu primeiro pronunciamento após o acontecido, manifestando a vontade de viajar para o exterior com família. ${ }^{244} \mathrm{O}$ ex-presidente embarcou no navio Uruguay Star, em dia 28 de agosto de 1961, rumo ao seu exílio para Londres. O povo esperou em vão no cais do armazém 15, pois, assim que embarcou, recolheurse à cabine, não mais aparecendo no convés. ${ }^{245}$

\footnotetext{
${ }^{242}$ Depoimento do fotógrafo. 05/03/2007.

${ }^{243}$ Jânio Quadros morre em SP aos 75 anos. A Tribuna. Santos. 17 de fevereiro de 1992, p. A7, A8 e A9.

${ }^{244}$ Todo o mundo comenta a renúncia do presidente Jânio Quadros. A Tribuna, Santos. 27 de agosto de 1961, p.01.

${ }^{245}$ Lágrimas sentidas. A Tribuna, Santos. 29 de agosto de 1961, p.01.
} 


\subsection{4 - MÁRIO COVAS}

Nascido em Santos, em 21 de abril de 1930, Mário Covas Júnior sempre foi considerado um político sério e destacou-se como um dos mais importantes homens públicos do Brasil. Gostava dos pastéis do Bar do Carioca e do Santos Futebol Clube, do qual era sócio remido desde 1963. Ao final da faculdade, confessou a alguns amigos que seus sonhos eram ser prefeito de Santos e presidente do Santos Futebol Clube.

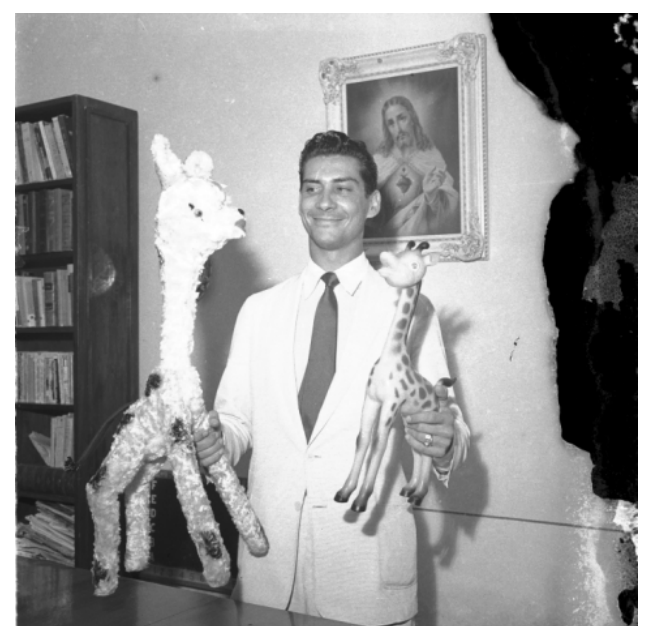

O ex-governador de São Paulo e então candidato à Prefeitura de Santos, Mário Covas, em seu comitê. Santos. 1961. Gelatina/prata, $6 \times 6 \mathrm{~cm}$. Acervo FAMS.

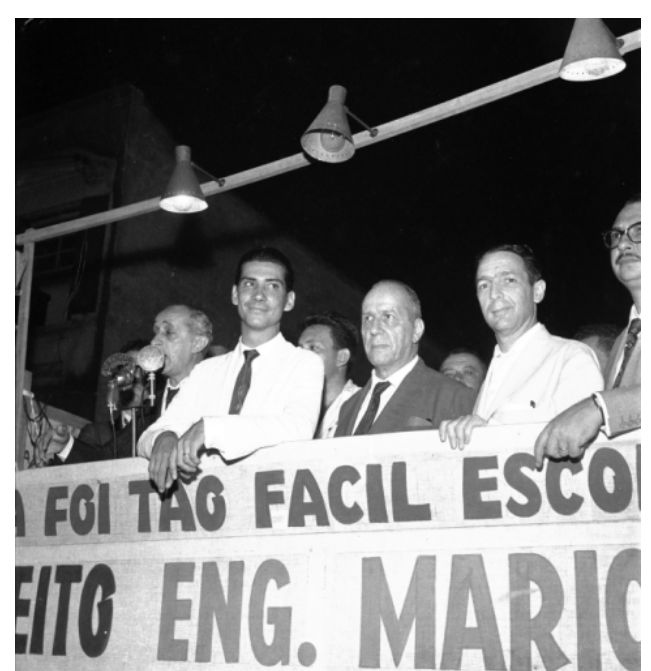

O então candidato a prefeito de Santos, Mário Covas, de camisa branca e gravata escura, durante um comício, ao lado de aliados. Santos. 1961. Gelatina/prata, $6 \times 6 \mathrm{~cm}$. Acervo FAMS. 


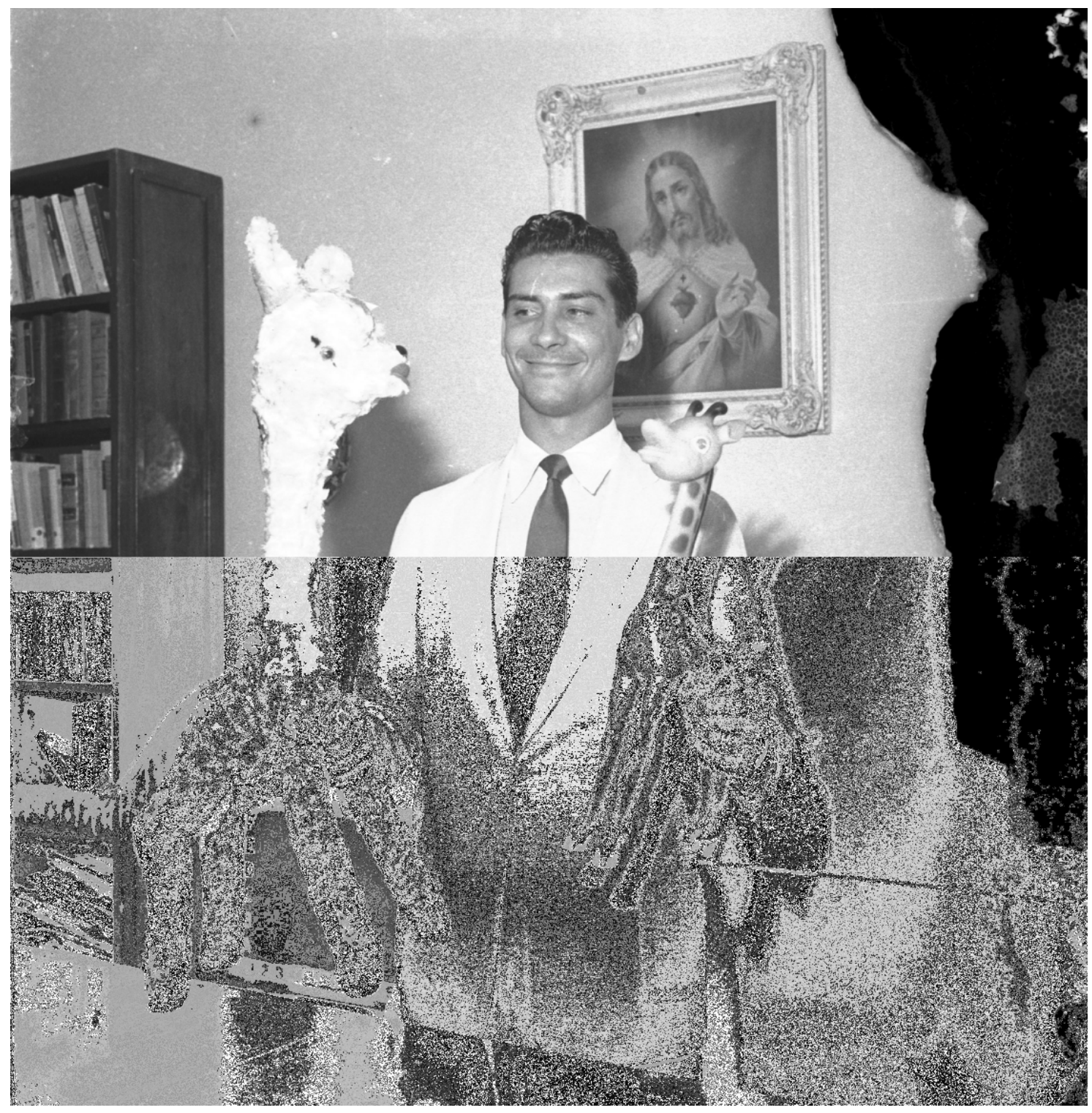

O então candidato à Prefeitura de Santos, Mário Covas, posando para a foto em seu comitê eleitoral, em 1961.

$\mathrm{Na}$ imagem podemos ver que o ex-governador paulista e então candidato à Prefeitura de Santos, Mário Covas, está posando para foto em tom de brincadeira segurando duas girafas, uma em cada mão. A girafa foi adotada como mascote e símbolo da campanha por causa do pescoço comprido de Covas. Percebemos ainda que um quadro com a gravura de Jesus Cristo enfeita a sala do comitê do candidato, atrás da mesa. À esquerda, uma estante com livros. Constatamos também a má conservação do negativo, evidente em toda a lateral direita da imagem. 
Conforme registrou o jornal $A$ Tribuna, as eleições de 1961 aconteceram em 26 de março e Mário Covas não conquistou a prefeitura de Santos. Com 22.369 votos, ficou em segundo lugar, atrás do eng. ${ }^{\circ}$ Luiz La Scala Jr, que foi eleito prefeito com 28.286 votos. ${ }^{246}$ Quanto às eleições naquela época, José Herrera cita o fato do povo ter que votar para prefeito e para vice-prefeito também:

Hoje a gente vota no prefeito e elege automaticamente o seu vice, mas antes não era assim. Os candidatos a prefeito e a viceprefeito faziam a campanha juntos, mas um poderia ser eleito e 0 outro não ${ }^{247}$.

Quanto ao seu envolvimento com a política, Herrera é enfático:

Eu não podia fazer política de jeito nenhum! Eu lidava com todo mundo e não poderia arranjar inimizades, precisava estar sempre bem com todos. Por isso, eu sempre fui isento e nunca quis saber de partido, graças a Deus! ?8 $^{28}$

Em 1962, Mário Covas foi eleito deputado federal pelo PST e reeleito, em 1966, pelo MDB. Teve a carreira política interrompida pela cassação e seus direitos políticos suspensos pelo Ato Institucional n. 5 em 1968, retornando à vida pública dez anos depois, em 1979, como presidente regional do MDB.

Candidatou-se pela terceira vez à Câmara Federal no ano de 1982, sendo o terceiro mais votado no Estado. No mesmo ano recebeu o título de Cidadão Santista. Em 1983, foi nomeado prefeito de São Paulo pelo governador Franco Montoro, permanecendo no cargo até 31 de dezembro de 1985.

Com a maior votação da história política do país, 7,7 milhões de votos, elegeur se senador em 1986. Ao lado de nomes como Fernando Henrique Cardoso, Franco

\footnotetext{
${ }^{246}$ Eleito prefeito municipal de Santos o eng ${ }^{\circ}$ Luiz La Scala Júnior. A Tribuna, Santos. 28 de março de 1961, p.01.

247 Depoimento do fotógrafo, $15 / 08 / 2006$.

248 Depoimento do fotógrafo, 15/08/2006.
} 
Montoro e José Serra, fundou o Partido da Social Democracia Brasileira (PSDB), em 1988. No ano de 1989, foi derrotado nas eleições para a Presidência da República.

Totalizando 8 milhões e 661 mil votos, Covas chegou ao Governo do Estado de São Paulo em 1994, reelegendo-se em 1998, com 9 milhões e 800 mil votos. No dia 22 de janeiro de 2001, anunciou o afastamento de suas funções por conta de um câncer. Geraldo Alckimin assumiu interinamente o governo paulista. Em 06 de março do mesmo ano, Mário Covas faleceu vítima de falência múltipla dos órgãos. ${ }^{249}$ 


\subsection{5 - ESMERALDO TARQUÍNIO}

Esmeraldo Tarquínio nasceu em São Vicente em 12 de abril de 1927. Eleito prefeito de Santos em novembro de 1968, com cerca de 45 mil votos, não chegou a tomar posse e teve seus direitos políticos cassados a 10 de março de 1969. O vice-prefeito eleito Oswaldo Justo, chocado com a situação, decidiu não assumir a Prefeitura e renunciou em 28 de março, poucos dias antes de ser empossado. ${ }^{250}$

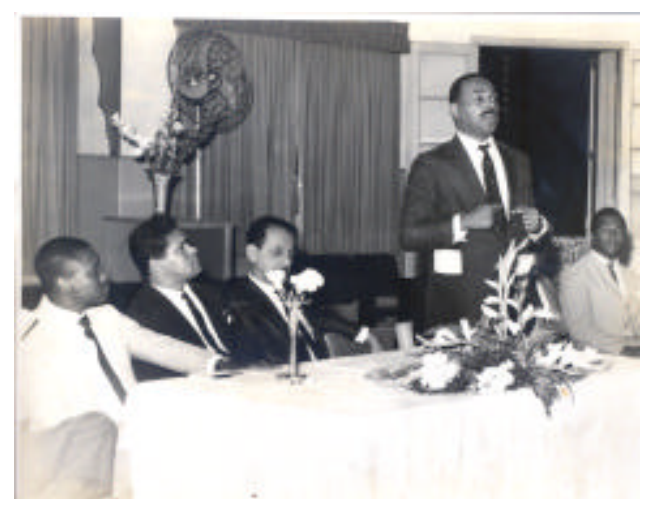

O então candidato a prefeito de Santos, Esmeraldo Tarquínio, discursando durante reunião no Santos Futebol Clube. Santos. 1968. Gelatina/prata, $9 \times 12 \mathrm{~cm}$. Acervo José Dias Herrera.

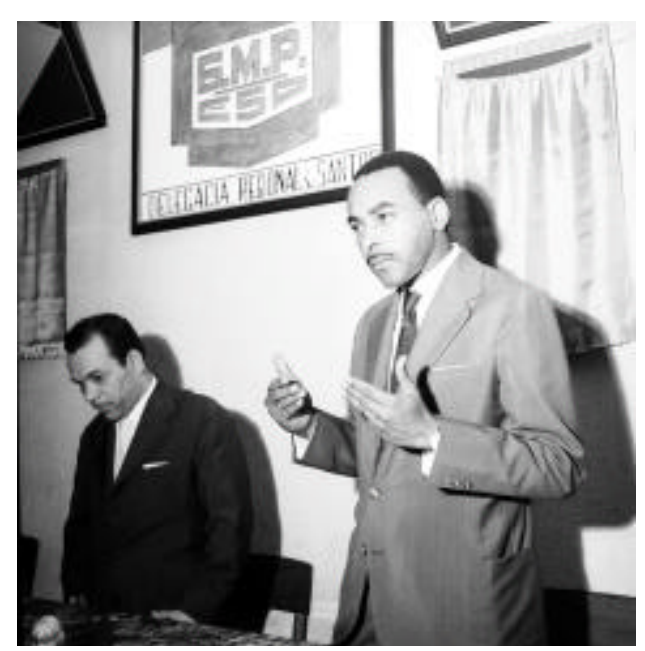

Esmeraldo Tarquínio na Delegacia Regional de Santos $-5^{\circ}$ distrito. Santos. 1968. Gelatina/prata, $9 \times 12 \mathrm{~cm}$. Acervo José Dias Herrera.

${ }^{250}$ Justo renuncia: vem intervenção. A Tribuna, Santos. 29 de março de 1969, p.01. 


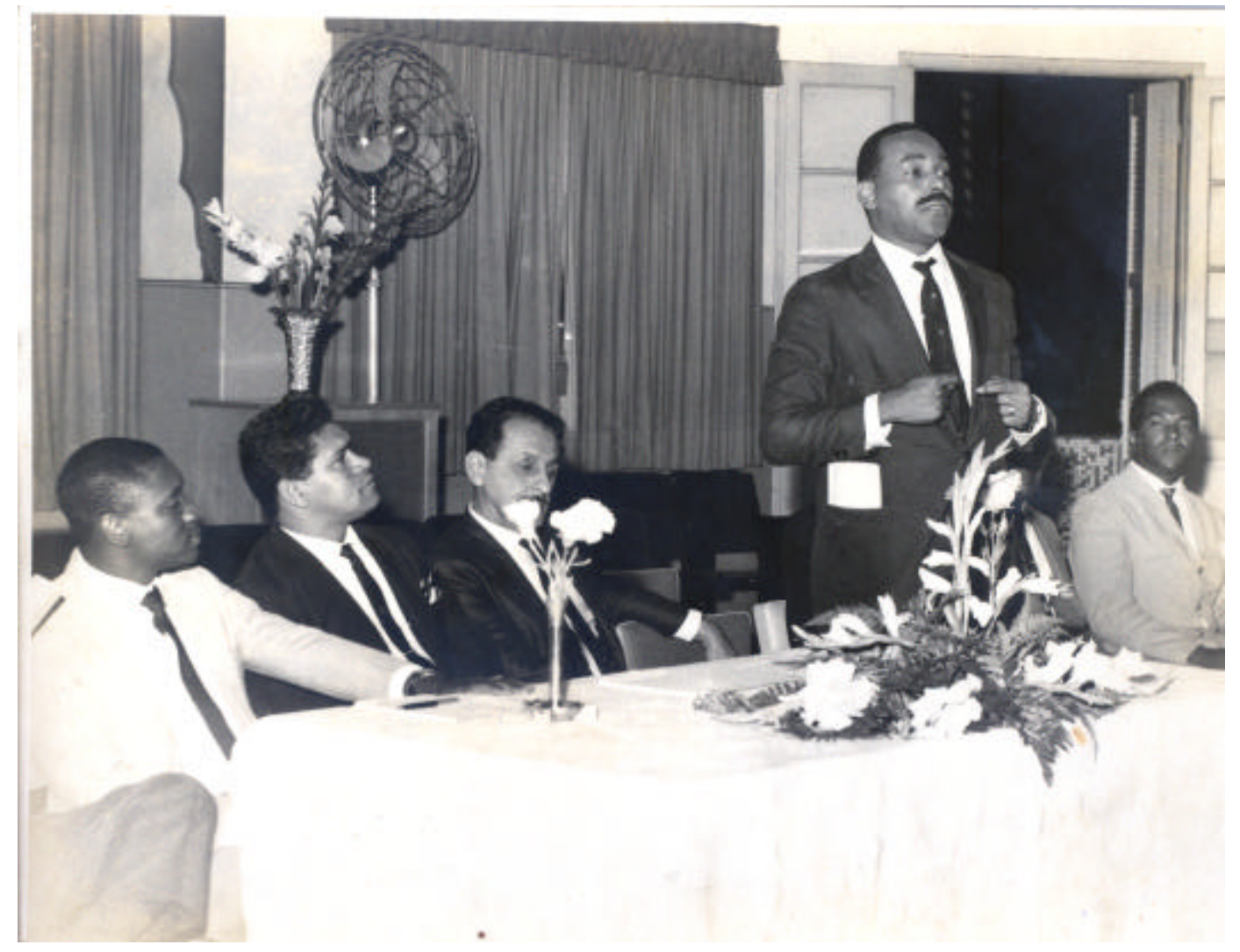

O advogado e então deputado estadual Esmeraldo Soares Tarquínio de Campos Filho, candidato à Prefeitura de Santos, discursando no Santos Futebol Clube, no ano de 1968.

Como podemos ver na foto, à mesa, junto a Esmeraldo Tarquínio, estão membros do partido MDB, com destaque para o então deputado Athiè Jorge Coury, à esquerda do candidato. As reuniões, estudos e planos eram comuns durante a campanha de Esmeraldo Tarquínio, que afirmava estar elaborando um novo esquema administrativo para a cidade de Santos. Após o encontro, que aconteceu na sede do Santos Futebol Clube, um jantar foi oferecido a Tarquínio pelo próprio Clube.

Esmeraldo Tarquínio foi eleito prefeito de Santos e, para José Herrera, o fato de ele ser negro foi indiferente para a sua vitória.

Ele era muito popular e tinha um histórico político muito bom, era competente e nunca teve seu nome envolvido em escândalos... Tinha boas idéias e isso fez com que ele vencesse as eleições... 
Todo mundo gostava dele; ele quase não conseguia andar pela rua porque era parado pelo povo a todo instante... E ele dava atenção a todos. ${ }^{251}$

A cassação de Tarquínio gerou muita confusão e revolta, conforme recordou José Herrera. Para o fotógrafo, a renúncia de Osvaldo Justo foi a melhor atitude naquela ocasião.

A população ficou revoltada e desiludida. Eu achei a cassação uma bobagem, totalmente desnecessária. O Esmeraldo Tarquínio não era nenhuma ameaça... Quanto ao Justo, ele era muito democrático; não aceitava essas imposições e injustiças. Por isso, renunciou... Na verdade, ninguém concordava com a cassação de Tarquínio. Aquilo tudo era um grande absurdo ${ }^{252}$

Bastante querido, Esmeraldo Tarquínio recebeu inúmeras homenagens em vida e depois de falecido. O Salão Nobre da Prefeitura de Santos, por exemplo, tem o seu nome e, como homenagem póstuma, a Câmara da Cidade concedeu a Tarquínio o título de Cidadão Santista. ${ }^{253}$

\footnotetext{
251 Depoimento do fotógrafo. 29/11/2006.

252 Depoimento do fotógrafo. 29/11/2006

253 A homenagem de Santos a Esmeraldo Tarquínio. Jornal da Orla, Santos. 14 e 15 de abril de 2007, p.02.
} 


\subsection{6 - OSVALDO JUSTO}

Osvaldo Justo foi prefeito entre 1984 e 1988, o primeiro após a recuperação da autonomia santista. Em 1968, após a cassação do prefeito eleito Esmeraldo Tarquínio, Justo, que era seu vice, não concordou em assumir o cargo, embora não houvesse restrições a seu nome por parte do Governo Militar. Após deixar a Prefeitura, Justo foi deputado estadual por dois mandatos consecutivos, o último deles encerrado em 1998. O político faleceu dia 14 de abril de 2003.

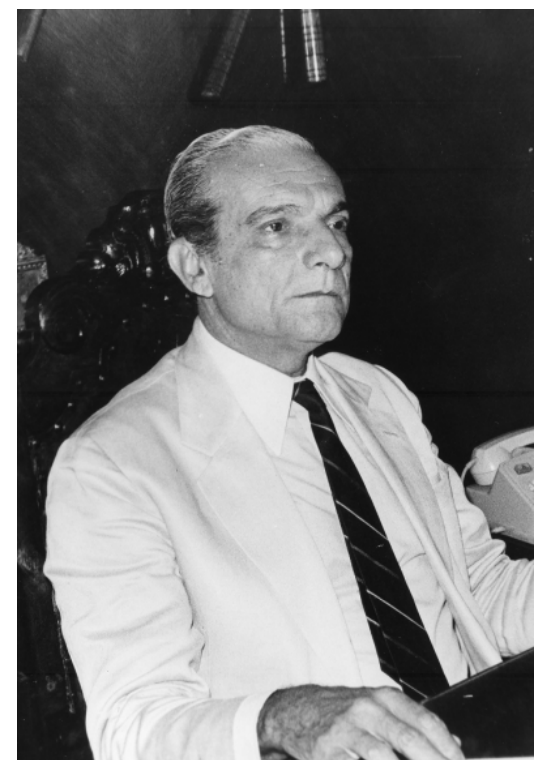

Osvaldo Justo, prefeito de Santos entre setembro de 1984 e dezembro de 1988.

Santos. 1986. Gelatina/prata, $35 \mathrm{~mm}$ $10 \times 15 \mathrm{~cm}$. Acervo José Dias Herrera.

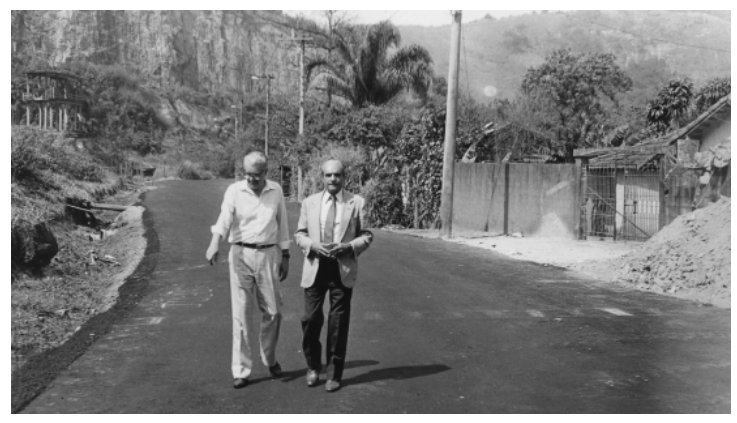

O então prefeito de Santos, Osvaldo Justo, vistoriando a pavimentação do caminho São Jorge, na Zona Noroeste. Santos. 30 de agosto de 1988. Gelatina/prata, 35mm, $10 \times 15 \mathrm{~cm}$ Acervo José Dias Herrera.

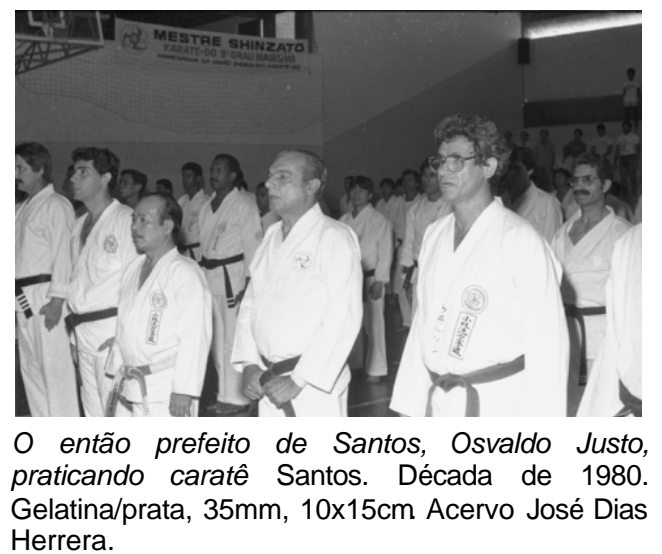

Herrera. 


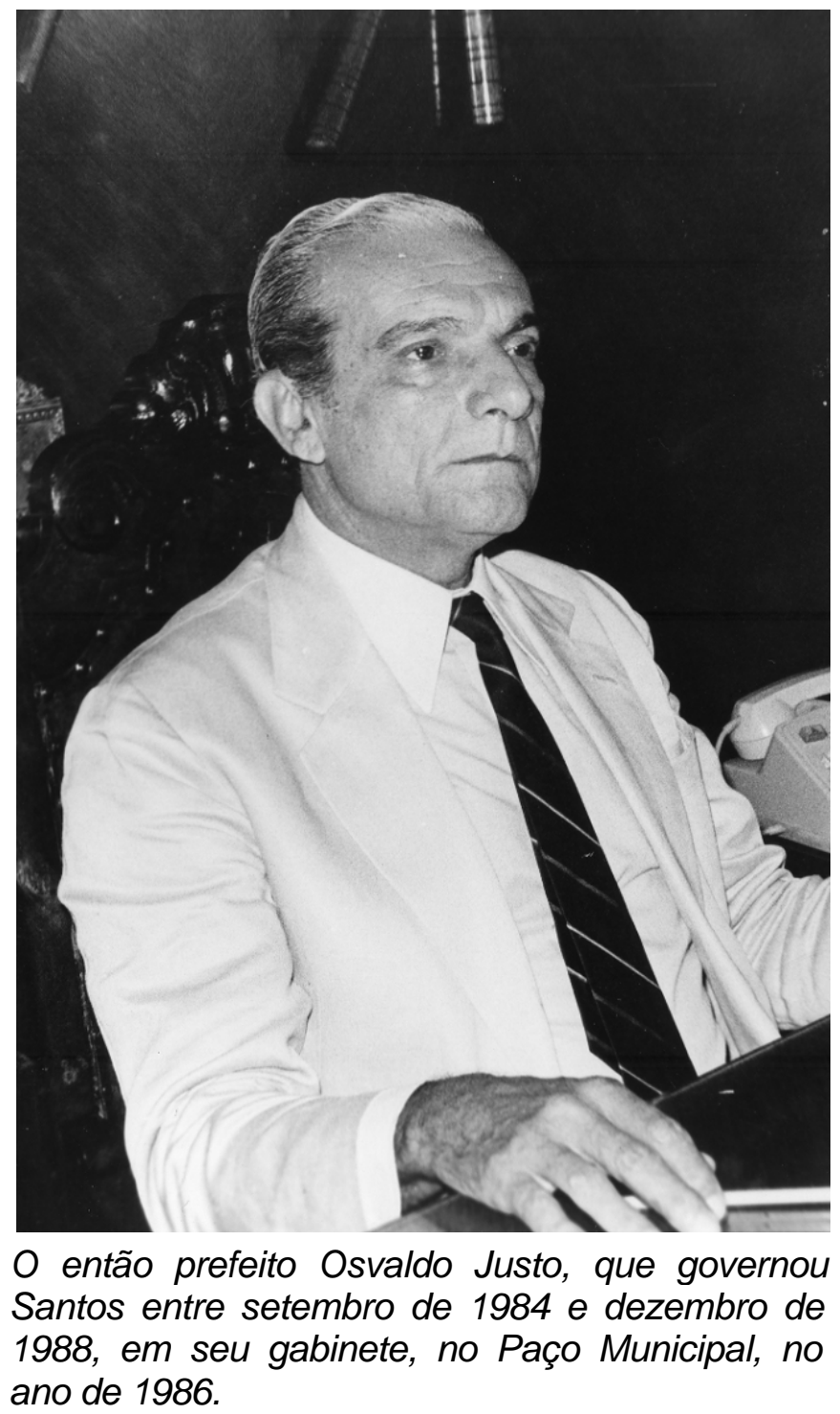

Após 15 anos de prefeitos nomeados, Santos viveu um momento histórico e consagrou a sua autonomia política com a posse de Osvaldo Justo, eleito prefeito da Cidade nas eleições diretas de 03 de junho de $1984 .^{254}$ José Herrera lembra da expectativa do dia das eleições:

Estava todo mundo muito eufórico e com muita vontade de votar. Além do povo estar sem votar há um tempão, as últimas eleições não tinham dado sorte para os vencedores: o La Scala morreu e o Tarquínio foi cassado. Deus me livre! As pessoas estavam até meio desconfiadas, mas deu tudo certo. Acho que a vitória do Justo foi uma resposta ao que tinha acontecido ao

${ }^{254}$ Posse de Justo restaura autonomia. A Tribuna. Santos. 10 de julho de 1984, p.01. 
Esmeraldo Tarquínio. Dessa vez, o Justo foi candidato a prefeito e o Tarquínio Neto entrou na chapa como vice. ${ }^{255}$

O jornal $A$ Tribuna da época cita a coincidência lembrada por Herrera:

A história repetiu-se. Um Justo e um Tarquínio são novamente os eleitos pelo povo de Santos, com votação consagradora [...] Em meio à emoção, o prefeito eleito também declarou: Não quiseram Esmeraldo Tarquínio prefeito; agora terão que aceitar o seu filho como vice-prefeito. ${ }^{256}$

A restauração do estado de direito foi definitivamente conquistada no dia 02 de agosto de 1983, quando a caravana da autonomia ocupou o Congresso Nacional para pressionar os parlamentares pela aprovação do projeto, posteriormente sancionado pelo vice-presidente Aureliano Chaves, no exercício da Presidência. ${ }^{257}$

Sobre a pessoa de Osvaldo Justo, o fotógrafo tem muito o que contar:

Eu gostava muito dele; era muito amigo, era uma pessoa simples. Ele era macrobiótico e, às vezes, me convidava para almoçar... Eu não gostava no começo, mas acabei ficando freguês. Também era adepto à cultura japonesa: praticava caratê - era faixa preta - e valorizava o respeito às pessoas... A grande vantagem dele era a sua honestidade e seriedade, tanto que morreu pobre. ${ }^{258}$

Sobre o político Osvaldo Justo, as histórias também são inúmeras:

Uns consideravam ele um visionário, outros, um louco. O grande sonho dele era construir um túnel ligando o Centro à Zona Noroeste e uma ponte atravessando o canal do Estuário. Ele também tinha algumas manias, como agendar reuniões às 5 horas da manhã no Paço Municipal. Dizem que ele fazia a reunião e depois trancava a sua sala para dormir [...] Ele não tinha horário, acordava de madrugada e circulava pela Cidade para averiguar as ruas, os problemas, visitar os hospitais de surpresa. Ele, sempre

\footnotetext{
255 Depoimento do fotógrafo, em 29/11/2006.

256 Santos reconquista a liberdade. A Tribuna, Santos. 04 de junho de 1984, p.05.

257 Santos nas urnas. A Tribuna, Santos. 03 de junho de 1984, p.01.

258 Depoimento do fotógrafo, em 29/11/2006.
} 
que podia, fiscalizava as ações e serviços do seu governo pessoalmente e sem prévio aviso. ${ }^{259}$

Falando sobre as eleições em geral, o fotógrafo lembra que costumavam acontecer normalmente no dia 15 de novembro, mas o resultado só era conhecido dias depois.

Hoje é urna eletrônica, uma facilidade imensa. A gente sabe no dia quem venceu as eleições. Antigamente, os votos eram assinalados naquele papel, colocados nas urnas, e tinham que ser contados um a um. As pessoas ficavam dias contando os votos e podiam se atrapalhar. Hoje, dizem que a urna eletrônica é muito mais confiável, não tem como errar a contagem. Outra diferença é a boca de urna. Antigamente esse negócio era pesado, a Cidade ficava coberta de papel. Hoje, apesar de proibida, também fazem, mas a proporção é bem menor. ${ }^{260}$ 


\subsection{7 - WASHINGTON LUIZ}

Washington Luís Pereira de Souza nasceu na cidade de Batatais, interior paulista, foi prefeito da cidade natal e de São Paulo. Em 1920, foi eleito governador do Estado, quando proferiu sua famosa frase "Governar é abrir estradas". Investiu na modernização da infra-estrutura de transportes, construindo 1.326 quilômetros de novas estradas no Estado de São Paulo. Assumiu a presidência da República em 15 de novembro de 1926. Foi deposto pela Revolução de 1930, em outubro daquele ano. Viveu os 17 anos seguintes exilado na Europa e nos Estados Unidos e, em 1947, voltou ao Brasil. Morreu em São Paulo, em 4 de agosto de 1957.

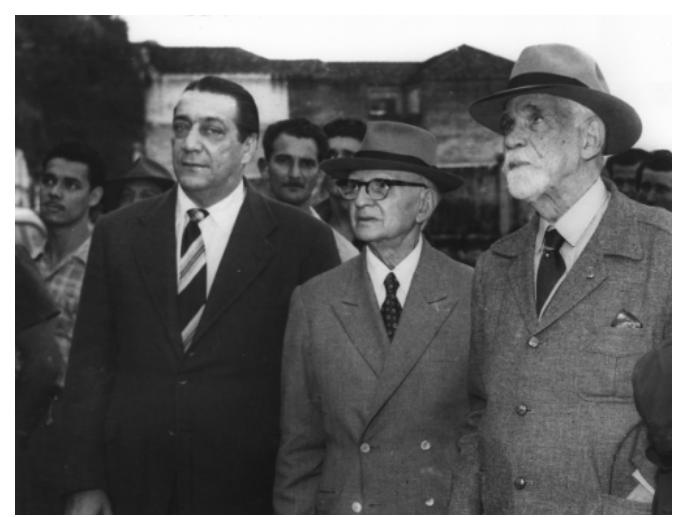

O ex-presidente Washington Luiz sendo recebido por Manuel Nascimento Jr, então diretor do jornal $A$ Tribuna. Santos. Julho de 1953. Gelatina/prata, $6 \times 6 \mathrm{~cm}$. Acervo FAMS.

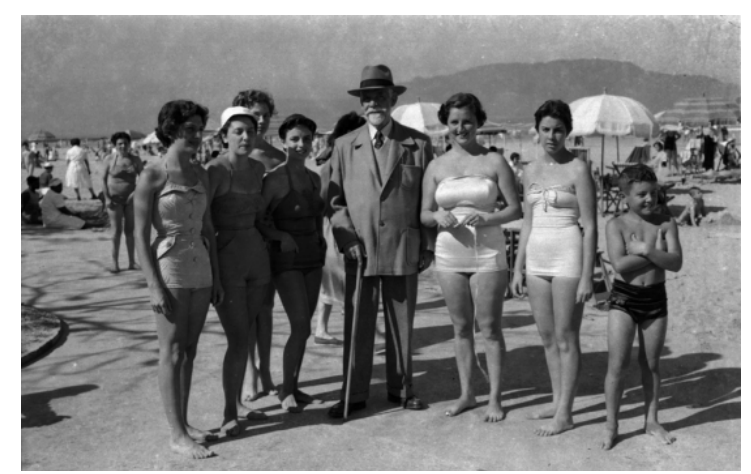

O ex-presidente Washington Luiz na praia do Gonzaga, fotografando ao lado de banhistas em frente ao antigo Hotel Parque Balneário. Santos. Julho de 1953. Gelatina/prata, $6 \times 6 \mathrm{~cm}$. Acervo FAMS. 


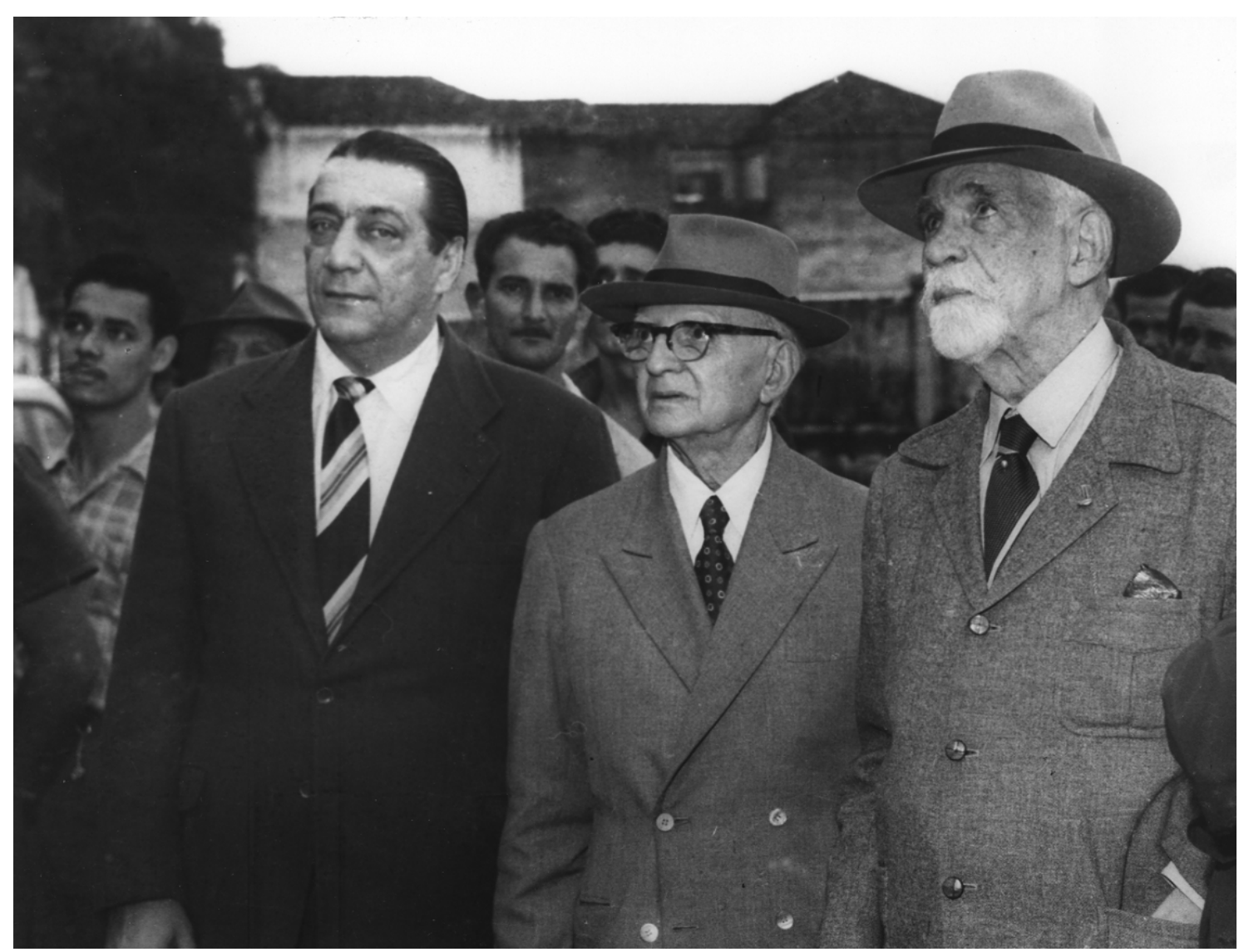

O ex-presidente Washington Luiz sendo recebido por Manuel Nascimento Jr., então diretor do jornal A Tribuna, em Santos, em julho de 1953.

A imagem nos mostra Washington Luiz à direita, de terno, chapéu e barba branca. O homem ao centro, de terno, chapéu e óculos, é Manuel Nascimento Jr., então diretor do grupo A Tribuna, que recebeu o ex-presidente durante a sua estadia em Santos, em julho de 1953.

Conforme noticiou o jornal A Tribuna, de 09 de julho de 1953, o ex-presidente chegou a Santos no dia 01 e declarou que permaneceria na Cidade até o fim do mês para repousar e rever lugares pitorescos e amigos. Hospedourse no Parque Balneário Hotel. ${ }^{261}$

${ }^{261}$ Jornal A Tribuna, Em Santos o Dr. Washington Luiz. Santos. 09 de julho de 1953, p.07. 


\subsection{8 - CHARLES DE GAULLE}

Dezenas de indústrias dos mais diversos tipos compõem o pólo industrial de Cubatão. Mas foi a Companhia Siderúrgica Paulista (Cosipa) que ajudou a marcar a importância da Cidade para a região, para o Estado de São Paulo e para o Brasil. Fundada em 1953, iniciou suas operações industriais em 18 de dezembro de 1963, com a inauguração da Laminação a Quente pelo presidente da República, João Goulart. Em 15 de outubro de 1964, a Laminação a Frio foi inaugurada pelo presidente francês Charles De Gaulle. ${ }^{262}$

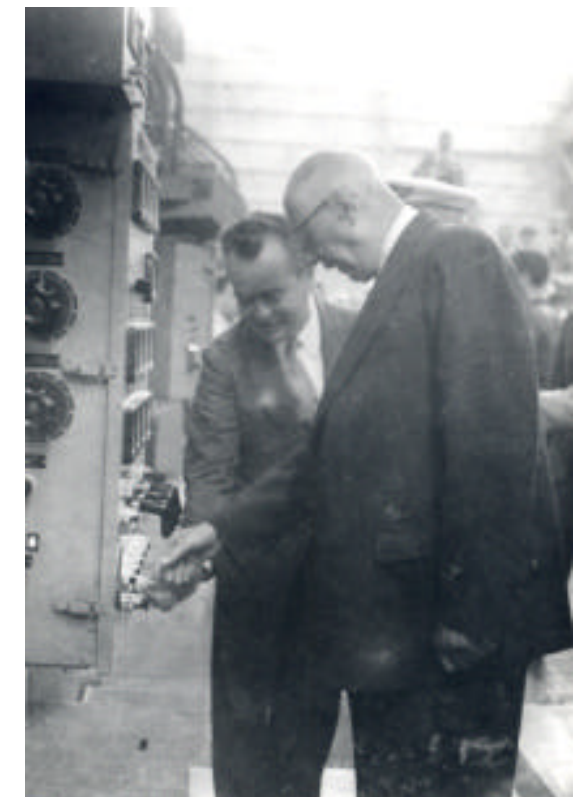

De Gaulle no momento em que acionava a nova unidade, ao lado de Luiz Dumont Vilares, presidente da Cosipa. 15 de outubro de 1964, Gelatina /prata, $24 \times 36 \mathrm{~cm}$. Acervo FAMS.

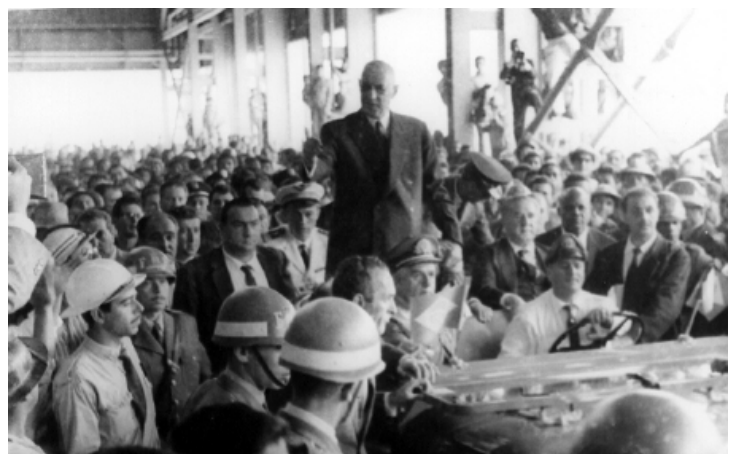

O presidente da França, general Charles De Gaulle, por ocasião da inauguração da Laminação de Tiras a Frio na Cosipa. Cubatão. 15 de outubro de 1964, Gelatina/prata, $24 \times 36 \mathrm{~cm}$. Acervo FAMS. 


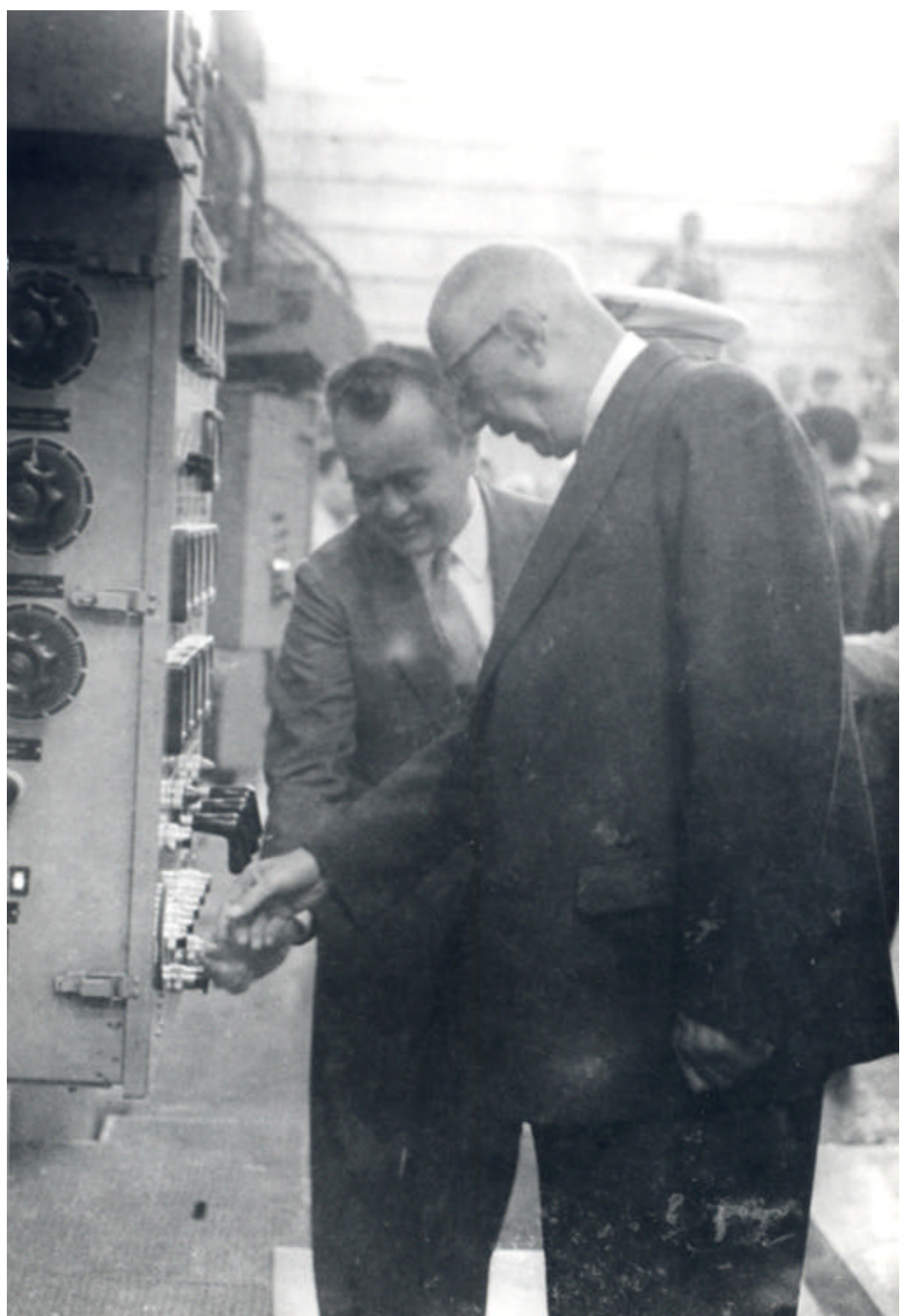

O general Charles De Gaulle no momento em que acionava o botão da máquina de Laminação a Frio no Cosipa, em 15 de outubro de 1964.

Em 15 de outubro de 1964, o presidente da França, general Charles De Gaulle, líder da resistência francesa durante a Segunda Guerra Mundial, esteve na Usina Siderúrgica José Bonifácio, em Cubatão, para inaugurar a Laminação de Tiras a Frio, construída com tecnologia francesa pela Companhia Siderúrgica Paulista Cosipa. A foto registra "o momento" em que De Gaulle acionava o botão da nova unidade ao lado do presidente da Cosipa, Luiz Dumont Vilares. O novo equipamento 
era um laminador de três cadeiras, quádruo e continuo, com controle automático de espessura e emprego de raios x. Sua capacidade de produção é da ordem de 350 mil toneladas por ano.

No dia da solenidade, segundo José Herrera, a arquibancada reservada para a imprensa - onde ele e outros jornalistas estavam - ficava a uma distância de 100 metros do equipamento (laminador de tiras a frio) que De Gaulle ia acionar.

Daí, eu saí correndo... os guardas vieram atrás de mim, mas eu consegui atravessar... Quando eu cheguei bem perto, ele já tinha apertado o botão. Eu fiz um sinal com a cabeça indicando para que ele apertasse o botão novamente e falei 'S'il Vous Plaît, S'il Vous Plaît'. E ele apertou de novo para que eu fotografasse. ${ }^{263}$

Conforme publicou o jornal $A$ Tribuna, com o novo laminador, a siderúrgica passou a produzir um tipo de chapa indispensável à indústria automobilística, livrando o Brasil de pesados ônus de importação. O veículo informou ainda que o equipamento importado da França valia cerca de 33 milhões de dólares. ${ }^{264}$

\footnotetext{
${ }^{263}$ Depoimento do fotógrafo, em 23/09/2005.

${ }^{264}$ A Tribuna. Santos. 16 de outubro de 1964, p.3.
} 


\subsection{9 - GREVES}

Desde o final do século XIX e início do XX, e entre os anos de 1940 e 1964, Santos teve como uma de suas características marcantes a organização de movimentos sociais, destacando-se as atividades dos partidos políticos e dos sindicatos. Com o desenvolvimento da Cidade e do Porto, várias categorias profissionais foram se organizando com o propósito de lutar por seus direitos, salários e pela diminuição da jornada de trabalho, resultando em greves cada vez mais constantes, principalmente a partir de 1930. Com o Golpe de 1964, a fase das manifestações grevistas teve fim. ${ }^{265}$ A primeira greve depois de 1964 - a dos trabalhadores portuários - aconteceu em março de 1980, ainda em meio ao governo da ditadura militar. ${ }^{266}$

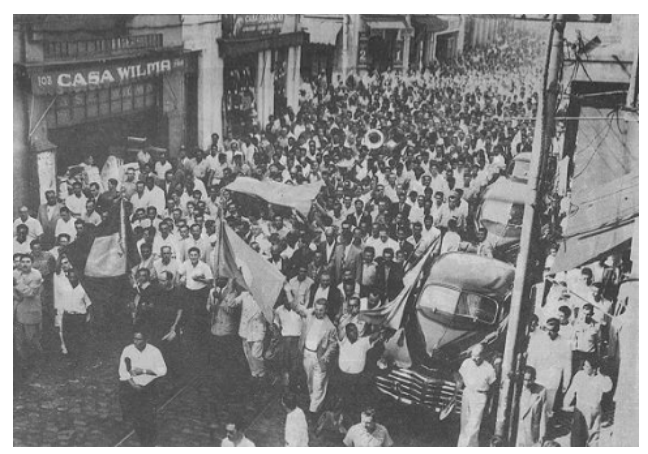

Passeata dos operários portuários na Rua General Câmara. Santos, 1959. Gelatina/prata, 24×36cm Acervo FAMS.

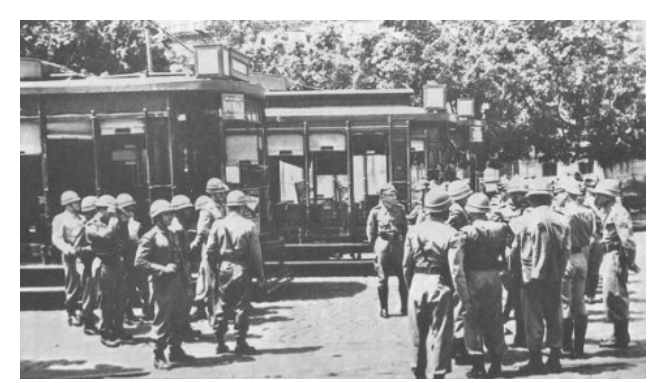

Forças policiais ocupam a garagem dos bondes da Vila Mathias durante a greve dos transportes coletivos. Santos. Setembro de 1962. Gelatina/prata, $24 \times 36 \mathrm{~cm}$ Acervo FAMS.

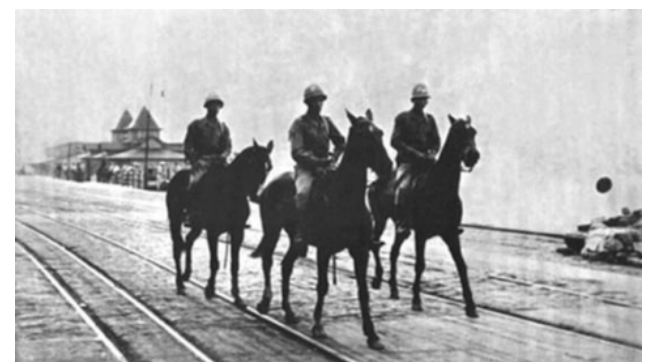

Cavalaria da Força Pública vigiando o cais do Porto, próximo ao atracadouro do ferry-boat para Guarujá, durante as greves. Santos, 1963. Gelatina/prata, $24 \times 36 \mathrm{~cm}$ Acervo FAMS.

\footnotetext{
${ }^{265}$ Santos e o Golpe de 64. Diário Oficial de Santos, 16 de abril de 2004, , p.2. Memória Santista.

${ }^{266}$ A primeira greve depois de 1964, A Tribuna, Santos, 18 de março de 1980.
} 


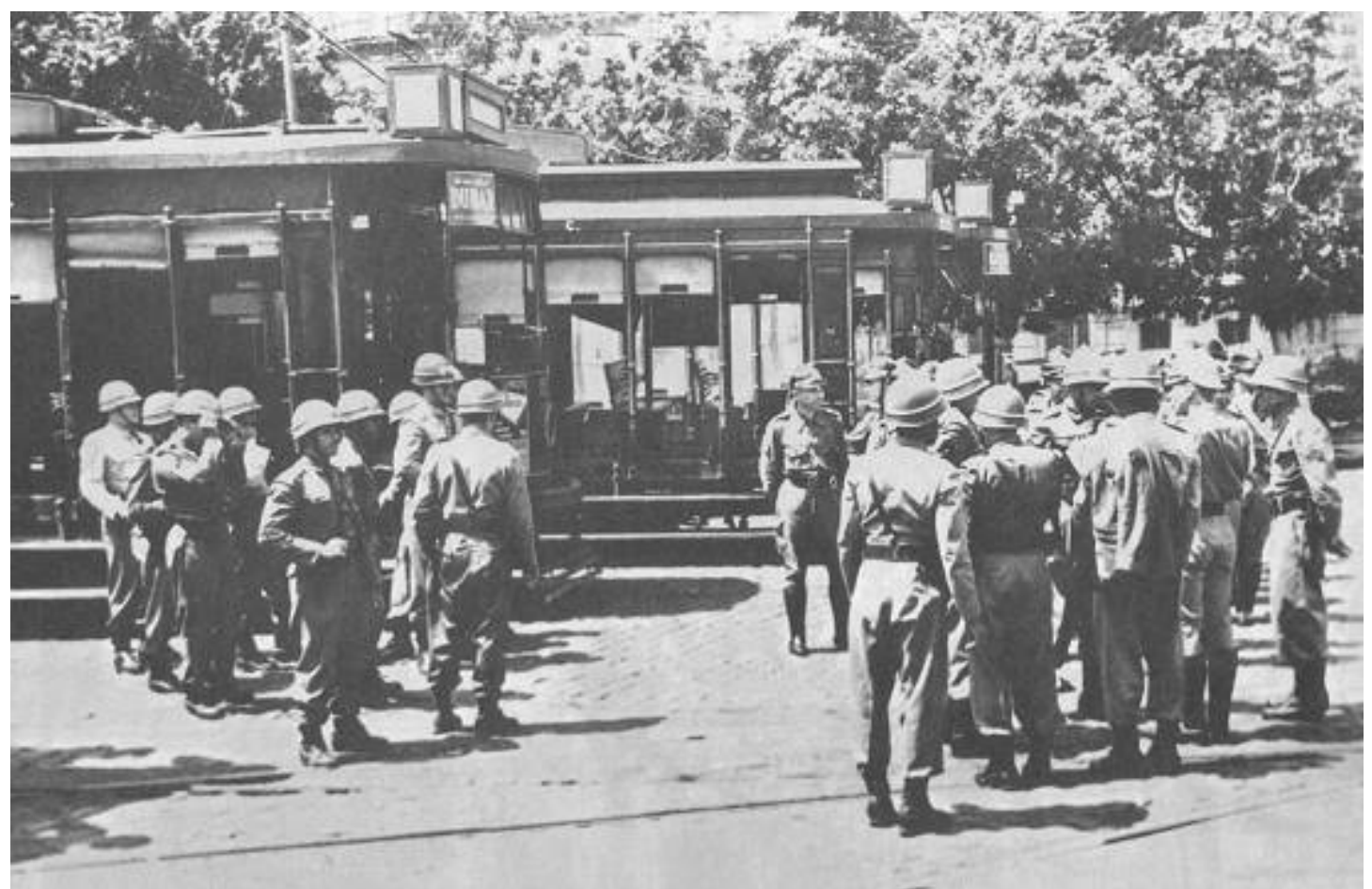

Forças policiais ocupando a garagem dos bondes durante a greve dos transportes coletivos em Santos, em setembro de 1962.

A imagem nos mostra cerca de 20 homens da Polícia Militar ocupando a garagem dos bondes, localizada na Av. Rangel Pestana, na Vila Mathias, durante a greve dos transportes coletivos em Santos, em setembro de 1962. Podemos observar que os policiais usam capacete, uniforme completo com botas tipo coturno e carregam um cacetete preso ao cinto nas costas. A foto mostra também quatro bondes estacionados.

O fotógrafo Herrera recorda que, em Santos, o povo sempre foi muito politizado e sempre lutou por seus direitos trabalhistas.

Todas as classes que você pode imaginar entravam em greve, principalmente os funcionários ligados ao Porto. Claro que trabalhadores de outras profissões também: motoristas, enfermeiros... A reivindicação principal era sempre aumento de salário [...] Às vezes, as tropas federais precisaram intervir, mas só para intimidar mesmo. Hoje, é mais difícil aparecer uma greve. ${ }^{26}$

${ }^{267}$ Depoimento do fotógrafo. 29/11/2006. 
A greve dos transportes coletivos em Santos foi iniciada em 05 de julho do mesmo ano e, naquele dia, o Serviço Municipal de Transportes Coletivos publicava, na primeira página do jornal $A$ Tribuna, um esclarecimento ao povo santista informando que os seus empregados haviam paralizado os serviço sem motivos ou explicações. 


\subsection{Transportes e Serviços}

Serviços públicos de transporte, iluminação, água e gás, durante décadas, foram executados em Santos pela The City of Santos Improvements \& Co. Ltd., mais conhecida como City. Em 1887, a empresa deu início ao abastecimento de água e ao sistema de iluminação a gás; em 1870, já tinha a concessão para o transporte de passageiros e mercadorias (serviços de bondes e linhas férreas); em 1903, firmava contrato para a exploração de luz e energia elétrica em todo o município e, em 1928, inaugurava as três primeiras linhas de ônibus.

A City manteve o serviço de transporte coletivo até 1950, quando entregou todo o seu patrimônio viário ao Serviço Municipal de Transportes Coletivos de Santos (SMTC). Forneceu água a Santos, São Vicente e Cubatão até 1953, abasteceu Santos com gás encanado ${ }^{268}$ até 1965, quando aconteceu a explosão do gasômetro, e teve os serviços de eletricidade transferidos para Light ${ }^{269}$ em 1967, quando encerrou definitivamente as atividades na Baixada Santista. ${ }^{270}$

José Herrera não só testemunhou as transformações dos serviços públicos santistas, como também fotografou os inúmeros modelos de carros importados que circulavam pelas ruas de Santos até a década de 1970, época em que o Brasil ainda não tinha uma indústria automobilística estruturada.

\footnotetext{
${ }^{268}$ Gás de rua

${ }^{269}$ Os serviços de eletricidade passaram da Light para a Eletrobrás (1980) e desta para a Eletropaulo (1981). Em 1998, os serviços foram privatizados e passaram para a Companhia Piratininga de Força e Luz (CPFL), que atua em Santos até hoje.

${ }^{270}$ LICHTI, Fernando Martins, História de Santos - Poliantéia Santista, 1996, p. 32 et seq.
} 


\subsection{1 - CARROS IMPORTADOS}

Em 1953, a América Latina era considerada o maior comprador de carros importados do mundo, destacando-se o Brasil e a Venezuela. Segundo dados da época, os países latino-americanos possuíam, em 1940, cerca de 900 mil veículos e, sete anos depois, mais de 1 milhão e 200 mil. No início de 1953, já eram mais de 2 milhões e 200 mil automóveis - um aumento de $280 \%$ em comparação ao ano de 1940. E tem mais: nesses países, a proporção era de um carro para cada 75 habitantes. Já na África, a proporção era de um carro para cada 361 pessoas e na Ásia era de um veículo para cada 783 habitantes. ${ }^{271}$

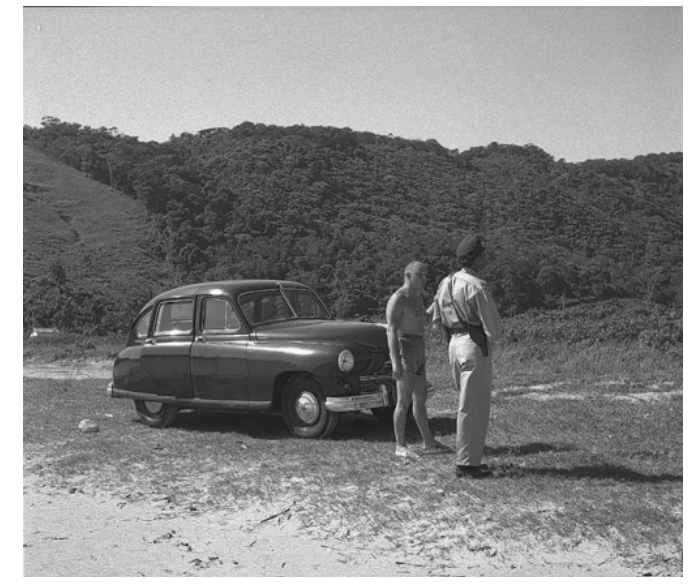

Standard Vanguard 1951, Guarujá. Cécada de 1950. Gelatina/prata, $120 \mathrm{~mm}, 6 \times 6 \mathrm{~cm}$. Acervo particular José Herrera.

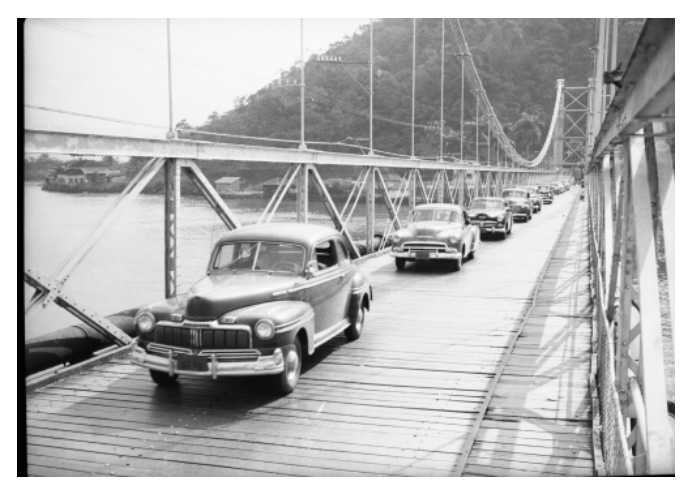

Fileira de carros de passeio atravessando a Ponte Pênsil. O primeiro da fila é um Mercury 1948 e o segundo é um Chevrolet 1951. São Vicente. Meados da década de 1950. Gelatina/prata, $120 \mathrm{~mm}, 6 \times 6 \mathrm{~cm}$. Acervo particular José Herrera.

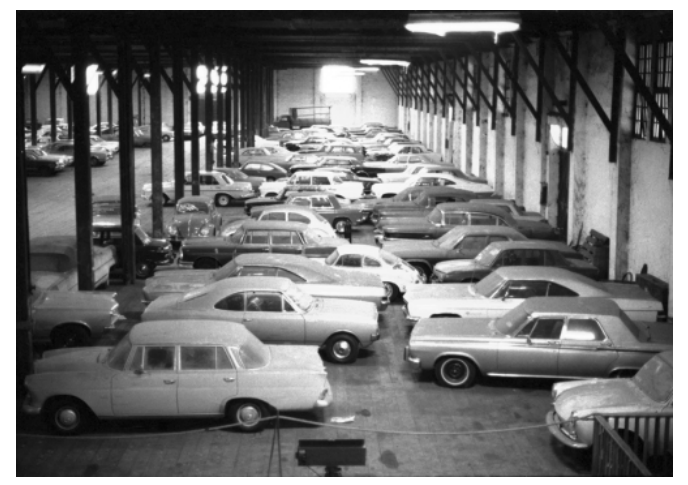

Carros importados retidos em um armazém do Porto. Santos, meados da década de 1960. Gelatina/prata, $120 \mathrm{~mm}, 6 \times 6 \mathrm{~cm}$. Acervo particular José Herrera.

${ }^{271}$ América Latina: o maior mercado automobilístico. A Tribuna. Santos. 25 de julho de 1953, p. 05. 


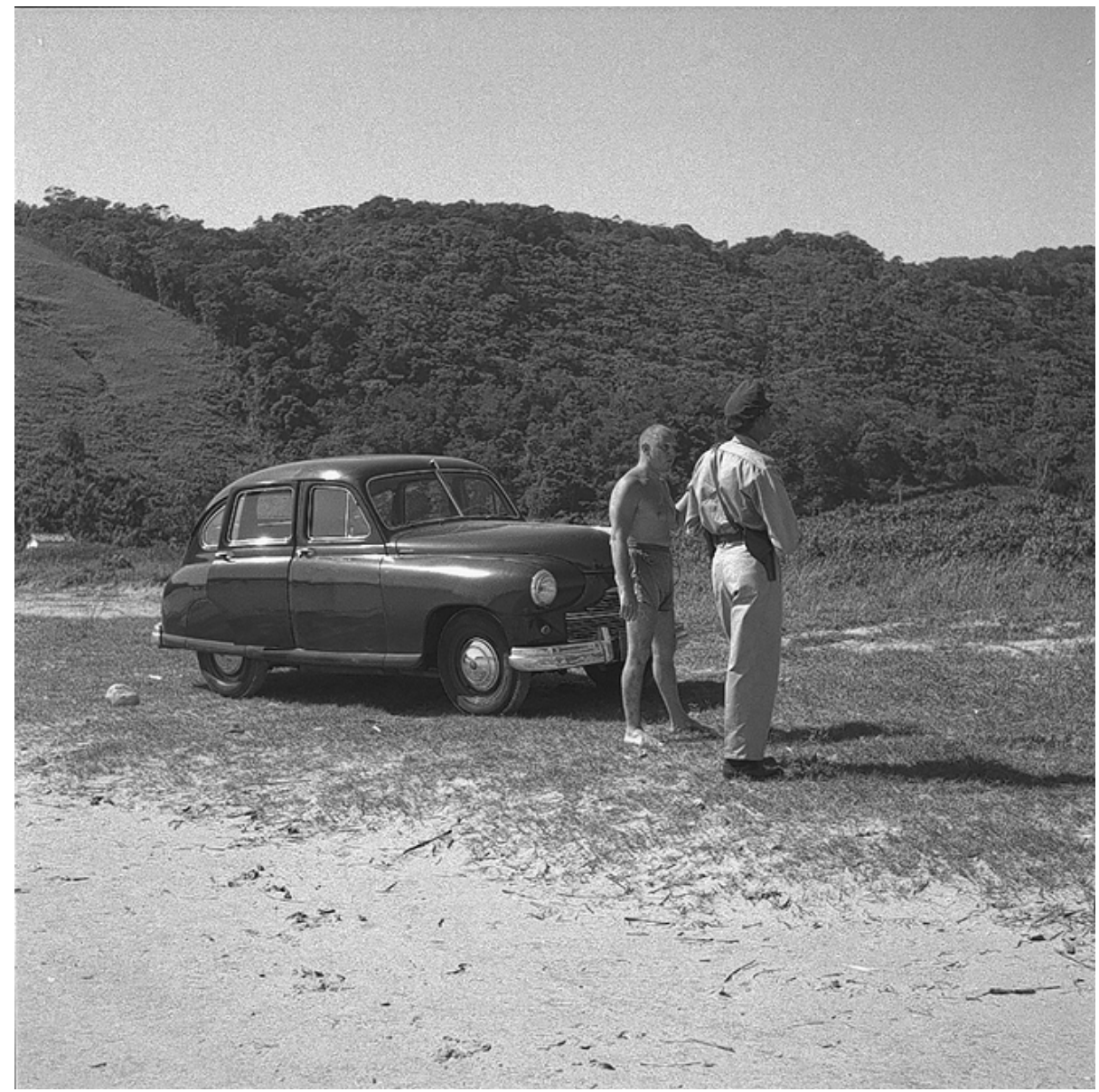

Carro Standard Vanguard 1951, na praia do Guarujá, na década de 1950.

A foto mostra um Standard Vanguard 1951 - carro de passeio inglês -, com saia nas rodas traseiras, estacionado na areia da praia do Guarujá, em meados da década de 1950. Ao fundo, um morro com vegetação nativa. Fora do automóvel, o provável motorista, em traje de banho, conversando com um guarda municipal. Esse modelo de carro era considerado um prenúncio da modernidade, pois já possuía um sistema independente de suspensão.

José Herrera explica que, até a década de 1970, a maioria dos carros que circulava no Brasil era importada:

Os carros chegavam de navio no Porto de Santos e ficavam retidos nos armazéns aguardando a liberação da Alfândega. Eram muito caros, mas as pessoas compravam porque a produção 
brasileira era muito limitada. Praticamente, só tínhamos a Volkswagem, que começou produzindo primeiro o fusca e, mais tarde, a Kombi. ${ }^{272}$

E completa:

Eu mesmo nunca tive um desses carros importados. O meu primeiro carro foi um fusca usado que eu comprei no final da década de 1960. Quando eu comprei, todo mundo já podia comprar e o fusca era o carro do ano. Daí, parece que a Cidade foi invadida, a gente via fusca em todo lugar. Aliás, o meu primeiro carro zero também foi um fusca, sabia? ? $^{273}$

272 Depoimento do fotógrafo. 24/09/2007.

${ }^{273}$ Depoimento do fotógrafo. 24/09/2007. 


\subsection{2 - SERVIÇO DE BONDES}

A primeira linha de bondes elétricos em Santos foi inaugurada a 28 de abril de 1909, sendo o tráfego de bondes de tração animal suprimido em 3 de maio de 1912. Em 1964, começou a paralisação gradual dos bondes e, no dia 28 de fevereiro de 1971, a última linha encerrou as atividades. ${ }^{274}$

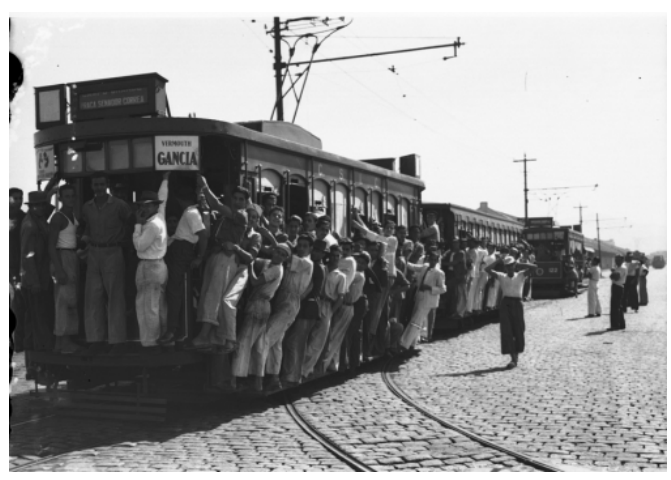

Bonde $19 \mathrm{com}$ reboque. Porto de Santos. Início da década de 1940. Gelatina/prata, $6 \times 9 \mathrm{~cm}$. Acervo FAMS.

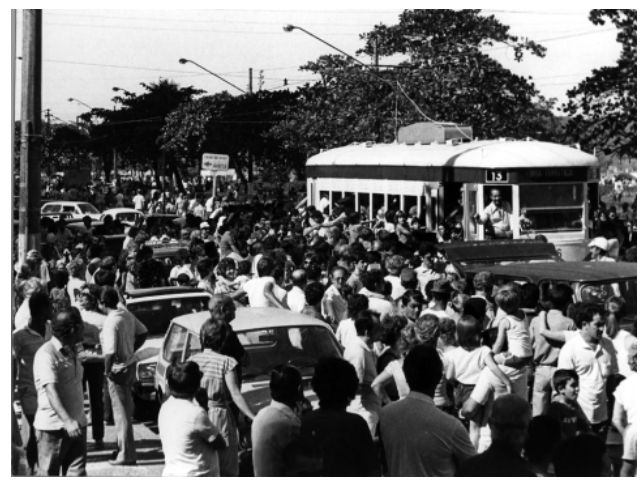

Primeira tentativa de reativar o Bonde como atração turística em Santos, na orla da praia, pelo prefeito Paulo Barbosa. 10 de junho de 1984. Gelatina/prata, $10 \times 15 \mathrm{~cm}$. Acervo FAMS.

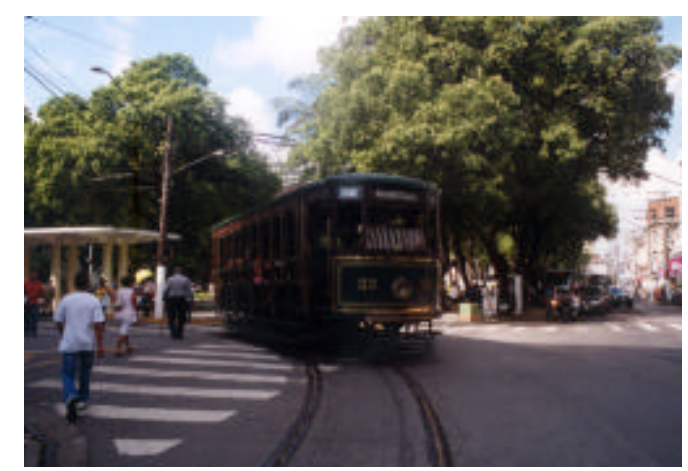

Bonde Turístico aberto. Centro Histórico de Santos. Abril de 2007. Gelatina/prata, $13 \times 15 \mathrm{~cm}$. Acervo particular José Herrera.

\footnotetext{
${ }^{274}$ LICHTI, Fernando Martins, História de Santos - Poliantéia Santista, 1996, p.115.
} 


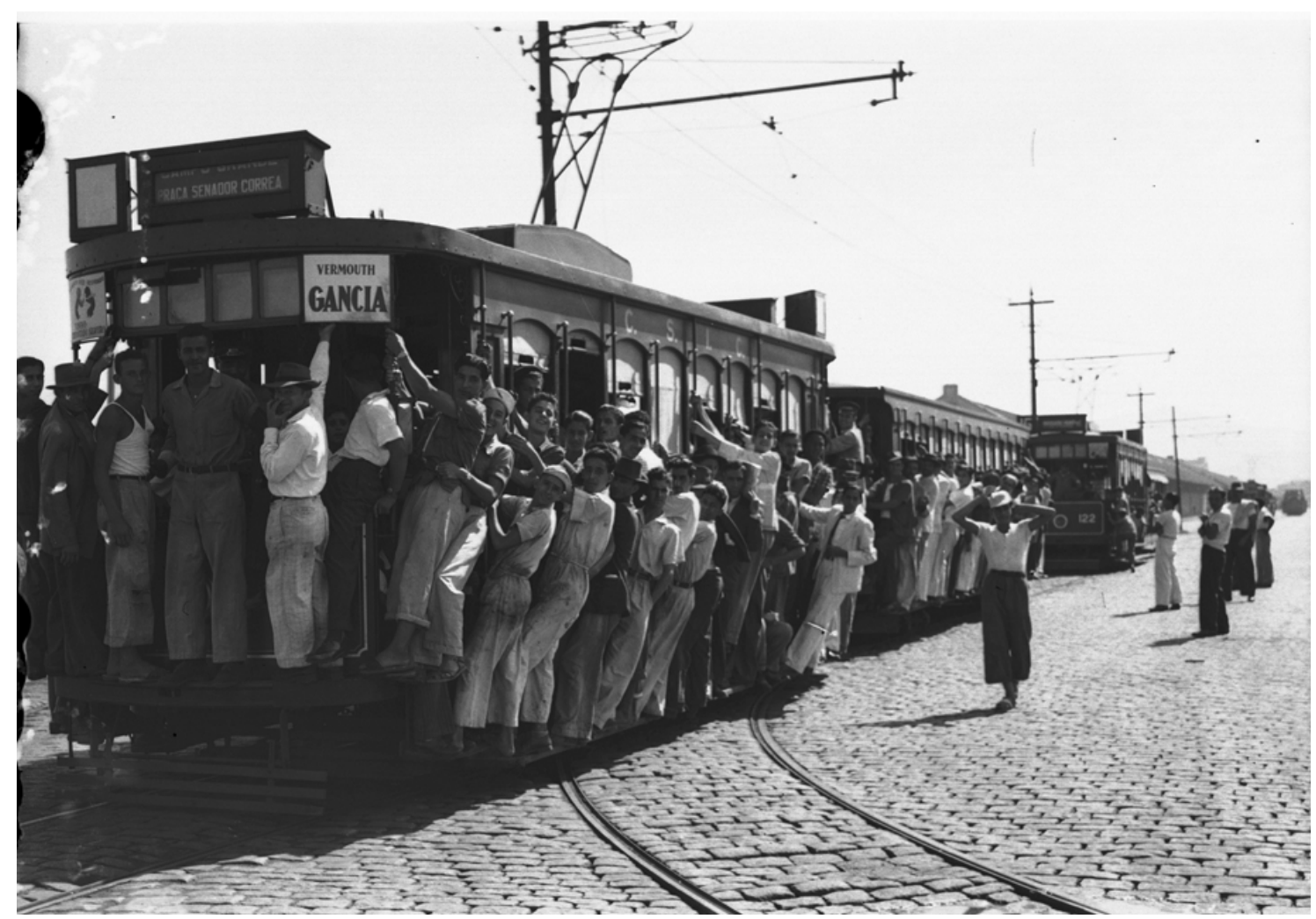

Bonde 19 com reboque circulando no Porto de Santos, no início da década de 1940.

A imagem mostra o Bonde $n .^{\circ} 19 \mathrm{com}$ reboque, transportando, principalmente, trabalhadores do Porto, no início da década de 1940. A lotação do bonde indica que os passageiros estavam em horário de entrada, saída ou de almoço do trabalho. Seu itinerário compreendia o trajeto da Praça Corrêa de Melo, no Bairro do Valongo, até o Macuco, perto do Porto. Nota-se que a rua é de paralelepípedo e que, na parte de cima do veículo, existem dois anúncios: um à esquerda, não identificado, e outro à direita, da bebida Vermouth Gancia, uma das mais famosas da época. Segundo Fernando Martins Lichti, o serviço de anúncios nos bondes, tanto internamente como por fora, foi inaugurado em 4 de janeiro de 1942 e a concessionária para essa promoção era a Cia. Interestadual de Propaganda. ${ }^{275}$

\footnotetext{
${ }^{275}$ LICHTI, Fernando Martins, História de Santos - Poliantéia Santista, 1996, p.115.
} 
José Herrera relembra o trajeto da linha 19, destacando que, no reboque, o passageiro pagava mais barato:

O bonde 19 servia a parte do cais. Era uma linha extensa, que saía do Macuco e ia até o Valongo fazendo várias paradas em bairros mais pobres, onde as pessoas não tinham carro. Por isso, lotava demais, principalmente na hora do almoço e de saída do serviço... A maioria dos passageiros que pegava o 19 era de trabalhadores do Porto e do Centro da Cidade. ${ }^{276}$

Sobre os reboques, Lichti esclarece que, em 1931, a "Cia. City”, concessionária dos serviços de transporte de bonde, começou a construir carros grandes, de 60 lugares.

Esses bondes, com maior potência, permitiram 0 aproveitamento dos primitivos carros de tração animal, utilizando-os como reboques, pois eram manuseados com simples engates acoplados aos bondes elétricos, nas linhas ou horários de maior movimento. Os 'reboques' permaneceram em uso, praticamente, até os últimos dias dos bondes em Santos. ${ }^{277}$

Além de realizar o transporte de cargas e passageiros, existiram outros vários tipos de bonde como o "fúnebre", que surgiu em 1903 e levava o caixão e seus acompanhantes até o cemitério, o "irrigador", montado para limpeza e lavagem das ruas, em princípios de 1913, e o "assistência", que levava auxílio aos bondes que quebravam durante os trajetos.

O último bonde a sair de circulação foi o veículo prefixo 258, da linha 42, que ia da Praça Mauá, no Centro, à Ponta da Praia, pela Avenida Ana Costa. O carro foi recolhido à garagem no dia 28 de fevereiro de 1971. No ano de 1984, a Prefeitura Municipal fez a primeira tentativa de trazer o Bonde de volta, como atração turística.

\footnotetext{
${ }^{276}$ Depoimento do fotógrafo. 09/03/2006.

${ }^{277}$ LICHTI, Fernando Martins, História de Santos - Poliantéia Santista, 1996, p.115.
} 
O veículo circulou até 1986 e hoje está parado na Praça das Bandeiras, no Gonzaga, servindo como posto de informação turística.

Depois da tentativa frustrada, a Prefeitura resolveu implantar a atração no Centro Histórico da Cidade. A Linha Turística do Bonde foi inaugurada a 23 de setembro de 2000 e hoje é uma das principais atrações de Santos. Com 1.700 metros, realiza um passeio de 15 minutos e mantém em funcionamento três bondes: o primeiro é um veículo escocês aberto de 1909, inaugurado junto com a linha; o segundo é um bonde-camarão, também escocês, de 1911, entregue à população em 26 de janeiro de 2002; e o terceiro é um bonde português, doado pela cidade do Porto, que foi inaugurado em 26 de janeiro de 2006 e deu início ao Museu Vivo do Bonde. ${ }^{278}$ Quando o movimento de passageiros é intenso, um bonde reboque é colocado em funcionamento também.

Durante o passeio, os passageiros são monitorados por guias bilíngües que recordam as histórias dos lugares por onde passam. No ponto do Bonde, antes da partida, integrantes do programa "Vovô Sabe Tudo"279 organizam o embarque e ficam à disposição dos interessados para contar curiosidades sobre este meio de transporte. Em setembro de 2006, foram iniciadas as obras de ampliação da linha, que passará para 5 km e terá vários pontos de embarque e desembarque.

\footnotetext{
${ }^{278}$ Bondes de diversos países circulando pela Linha Turística. A vinda de mais veículos já está sendo negociada e a expectativa da Prefeitura é que, em breve, estarão circulando mais dois bondes portugueses, um italiano, um paraguaio, um japonês e um dos Estados Unidos.

279 Idosos que trabalharam como motorneiros ou condutores de bonde em Santos.
} 


\subsection{3 - LIMPEZA PÚBLICA}

Até 1975, a limpeza pública em Santos era realizada exclusivamente pela Prefeitura Municipal, que não conseguia garantir um serviço eficiente. Por isso, no ano seguinte, o serviço foi transferido para a Prodesan ${ }^{280}$, que passou a ser responsável pela coleta de lixo urbano e limpeza das praias e de logradouros públicos, incluindo varrição, capinação e limpeza de valas.

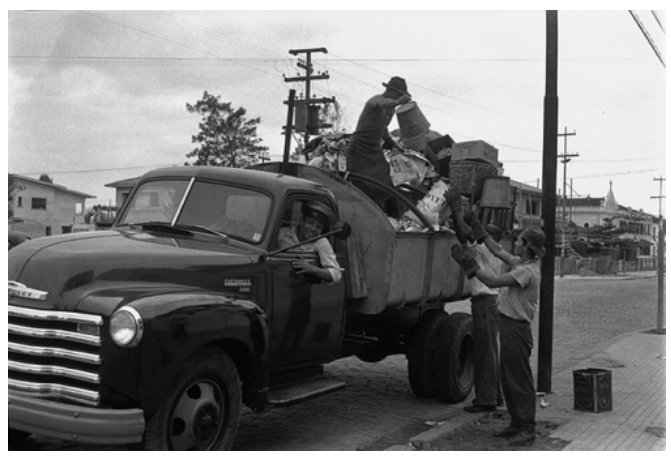

Caminhão de coleta de lixo residencial. Santos, início da década de 1950. Gelatina/prata, $6 \times 6 \mathrm{~cm}$. Acervo FAMS.

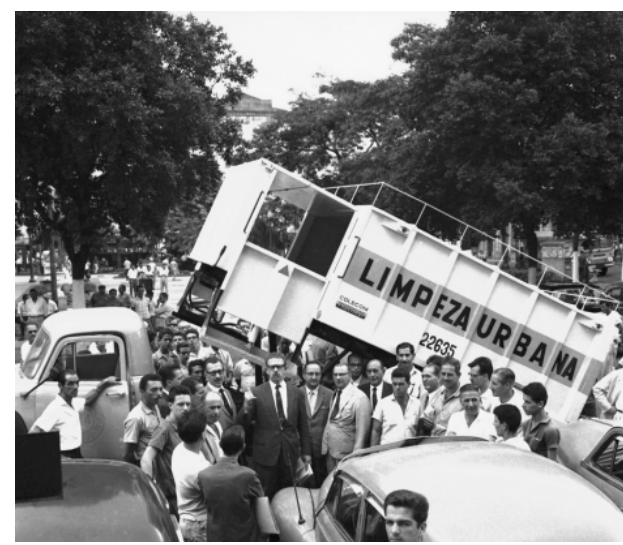

O prefeito José Gomes entregando os novos caminhões de coleta de lixo, em frente à Prefeitura. Praça Mauá, Santos, 1963. Gelatina/prata, $6 \times 9 \mathrm{~cm}$. Acervo FAMS.

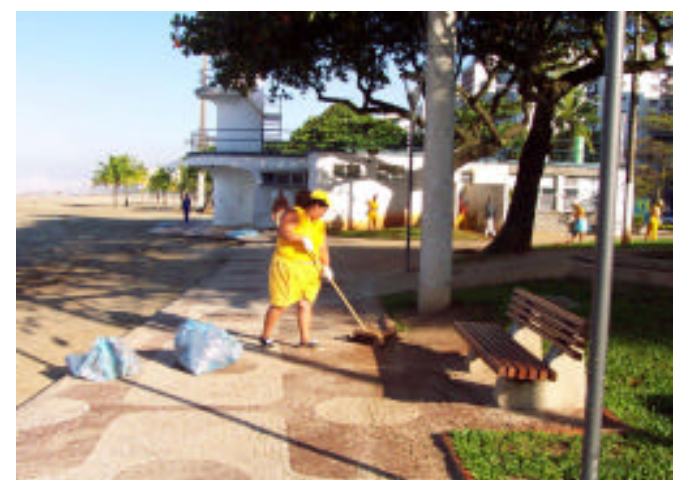

As chamadas 'margaridas' realizando serviços de limpeza nos jardins e calçadões da orla da praia. Santos. 27 de abril de 2004. Imagem digital. Acervo Secom.

\footnotetext{
${ }^{280}$ Progresso e Desenvolvimento de Santos - empresa de economia mista em que a Prefeitura de Santos detém capital majoritário.
} 


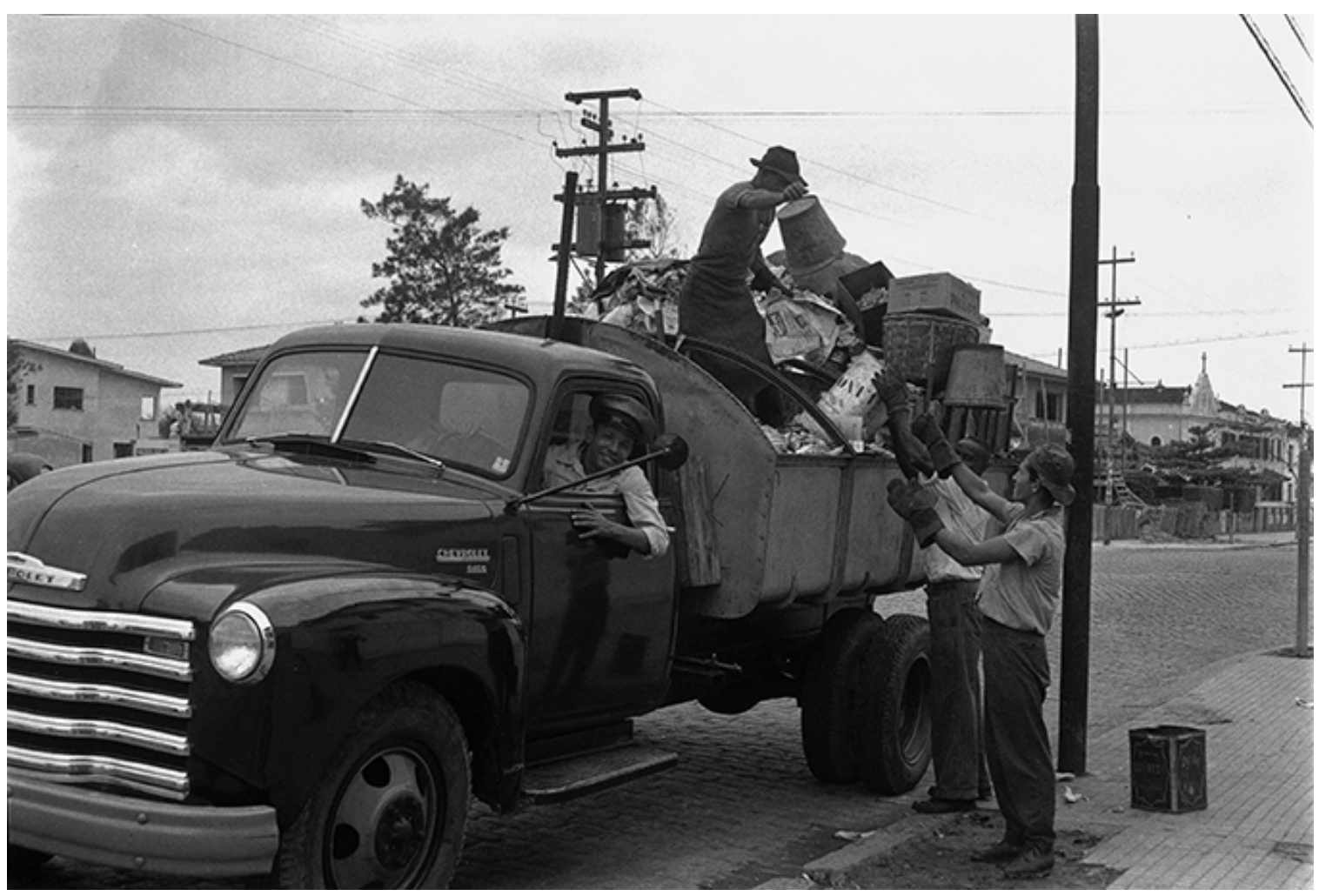

Caminhão Chevrolet Tigre ano 1951 utilizado na coleta de lixo residencial em Santos.

Podemos perceber na imagem que a caçamba do caminhão é adaptada para que o veículo possa ser utilizado como caminhão de lixo. Vemos também que o caminhão é aberto e deixa o lixo exposto, e que os funcionários trabalham com um uniforme pouco apropriado: calça, camiseta de manga curta e sapatos. Embora os lixeiros que estão na calçada usem luvas, nota-se que o funcionário em cima do caminhão tem uma de suas mãos desprotegida. A imagem mostra também que a coleta está sendo feita em local próximo à entrada da Cidade. A rua é larga e feita de paralelepípedos, existem somente casas na via e a calçada está danificada. $\mathrm{Na}$ época, a limpeza pública era de responsabilidade da Prefeitura Municipal, por meio da Diretoria de Serviços Públicos.

Ao rever as imagens da década de 1950, José Herrera lembra do tempo em que morava na Rua Marquês de São Vicente, $n^{\circ} .50$ : 
Os caminhões de lixo naquela época eram totalmente abertos, mas não cheiravam mal. O lixeiro passava todos os dias pela manhã, menos aos domingos. A gente colocava o lixo na frente de casa em latões de tinta, sem saco, sem nada, e eles (os lixeiros), despejavam no caminhão direto [...] Nem tinham inventado saco de lixo ainda. 281

Atualmente, a Prodesan é responsável pela gerência, fiscalização e administração dos serviços de limpeza pública, que são executados pela Terracom Engenharia Ltda., desde 1998. A empresa utiliza equipamentos de última geração para garantir a eficiência de seus serviços e facilitar o trabalho de seus funcionários, tais como tratores, escavadeiras, caminhões e veículos de grande, médio e pequeno porte.

Dentre as obrigações da Terracom estão a execução de todas as etapas de destinação dos resíduos domiciliares e industriais, rastelação manual e mecânica da faixa de areia das praias, limpeza de sanitários e quiosques de logradouros públicos, varrição e raspação de ruas, guias e sarjetas, limpeza de canais, mercados municipais e feiras livres e capinação química. ${ }^{282}$

\footnotetext{
281 Depoimento do fotógrafo. 26/11/ 2007.

282 www.prodesan.com.br/limpezapublica
} 


\subsection{4 - EXPLOSÃO DO GASÔMETRO}

Na madrugada de 09 de janeiro de 1967, o reservatório de gás santista - o Gasômetro -, localizado no bairro Vila Nova, explodiu destruindo dezenas de prédios e casas nas redondezas e deixando cerca de 300 feridos. Desde então, o fornecimento de gás encanado para Santos deixou de existir, dando lugar aos botijões de gás liquefeito de petróleo (GLP). Em 2006, a construção de uma nova rede de distribuição de gás em Santos foi autorizada pela Administração Municipal.

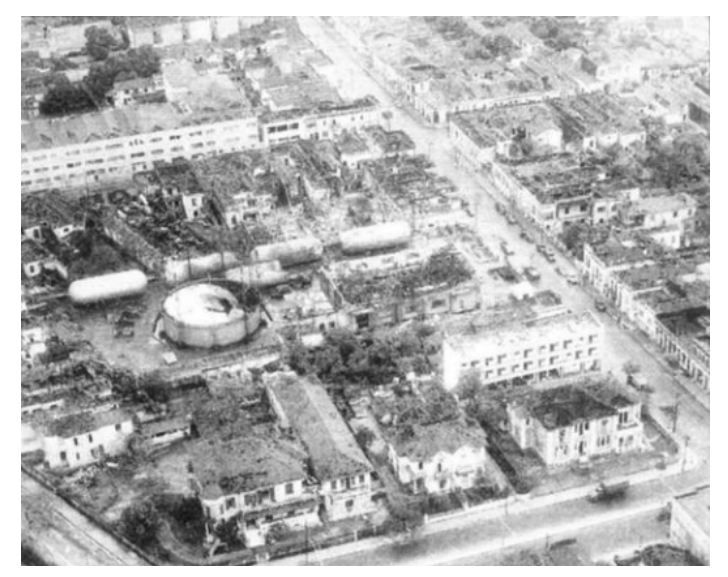

Panorâmica do Feservatório de Gás após explosão, em janeiro de 1967. Reprodução do jornal A Tribuna.

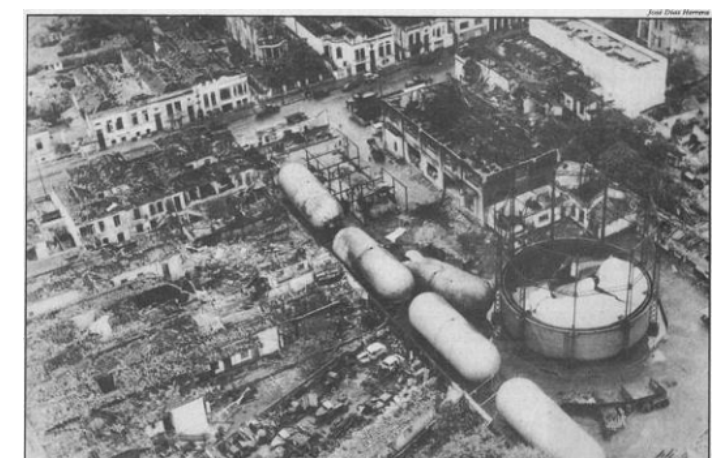

Panorâmica do Reservatório de Gás após explosão, em janeiro de 1967. Reprodução jornal A Tribuna. 


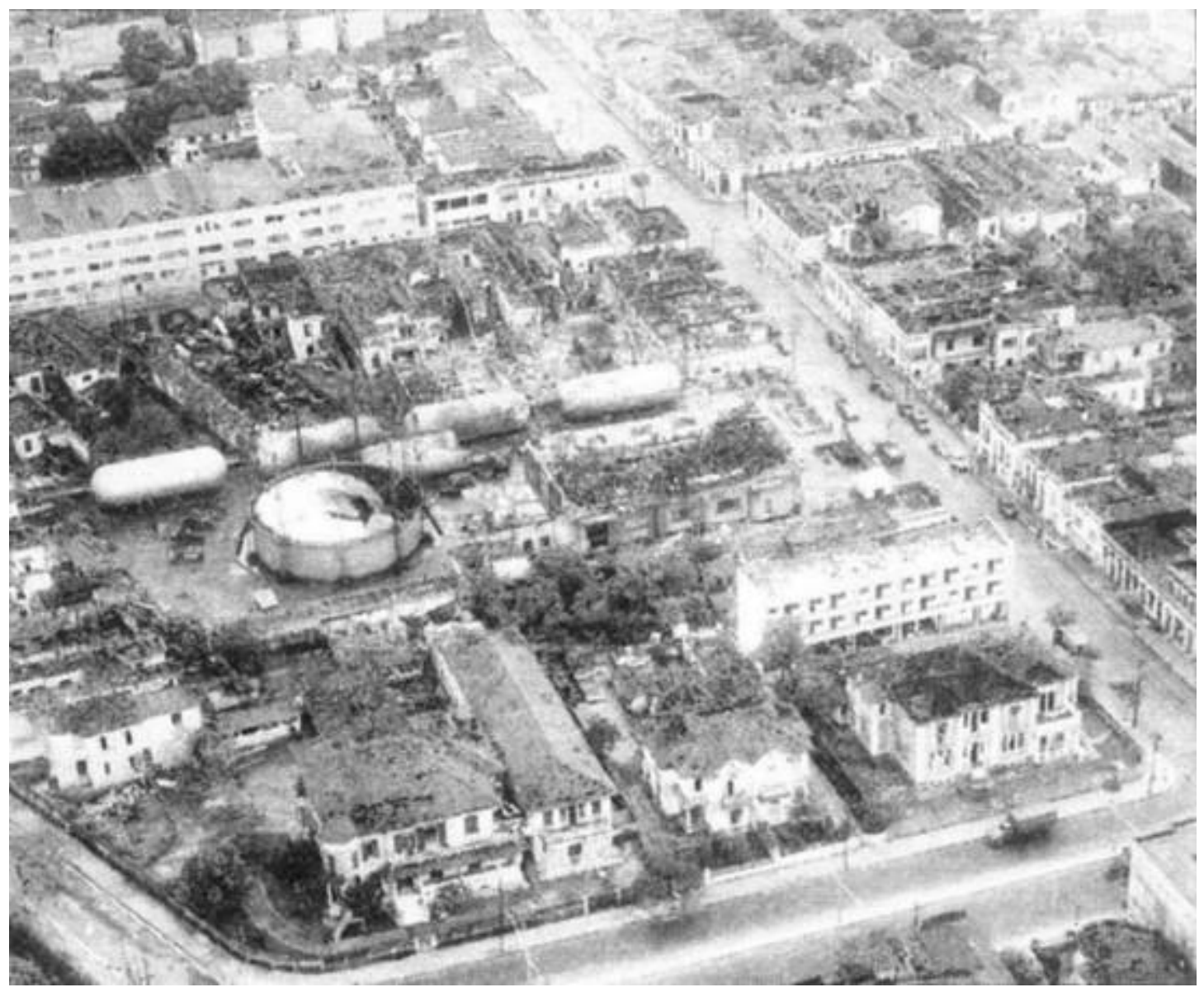

Panorâmica do Reservatório de Gás após explosão, em janeiro de 1967.

A imagem nos dá uma visão panorâmica do local do acidente e mostra todo o quarteirão onde estava localizado o Gasômetro (Reservatório de Gás da Cidade de Santos - Serviços de Eletricidade e Gás S/A). A via à esquerda é a Avenida Campos Sales. À direita, vê-se a Rua Marechal Pego Júnior e, abaixo, a Avenida Conselheiro Nébias. Podemos identificar os cinco reservatórios existentes - quatro em forma de cápsula e um maior circular. Próximo aos reservatórios, notamos que casas e prédios tiveram telhados, portas, janelas e paredes destruídos. A explosão e o clarão puderam ser percebidos a vários quilômetros de distância, como afirma o fotógrafo José Herrera:

Eu estava dormindo e escutei uma explosão horrível, saí correndo até um ponto de táxi. Os motoristas tinham visto de onde 
tinha vindo o clarão. Fomos pra lá. Quando cheguei ainda tinha fogo no local. ${ }^{283}$

Apesar da proporção da tragédia, que afetou residências, colégios e até o QG do Exército, nenhuma morte foi registrada. ${ }^{284}$ Até aquela ocasião, o Município contava com fornecimento de gás encanado residencial, sendo uma das primeiras cidades do País a contar com o serviço, implantado a partir de 1870. Dois dias após a explosão, o jornal $A$ Tribuna destacava a grande procura por fogões a gás engarrafado. $\mathrm{O}$ acidente mudou o perfil do abastecimento de gás em Santos e em toda a região. O serviço encanado foi encerrado após a tragédia. ${ }^{285}$

Em 2006, a Prefeitura de Santos autorizou a implantação de um projeto de gasodutos na Cidade pela Companhia de Gás de São Paulo (Comgás), concessionária do serviço na Baixada Santista. Segundo a empresa, a nova rede possui um sistema moderno e seguro, que não armazena o gás, e sim, o traz direto dos pontos de captação. Em 2008, a população santista já poderá contar com os serviços de distribuição de gás natural. ${ }^{286}$

\footnotetext{
283 Depoimento do fotógrafo. 07/03/2005.

${ }^{284}$ A cidade nunca viu algo semelhante, $A$ Tribuna, Santos, 10 de janeiro de 1967, p.24.

${ }^{285}$ Aumenta procura por gás engarrafado. A Tribuna, Santos, 11 de janeiro de 1967, p.2

${ }^{286}$ Santistas deverão ter gás natural em um ano. A Tribuna, Santos, 28 de julho de 2006, p. A4.
} 


\subsection{Lazer e Cultura}

Lazer nunca faltou na Baixada Santista, principalmente em Santos e Guarujá. As praias da região sempre atraíram turistas de todo o Estado e, até a década de 1950, os cassinos estavam entre as opções mais procuradas por aqueles que queriam diversão. José Herrera lembra da quantidade de cassinos que funcionavam na região:

Em Santos, além do Monte Serrat, tinha o cassino do Atlântico, do centro recreativo Miramar... No Guarujá, tinha o cassino do Grande Hotel, e até em São Vicente existia cassino... Eu não jogo, sou contra jogo, mas tenho que admitir que os cassinos eram importantes porque atraíam muitos turistas, e turistas de dinheiro. ${ }^{287}$

A cidade de Santos também foi berço cultural de inúmeros escritores e artistas, de teatro, televisão e cinema. Na Cidade, nasceram ou foram revelados Patrícia Galvão, Plínio Marcos, Cacilda Becker, Cleide Yáconis, Ney Latorraca e tantos outros. Além disso, o Porto santista foi a porta de entrada de inúmeras celebridades estrangeiras que vieram se apresentar no Brasil, como o maestro italiano Arturo Toscanini e o cantor americano Nat King Cole, ambos fotografados pelas lentes de Herrera.

${ }^{287}$ Depoimento do fotógrafo. 30/11/2005. 


\subsection{1 - PRAIA DO GUARUJÁ}

No início dos anos de 1950, José Herrera foi cedido pelo jornal O Diário, nos finais de semana, para a revista $O$ Cruzeiro, do Rio de Janeiro, para cobrir os eventos no Grande Hotel La Plage, do Guarujá, localizado na Praia das Pitangueiras. Durante o dia, a maioria dos hóspedes fotografados eram mulheres, que gostavam de ser "clicadas" na praia, onde o hotel montava mesas e oferecia atividades recreativas: jogos de vôlei, ginástica etc.

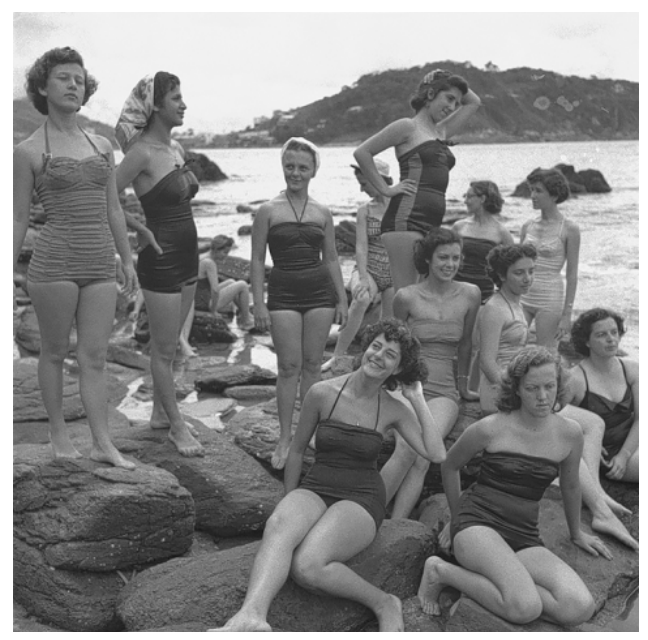

Banhistas na praia das Pitangueiras, no Guarujá Meados de década de 1950. Gelatina/prata, $6 \times 6 \mathrm{~cm}$. Acervo FAMS.

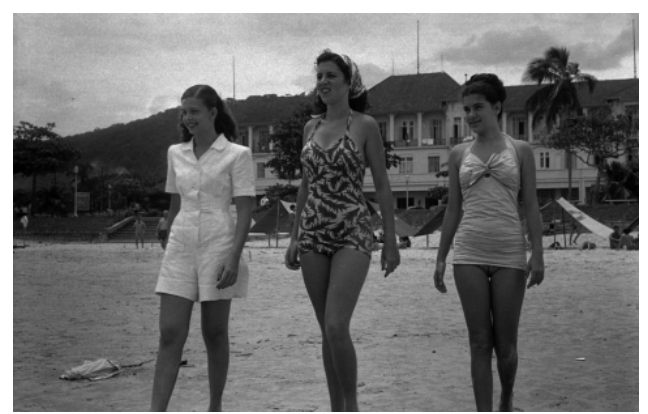

Banhistas e hóspedes do Grande Hotel La Plage, no Guarujá, com o hotel ao fundo. Meados da década de 1950. Gelatina/prata, 6x6cm. Acervo 


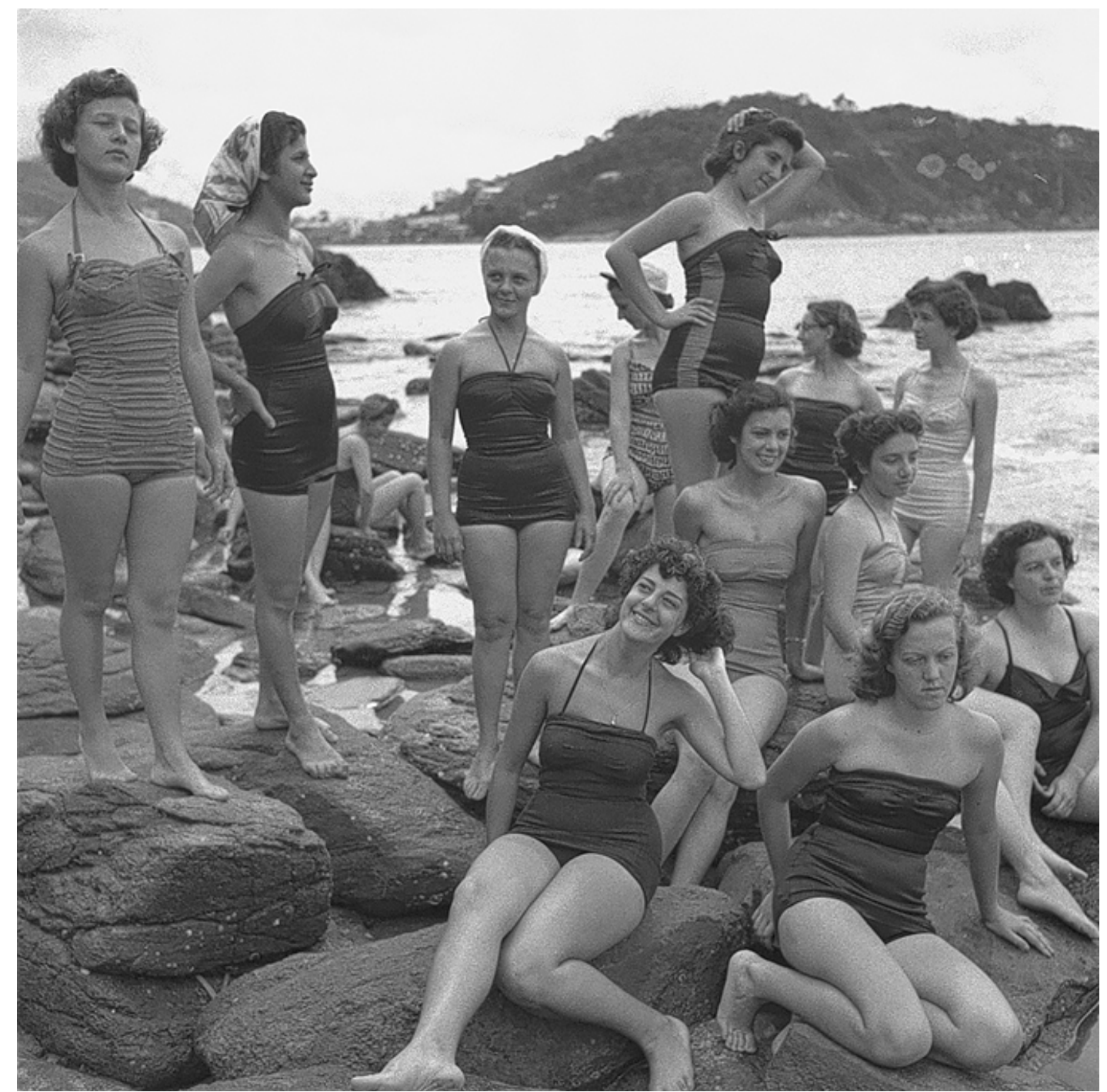

Grupo de moças durante manhã de recreação na praia das Pitangueiras, no Guarujá, em meados de década de 1950.

Como mostra a imagem, todas estão trajando maiôs bem comportados: inteiros, escuros e lisos. As peças eram confeccionadas em helanca ${ }^{288}$ ou nylon, que afinava a cintura, realçava os quadris, ajustava-se melhor ao corpo e era privilégio das mais abastadas, por serem caras e geralmente feitas sob medida. A lycra surgiu no final da década de 1970. Vale ressaltar também que, apesar do biquíni ter sido desenhado no ano de 1946, a peça só começou a ser usada como item básico a partir de 1970. Até então, o modelo era considerado "um escândalo".

\footnotetext{
${ }^{288}$ Malha mais grossa, normalmente usada em roupas de educação física.
} 
José Herrera lembra que o Guarujá era freqüentado somente por famílias influentes e pessoas importantes da sociedade paulista, além de artistas, políticos e celebridades de todo o País:

Eu passava as manhãs na praia fotografando as hóspedes do Grande Hotel para a parte social da revista O Cruzeiro. Elas adoravam fazer pose e até simulavam algumas situações: fingiam estar jogando alguma coisa, fingiam estar distraídas[...] Às vezes, alguns banhistas que estavam por ali frequentando o mesmo pedaço me pediam para fotografá-los. Eu até fotografava para agradar, mas não enviava as imagens para a revista. Claro que não! ${ }^{289}$.

${ }^{289}$ Depoimento do fotógrafo. 17/03/2006. 


\subsection{2 - CASSINO DO MONTE SERRAT}

Situado 147 metros acima do nível do mar, o antigo cassino do Monte Serrat foi inaugurado em 3 de setembro de 1927 e funcionou até 1946, quando o jogo foi proibido em todo País. Hoje, o lugar é atração turística e de seu terraço é possível ver toda a cidade de Santos e partes de Vicente de Carvalho e Guarujá. O cassino pertencia à mesma empresa proprietária dos famosos bondinhos funiculares do Monte Serrat, que atualmente tem o nome de Monte Serrat - Cassino Elevadores Ltda.

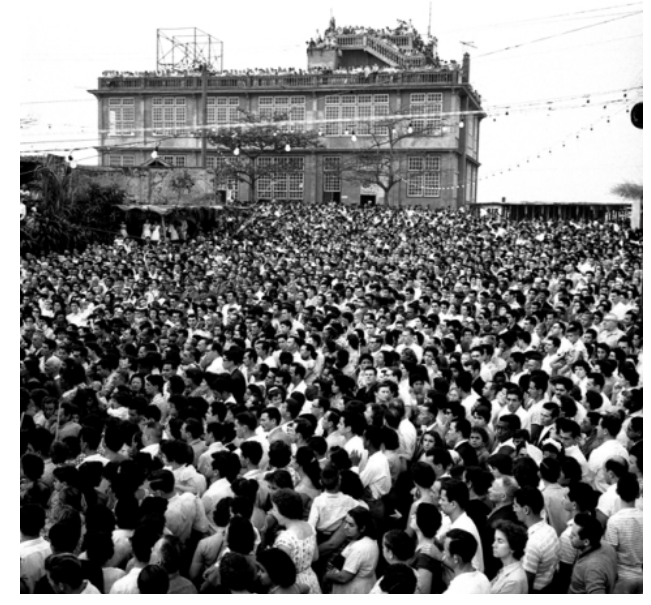

Prédio do antigo cassino do Monte Serrat. Santos. 08 de setembro de 1958. Gelatina/prata, $6 \times 9 \mathrm{~cm}$. Acervo FAMS.

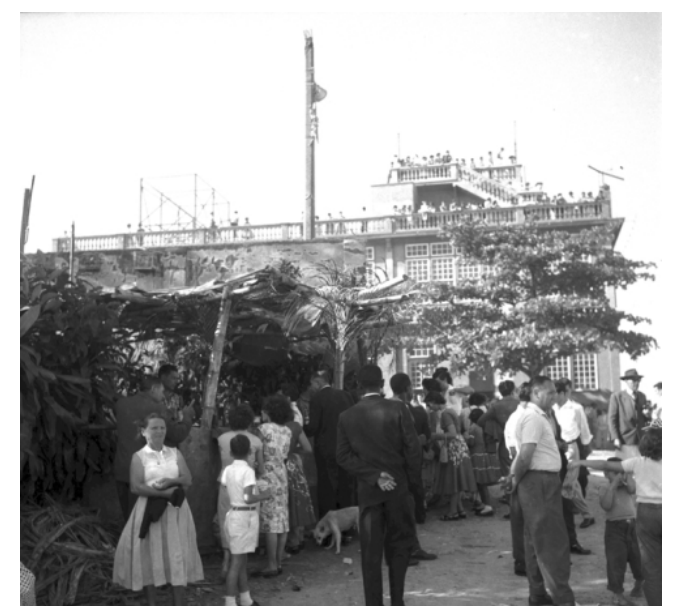

Prédio do antigo cassino do Monte Serrat. Santos. 08 se setembro de 1958 . Gelatina/prata, $6 \times 9 \mathrm{~cm}$. Acervo FAMS. 


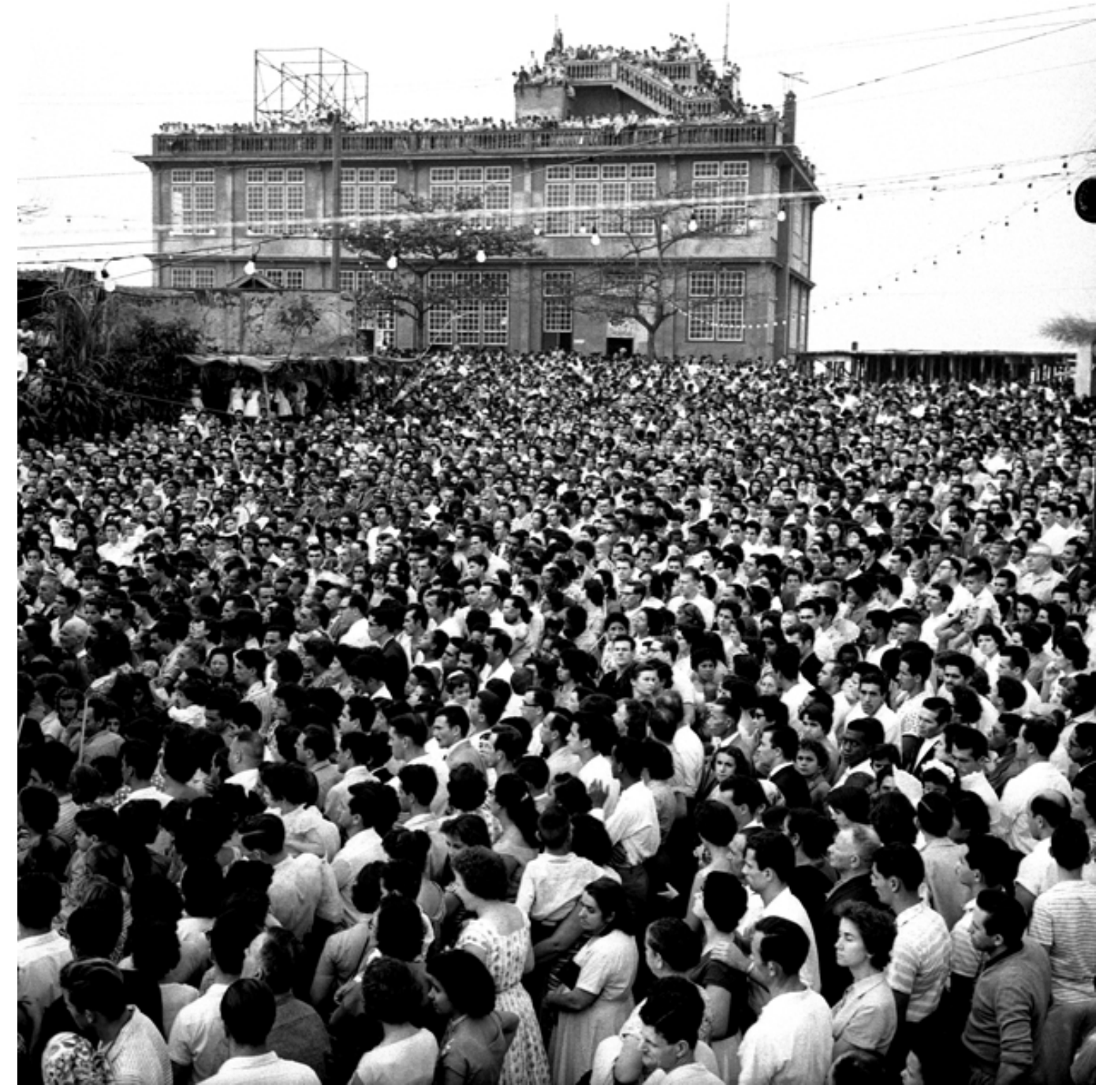

Prédio do antigo cassino do Monte Serrat, em 08 de setembro de 1958.

A imagem mostra o prédio do antigo cassino do Monte Serrat, ao fundo, ainda sem o mirante que existe hoje. Como a foto tirada no dia 08 de setembro de 1958 , durante as comemorações do dia de Nossa Senhora do Monte Serrat, padroeira da cidade de Santos, percebemos o local com grande movimentação de pessoas, provavelmente assistindo à missa campal, em frente à capela da santa. José Herrera comenta:

Os salões do cassino eram belíssimos, todos decorados com tapetes e cortinas. Lá aconteciam grandes bailes e apresentações luxuosas... O lugar realmente movimentava a Cidade... Mas eu não freqüentava o cassino, nunca freqüentei, não gostava. Trabalhei muito tempo fotografando e nunca fiz um jogo. Eu preservo o meu 
dinheiro. O meu dinheiro era dinheiro de sacrifício, para ajudar a família e pagar minhas contas, e não para perder no jogo. ${ }^{290}$

O jornal $A$ Tribuna, de $1^{\circ}$ de maio de 1946 , destacou a assinatura do Decreto

n. ${ }^{\circ}$ 9215, assinado no dia anterior, que proibiu o jogo no Brasil:

Rio, 30 (Especial) - Esteve hoje reunido o Ministério, sob a presidência do general Gaspar Dutra. Durante a reunião, segundo soube a reportagem, debateu-se a questão do jogo e, afinal, concretizou-se aquilo que até há pouco era tido como simples boato. Durante a reunião, o presidente da República assinou um decreto-lei extinguindo os jogos de azar em todo o território nacional... A notícia sobre a extinção do jogo teve forte repercussão nesta capital e 0 efeito de uma 'bomba atômica', usando-se a linguagem em voga. ${ }^{291}$

Sobre a proibição do jogo, o fotógrafo lembra da tristeza da população:

Mas, para mim, não afetou em nada, eu não jogava mesmo. $\mathrm{O}$ ruim é que teve muita gente desempregada e a cidade também perdeu porque o cassino atraía muita gente de fora. Por outro lado foi bom, porque eu vi muita gente perder até as calças lá dentro". ${ }^{292}$

O jornal A Tribuna confirma o comentário de Herrera:

'O Dia do Trabalho' veio encontrar este ano a cidade de Santos com alguns milhares de desempregados constituídos pelos funcionários de casinos, que vêm de ser fechados em virtude da extinção do jogo em todo o território nacional... Não são entretanto, somente os trabalhadores de casinos que sofrerão as conseqüências. Os restaurantes e hotéis terão seu movimento reduzido... As lavanderias, tinturarias, garages, alfaiatarias, sapatarias, estabelecimentos comerciais em geral, todos sofrerão uma redução de seu movimento, e cada um deles fornecerá o seu contingente à legião de desempregados que serão muitos milhares. ${ }^{293}$

\footnotetext{
${ }^{290}$ Depoimento do fotógrafo. 30/11/2005.

${ }^{291}$ A extinção do jogo - comentários em torno do decreto-lei de ontem, do governo federal. A Tribuna, Santos. 01 de maio de 1946, p.1.

292 Depoimento do fotógrafo. 30/11/2005.

293 As praias de Santos sem jogo - Havia ontem por toda a parte uma atmosfera de melancolia e tristeza. A Tribuna. Santos. 03 de maio de 1946, p.14.
} 


\subsection{3 - CASSINO DO GRANDE HOTEL DO GUARUJÁ}

Trabalhando na década de 1950 como free lancer para a revista O Cruzeiro, do grupo Diários Associados, José Herrera acompanhou muitos shows e apresentações que aconteceram no cassino que funcionava anexo ao prédio do Grande Hotel La Plage, do Guarujá. Além dos eventos, ele fotografava as autoridades e personalidades que freqüentavam o lugar. Este foi um dos trabalhos mais rentáveis que o fotógrafo conseguiu.

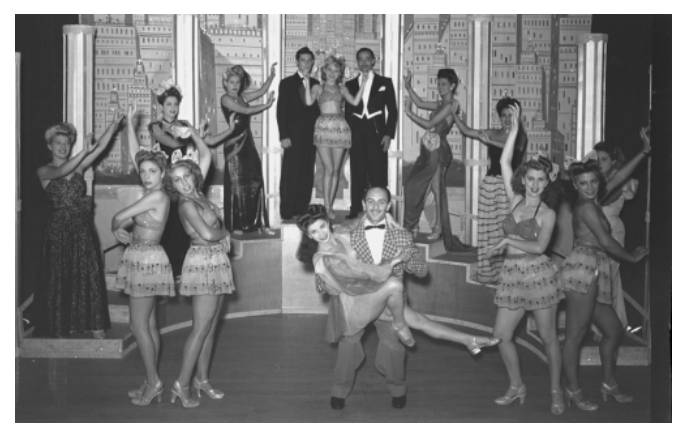

Show no cassino do Grande Hotel La Plage.

Guarujá. Meados da década de 1950.

Gelatina/prata, $6 \times 6 \mathrm{~cm}$. Acervo FAMS.

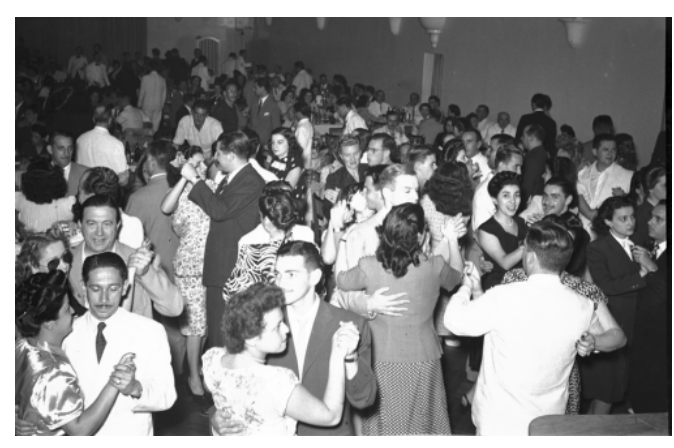

Baile no salão do cassino do Grande Hotel La Plage. Guarujá. Meados da década de 1950. Gelatina/prata, $6 \times 6 \mathrm{~cm}$. Acervo FAMS. 


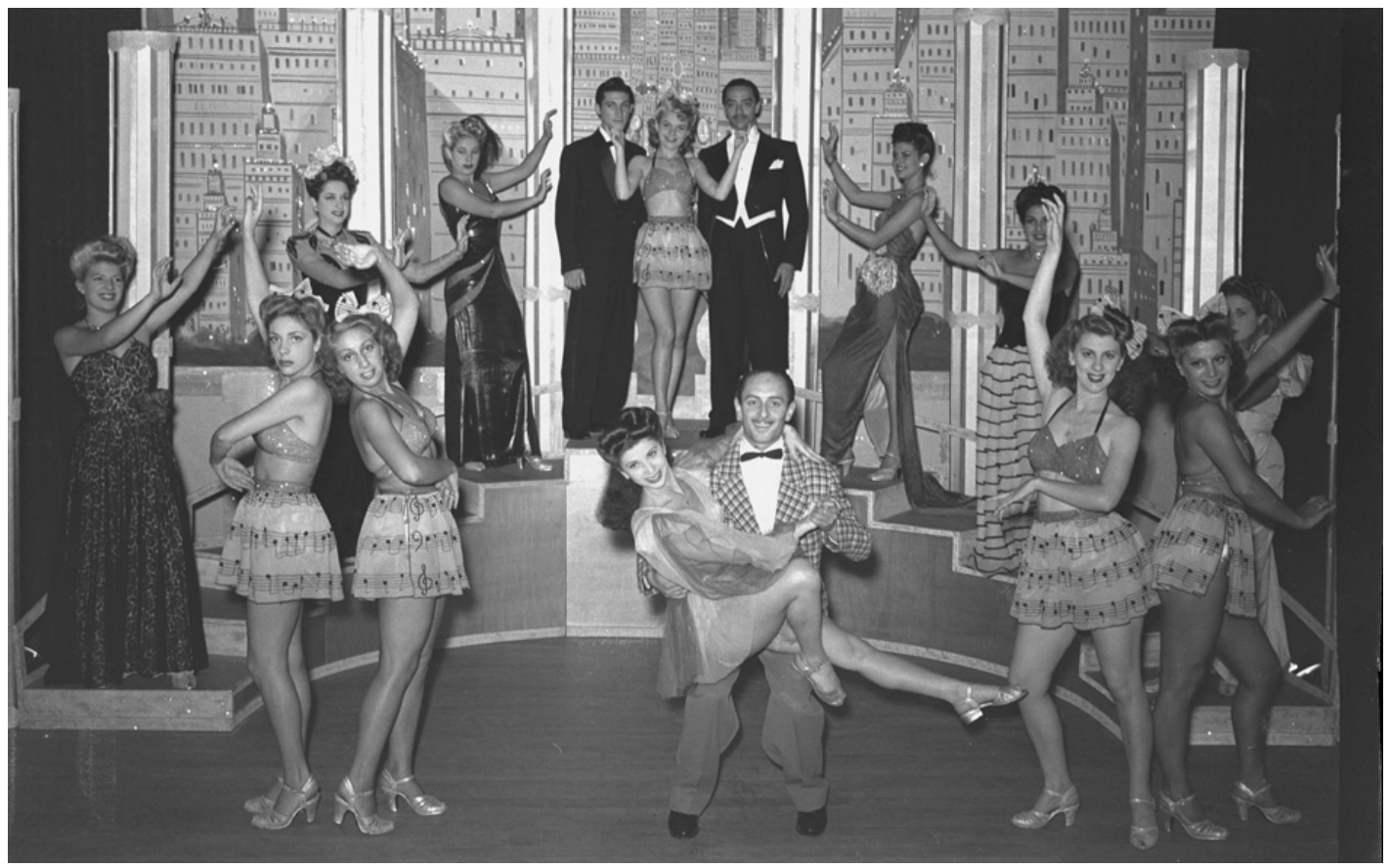

Show no cassino do Grande Hotel La Plage., no Guarujá, em meados da década de 1950.

Como podemos observar, trata-se de uma foto posada antes do início de uma apresentação de Teatro de Revista, no salão do cassino do Grande Hotel La Plage do Guarujá, em meados da década de 1950. Na imagem, notam-se as características deste tipo de espetáculo, que tinha acompanhamento musical: grandes coreografias, cenário suntuoso e figurino ousado (mini saia e top, com a barriga de fora), valorizando o corpo da mulher. Posam para a foto 15 atores, dos quais apenas três são homens. Esclarece José Herrera:

Eles tinham que posar antes do show porque eu não podia tirar a fotografia durante o espetáculo por causa da fumaça que o magnésio produzia... Eu não podia atrapalhar a apresentação e nem o público. Ah! Outra coisa: tudo acontecia no cassino sim, mas não usavam a palavra 'cassino' para evitar problemas, pois o jogo era proibido. $^{294}$

${ }^{294}$ Depoimento do fotógrafo. 17/03/2006. 
O fotógrafo comenta também como era o seu final de semana trabalhando no Grande Hotel do Guarujá, reduto da elite praiana:

Aos finais de semana, eu ficava no hotel, onde havia muitos shows de artistas estrangeiros. Eu tinha uma mesa especial reservada no salão onde eu sentava com a máquina e esperava as recomendações do gerente. A gente tinha que levar caixas e caixas de lâmpadas para usar a noite inteira, porque cada lâmpada só disparava uma vez. Tirava umas 60 fotos brincando. Mas pensa que era só mandar os negativos? Corria para o laboratório do jornal, revelava, ampliava, voltava ao hotel para que o gerente identificasse as pessoas e só depois enviava para a revista, lá no Rio de Janeiro. Mas valeu a pena. Ganhei um dinheirão. Eles publicavam sete, oito, dez páginas só com fotos minhas. ${ }^{295}$

Infelizmente, aos poucos, o Teatro de Revista começou a apelar fortemente para o escracho e para o nu explícito, em detrimento de um de seus alicerces: a comicidade. Assim, entrou em um período de decadência, praticamente desaparecendo no final da década de 1960. A pesquisadora Neyde Veneziano assim resume a alma e a importância do Teatro de Revista:

Ao se falar em teatro de revista, que nos venham as idéias de vedetes, de bananas, de tropicália, de irreverência e, principalmente, de humor e de música, muita música. Mas que venha também a consciência de um teatro que contribuiu para a nossa descolonização cultural, que fixou nossos tipos, nossos costumes, nosso modo genuíno do 'falar à brasileira'. Pode-se dizer, sem muito exagero, que a revista foi o prisma em que se refletiram as nossas formas de divertimento, a música, a dança, o carnaval, a folia, integrando-os com os gostos e os costumes de toda uma sociedade bem como as várias faces do anedotário nacional combinadas ao (antigo) sonho popular de que Deus é brasileiro e de que o Brasil é o melhor país que há. ${ }^{296}$

\footnotetext{
295 Depoimento do fotógrafo. 17/03/2006.

296 VENEZIANO, Neyde. O teatro de revista. In: O TEATRO através da história. Rio de Janeiro: Centro Cultural Banco do Brasil, 1994. p. 154 et seq.
} 


\subsection{4 - O PAGADOR DE PROMESSAS}

O filme brasileiro "O Pagador de Promessas" foi vencedor de cinco prêmios internacionais, com destaque para a Palma de Ouro em Cannes, na França, em maio de 1962. Após o recebimento do prêmio em Cannes, o diretor e a equipe desembarcaram do transatlântico "Augustus" no Porto de Santos e se dirigiram para - Centro de Cidade, onde foram homenageados pelo grupo A Tribuna e pela Municipalidade.

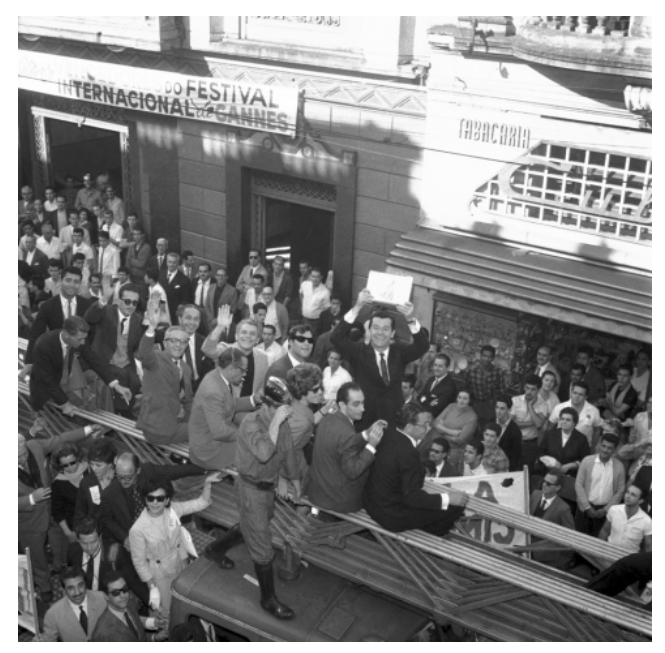

Elenco do filme "O Pagador de Promessas" desfilando em caminhão do Grupamento de Bombeiros pela Rua João Pessoa, acenando para o povo e para a imprensa. Santos, Julho de 1962. Gelatina/prata, $6 \times 9 \mathrm{~cm}$. Acervo particular José Herrera.

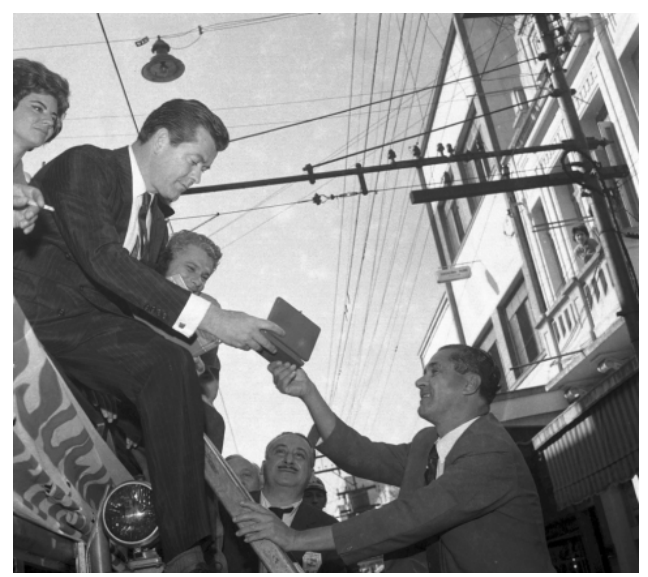

Anselmo Duarte, diretor do filme, recebendo uma placa de um jornalista. Santos, Julho de 1962. Gelatina/prata, $6 \times 9 \mathrm{~cm}$. Acervo particular José Herrera. 


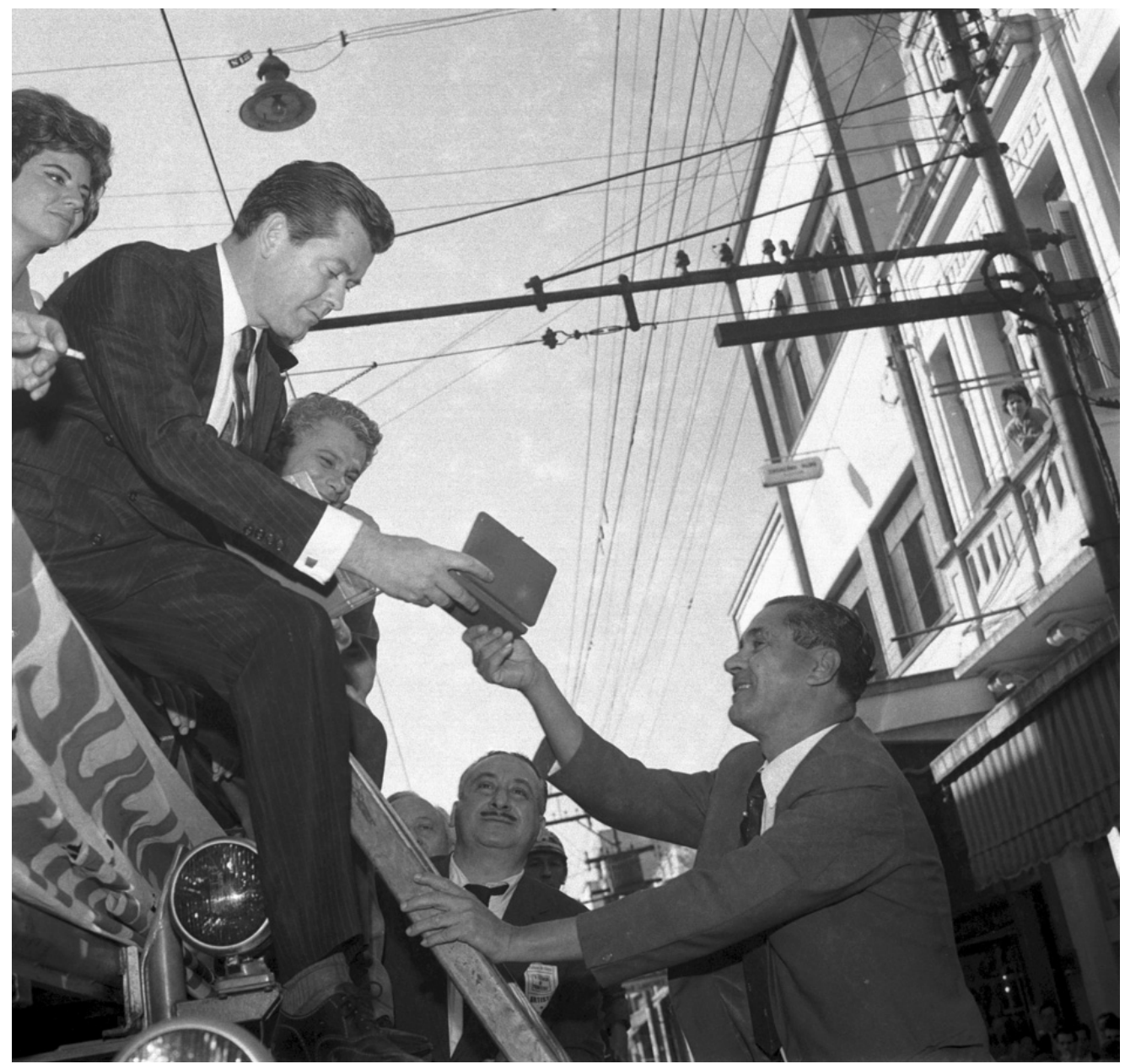

Elenco do filme "O Pagador de Promessas" desfilando pelo Centro de Santos em cima de um caminhão do Agrupamento do Corpo de Bombeiros, em 04 de julho de 1962.

Na imagem, o veículo está parado na Rua João Pessoa, em frente ao prédio do jornal A Tribuna. Pode-se ver, no alto do caminhão, no canto esquerdo, a atriz Glória Menezes, o diretor Anselmo Duarte no centro e, à sua direita, o ator Geraldo Del Rey. O jornalista Olao Rodrigues, abaixo, de perfil, no ato da entrega a Anselmo Duarte de um cartão de prata - uma homenagem do jornal A Tribuna:

A Tribuna, por seus dirigentes e redatores, homenageou os cineastas laureados com a Palma de Ouro no Festival Internacional de Cannes, entregando-Ihes cartão de prata com expressiva legenda [...] Logo depois, houve o ato público de homenagem da Municipalidade aos consagrados homens do cinema nacional, em plena Praça Mauá. ${ }^{297}$

${ }^{297}$ A Tribuna homenageia Anselmo Duarte. A Tribuna, Santos, 05 de julho de 1962, p.01. 
Ao rever as fotografias, Herrera lembra da quantidade de pessoas que esperavam os atores com máquinas fotográficas e caderninhos para pedir autógrafo.

Foi um grande acontecimento na época, porque nunca um filme brasileiro tinha ganhado tantos prêmios lá fora. As pessoas estavam orgulhosas e queriam demonstrar isso [...] Eu não peguei nenhum autógrafo porque não quis. Eu nunca pedi autógrafo de ninguém, não gostava dessas coisas. Nós jornalistas podíamos pedir e tínhamos facilidade para isso, e muitos pediam. Mas, eu nunca tive essa vontade. ${ }^{298}$

O "Pagador de Promessas" foi o primeiro e até agora o único filme brasileiro a ser premiado com a Palma de Ouro no Festival de Cannes.

${ }^{298}$ Depoimento do fotógrafo. 05/02/2007. 


\subsection{5 - CACILDA BECKER}

Uma das atrizes mais brilhantes que o Brasil produziu, Cacilda Becker Yáconis encenou 68 peças ao longo de quase 30 anos de carreira. Embora tenha nascido em Pirassununga, interior paulista, veio aos dez anos com a família para Santos, onde foi descoberta e iniciou a sua carreira. Mesmo depois que se mudou para São Paulo continuou a manter contato com a Cidade, onde se apresentou diversas vezes. $^{299}$

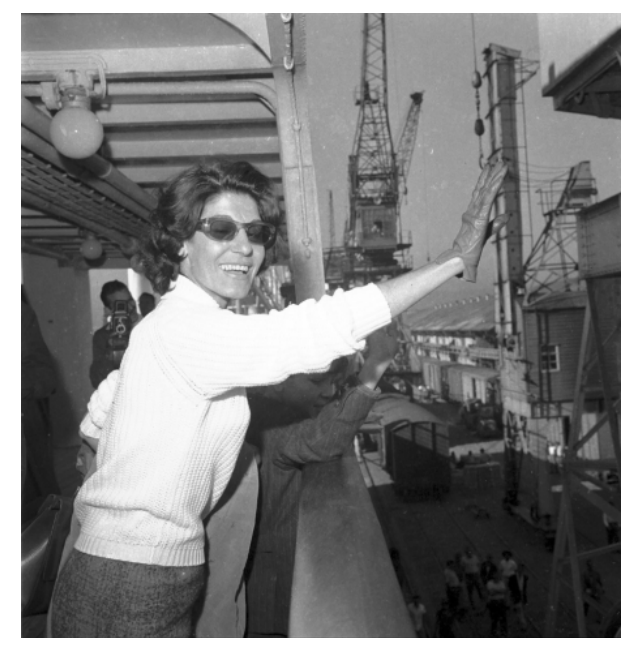

Cacilda Becker se despedindo no Porto de Santos, antes de embarcar para a Europa, onde iria se apresentar. 19 de abril de 1950. Gelatina/prata, $6 \times 6 \mathrm{~cm}$. Acervo particular José Herrera.

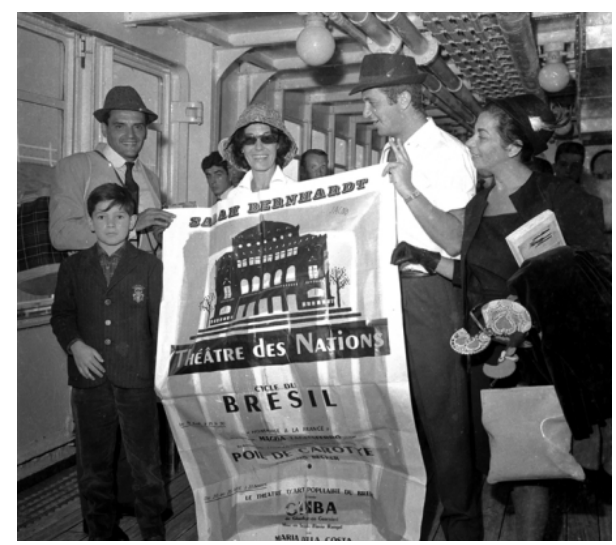

Cacilda Becker com o cartaz que apresentava a peça que iria estrelar na Europa. Porto de Santos, 19 de abril de 1950. Gelatina/prata, $6 \times 6 \mathrm{~cm}$. Acervo particular José Herrera.

${ }^{299}$ Cacilda Becker e Paulo Autran dão nomes a espaços do Coliseu, A Tribuna. Santos, 16 de outubro de 2007, p.D4. 


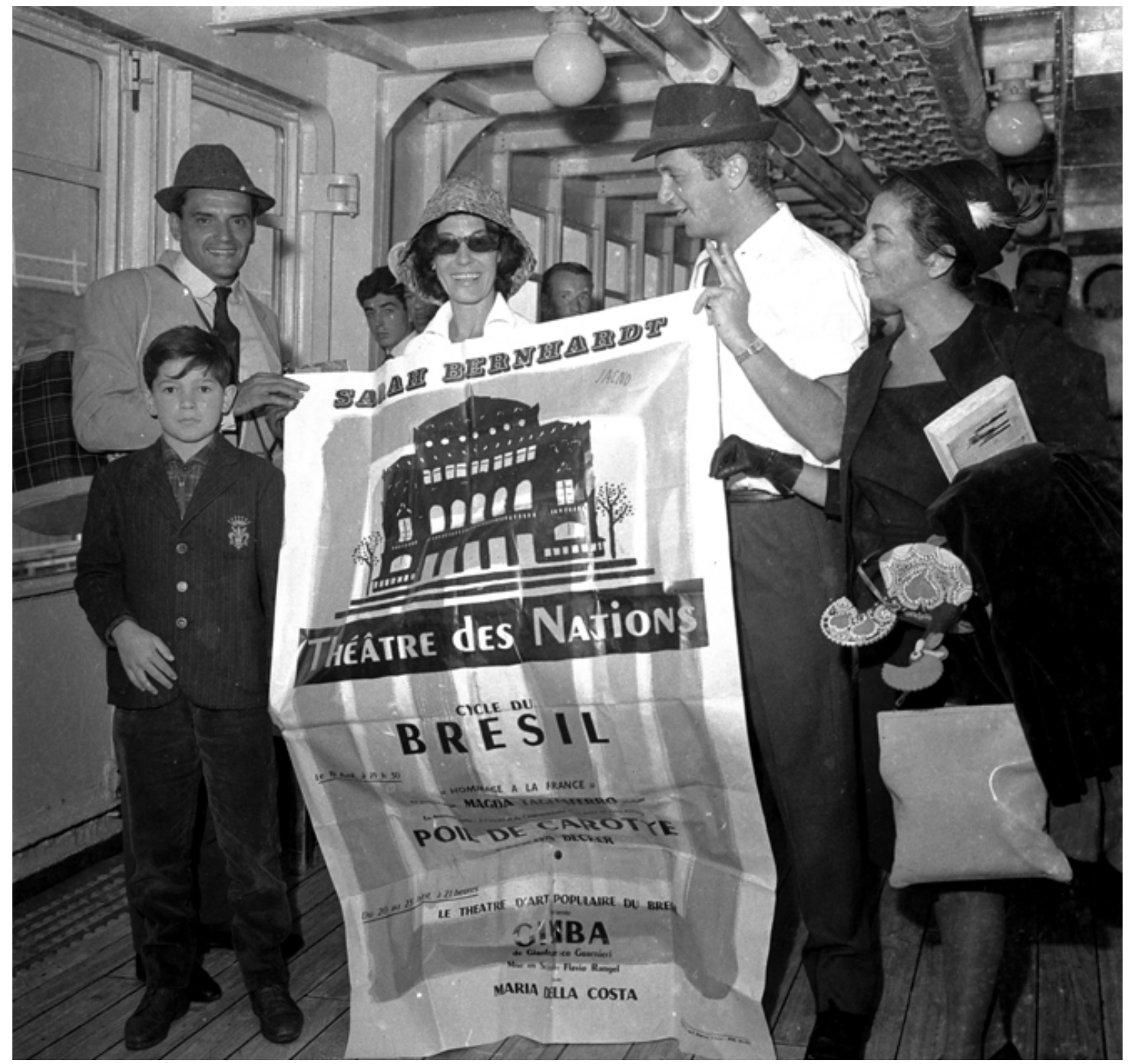

A atriz Cacilda Becker dentro de um navio de passageiros, no Porto de Santos, em 19 de abril de 1950.

A imagem mostra Cacilda Becker já dentro do navio de passageiros, no Porto de Santos, de onde embarcou para Europa com o objetivo de se apresentar no festival Théàtre des Nations. A atriz posa para a foto atrás do cartaz do espetáculo, chamado Cycle Du Bresil, que é segurado por dois homens e uma mulher, provavelmente fãs. À esquerda, um menino também integra a foto. Nota-se o estilo despojado de Cacilda, de óculos escuros e chapéu. Os outros quatro vestem trajes tipo passeio. Os homens usam chapéu, calça social, camisa e gravata, e um deles ainda veste um casaco. A mulher, que também está de chapéu, usa luvas, vestido e casacão. O menino veste calça, camisa, casaco de botão e calça sapatos. 
José Herrera recorda do tempo em que era amigo da atriz:

Dancei muito com a Cacilda Becker nos bailes da vida; eu a conheci no comecinho da carreira, quando ela era dançarina [...] Ela era muito amiga da Rosinha Mastrângelo, que escrevia a parte social do jornal O Diário. Éramos todos amiguinhos [...] Na verdade, eu conheci a sua família inteira, inclusive a irmã, Cleide Yáconis, que também virou atriz e é viva até hoje $[\ldots]^{300}$

Cacilda Becker Yáconis, nascida em 6 de abril de 1921, foi um mito do teatro brasileiro. Teve rápida passagem pela famosa companhia Os Comediantes, de Ziembinski. Depois, foi para o TBC ${ }^{301}$, onde ficou dez anos. Saiu em 1958 para montar a própria companhia, que dirigiu até o final da vida. ${ }^{302}$

O jornal Diário de Santos publicou uma breve retrospectiva da história da atriz desde a sua mudança para Santos:

Aos dez anos, mudou-se para Santos, passando a estudar na Escola José Bonifácio. Em 1941, foi indicada pelo escritor santista Miroel Silveira, para substituir uma atriz na montagem amadora da peça 3.200 Metros de Altitude, no Rio de Janeiro. Sem nunca ter participado de um espetáculo teatral, Cacilda, que na época era bailarina, não atriz, fez seu papel muito bem, projetando-se rumo ao estrelato. Durante o ano de 1968, deixou de lado os palcos e passou a presidir a Comissão Estadual de Teatro, indo às manifestações contra a censura organizada pela classe teatral. Morreu em 1969, aos 48 anos, de um aneurisma cerebral quando encenava Esperando Godot, de Beckett, ao lado do marido Walmor Chagas. ${ }^{303}$

Em 16 de outubro de 2007, a Prefeitura de Santos, em homenagem à atriz, publicou o decreto 4.924, que denominou "Cacilda Becker Yáconis" a Sala de Espetáculos situada no Teatro Coliseu.

\footnotetext{
${ }^{300}$ Depoimento do fotógrafo. 26/02/2007.

301 Teatro Brasileiro de Comédia.

302 Paulo Autran e Cacilda Becker terão nomes eternizados no Coliseu, Diário Oficial de Santos. 17 de outubro de 2007, p.20.

${ }^{303}$ Paulo Autran e Cacilda Becker terão nomes eternizados no Coliseu, Diário Oficial de Santos. 17 de outubro de 2007, p.20.
} 


\subsection{6 - AQUÁRIO MUNICIPAL DE SANTOS}

Lugar de lazer, cultura e pesquisa, o Aquário Municipal de Santos, localizado na Ponta da Praia, abriga centenas de espécies da fauna aquática e destaca-se atualmente como a atração turística mais visitada da Cidade e a segunda do Estado de São Paulo. ${ }^{304}$ Primeiro aquário público construído no Brasil, foi inaugurado a 02 de julho de 1945 com a presença do então presidente Getúlio Vargas. ${ }^{305}$

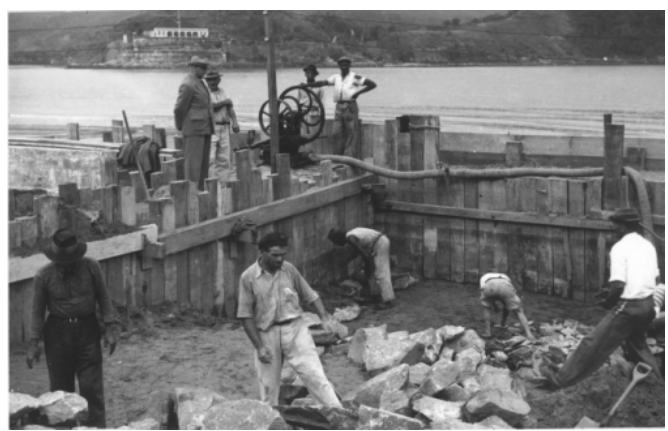

Construção do Aquário de Santos. Inspeção feita pelo prefeito Antonio Gomide, de terno e chapéu ao fundo. 1944. Gelatina/prata, 6×9 cm. Acervo FAMS.

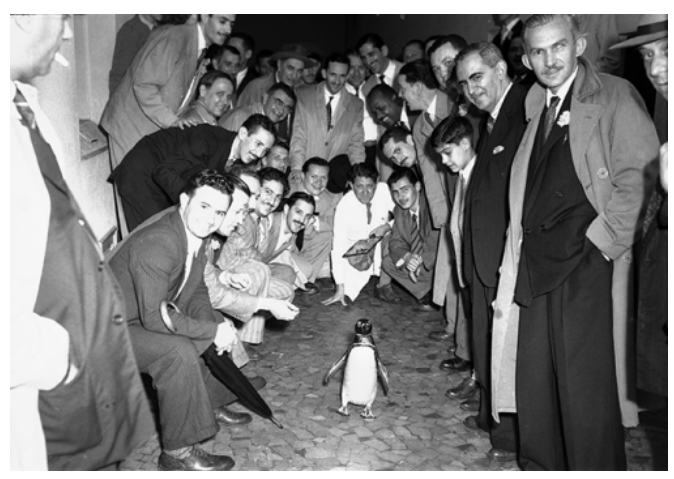

Intervenção para ampliação do Aquário. Agosto de 2004, suporte digital. Acervo Secretaria de Comunicação Socialde Santos.

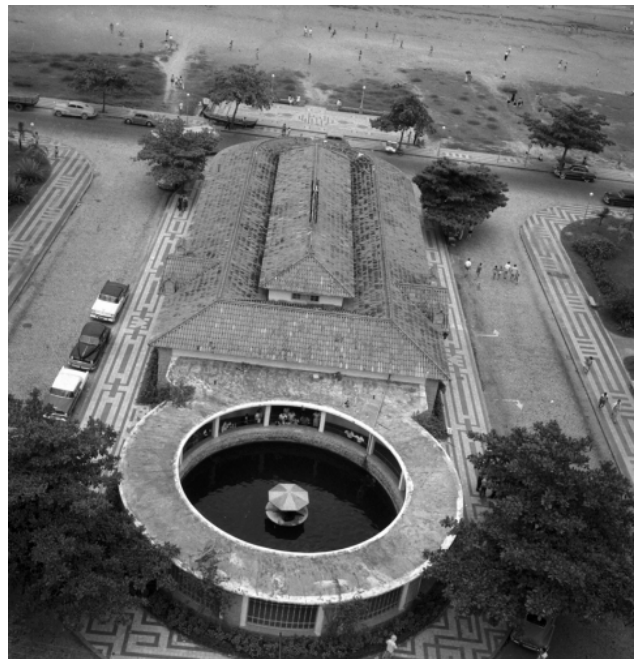

Aquário de Santos visto de cima. 1945. Gelatina/prata, $6 \times 6 \mathrm{~cm}$. Acervo FAMS

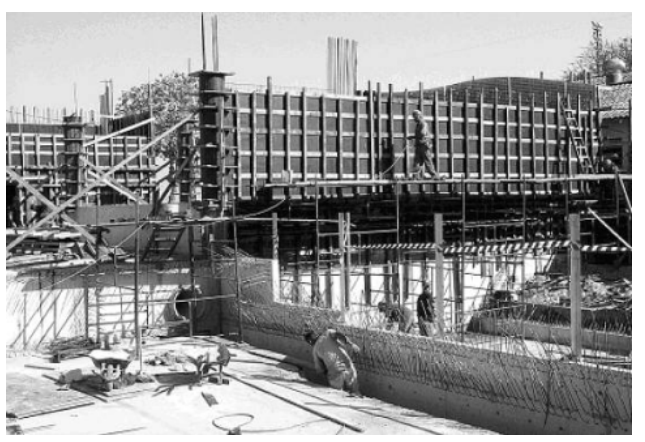

legação de jornalistas que vieram de várias ades para confecer o Aquário Municipal. Na zgem, todos posam com um pingüim, uma das ncipais atrações do parque. Santos, julho de 15, Gelatina/prata, $6 \times 9 \mathrm{~cm}$. Acervo $\mathcal{F A M S}$
Jade!, A Tribuna, Santos, 27 de janeiro de 2006, p. A3. Icial na vida de Santos, No Aquário Municipal. A Tribuna, Santos, 03 de 


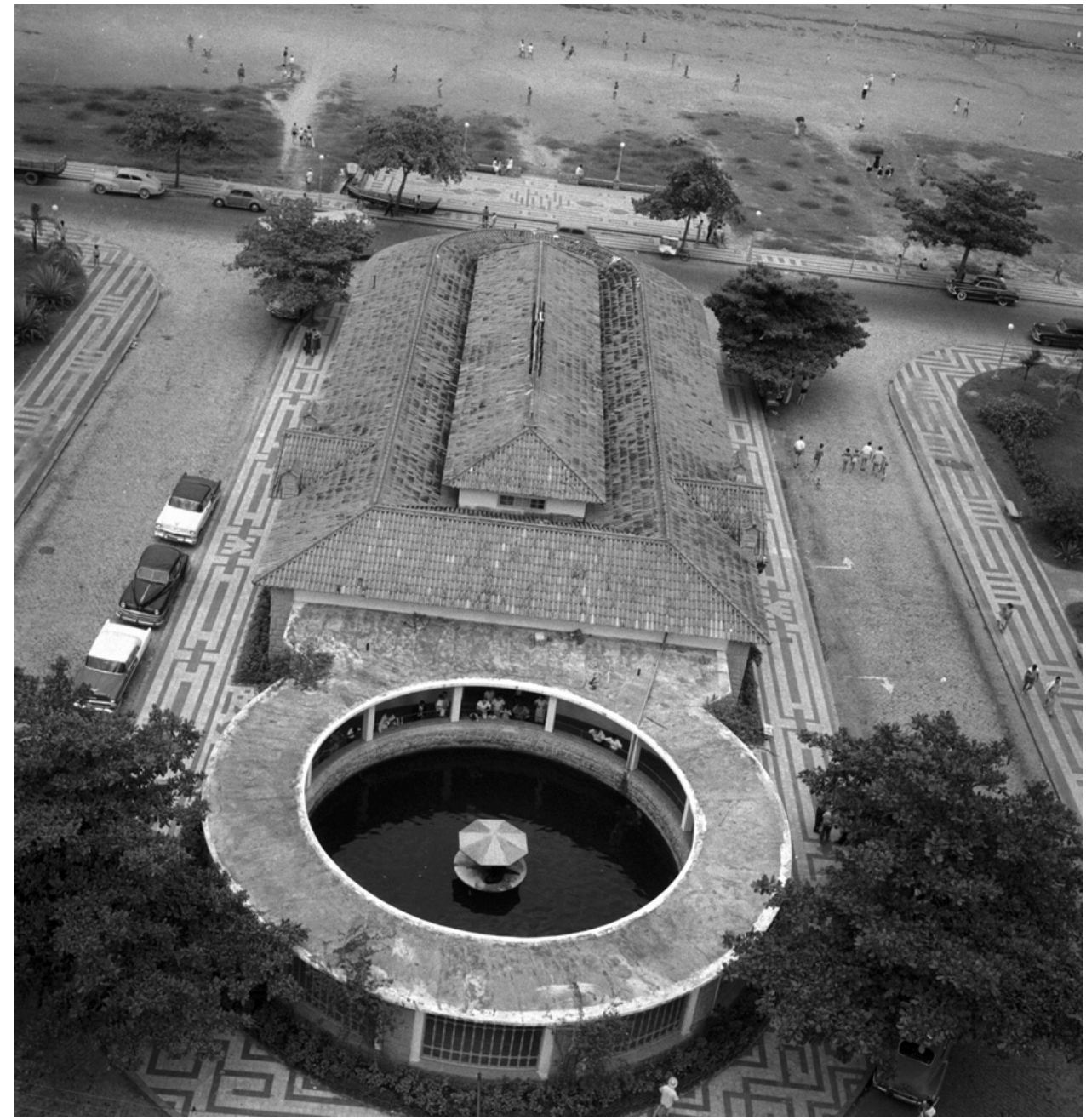

Aquário de Santos visto de cima, logo após a inauguração, em 1945.

Ao fundo vê-se a orla da praia. As duas ruas ao lado não existem mais. A via da esquerda, a antiga Alameda Luiz Carlos Durante, foi fechada em 2005, para a realização de obras de ampliação do Aquário. A rua da direita foi fechada muito antes, no início da década de 1950, cedendo espaço para a ampliação do jardim e construção de um boulevard em frente ao parque. Percebemos também que as calçadas são de ladrilho hidráulico.

A parte redonda da construção tinha o miolo aberto, ao ar livre, e abrigou, entre 1970 e 1995, o leão-marinho Macaé, considerado a principal atração do lugar. Depois da morte do animal, o espaço passou a ser ocupado pelo lobo-marinho Macaezinho, até 2004, quando tiveram início as obras de ampliação do parque. 
Hoje, o círculo está fechado e se transformou num Tanque Oceânico, um dos maiores recintos do novo Aquário. As árvores que aparecem na imagem são os chapéus-de-sol, característicos da Cidade.

Herrera lembra de todo o processo de construção do ponto turístico e da expectativa em torno de sua inauguração:

Estive lá várias vezes para fazer fotos, durante todas as fases da construção. Até o lançamento da pedra fundamental eu fotografei... O Antonio Gomide ${ }^{306}$ fazia vistorias na obra de vez em quando e eu precisava registrar. Ele era muito sério e não gostava de conversa... Perto da inauguração, tive que produzir várias imagens. Toda a Cidade esperava ansiosa a abertura do Aquário... Fez muito sucesso... Aliás, faz sucesso até hoje. ${ }^{307}$

E relembra da cobertura da imprensa no dia:

Jornalistas de várias cidades foram convidados para a inauguração do Aquário porque aquilo era uma novidade no Brasil inteiro. Veio muita gente da imprensa e todo mundo se encantava, principalmente com os pingüins. [...] Tirei uma foto da delegação de jornalistas convidados em volta de um pingüim... E parece que 0 bicho percebeu que era a celebridade e também posou pra foto.

Inicialmente, o Aquário santista ocupava uma área de $1 \mathrm{mil}^{2}$ e tinha 36 tanques. Conforme o Diário Oficial de Santos, após obras de ampliação e modernização, o equipamento foi reinaugurado em 26 de janeiro de 2006 com o triplo do tamanho e novas atrações. O novo complexo é todo climatizado, recebeu trabalho de cenografia que reproduz os 'habitats' originais dos animais e é adaptado para pessoas portadoras de deficiência. ${ }^{308}$

\footnotetext{
${ }_{306}^{306}$ Prefeito de Santos na época em que o Aquário estava sendo contruído.

307 Depoimento do fotógrafo. 31/05/2006.

${ }^{308}$ Novo Aquário com espaço triplicado será entregue nesta quinta-feira, Diário Oficial de Santos, 25 de janeiro de 2006, p.3.
} 


\subsection{7 - NOSSA SENHORA DO MONTE SERRAT - PADROEIRA DE SANTOS}

A imagem atual de Nossa Senhora do Monte Serrat, de barro cozido e $40 \mathrm{~cm}$ de altura, foi feita entre 1652 e 1655 pelo escultor beneditino frei Agostinho de Jesus. A capela foi erguida entre 1599 e 1611 no alto do morro, cuja subida pode ser feita por meio de bondes funiculares ou pelo Caminho Monsenhor Moreira, com 415 degraus e onde há 14 nichos que representam a Via Crucis feitos em granito e bronze, inaugurados entre 1939 e $1941 .^{309} \mathrm{O}$ dia da santa é comemorado em 8 de setembro.

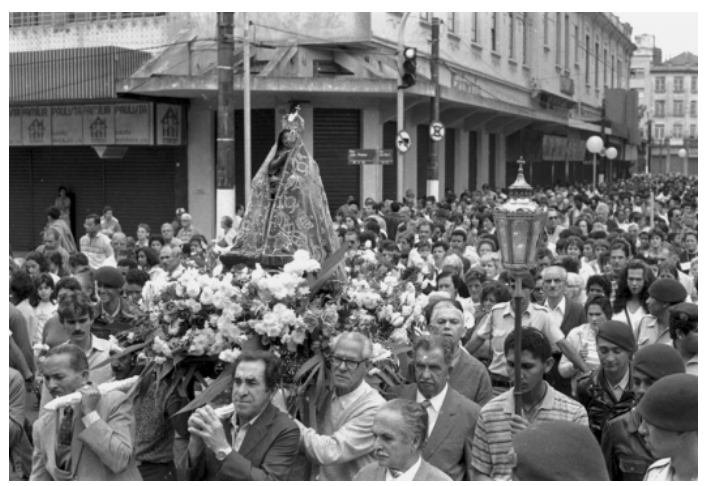

Procissão de Nossa Senhora de Monte Serrat Santos, década de 1950. Gelatina/prata, $6 \times 6 \mathrm{~cm}$. Acervo José Herrera.

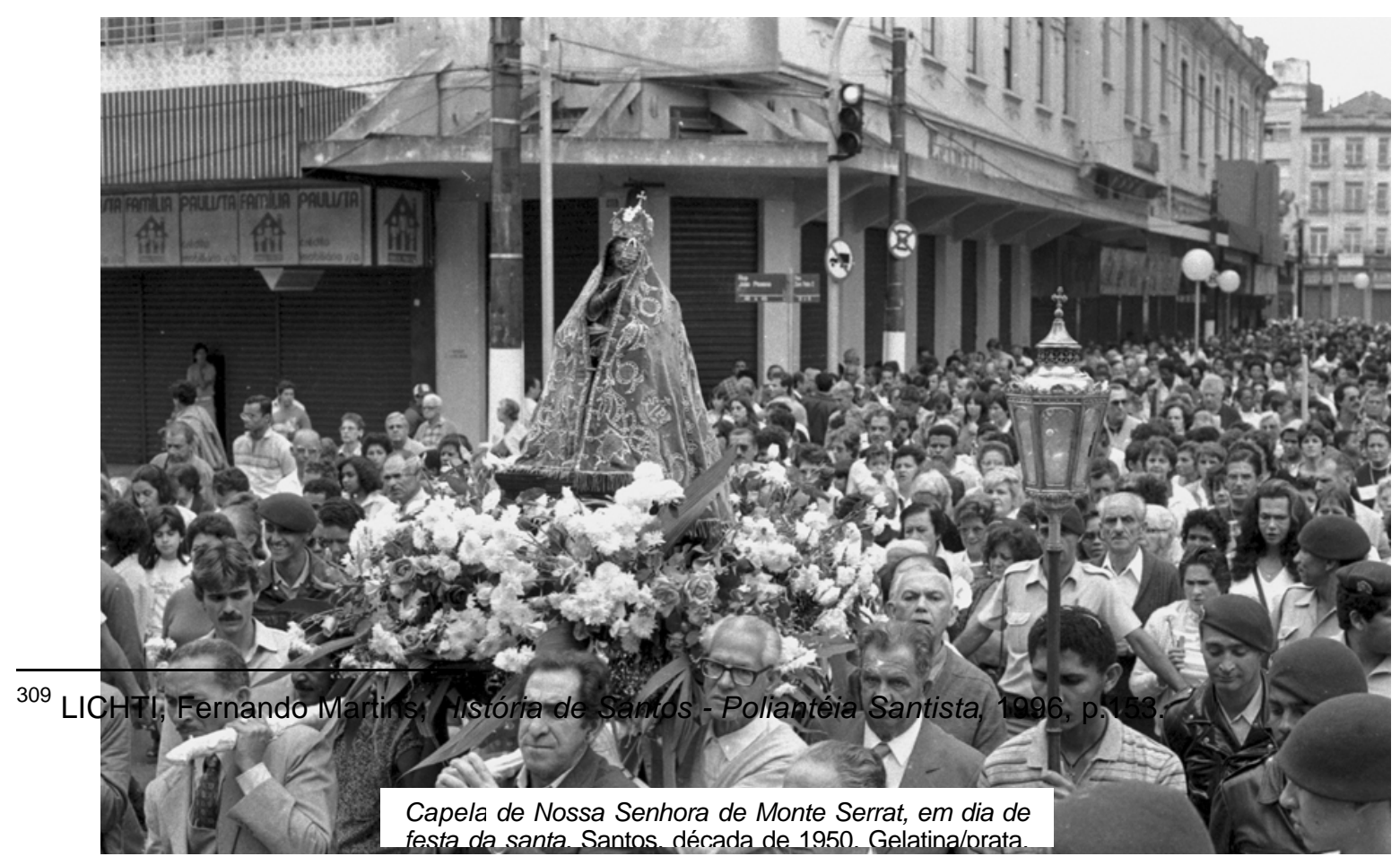


Procissão de Nossa Senhora de Monte Serrat, padroeira da cidade de Santos, realizada no dia 08 de setembro, na década de 1950.

A foto mostra a imagem de Nossa Senhora do Monte Serrat sendo carregada e acompanhada por milhares de fiéis, que saíam da Praça Mauá, entravam na Rua Dom Pedro II e que, nesse momento, atravessam a Rua João Pessoa em direção ao Monte Serrat. Pela localização do semáforo, à esquerda, percebe-se que a multidão segue na contramão. Todo dia 8 de setembro, dia da padroeira, a imagem é levada à capela localizada no alto do Monte Serrat, aja subida é realizada, geralmente, pela escadaria, como afirma José Herrera:

A maioria sobe a pé para demonstrar a fé na santa, para pagar promessas, para fazer um sacrifício... Tem gente que sobe até de joelhos. E tem o fato do bonde ser pago também, né? Isso também dificulta. [...] No dia da santa, o Monte Serrat fica lotado, vem até gente de outras cidades. É um evento muito bonito, tem muita gente se emocionando. ${ }^{310}$

${ }^{310}$ Depoimento do fotógrafo. 11/11/2006. 
Segundo o jornal $A$ Tribuna, a procissão é uma das principais tradições dos santistas e obedece os ritos primitivos das comemorações da Espanha, que aconteciam no célebre mosteiro de Monte Serrate, com romarias, ofertas de velas e solenidades. ${ }^{311}$

Inúmeros são os milagres atribuídos a Nossa Senhora do Monte Serrat, entre eles o famoso desmoronamento do morro, em 1615, sobre os corsários que saqueavam e aterrorizavam a Vila de Santos. Desde essa época, a santa é festejada com grande devoção e, no século XIX, as comemorações em sua homenagem duravam três dias. $\mathrm{O}$ sentimento e culto à imagem tornaram-se tão fortes que, em 1955, Nossa Senhora do Monte Serrat foi proclamada a padroeira da Cidade de Santos. ${ }^{312}$

\footnotetext{
${ }^{311}$ Recanto onde vivem a fé e a tradição de séculos. A Tribuna, Santos, 31 de maio de 1953, p.24.

${ }^{312}$ LICHTI, Fernando Martins, História de Santos - Poliantéia Santista, 1996, p.153.
} 


\subsection{Carnaval}

O Carnaval Santista, nas décadas de 1960 e 1970, era considerado o melhor do Estado de São Paulo, um dos mais destacados do Brasil e estava entre os primeiros do continente. Durante toda a sua história, o Carnaval atravessou momentos diferentes e teve fases bem destacadas: corsos, ranchos e choros, blocos e escolas de samba, bailes de salão, corte carnavalesca, concurso de fantasias, o famoso 'Banho da Dorotéia'.

Como fotógrafo oficial da Secretaria de Turismo, Cultura e Esportes durante décadas, José Herrera acompanhou o Carnaval santista por anos. Em seu acervo, mais de dois mil negativos são da festa momística.

Sempre assiti aos desfiles e entrava nos bailes, mas nunca participei da folia, de nada, só fotografava [...] Não gosto, nunca gostei. Prefiro bolero [...] E olha que antigamente o Carnaval era organizado, não era essa bagunça e esse exagero de hoje. ${ }^{314}$

Em 2000, o carnaval de rua, já bastante decaído, foi proibido na Cidade por ter se transformado numa festa onde predominavam a bagunça e muitas brigas. Os bailes nos clubes permaneceram acontecendo, mas eram poucas as associações que os promoviam. Em 2001, a Prefeitura criou o Carnabonde, que acontece até hoje no sábado anterior ao Carnaval e reúne multidões na Praça Mauá, no Centro. Em 2006, os desfiles de escolas de samba voltaram a acontecer. Desta vez, no terreno conhecido como Estradão, na Zona Noroeste da Cidade. ${ }^{315}$

\footnotetext{
313 JúNIOR, Bandeira, História do Carnaval Santista, 1974, p.94 et seq.

314 Depoimento do fotógrafo, em 22/11/2005,

${ }^{315}$ De volta à folia: Santos retoma os desfiles. Perspectiva, Santos, fevereiro de 2006, p.5.
} 


\subsection{1 - REI MOMO E CORTE CARNAVALESCA}

A corte carnavalesca era presença obrigatória no Carnaval Santista. Tinha como funções presidir todos os desfiles (antes e durante o carnaval), visitar entidades, prestigiar os bailes - dos mais modestos aos mais aristocráticos - e divulgar os festejos do Carnaval Oficial na imprensa. ${ }^{316}$

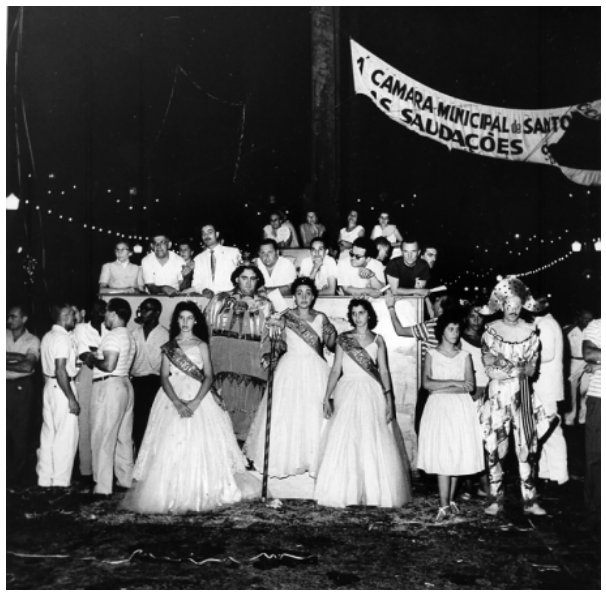

Corte Carnavalesca: rei Momo Waldemar Esteves da Cunha, rainha Claudici dos Santos, princesas e o bobo-da-côrte. No palanque, ao fundo, membros da Associação de Cronistas Carnavalescos de Santos. 1958. Gelatina/prata, $6 \times 6 \mathrm{~cm}$. Acervo particular José Herrera.

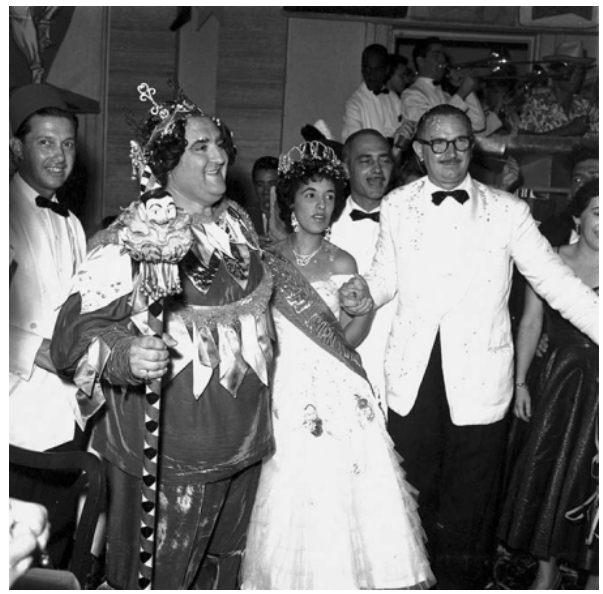

Rei Momo Waldemar Esteves da Cunha e a rainha Irma Milani em baile carnavalesco de salão. 1959. Gelatina/prata, 6x6cm. Acervo particular José Herrera.

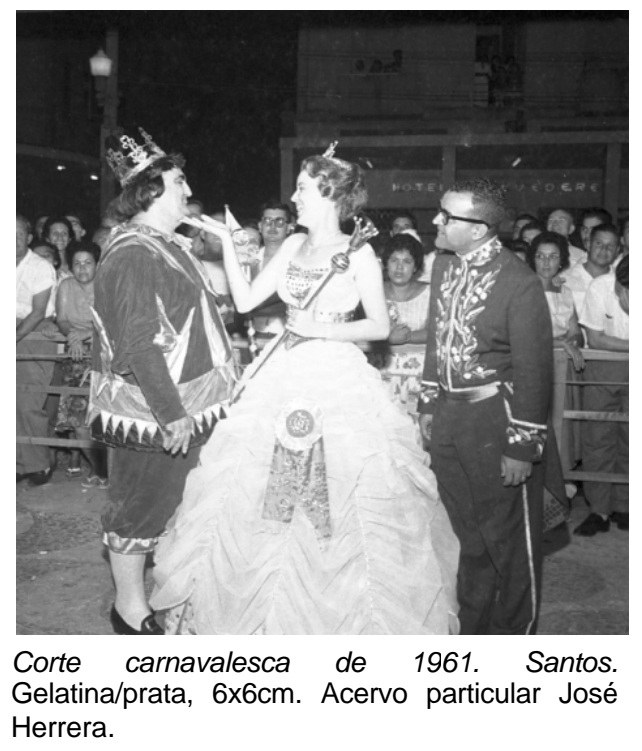

${ }^{316}$ JÚNIOR, Bandeira, História do Carnaval Santista, p.94 e 95. 


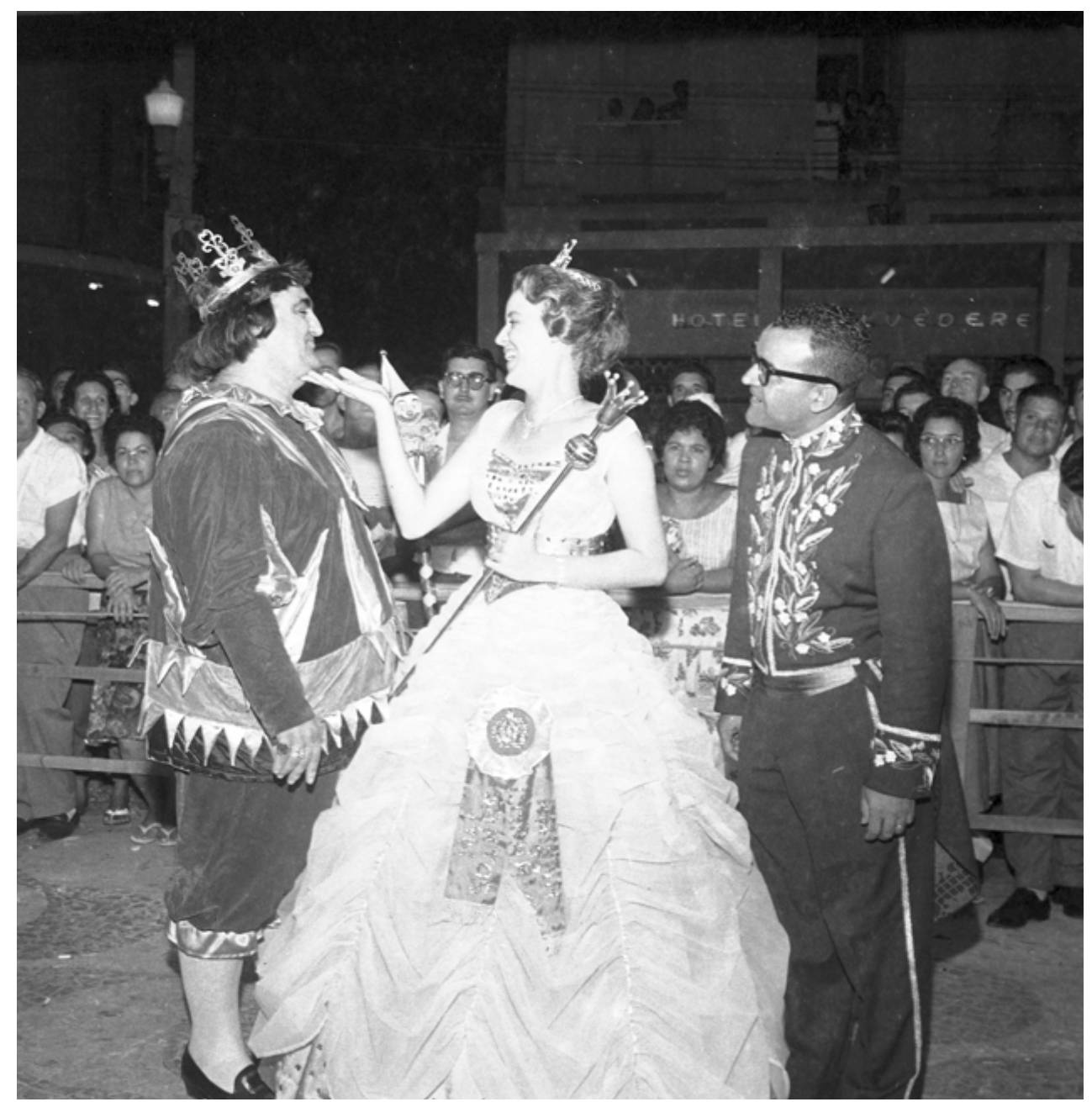

Corte carnavalesca de 1961 durante desfile de rua em Santos.

Na foto vemos o rei momo Waldemar Esteves da Cunha, a rainha Mause Prée e o chanceler Bandeira Júnior. Waldemar ocupou o posto de 1950 a 1991 e entrou para a história do Carnaval, pois o seu reinado foi o mais longo que se tem notícia no Brasil. ${ }^{317} \mathrm{Na}$ época, as roupas dos homens eram feitas de veludo com apliques e bordados. Já a rainha veste um modelo a rigor com corpete bordado com pedrarias. Ela ostenta ainda a coroa, o cetro e a faixa. Nota-se que o público permanecia separado da área do desfile por grades de contenção que substituíram os antigos cordões. Não havia ainda as arquibancadas para assistir aos desfiles.

José Herrera se recorda das diversas formações da corte momística:

${ }^{317}$ Rei Momo de Santos foi o mesmo por 41 anos. A Tribuna, Santos, 26 de fevereiro de 2006, p.A5. 
Primeiro, eram o rei, a rainha e as princesas. Depois, colocaram uma espécie de bobo-da-côrte no lugar das princesas e, por último, criaram um chanceler para acompanhar o rei e a rainha. $\mathrm{Na}$ verdade, a corte rem aproveitava o Carnaval direito, já que tinham que estar em todos os lugares: salões, ruas, desfiles. Era muito cansativo. ${ }^{318}$

${ }^{318}$ Depoimento do fotógrafo. 22/11/2005. 


\subsection{2 - CORSOS}

Enquanto existiram os carros abertos, o corso imperava no Carnaval Santista, acontecendo anto nas pistas da praia como no Centro. Com o surgimento dos automóveis fechados na década de 1940 e com a crise de combustível durante a $2^{\mathrm{a}}$ Guerra Mundial, o corso foi acabando. Em 1964, voltou a ser realizado somente na orla, mas, no ano de 1966, foi extinto por determinação das autoridades policiais por causa de confusões e da paralisação do tráfego. Voltou a ser promovido na orla em 1973, mas não teve êxito. ${ }^{319}$

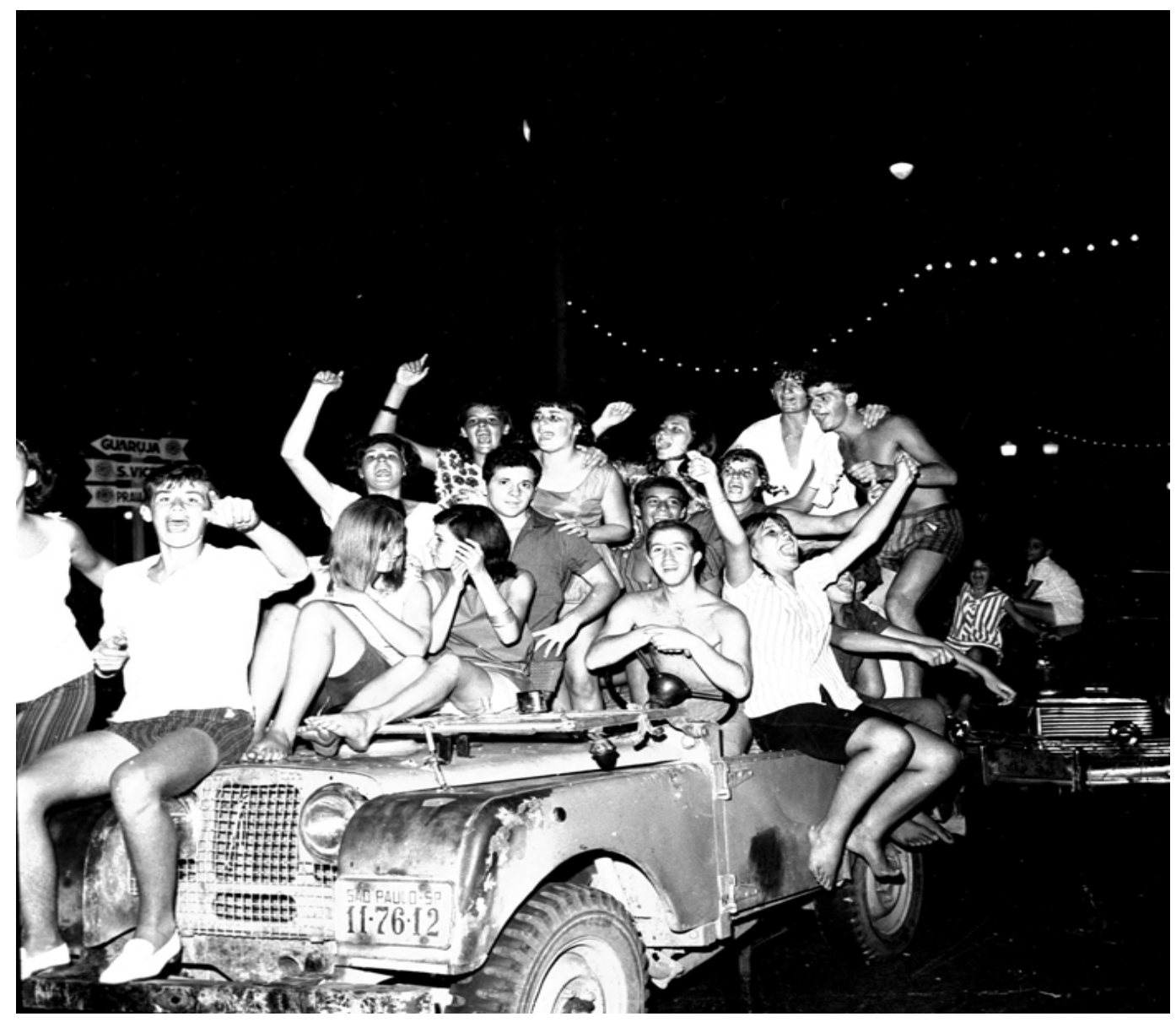

Foliões participando de um corso automobilístico na orla da praia, em 1965.

319 JÚNIOR, Bandeira, História do Carnaval Santista, 1974, p.80 et seq. 
A imagem mostra que os foliões não estão fantasiados. Alguns participantes estão de pé no pára-lamas e outros, sentados na capota e nas portas do jipe Land Rover.

José Herrera lembra da grande quantidade de carros e pessoas que participaram do corso naquela época, principalmente de turistas:

Os corsos atraíam muita gente de fora. Os carros eram todos enfeitados e formavam uma fila enorme na orla [...] Tinham os carros com capota aberta, e os caminhões também participavam levando as pessoas nas carrocerias ... eles iam batucando e jogando confetes e serpentina. Com o passar dos anos, realizavam o corso em qualquer carro conversível e até em jipes, kombis e caminhonetes. 320

Uma nota do jornal A Tribuna, de 03 de março de 1965, confirma a lembrança do fotógrafo:

Ontem não houve corso ao longo das praias. Quer dizer, corso organizado, embora se observassem centenas de carros pelas pistas do Gonzaga ao José Menino. O desfile de blocos, ranchos e escolas de samba impediu o uso da chamada parte nobre das pistas da praia. Na noite de sábado o corso foi até à 1 hora da madrugada, predominando a alegria dos brotos [...] Ontem, no entanto, com pistas livres, o desfile de carros foi simplesmente impressionante. Como o desfile de hoje se realiza no centro da cidade, a pista das praias estará livre para o grande corso de automóveis, que, desse modo, oferece perspectivas assombrosas, tal o elevado número de carros do planalto que se encontra na Baixada. ${ }^{321}$

\footnotetext{
${ }^{320}$ Depoimento do fotógrafo. 22/11/2005.

${ }^{321}$ Corso da brotolândia. A Tribuna. Santos, 03 de março de 1965, p. 20.
} 


\subsection{3 - BLOCOS DE RUA E BAILES DE SALÃO}

Por volta de 1940, desaparecem os conjuntos de rua e o Carnaval santista limita-se aos bailes de salão. Com o aumento do turismo na Cidade, percebe-se a necessidade da reorganização da festa e uma comissão de cidadãos, tendo à frente o jornal O Diário, decide promover os festejos de 1950, organizando batalhas de confete e concursos de blocos. O resultado é tão bom que o governo municipal decide oficializar o Carnaval como atração popular e turística em 1954. A partir daí, os blocos tomam conta das ruas e superam o sucesso dos bailes de salão. $O$ Carnaval santista volta ao seu apogeu. ${ }^{322}$

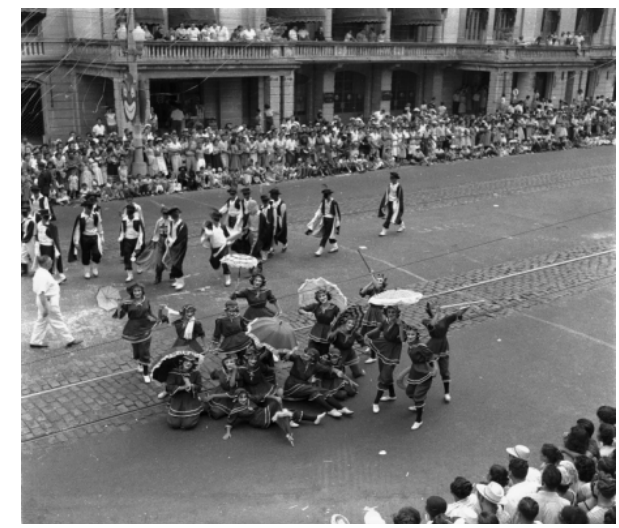

Desfile carnavalesco na Avenida Ana Costa próximo à praia. Santos, Década de 1950. Gelatina/prata, 120mm, 6x6cm. Acervo FAMS.

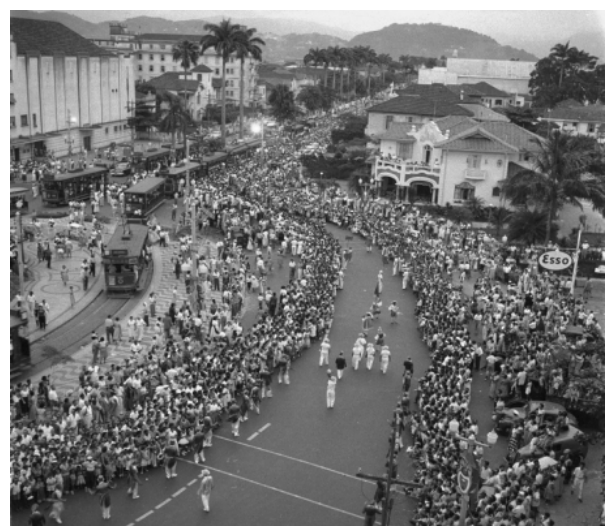

Multidão assitindo ao desfile carnavalesco na Avenida Ana Costa - trecho da Praça Independência Santos. Década de 1950. Gelatina/prata, $120 \mathrm{~mm}, 6 \times 6 \mathrm{~cm}$. Acervo FAMS.

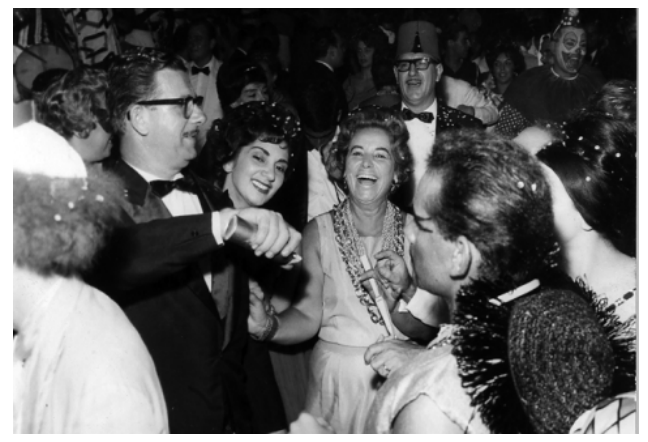

Baile de carnaval de salão. Década de 1960. Santos. Gelatina/prata, $6 \times 6 \mathrm{~cm}$. Acervo FAMS.

322 JúNIOR, Bandeira, História do Carnaval Santista, p.94 e 95. 


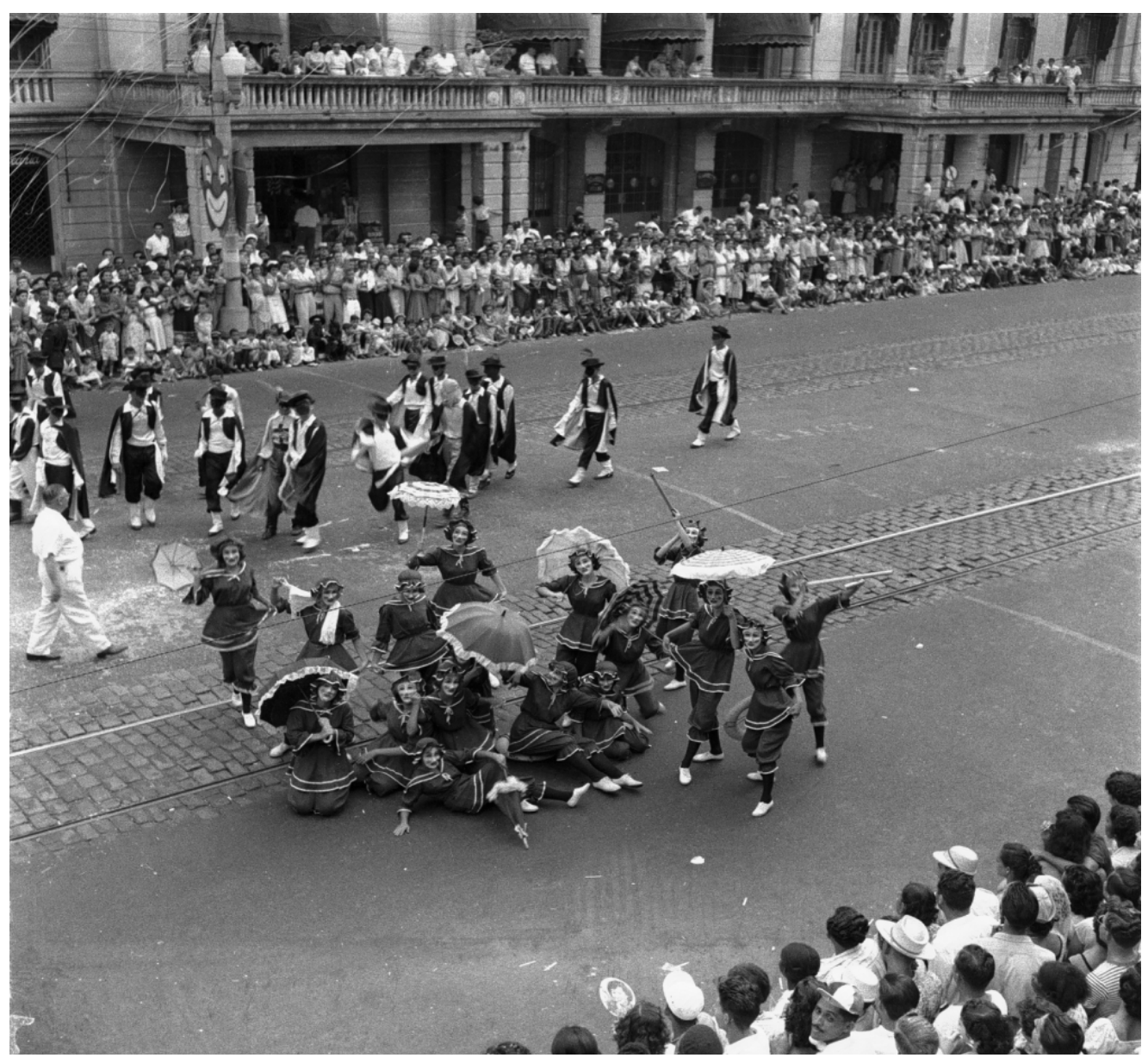

Parte do Bloco das Misses, em primeiro plano, desfilando na Avenida Ana Costa, próximo à orla da praia, na década de 1950.

A imagem mostra os foliões fazendo pose para o público e usando vestidos comportados e sombrinha. Vale ressaltar que as 'misses' são homens vestidos de mulher. Percebe-se a multidão acompanhando os desfiles nas calçadas e nas sacadas do Atlântico Hotel. A Avenida Ana Costa ainda não tinha o canteiro central nesta faixa.

José Herrera sempre trabalhou muito no Carnaval, pois tinha que acompanhar todas as manifestações.

Preferia fotografar o Carnaval de rua porque era mais descontraído, divertido e mais bonito. Os desfiles aconteciam tanto na orla, como no Centro e nos bairros [...] Já nos salões e clubes eu ficava pouco tempo; o trabalho era mais rápido porque eu tinha que visitar vários na mesma noite: Tênis Clube, Atlético Santista, Clube 
XV, Centro Recreativo Miramar, Clube Internacional de Regatas e, claro, o baile do Parque Balneário Hotel. Os salões, normalmente, eram freqüentados por pessoas da alta sociedade. ${ }^{323}$

Nesta época, ainda não existiam as escolas de samba. Os desfiles nas ruas eram dos blocos, que competiam entre si. Os mais conhecidos eram os Chineses do Mercado, Baby do Jardim da Infância, Agora Vai, Cruz de Malta, entre outros. Já nos salões de clubes e hotéis, aconteciam os tradicionais bailes a fantasia ou de máscaras. ${ }^{324}$ 


\subsection{4 - BANHO DA DOROTÉIA}

O Clube de Regatas Saldanha da Gama promoveu pela primeira vez, nos preliminares carnavalescos de 1922, o desfile "Dona Dorotéia, Vamos Furar Aquela Onda?", uma passeata que reunia vários blocos de patuscada, e que chegou a ser a única manifestação de Carnaval externa na orla da praia. Os blocos dorotianos eram integrados apenas por homens, na maioria travestidos de mulher ${ }^{325}$

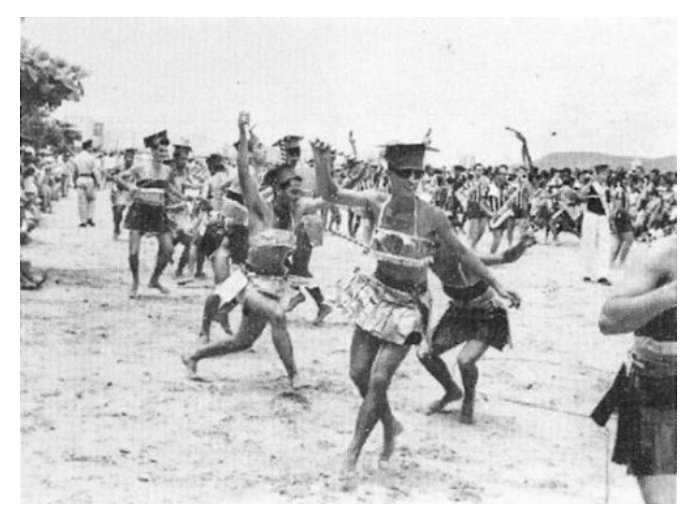

Brincadeira da patuscada "Dona Dorotéia, vamos furar aquela onda?" acontecendo na areia da praia do Gonzaga. 1954. Santos. Gelatina/prata, $6 \times 6 \mathrm{~cm}$. Acervo FAMS.

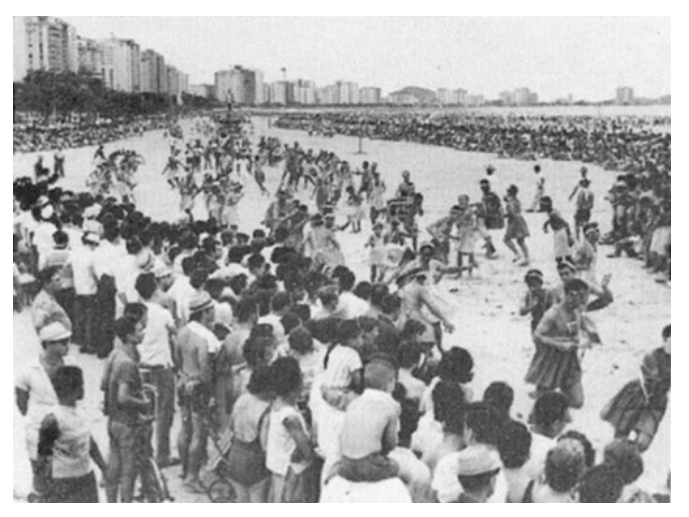

Multidão assistindo a passagem do bloco dorotiano nas areias da praia do Gonzaga. 1954. Santos. Gelatina/prata, 6x6. Acervo FAMS.

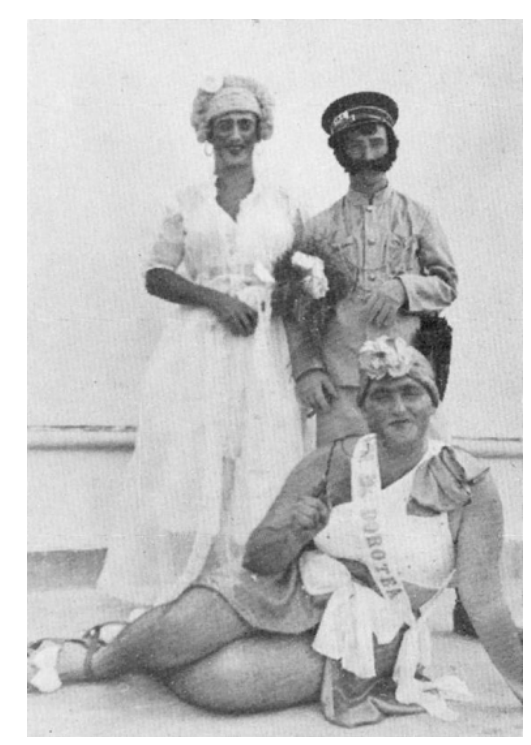

Integrantes do Banho da Dorotéia. Década de 1960. Santos. Gelatina/prata, $6 \times 6 \mathrm{~cm}$. Acervo FAMS.

$\overline{325}$ JÚNIOR, Bandeira, História do Carnaval Santista, 1974, p.75 et seq. 


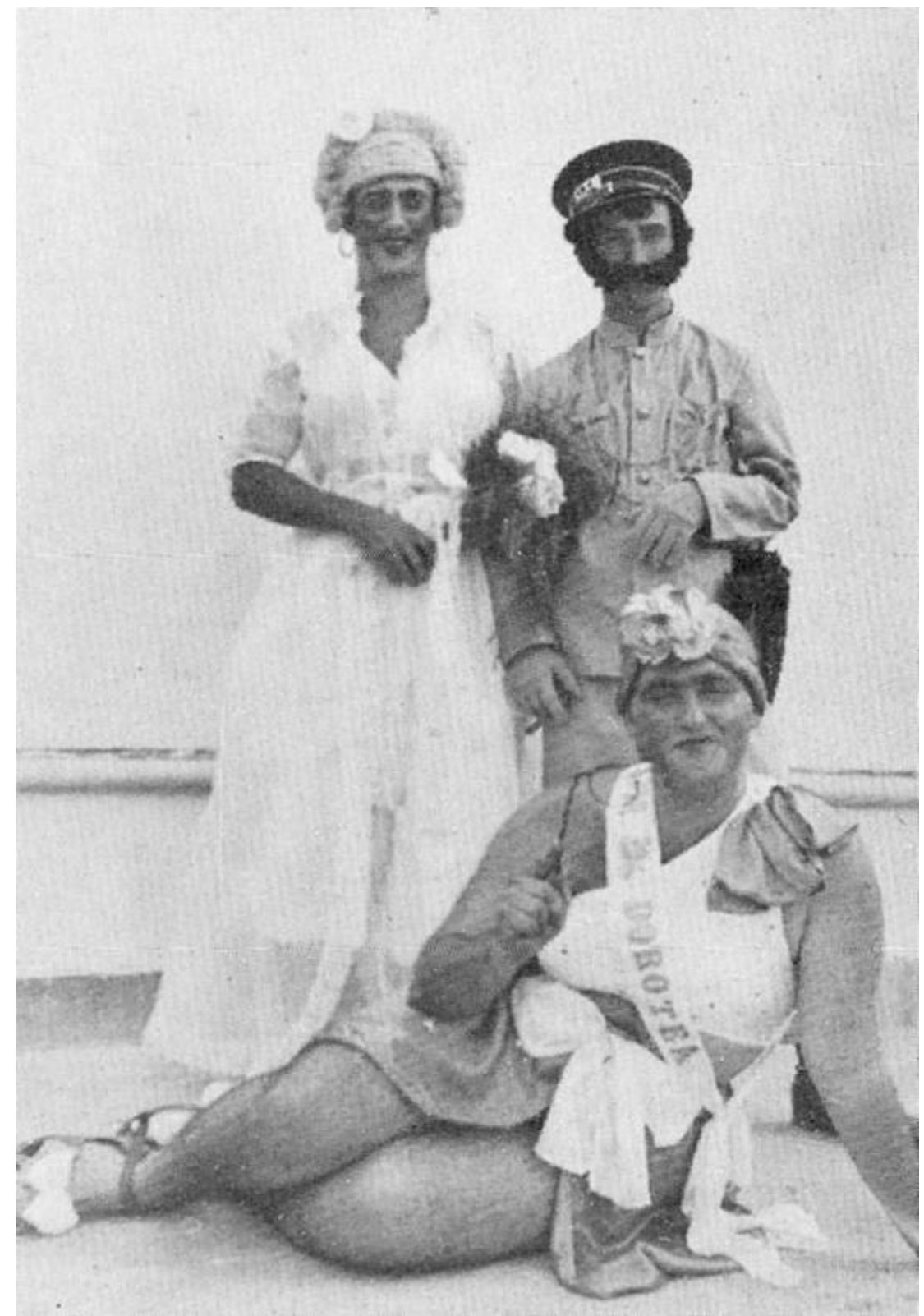

Principais personagens que integravam a patuscada 'Dona Dorotéia, Vamos furar aquela onda?': casal de noivos e a própria Dona Dorotéia.

A imagem mostra que os principais personagens da patuscada 'Dona Dorotéia, Vamos furar aquela onda?' estão posando para a foto. Nota-se que todos são homens. A noiva está de peruca, brincos grandes e maquiagem forte; o noivo, usando barba postiça e roupa de capitão da Marinha; e Waldemar Esteves da Cunha, sentado, fantasiado de Dona Dorotéia, usando uma fantasia de baiana com turbante na cabeça e faixa com a inscrição Dona Dorotea (sem a letra "i”). Percebe- 
se que as fantasias e a maquiagem são exageradas, pois tinham o objetivo de ser cômicas.

José Herrera acredita que a brincadeira fazia mais sucesso do que o próprio Carnaval:

O Banho da Dorotéia acontecia uma semana antes do carnaval e era conhecido em toda a região. Era muito engraçado ver aqueles homens todos fantasiados de mulher [...] Eles normalmente usavam calção de banho por baixo da roupa para poder mergulhar depois do desfile [...] O banho da Dorotéia era mais esperado do que o próprio carnaval, principalmente pela garotada. [...] Não, eu nunca participei. ${ }^{326}$

Até a década de 1940, a patuscada era realizada na Ponta da Praia, culminando com o célebre mergulho da matrona Dona Dorotéia, do noivo e da noiva, do antigo trampolim que existia quase em frente à sede do C.R. Saldanha da Gama. Na década de 1950, o desfile foi transferido para a praia do Gonzaga, mas os foliões voltavam à Ponta da Praia para o tradicional mergulho [...] No ano de 1961, a brincadeira voltou a acontecer na Ponta da Praia, com um palanque oficial montado em frente ao clube. Entre 1962 e 1966, o Banho da Dorotéia foi realizado na praia do Boqueirão e entrou em decadência. De 1967 a 1970, não houve desfile. Em 1971, voltou a acontecer na Ponta da Praia. ${ }^{327}$ Em 1997, foi encerrado de vez por conta da violência.

O fotógrafo lamenta, mas acredita que o encerramento da patuscada foi necessário: No começo, era uma festa de família, que as crianças adoravam.

\footnotetext{
326 Depoimento do fotógrafo. 16/11/2005.

327 A originalidade santista do Dona Dorotéia. Diário Oficial de Santos, fevereiro de 1990, caderno especial História do Carnaval Santista, p.2.
} 
Depois, a desordem tomou conta: muita gente brigando, bebendo, causando confusão. Teve que acabar mesmo. ${ }^{328}$

${ }^{328}$ Depoimento do fotógrafo. 16/11/2005. 


\subsection{5 - CARLITOS DE SANTOS}

O "Carlitos de Santos" surgiu no Carnaval de 1948, quando Mário Rodrigues Filho, o Rouxinol, seu intérprete, tinha apenas 14 anos. Por onde ele passava provocava risos e aplausos da platéia que, nos dias de Carnaval, ia às ruas assistir aos desfiles. Os bondes paravam fora dos pontos só para que os passageiros acompanhassem suas estrepolias, seus sapatos trocados, os passos rápidos e a bengala rodopiando no ar.

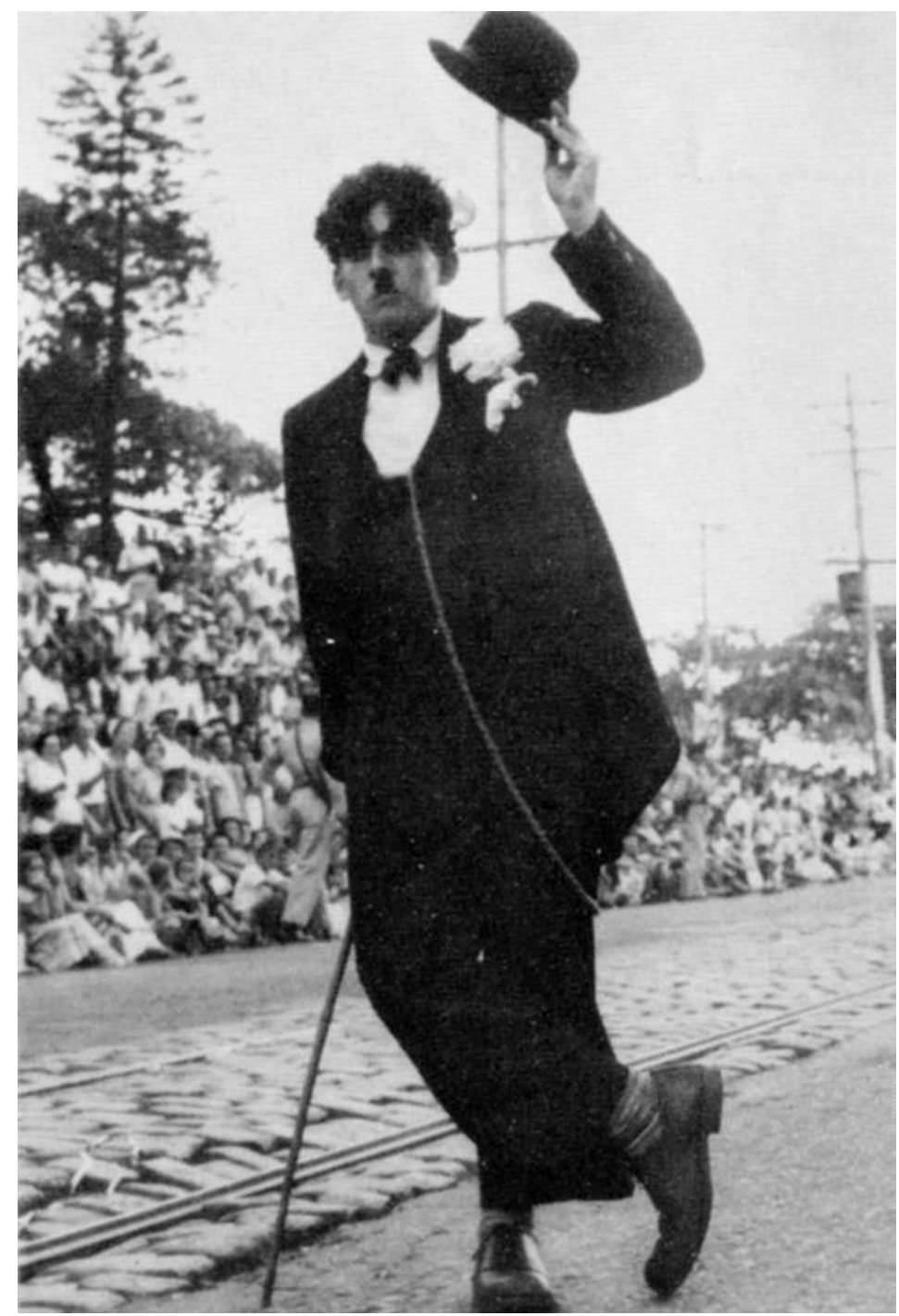

Mário Rodrigues Filho fantasiado de Carlitos, em meados da década de 1950. 
A foto mostra o Carlitos tirando o chapéu para agradecer os aplausos do público durante um desfile em Santos. Nota-se que a rua é de paralelepípedo e que o público que aparece ao fundo está na calçada, sentado no chão, no meio-fio, ou de pé. Mais atrás deve haver uma arquibancada, pois notamos também pessoas sentadas.

Durante 20 anos consecutivos, o Carlitos participou dos carnavais santistas, dançando com uma boneca amarrada aos pés ou puxando um carrinho de lixo sem fundo. Participava como avulso junto aos blocos ou à frente da escola de samba Brasil. Recebeu vários prêmios, como a fantasia mais original e o folião mais divertido, aparecendo em reportagens de jornais e de televisão. ${ }^{329}$

José Herrera diz que o Carlitos ficou famoso e era muito aguardado pelo público.

Depois da Dona Dorotéia e do Rei Momo, ele (o Carlitos) era o personagem mais aguardado do Carnaval [...] Ele aparecia em quase todos os desfiles, andava pelas ruas, mexia com as pessoas [...] Todo mundo ficava procurando e quem achasse já ia gritando: olha o Carlitos lá, olha o Carlitos lá [...] Ele ficou famoso mesmo. ${ }^{330}$

\footnotetext{
${ }^{329}$ A originalidade santista da Dona Dorotéia. Diário Oficial de Santos, fevereiro de 1990, caderno especial História do Carnaval Santista, p.2.

${ }^{330}$ Depoimento do fotógrafo. 16/11/2005.
} 


\subsection{O Porto}

Em 2 de fevereiro de 1892, o navio Nasmith atracava no primeiro trecho de 260 metros de cais construído em Santos, na região do Valongo, registrando o momento histórico em que o modesto atracadouro se tornava o primeiro porto organizado do Brasil. A obra representava a superação de grandes dificuldades técnicas, que durante muitos anos desafiaram a capacidade de realização dos brasileiros e levaram ao insucesso diversas tentativas anteriores de construção do porto, tanto de particulares como da então Província de São Paulo, que havia obtido, desde 1870, autorização para execução das obras. Somente em 1886, um grupo liderado pelos brasileiros Cândido Gafrée e Eduardo Palassin Guinle obteve a concessão para construção e exploração do Porto de Santos. ${ }^{331}$

Hoje, o complexo portuário santista possui 14 quilômetros de cais acostável, 7 milhões e 700 mil metros quadrados de área pelos quais circulam cerca de $40 \%$ do PIB nacional e saltou de 124.734 toneladas movimentadas no seu primeiro ano de vida para 75 milhões de toneladas em 2006. ${ }^{332}$

José Dias Herrera lembra que sempre fotografou o Porto, principalmente entre as décadas de 1950 e 1970, quando trabalhava no jornal A Tribuna e fazia a cobertura para o caderno Porto \& Mar, criado em 1953, pelo jornalista Francisco Azevedo.

Tenho mais de 2 mil negativos só de Porto. Eu ia praticamente todo dia até o cais, mesmo de férias e aos domingos [...] e não era só pra fotografar a mercadorias embarcando ou desembarcando. $\mathrm{O}$ Porto sempre foi muito movimentado e sempre tinha novidades: greve dos estivadores, algum navio incendiando, a chegada dos transatlânticos, os cruzadores... Enfim, o Porto sempre rendeu

\footnotetext{
${ }^{331}$ www.portodesantos.com.br - site oficial da Codesp (Companhia Docas do Estado de São Paulo)

332 Porto: uma história de recordes, Jornal da Orla. Santos, 30 de janeiro de 2005, p.06.
} 
muitas matérias [...] O Porto de Santos é incomparável a qualquer um da América Latina. Não tem ninguém mais preparado que os portuários santistas. O problema do Porto é uma questão política. ${ }^{333}$

${ }^{333}$ Depoimento do fotógrafo. 13/02/2006. 


\subsection{1 - EXPORTAÇÃO DE PRODUTOS DIVERSOS}

Açúcar, café, algodão, banana, laranja, grãos em geral e até tratores. O Porto de Santos sempre foi a porta de saída dos produtos e riquezas brasileiras que conquistaram o mundo.

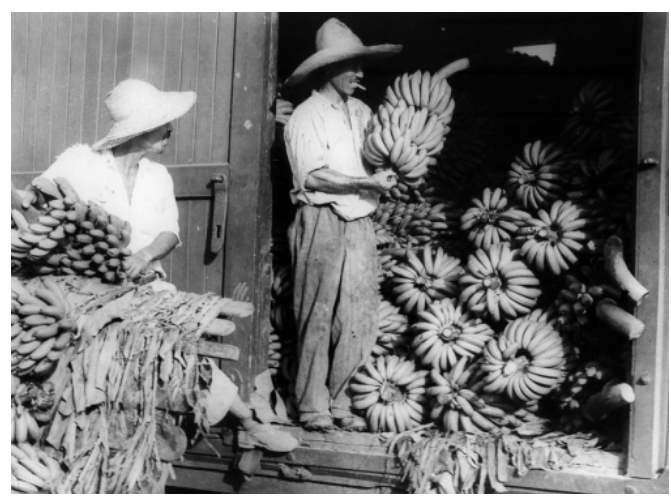

Embarque de bananas em vagões fechados. Meados da década de 1940, Gelatina/prata, 6x9cm. Acervo FAMS.

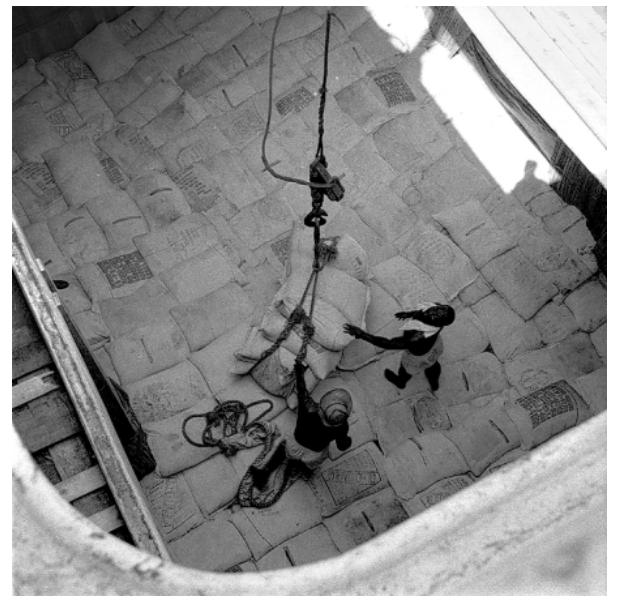

Descarregamento de sacas de café por meio de guindaste para sacaria (cordas). O produto foi direto dos vagões do trem para os porões do navio. Década de 1950, Gelatina/prata, $6 \times 9 \mathrm{~cm}$. Acervo FAMS.

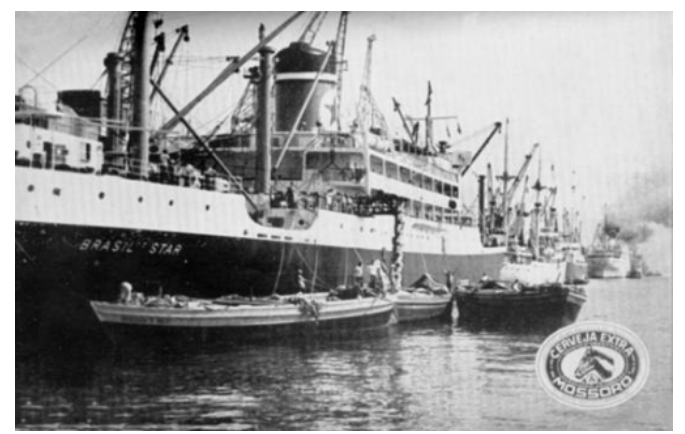

Embarque de bananas para Europa no Porto de Santos. Meados da década de 1950. Reprodução do Guia Santista (Tourist Guide to Santos), de 1956.

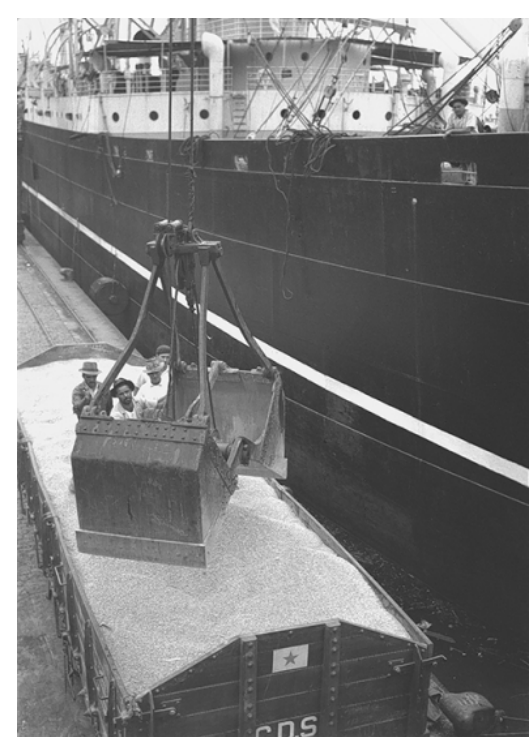

Descarregamento de soja a granel por meio de guindaste com equipamento específico aclopado. O produto foi direto dos vagões do trem para os porões do navio. Década de 1950, Gelatina/prata, $6 \times 9 \mathrm{~cm}$. Acervo FAMS. 


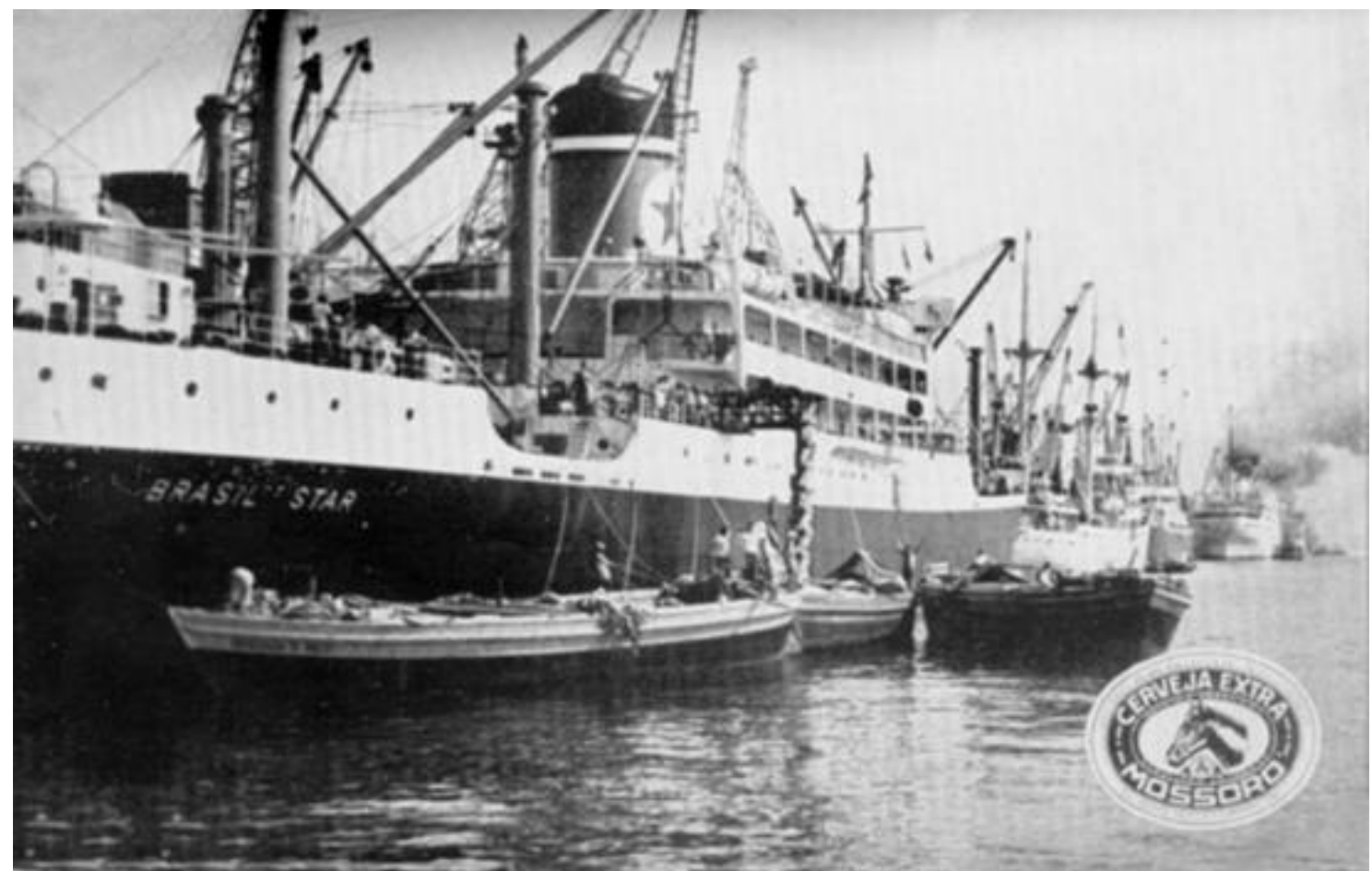

Aspecto do Porto de Santos em meados de década de 1950.

$\mathrm{Na}$ imagem vemos como funcionava um embarque de bananas. As frutas, destinadas ao mercado europeu, eram embarcadas por meio de dalas ${ }^{334}$, a partir de barcaças. O navio que recebeu as bananas foi o Brasil Star. A imagem foi publicada no Guia Santista do ano de 1956 e reproduzida com a logomarca de uma das empresas anunciantes nesse indicador, a antiga Cervejaria Mossoró, sediada em Campinas/SP e que teve fábrica em Santos.

Os vários produtos exportados pelo Porto de Santos foram fotografados por José Herrera, que destaca principalmente grãos e frutas:

Me lembro que o café e o açúcar normalmente saíam ensacados daqui. Os sacos de açúcar eram de $100 \mathrm{~kg} \mathrm{e,} \mathrm{mais} \mathrm{tarde,}$ começaram a aparecer os sacos de $50 \mathrm{~kg}$ [...] Já o trigo e a soja iam soltos nos porões dos navios [...] $E$ as frutas, como tangerina $e$ laranja, eram exportadas em caixas. Hoje, já exportam até em forma de suco, em tambores [...] Me lembro também do ciclo de ouro da banana, que era exportada principalmente para a Europa e países da América do Sul [...] Nessa época, inclusive, havia aqui em Santos

${ }^{334}$ Espécie de esteira transportadora. 
uma famosa indústria de balas e doces à base de bananas chamada A Leoneza. ${ }^{335}$

O auge do "ciclo da banana" foi na metade do século XX, ocorrendo significativo declínio desde então, tanto na industrialização como na exportação. Esse declínio já era sentido na década de 60, como divulgou o jornal $A$ Tribuna, em 1963.

Foram exportados de Santos no mês de julho último, cerca de 695.690 cachos de banana[...] Os índices gerais acusam decréscimo nas exportações, pois de janeiro a julho deste ano foram enviados para países estrangeiros 5.814.628 cachos, enquanto em igual período do ano passado eram remetidos 7.153.767 cachos $[. . .]^{336}$.

José Herrera relembra ainda da disposição e boa vontade dos estivadores em facilitar o seu trabalho:

Os navios eram muito escuros, não dava para fotografar direito. Por isso, eu preferia fazer a foto durante o embarque. [...] Os estivadores me tratavam com muito respeito, se preocupavam em arrumar a mercadoria do jeito que facilitasse a foto e disfarçavam muito bem, fingindo que não estavam nem aí, mas eu sei que eles queriam aparecer na foto. ${ }^{337}$

335 Depoimento do fotógrafo. 13/02/2006.

${ }^{336}$ Bananas: 1 milhão a menos de cachos exportados, A Tribuna. Santos, 11 de agosto de 1963, p.24.

337 Depoimento do fotógrafo. 13/02/2006. 


\subsection{2 - NAVIO RAUL SOARES}

O navio Raul Soares chegou ao Porto santista a 24 de abril de 1964 e, ancorado junto a Ilha Barnabé, foi utilizado, de maio a outubro, como prisão para os acusados de crimes políticos pelas autoridades do regime militar. Palco de torturas físicas e psicológicas, tornourse um dos símbolos da repressão em Santos.

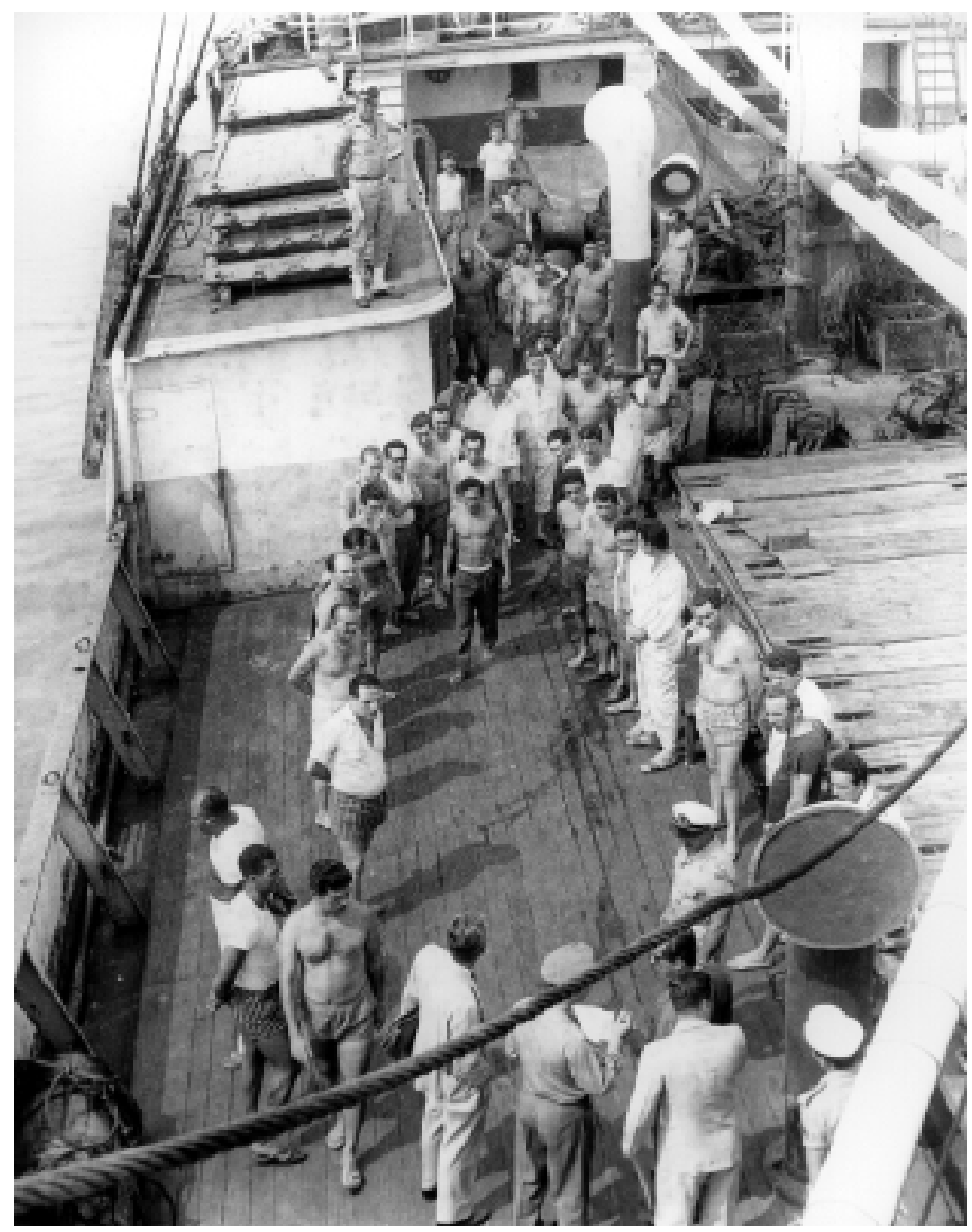

Interior do navio Raul Soares, no Porto de Santos, em 1964.

A imagem mostra o convés do navio-presídio Raul Soares com cerca de 40 presos enfileirados para a visita da imprensa e dos militares. A maioria dos prisioneiros está sem camisa e com os pés descalços. Já os militares, estão 
devidamente uniformizados. Nota-se também o mau estado de conservação da embarcação. José Herrera lembra de quando foi fotografar o interior do navio:

Arrumaram tudo esperando a gente chegar no Raul Soares[...] Os presos estavam no convés para serem fotografados, muitos reclamavam pra gente, mas a gente não podia fazer nada. Fiz as imagens e fui embora... Na época, os jornais só podiam divulgar que os presos eram bem tratados no Raul Soares. ${ }^{338}$

Sob a acusação de subversão, muitas pessoas, entre sindicalistas, médicos, advogados, professores, jornaleiros e trabalhadores portuários, foram presas e torturadas no navio-presídio. Algumas delas morreram, pois não resistiram às punições e atrocidades dos militares. A presença do Raul Soares em Santos era uma forma de manchar o orgulho da cidade que, por tradição, era uma das mais oposicionistas do país, com um povo consciente e sindicalismo de vanguarda.

A jornalista Lídia Maria de Melo, filha de um sindicalista aprisionado no navio Raul Soares, descreve a pressão psicológica a que os presos eram submetidos.

[...]De vez em quando, os próprios policiais lançavam o boato de que um rebocador estava a caminho para transportá-lo (o navio) para alto-mar[...] Às vezes, desligavam a energia elétrica e todos ficavam às escuras. Outras vezes, cortavam o fornecimento de água. Mesmo durante as refeições, os presos permaneciam sob a mira de metralhadoras[...] As doenças, por sinal, eram uma constante no Raul Soares, que não dispunha de uma equipe de saúde[...]. ${ }^{339}$

Antes de ser transformado em prisão, o Raul Soares, antigo transatlântico alemão, adquirido pelo Lloyd Brasileiro em 1925, havia transportado os pracinhas da FEB aos campos de batalha na Europa, para lutar contra as forças do Eixo. Nada

\footnotetext{
338 Depoimento do fotógrafo. 30/09/2005.

339 MELO, Lídia Maria de, Raul Soares, um navio tatuado em nós, 1995, p.92.
} 
mais resta do velho navio. Suas chapas de aço foram desmontadas e viraram sucata. $^{340}$

340 Sindicato dos Empregados no Comércio de Santos. Pesquisa: Gazeta Sindical/maio-1998 e artigos do Diário Popular e Folha de São Paulo. 


\subsection{3 - SINISTROS MARÍTIMOS}

O Porto de Santos destaca-se como o maior da América Latina, registrando grande movimentação de navios de todos os tipos, vindos de todas as partes do mundo. Entre 1822 e 1996, o porto santista recebeu cerca de 45 mil embarcações diferentes, que indicam uma média de operações anuais em torno de 3 mil manobras por ano. Porém, considerando a presença de tantos navios e a sua movimentação constante, o índice de acidentes é quase insignificante. Felizmente, os poucos sinistros marítimos ocorridos na bacia portuária santista provocaram mais danos materiais do que vítimas. ${ }^{341}$

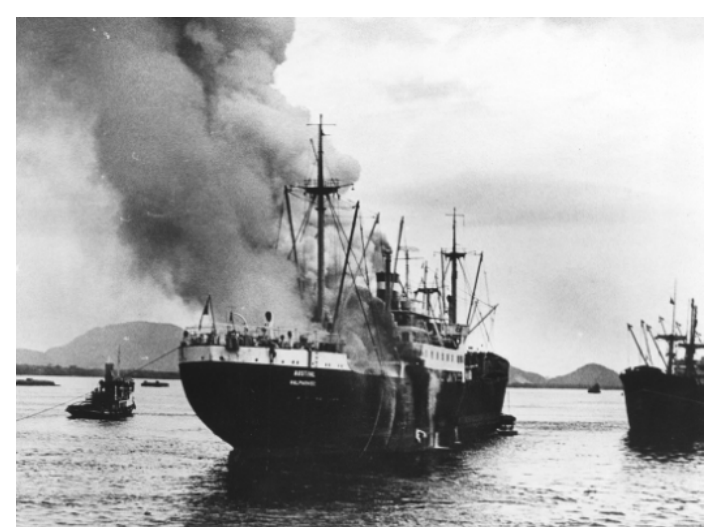

Incêndio do Navio Austral. Porto de Santos, 02 de janeiro de 1967. Gelatina/prata, $24 \times 36 \mathrm{~cm}$. Acervo FAMS.

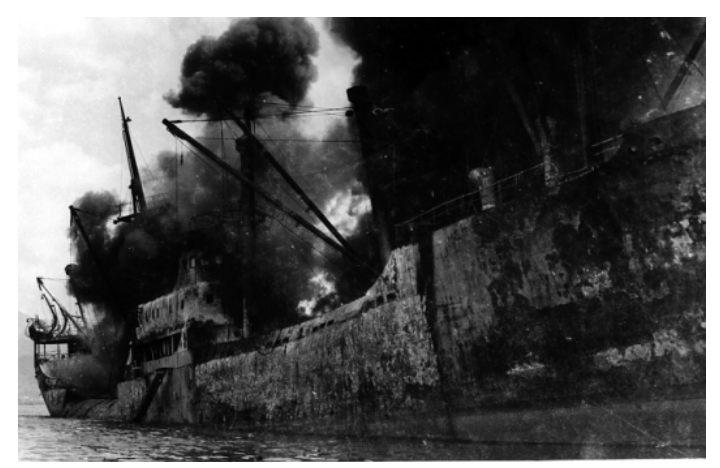

Incêndio do Navio Ais Giorgis. Porto de Santos, 09 de janeiro de 1974. Gelatina/prata, 24×36cm. Acervo FAMS.

\footnotetext{
${ }^{341}$ LICHTI, Fernando Martins. História de Santos - Poliantéia Santista, 1996, p.105.
} 


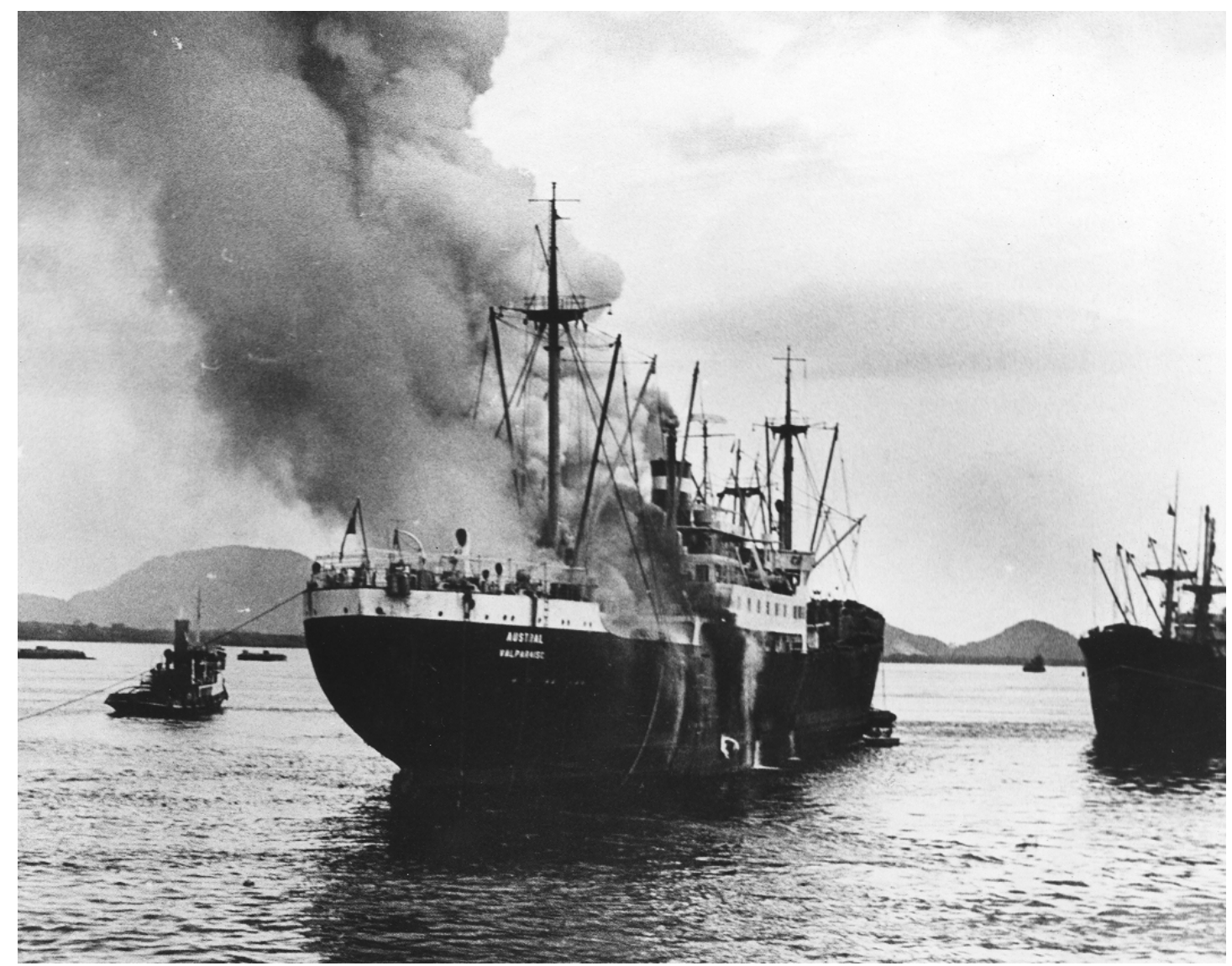

Incêndio do Navio Austral no Porto de Santos, em 02 de janeiro de 1967.

Vemos na imagem o navio chileno Austral em chamas sendo rebocado, na tarde de 02 de janeiro de 1967, no Porto de Santos. Ao lado direito, outro navio cargueiro. Ao fundo, o distrito de Vicente de Carvalho, no Guarujá. José Herrera recorda que chegou a fotografar o incêndio em vários momentos:

Quando eu recebi o aviso do incêndio, corri para pegar um aviãozinho na Base Aérea... As primeiras fotos que tirei do Austral foram aéreas. Mais tarde, peguei um barco para chegar mais próximo do navio. Eu me lembro que cheguei a voltar lá pelo menos mais uma vez... Ele (o navio) pegou fogo atracado perto do cais e precisou ser rebocado porque estava ameaçando os armazéns... Então, eu tive que acompanhar o processo. ${ }^{342}$

${ }^{342}$ Depoimento do fotógrafo. 18/10/2005. 
Com carregamento de salitre e moedas cunhadas, o Austral estava atracado junto ao Armazém 25. O incêndio não foi controlado a tempo e a embarcação foi toda destruída. $O$ fogo teve início no porão 4 , em uma lingada ${ }^{343}$ de sacos de salitre que estava sendo descarregada. Em poucos minutos, as labaredas atingiram cerca de 30 metros de altura, ultrapassando a extremidade dos mastros e paus-de-carga do navio. O Austral foi desatracado e rebocado até Conceiçãozinha, na outra margem do estuário, à altura do Armazém 29. Sucessivas explosões fizeram com que as chamas se propagassem, atingindo o porão 5 e a casa das máquinas. Por determinação da Capitania dos Portos, o canal do estuário foi imediatamente interditado, enquanto rebocadores combatiam o incêndio. As chamas só foram apagadas por volta das 6 horas da manhã do dia 3 de janeiro. Porém, na manhã do dia 4 de janeiro, o fogo voltou a arder na altura da casa das máquinas e os bombeiros foram obrigados a retornar ao navio. O Austral ficou completamente destruído, restando somente o casco e um monte de ferros retorcidos e enegrecidos. As origens do incêndio foram atribuídas à combustão espontânea. As caixas contendo as moedas uruguaias foram retiradas dias após intactas e o Austral foi posteriormente desmontado em Santos pela empresa Grieves. ${ }^{344}$

O fotógrafo se recorda que aconteceram inúmeros incêndios de navios no Porto de Santos:

Aqui nesse Porto eu fotografei muitos incêndios de navios. Acontecia demais. Eles vinham descarregar, aí acontecia algum acidente, alguma faísca, e começava o fogo. Hoje em dia, os navios têm um esquema de segurança e prevenção de incêndios. Eles se preocupam e se previnem... Antigamente, não era assim. A carga vinha desprotegida e a tripulação não era cuidadosa. ${ }^{345}$

\footnotetext{
${ }^{343}$ Conjunto de sacos, numa amarração com cordas, que é içado de uma só vez pelo guindaste.

${ }^{344}$ ROSSINI. José Carlos, Sinistros Marítimos - Costa do Estado de São Paulo / 1900-1999, p.46.

345 Depoimento do fotógrafo. 18/10/2005.
} 


\subsection{4 - TRANSATLÂNTICOS}

A primeira fase dos transatlânticos em Santos perdurou até o final da década de 1960. Foram tempos dourados, em que o cais vivia repleto de pessoas embarcando e desembarcando. Em um só dia, vários transatlânticos atracavam no Porto. O movimento de embarcações, somando os cargueiros, era impressionante, causando congestionamentos. Nesta época, passaram por Santos cerca de 1500 navios de passageiros. ${ }^{346}$

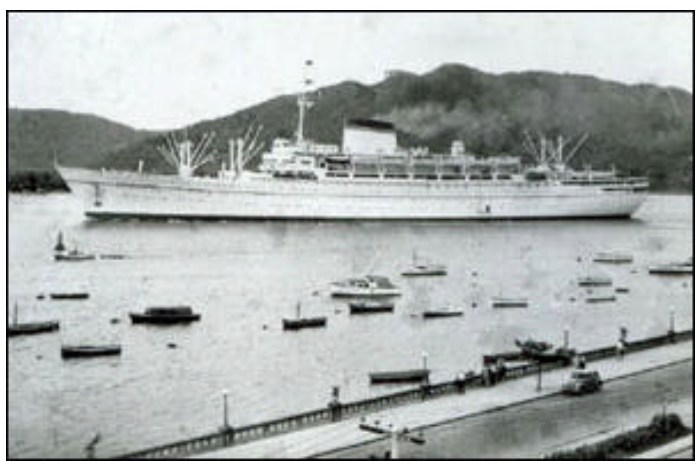

O célebre transatlântico Giulio Cesare, irmão do Augustus, passando pela Ponta da Praia Santos, Meados da década de 1950. Reprodução do site www.portogente.com.br. Acervo José Laire Giraud.

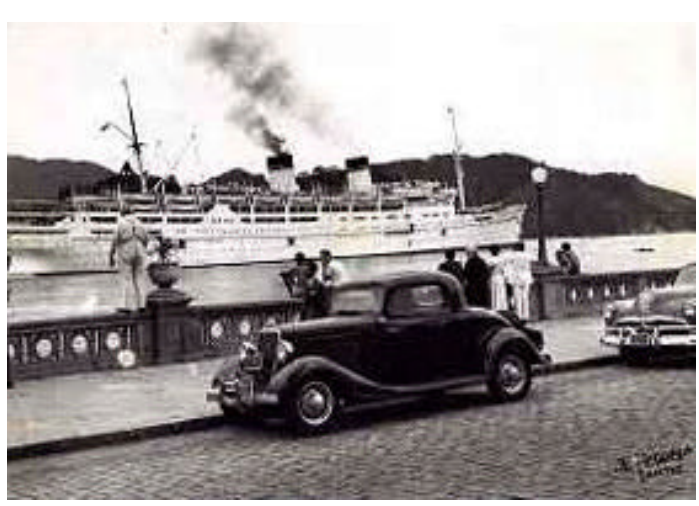

Passagem do transatlântico Conte Grande na Ponta da Praia. Santos, 1952. Gelatina/prata, $24 \times 36 \mathrm{~cm}$. Acervo particular José Dias Herrera 


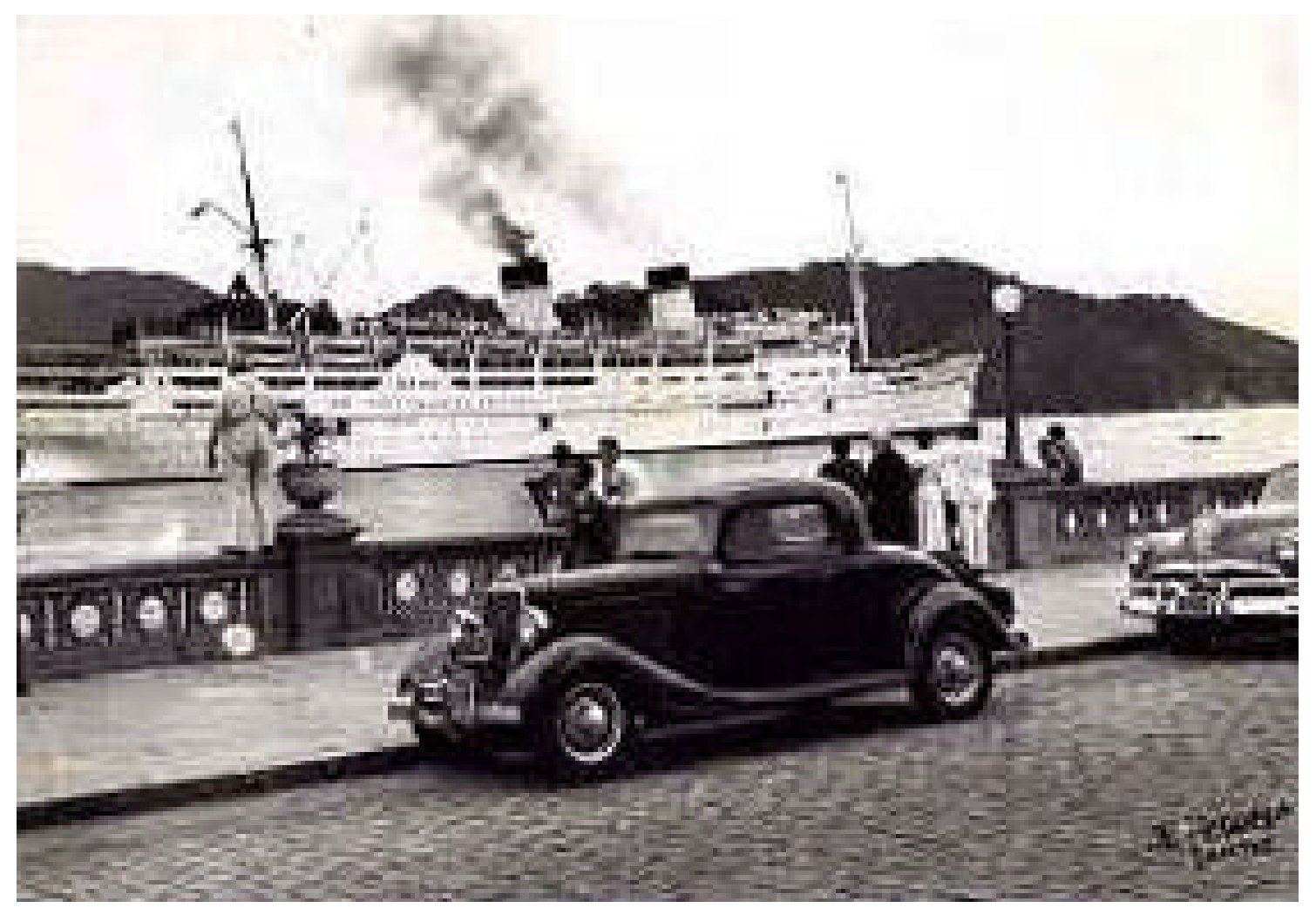

O transatlântico italiano Conte Grande passando em frente à Av. Saldanha da Gama, na Ponta da Praia, no ano de 1952.

Observando a foto, percebe-se como o navio passa próximo da mureta, dando a impressão de poder tocá-lo. Pessoas esperam a passagem da embarcação apoiadas, sentadas e até de pé na famosa mureta da orla da praia, que na época era adornada com vasos (à esquerda) e postes de iluminação (à direita). Percebe-se ainda que a rua era de paralelepípedos. Ao fundo, os morros já pertencem ao município de Guarujá. Vale destacar que o transatlântico Conte Grande fazia par com o Conte Biancamano.

José Herrera lembra que os navios eram de diversas nacionalidades e que as suas escalas eram regulares, ou seja, aconteciam durante o ano inteiro.

Pelo menos, de 20 em 20 dias, chegavam transatlânticos em Santos. Os navios eram de todos os tipos, desde os mais luxuosos até os mais modestos, e vinham de vários lugares: Argentina, Alemanha, França, Inglaterra, Estados Unidos, Portugal e até do 
Japão[...] O mais famoso era o Eugenio Costa (de bandeira italiana), do qual todo mundo já ouviu falar um dia... ${ }^{347}$

Laire José Giraud, em sua obra Transatlânticos em Santos - 1901/2001, cita, inclusive, os transatlânticos brasileiros: Bagé, Rodrigues Alves, Campos Sales e Siqueira Campos, que faziam a linha regular para a Europa, antes da Segunda Guerra Mundial (1939-1945). O autor destaca ainda que um dos navios norteamericanos foi batizado com o nome Brazil. ${ }^{348}$

O fotógrafo conta também que sempre tinha 'alguém importante' viajando num transatlântico, mas que, quase nunca, essas pessoas desembarcavam na Cidade. Por isso, sempre que chegava um navio, ele tinha que entrar a bordo. Para fotografar os passageiros e ganhar tempo, chegava no Porto às 5 horas da manhã com o objetivo de pegar 'uma carona' com a lancha da Polícia Marítima.

Eles iam vistoriar os navios para autorizar a atracação muito cedo e eu aproveitava para ir também. Daí eu entrava no navio, era recebido pelo comandante, tomava o meu café da manhã lá, entrevistava alguma personalidade... E pronto! Quando o navio atracava, eu já tinha feito o meu serviço, desembarcava e corria para outro trabalho. Não podia esperar! ${ }^{349}$

A época glamourosa dos transatlânticos em Santos está de volta. As armadoras unidas com os agentes de viagens deram aos navios de passageiros uma nova finalidade: o turismo de lazer. A primeira temporada desta 'nova fase' aconteceu em 1999/2000 e, a partir daí, temos a oportunidade de ver os mais famosos e luxuosos transatlânticos atracando no Porto de Santos. Mas, Herrera ressalta:

\footnotetext{
${ }^{347}$ Depoimento do fotógrafo, em 13/02/2006.

348 Laire José Giraud, Transatlânticos em Santos / 1901-2001, p.13 e 14.

${ }^{349}$ Depoimento do fotógrafo, em 13/02/2006.
} 
Só que agora é diferente. Os transatlânticos não estão aqui durante $\mathrm{o}$ ano inteiro, como acontecia antigamente. Por outro lado, parece que a população dá mais valor. Hoje, a Ponta da Praia fica abarrotada de gente para ver a saída dos navios, já virou atração. [...] Pra mim, esse vai-e-vem dos navios sempre foi um espetáculo. ${ }^{350}$

${ }^{350}$ Depoimento do fotógrafo. 13/02/2006. 


\subsection{5 - NAVIOS DE GUERRA}

Navios militares sempre exercerão fascínio. São armas poderosas vestidas em barcos de formas elegantes. Quem vive em uma cidade portuária como Santos, mesmo sem sediar uma base da Marinha, mantém uma relação de proximidade forçada com esses poderosos armamentos [...] A fila de centenas de pessoas muito mais santistas e habitantes da região que turistas - interessadas em ver os navios de perto durantes as visitas da armada ao porto, são uma mostra concreta dessa intimidade e, até, do orgulho de tê-los por perto. ${ }^{351}$

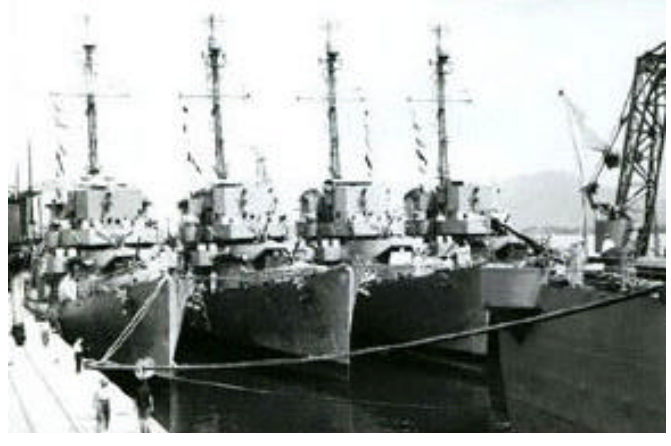

Os contratorpedeiros Bauru, Beberibe, Bocaina e Bertioga, que escoltavam o cruzador Barroso em suas viagens pelos portos do Brasil. A foto foi tirada a partir da popa do Barroso. Porto de Santos. 1955 Reprodução do site www.portogente.com.br. Acervo L.J. Giraud.

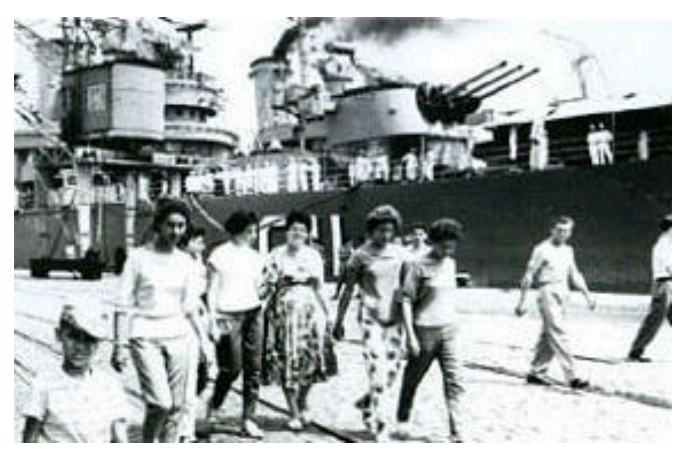

Família deixando o cais após visita ao cruzador Barroso. Porto de Santos. 1961. Reprodução do site www.portogente.com.br. Acervo L.J. Giraud.

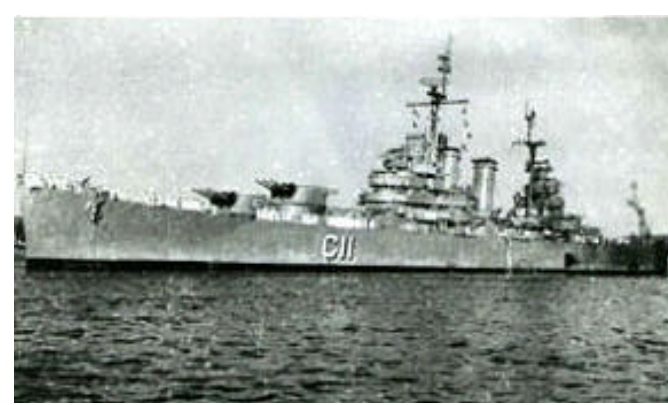

O cruzador brasileiro Barroso, de prefixo C11, manobrando no Estuário de Santos. 1958. Reprodução do site www.portogente.com.br. Acervo L.J. Giraud.

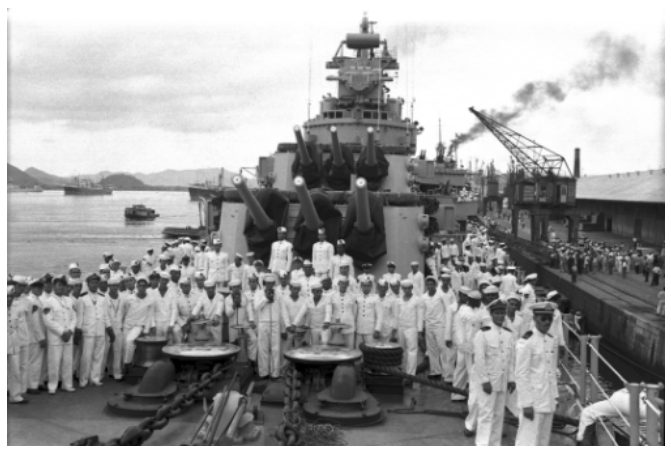

Oficiais e praças do cruzador Barrosc. Porto de Santos. 1960. Gelatina/prata, $24 \times 36 \mathrm{~cm}$ Acervo FAMS.

${ }^{351}$ Bem perto das grandes armas. Jornal da Orla, Santos, 27 de agosto de 2005, p.09. 


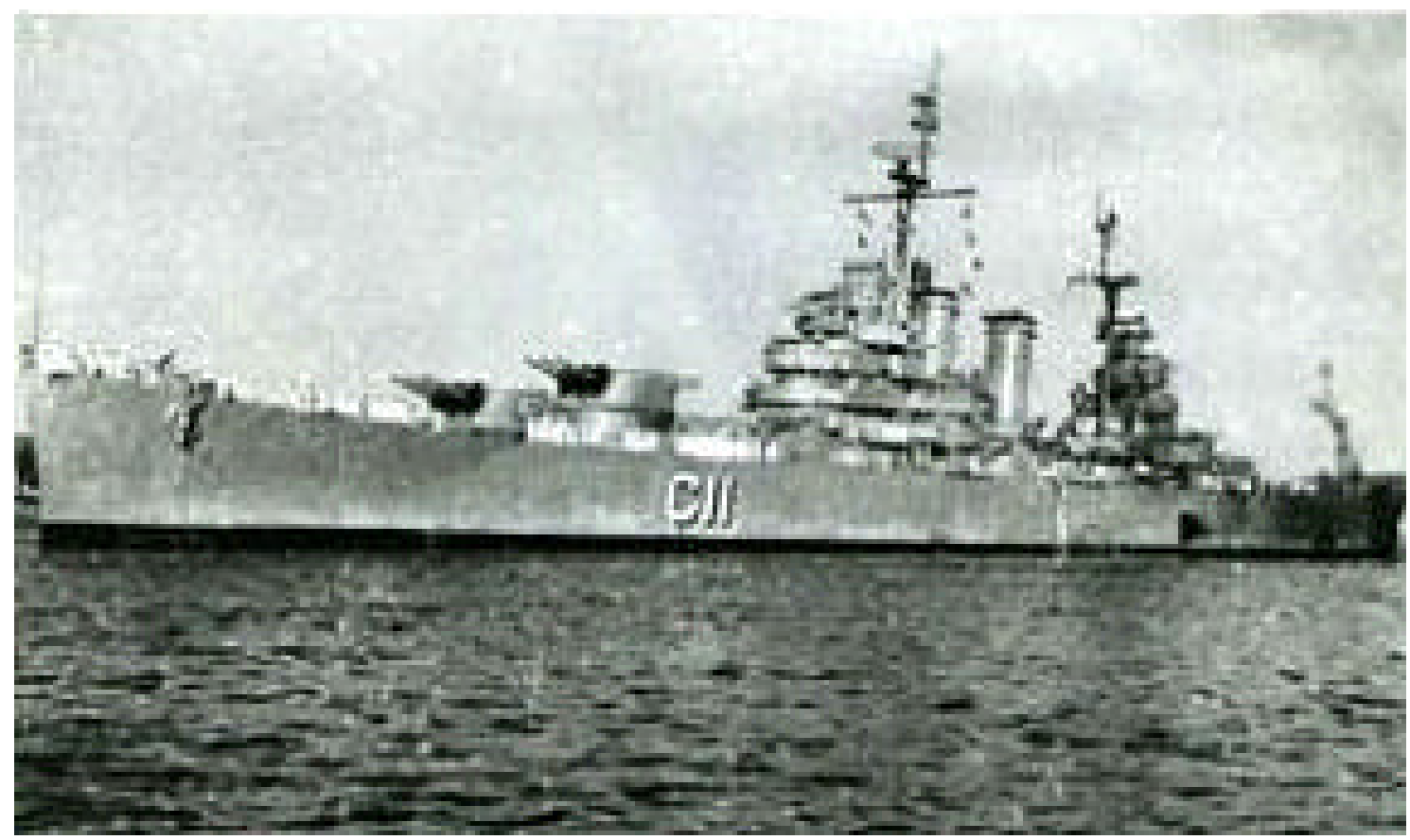

O cruzador Barroso, da Marinha de Guerra do Brasil, cujo prefixo era C11 (inscrição no casco), manobrando no estuário de Santos, em 1958.

José Herrera lembra da presença dos navios de guerra no Porto santista:

Os navios de guerra sempre vinham para Santos, principalmente em exercício de tiro, que era realizado na Laje de Santos [...] Normalmente a embarcação ficava alguns dias aberta para a visitação pública, atracada principalmente no Armazém 5, da Companhia Docas [...] Vinham famílias inteiras conhecer o navio, era um programa diferente para o final de semana. Hoje, as pessoas não se interessam como antigamente. ${ }^{352}$

O cruzador Barroso foi desativado aos 37 anos, sendo 22 de Marinha brasileira. Sua história é cheia de fatos e atividades realizadas em todo o tempo em que permaneceu no mar, percorrendo um total de 243.464 milhas. Foi construído no Arsenal de Marinha de Filadélfia, por encomenda da marinha norte-americana, e teve sua quilha batida a 28 de maio de 1935. Foi lançado ao mar em 17 de novembro de 1936, com o nome de US Philadelphia. Com essa denominação, hospedou, em 1938, o presidente Roosevelt, participou da II Guerra Mundial e

${ }^{352}$ Depoimento do fotógrafo. 13/02/2007. 
transportou o presidente Truman até Potsdam. Como barco brasileiro, participou do desfile de coroação da rainha da Inglaterra, transladou os restos mortais da Princesa Isabel e do Conde D’Eu, além de participar de várias missões militares.

Outros serviços que o Barroso executou foi transportar o presidente português, Craveiro Lopes, de Salvador para o Rio de Janeiro; foi a Portugal participar das comemorações henriquinas; tomou parte na chamada "Guerra da Lagosta" e transportou o ex-presidente Juscelino Kubitschek a Portugal. Durante o tempo em que esteve a serviço do Brasil, percorreu milhares de milhas, a uma velocidade máxima de 30 nós. O Barroso tinha comprimento de 185 metros, calado de 7,30 metros e deslocamento de 14 mil toneladas. Seu raio de ação era de 8.900 milhas e seu armamento principal estava montado em 5 torres tríplices, com canhões de 6 polegadas, permitindo volume total de fogo equivalente a 7 batalhões de artilharia de 105 milímetros. Sua guarnição era composta de 1.003 homens (57 oficiais) e a potência de suas máquinas era de 100 mil HP, o que daria para iluminar uma grande cidade. O Barroso foi desmontado no ano de 1973, em Vicente de Carvalho, distrito do Município de Guarujá, cidade que integra o complexo do Porto de Santos. ${ }^{353}$

\footnotetext{
${ }^{353}$ A despedida de um velho barco que foi de guerra. A Tribuna. Santos, 8 de julho de 1973.
} 


\subsection{Pelé e o Santos Futebol Clube}

Apesar de ser 'especializado em tudo', como gosta de dizer, José Herrera dedicou muitos anos da sua carreira à cobertura de futebol, especialmente do Santos Futebol Clube. O fotógrafo viajou por todo o Brasil e o mundo acompanhando os jogos do time: inicialmente, na década de 1940, trabalhando para o jornal O Diário, depois, a partir de 1953, como setorista do jornal A Tribuna e, ao mesmo tempo, realizando serviços avulsos para a Gazeta Esportiva, Folha de São Paulo, O Estado de São Paulo e O Esporte.

No começo, antes de Pelé, eu trabalhava no Diário e ia acompanhando o time somente para as cidades do interior e para outros estados. Quando o Pelé chegou, daí eu comecei a sair do Brasil. Na Tribuna, eu fui muito para fora, conheci vários países: Argentina, Uruguai, Paraguai, França, Espanha, Bélgica, Polônia, Portugal, Itália, Alemanha, Suíça, quase tudo [...] Houve uma época em que eu vendia muita foto para outros jornais. Eu podia fazer uma ou duas fotos para o Diário em cinco minutos e ir embora, mas não. Eu acompanhava e fotografava praticamente os jogos inteiros para poder produzir uma grande quantidade de fotos para vender. Daí, eu corria para o laboratório, revelava e ampliava tudo e mandava para São Paulo para uma porção de jornais, que não mandavam ninguém para cobrir os jogos porque sabiam que podiam contar com os meus serviços. ${ }^{354}$

E José Herrera também confessa que foi a convivência com o time que o transformou em um torcedor santista:

Eu torcia para o Corinthians porque a minha família era toda descendente de espanhóis e os espanhóis lá em São Paulo eram todos corintianos. Então, eu também peguei a mania de ser corintiano. Quando eu vim para Santos e comecei a trabalhar no

${ }^{354}$ Depoimento do fotógrafo. 31/05/2007. 
Diário, o Santos Futebol Clube virou a minha segunda casa e eu me tornei santista, claro. Todo dia eu acompanhava os treinos, entrevistas, os jogos. E virei santista e sou santista até hoje. E virei santista muito antes de Pelé. 


\subsection{1 - A CHEGADA DE PELÉ}

Pelé chegou ao Santos Futebol Clube em 1956, com 16 anos. Com a fama de craque e o 'apadrinhamento' de Valdemar de Brito, ex-técnico do Baquinho, já começou treinando entre os profissionais. Sua atuação impressionava e, em pouco tempo, conquistou um lugar definitivo no time titular. A estréia entre os profissionais aconteceu em um amistoso contra o Corinthians de Santo André. O time vencia por $5 \times 0$, quando o ponta-de-lança Del Vecchio se machucou e Pelé foi chamado para substituí-lo. Na ocasião, já marcou um gol - o primeiro com a camisa do SFC. ${ }^{355}$

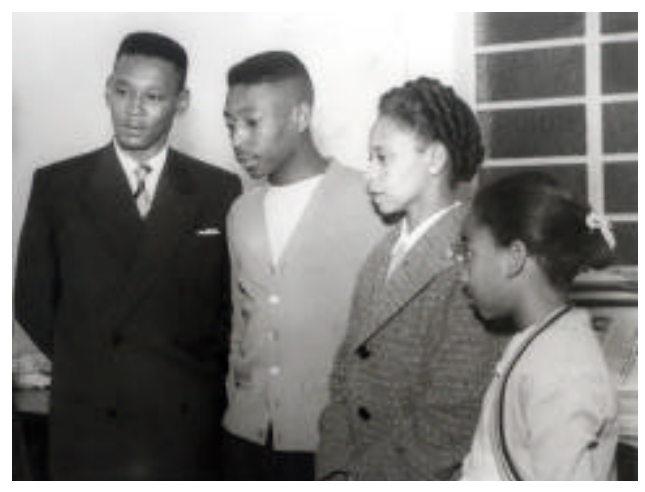

A primeira foto de Pelé tirada por José Herrera. $\mathrm{Na}$ imagem, o craque está no meio dos pais, Seu Dondinho (João Ramos) e Dona Celeste e, à direira, está a sua irmã, Maria Lúcia Nascimento. Ano de 1956, assim que a família chega ao Santos Futebol Clube. Reprodução Acervo José Herrera.

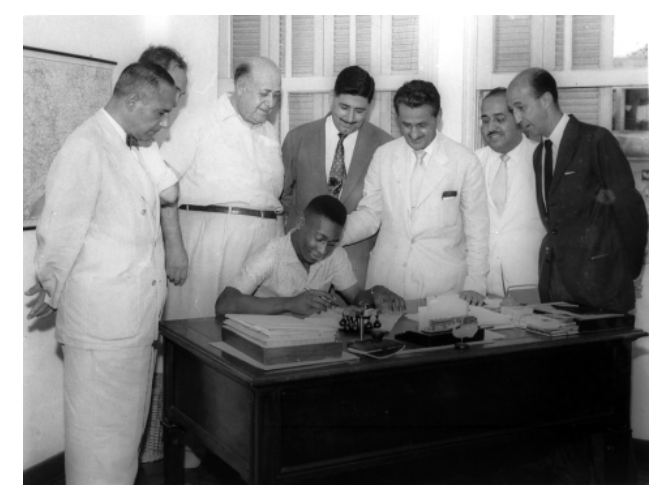

Pelé assinando o contrato com o Santos Futebol Clube, assim que chegou na Vila Belmiro. Santos. 1956. Reprodução Acervo José Herrera.

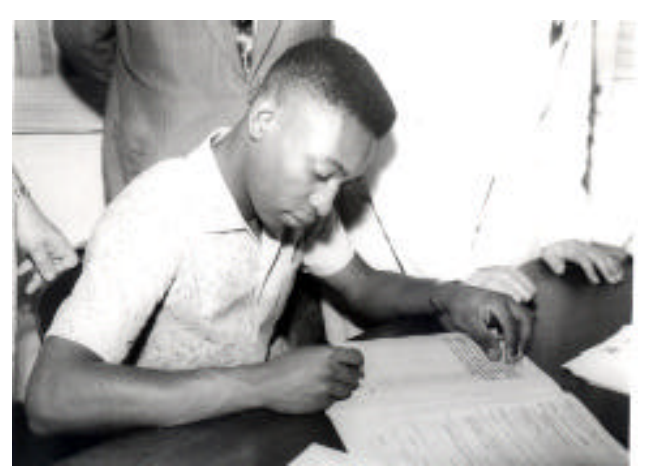

Pelé assinando o contrato com o Santos Futebol Clube, assim que chegou na Vila Belmiro. Santos. 1956. Reprodução Acervo José Herrera.

\footnotetext{
${ }^{355}$ Site oficial do Santos Futebol Clube: www.santos.globo.com/clube_historia_pbiografia
} 


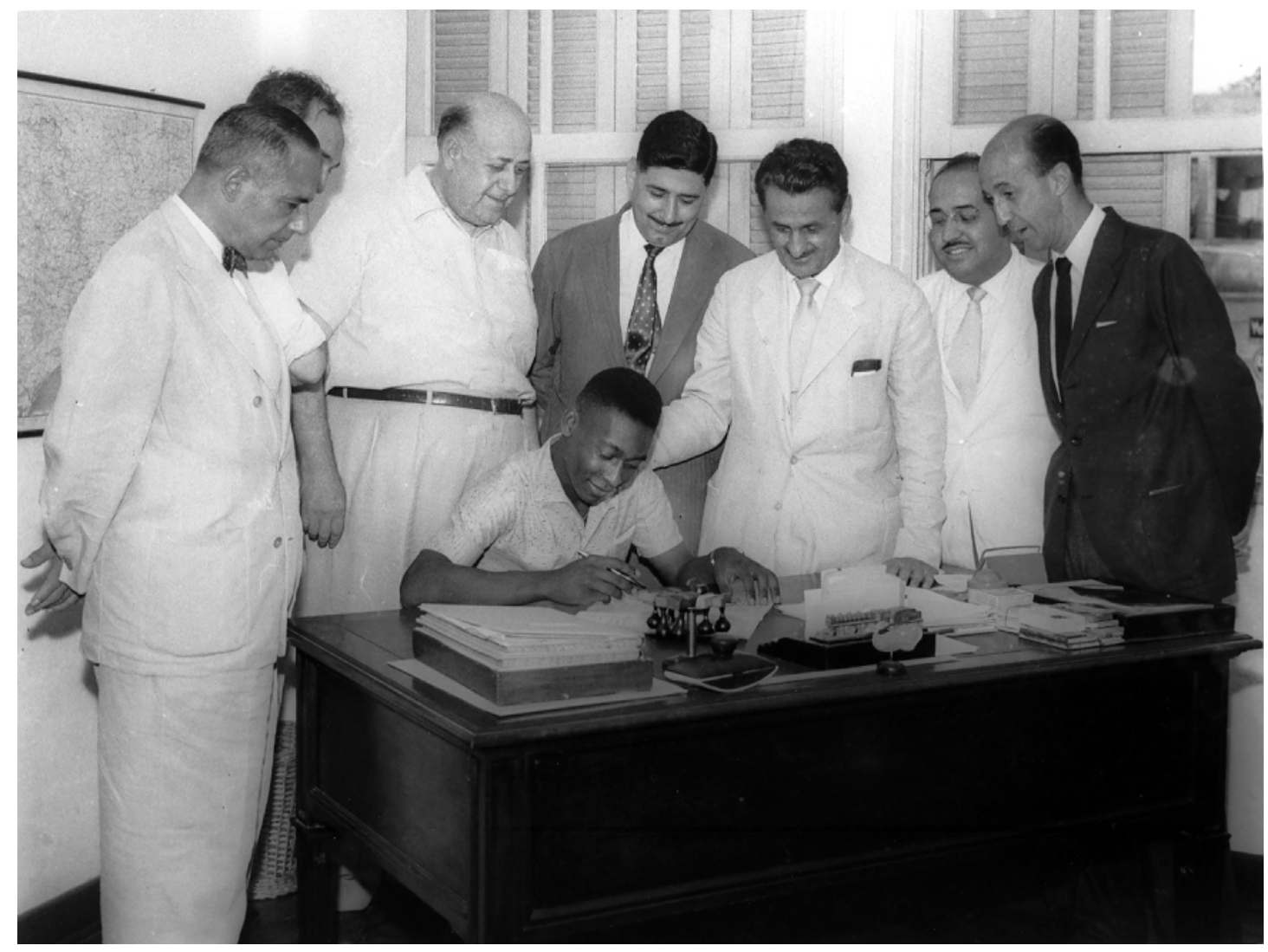

Pelé assinando o contrato com o Santos Futebol Clube, assim que chegou na Vila Belmiro, em Santos, no ano de 1956.

A foto mostra o garoto Pelé assinando o contrato com o Santos Futebol Clube, assim que chegou na Vila Belmiro, no dia 8 de agosto de 1956. Na ponta direita, de terno escuro, o cronista esportivo do jornal A Tribuna, Adriano Neiva de Motta e Silva, o De Vaney. Ao seu lado, o médico do SFC, Newton de Lima Azevedo. Colocando a mão sobre o ombro de Pelé, o então diretor do clube Athié Jorge Coury e, ao seu lado esquerdo, de terno cinza, o também diretor Augusto da Silva Saraiva. Atrás de Pelé, de camisa de manga curta branca e cinto preto, o então presidente do clube, Modesto Roma.

José Herrera se recorda muito bem deste dia: 
uma camiseta do clube às pressas para poder fotografá-lo. A primeira foto dele com a camisa do alvinegro foi eu quem tirei, e já era a camisa 10. 


\subsection{2 - PELÉ NO SANTOS FUTEBOL CLUBE E NA SELEÇÃO BRASILEIRA}

Durante a sua longa trajetória, Pelé conseguiu, pelo Santos Futebol Clube, os títulos de Campeão Paulista (1958, 1960/61/62, 1964/65, 1967/68/69 e 1973), da Taça Brasil (1961/62/63/64/65), do Robertão (1968), do Rio-São Paulo (1959, 1963/64), da Taça Libertadores (1962/63) e Mundial Interclubes (1962/63). Já pela seleção brasileira, entrou em campo 11 vezes, marcou 95 gols e conquistou o título de Campeão Mundial nos anos de 1958, 1962 e 1970. Em toda a sua carreira foram 1.281 gols marcados. ${ }^{356}$

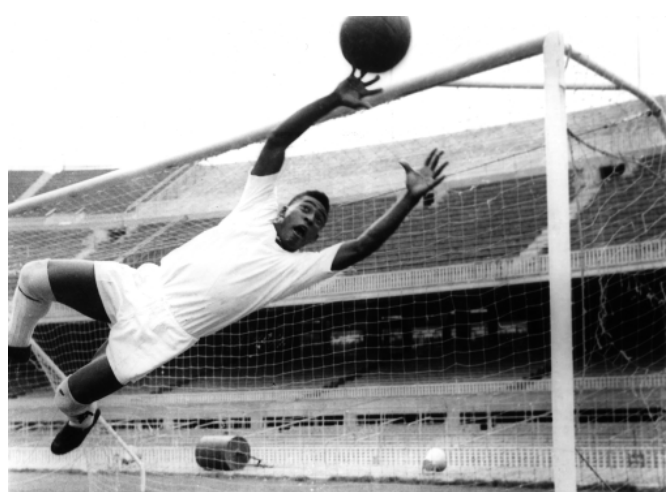

Pelé também jogava no gol, pois era o reserva imediato do goleiro Gilmar. Década de 1960. Reprodução Acervo Pelé.

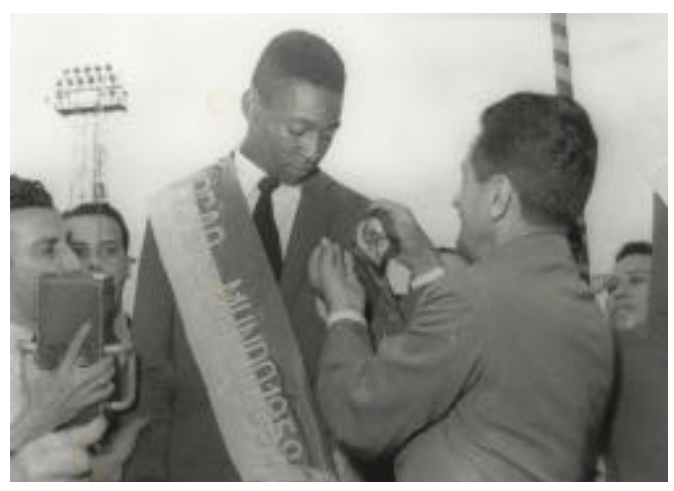

Pelé recebendo a faixa e medalha de Campeão do Mundo em 1958 pela seleção brasileira. Reprodução Acervo Pelé.

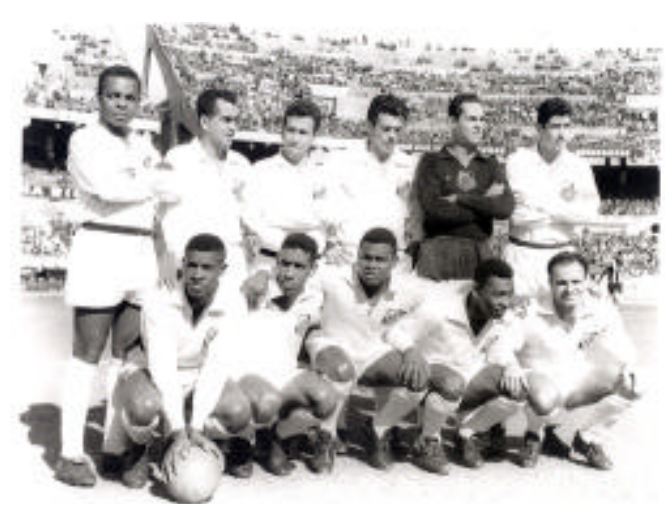

Time de 1963 do Santos Futebol Clube. Reprodução Acervo particular José Dias Herrera..

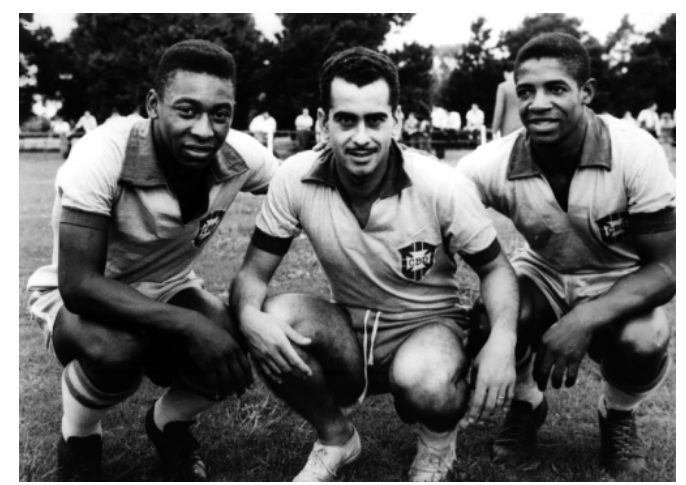

Pelé, Zito e Dorval - companheiros na Seleção Brasileira. Reprodução Acervo Pelé.

${ }^{356}$ Site oficial do Santos Futebol Clube: www.santos.globo.com/clube_historia_pbiografia 


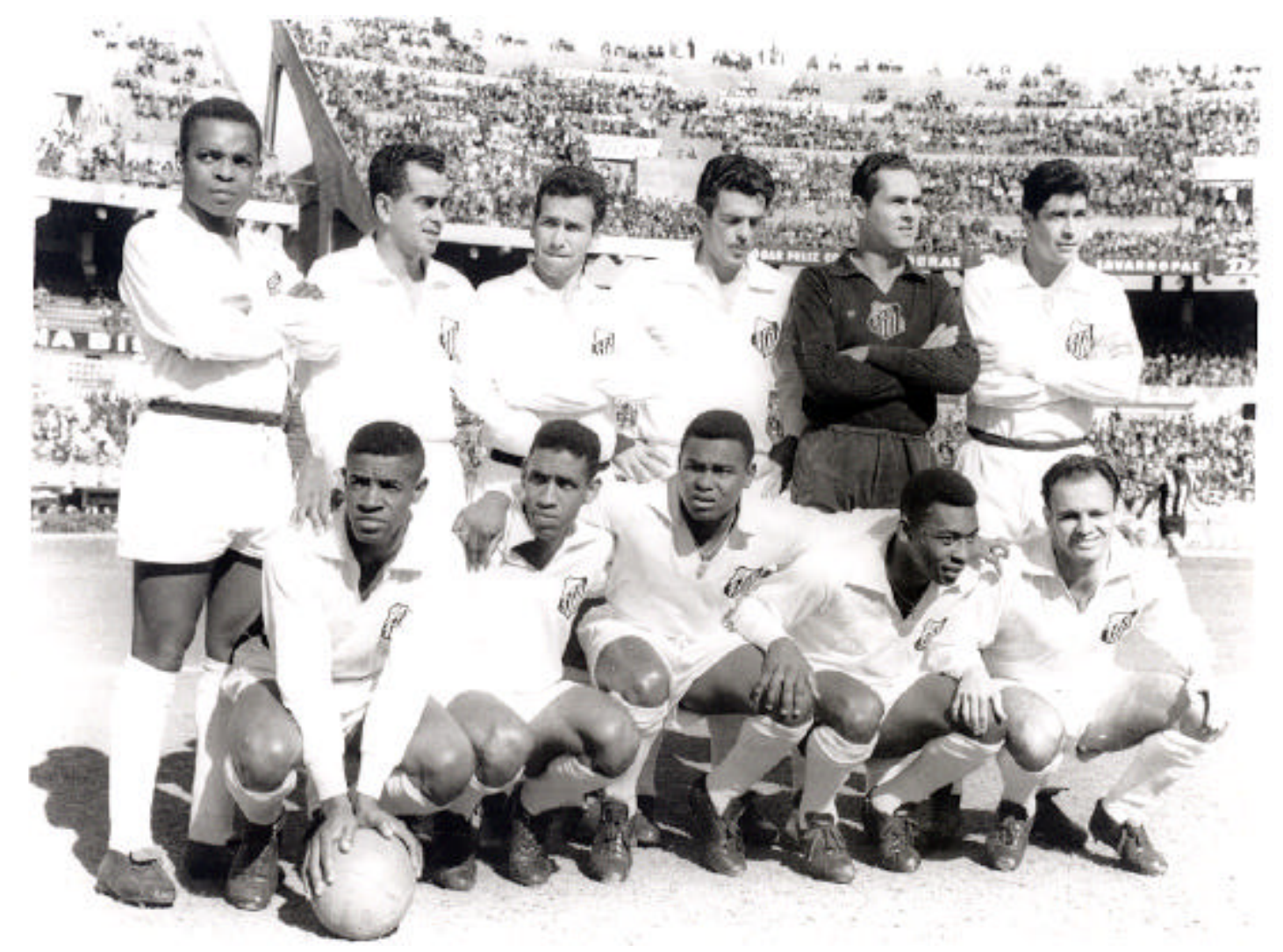

Time de 1963 do Santos Futebol Clube.

A imagem mostra o time do Santos Futebol Clube no Monumental de Nuñes, Ila Argentina, em 1963, posando para foto. Da esquerda para a direita, a turma de pé: Nilmar, Zito, Dalmo, Calvet, o goleiro Gilmar e Mauro. Da esquerda para direita, agachados: Dorval, Mengálvio, Coutinho, Pelé e Pepe. Podemos notar que o uniforme dos jogadores é composto de shorts, camiseta de manga comprida e meião brancos, além da chuteira e do cinto pretos.

Pelé começou a defender o Santos Futebol Clube em 1956 e, já em 1957, foi convocado para usar a camisa verde e amarela, levando o país a conquistar o título de campeão da Copa Roca - o seu primeiro título internacional e com a camisa da Seleção Brasileira. O sucesso continuou no SFC durante a disputa do Campeonato Paulista de 1957, do qual foi artilheiro, fazendo 36 gols. Em 1958, veio a sua 
primeira Copa do Mundo, com vitória - foi o primeiro título mundial da Seleção Brasileira e Pelé tinha apenas 17 anos.

Após essa vitória, ainda vieram a conquista do Campeonato Paulista de 1958 e do Torneio Rio-São Paulo de 1959, ambos pelo Santos Futebol Clube. Entre os anos de 1959 e 1961, o time conseguiu conquistar 11 títulos internacionais e, em 1962, foi campeão sul-americano. Reconhecida e respeitada internacionalmente, na década de 1960, a equipe santista conquistou oito campeonatos paulistas, e Pelé foi coroado como artilheiro em quase todos.

No ano de 1962, a Seleção Brasileira, cujo principal jogador era Pelé, disputou e venceu mais uma Copa do Mundo. Na copa seguinte, em 1966, a seleção foi eliminada logo na primeira fase, mas, em 1970, conquistou o Tri-campeonato. Foi a última participação de Pelé em copas do mundo. ${ }^{357}$

A sua despedida oficial da Seleção Brasileira aconteceu em 11 julho de 1971, em um amistoso contra a Áustria, no Morumbi, com um público de quase 100 mil torcedores. Três anos depois, chegou a vez de dar adeus ao Santos Futebol Clube, durante uma partida contra a Ponte Preta. A despedida definitiva do futebol veio em 1977, no amistoso Cosmos (o time americano pelo qual Pelé jogou quando saiu do Santos) e Santos. ${ }^{358}$

\footnotetext{
${ }^{357}$ Site oficial do Santos Futebol Clube: www.santos.globo.com/clube_historia_pbiografia

358 Site oficial do Santos Futebol Clube: www.santos.globo.com/clube_historia_pbiografia
} 


\subsection{3 - PELÉ E A VIDA PESSOAL}

Acompanhar os treinos, jogos e até o dia-a-dia do Santos Futebol Clube aproximou muito José Herrera de todos os jogadores, inclusive de Pelé.

A convivência praticamente me tornou o fotógrafo oficial do Pelé naquele tempo. Por causa da proximidade, eu comecei a fazer fotos particulares para ele. Ele tinha uma firma, um escritório de representações, ou alguma coisa assim, e eu fotografava os produtos que ele negociava... Fotografei também o namoro dele, o casamento, os filhos, o cotidiano mesmo. Lembro até dos pais dele, eram muito boa gente... Eles moraram no José Menino. ${ }^{359}$

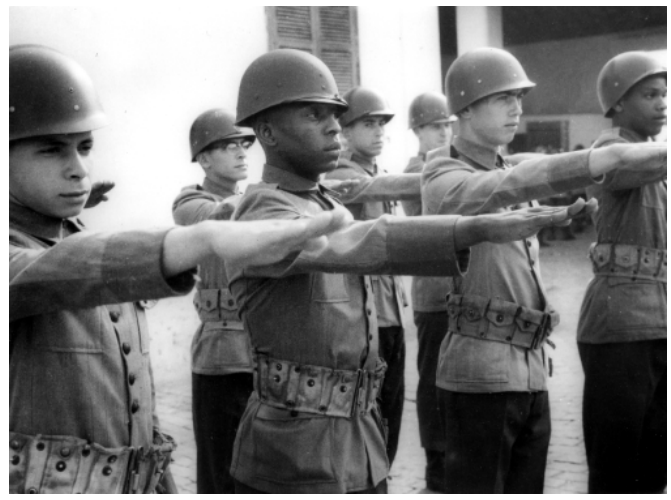

Pelé servindo o exército no $2^{\circ}$ Batalhão de Caçadores de São Vicente. 1958. Reprodução acervo particular José Herrera.

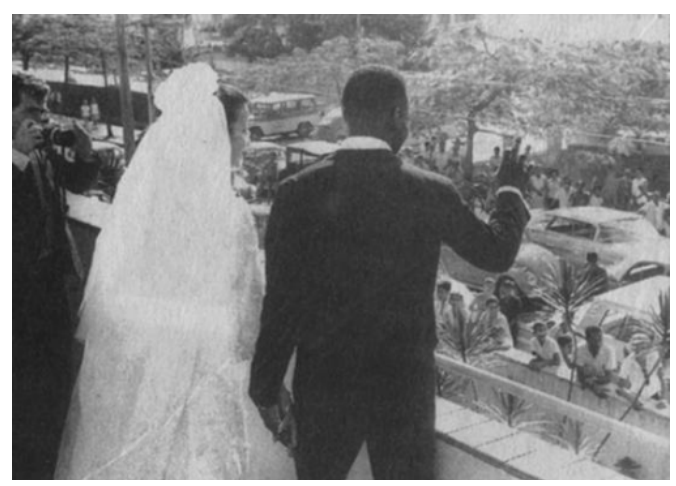

Pelé em seu primeiro casamento, na sacada da casa da noiva, no bairro do Macuco, agradecendo a presença do público. Santos. 1966. Reprodução Acervo particular José Herrera.

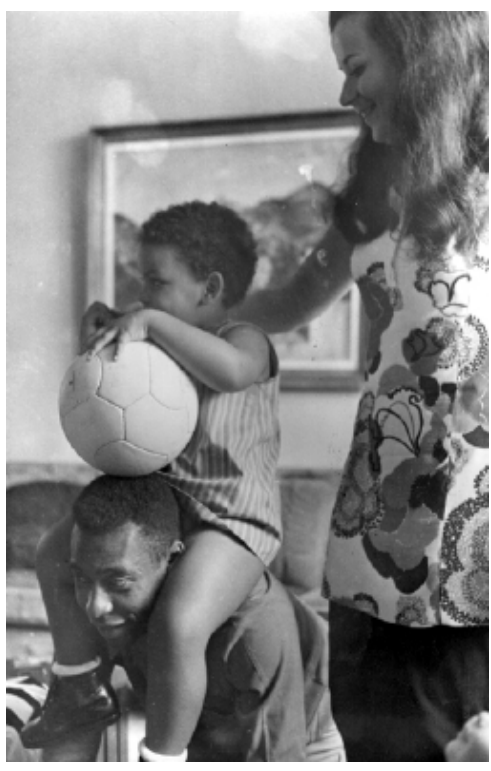

Pelé brincando a filha mais velha da união com Rosemeri. Final da década de 1960. Reprodução Acervo particular José Herrera.

${ }^{359}$ Depoimento do fotógrafo. 31/05/2007. 


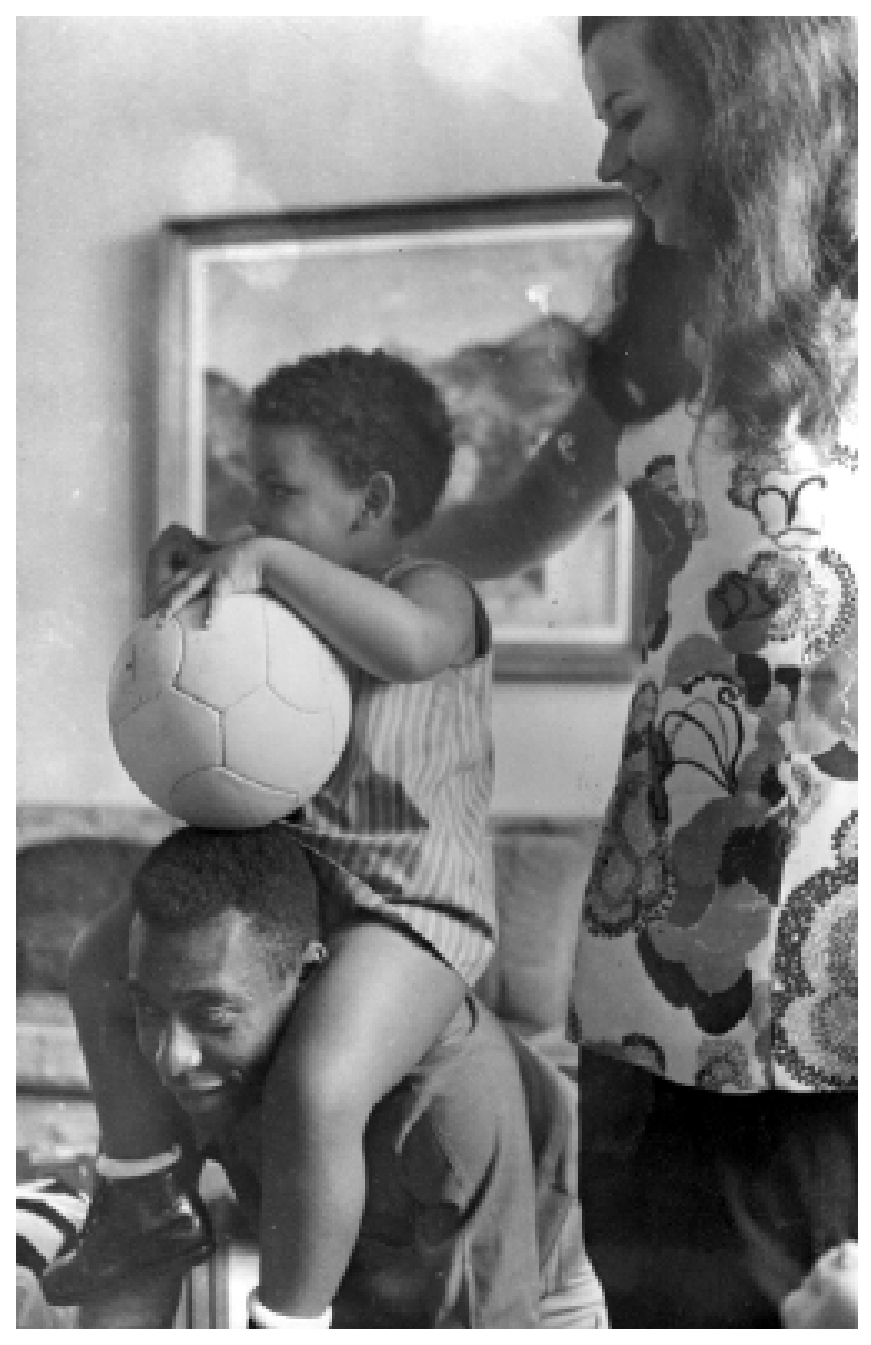

Pelé brincando com a filha Jenifer em sua residência em Santos, no final da década de 1960.

A foto mostra Pelé brincando de cavalinho com Jenifer, a sua primeira filha da união com Rosemeri Cholbi, que aparece ao lado deles de bata estampada. Nota-se que a menina já segura uma bola de futebol. O casamento entre Pelé e Rosemeri durou de 1966 até 1978, e gerou mais dois filhos: Edinho e Kelly Cristina.

José Herrera conta que não mantém mais uma relação de proximidade com Pelé, mas possui uma bola autografada e algumas fotos. Há alguns anos, o Rei comprou o acervo de imagens que o fotógrafo possuía dele. 


\section{Considerações finais}

Ao longo desta dissertação, procuramos resgatar os elementos que marcaram a história da cidade de Santos, os aspectos particulares da vida do fotógrafo José Dias Herrera e sua visão dos eventos que documentou. O balizamento temporal vai do final da década de 1930, quando o fotógrafo iniciou a sua carreira até os dias atuais, visto que Herrera continua praticando seu ofício de fotógrafo. Nossa análise foi mais intensiva do período que vai de 1937 à retomada da autonomia da cidade de Santos em 1984.

Tal período inclui os principais dramas históricos pelos quais o Brasil passou no decorrer do século XX: a ditadura do Estado Novo com a conseqüente intervenção federal na cidade e o amordaçamento da imprensa; a Segunda Guerra Mundial e a breve atuação de Herrera como speaker de rádio; a modernização e a remodelação da paisagem nas décadas de 1950 e 1960, com destaque para a mudança de hábitos e comportamentos; a intervenção militar em 1968 e o processo de reabertura política em 1984. Esses movimentos e acontecimentos históricos influenciaram o olhar do fotógrafo José Dias Herrera e sua história de vida, mas simultaneamente foram condicionados por ele, na medida em que sua câmera contribuiu para construir a visão que a opinião pública santista formou a propósito deles.

Desse modo, os capítulos no seu conjunto visam compreender o olhar de Herrera sobre o contexto, a época e a cidade, assim como, explicitar sua perspectiva sobre a atividade de fotógrafo, tendo em vista seu repertório cultural e sua bagagem técnica e profissional. E ainda, explicitar os condicionantes do seu olhar, considerando as transformações da técnica fotográfica, a evolução do fotojornalismo no Brasil e da linguagem jornalística, além dos imperativos e necessidades impostos 
pelos acontecimentos históricos que pontuam a trajetória de Herrera (Ditadura Vargas, Segunda Guerra Mundial, Ditadura Militar etc.).

No capítulo 1, enfocamos todo o processo de urbanização e as transformações sociais que converteram Santos de arrabalde colonial em moderna e cosmopolita cidade portuária. A modernização foi alavancada pela riqueza gerada com o monopólio das exportações pelo porto de Santos. Ressaltamos também, os aspectos políticos, em particular a tradição de lutas, desde a abolição da escravatura, na segunda metade do século XIX, até as grandes greves das categorias portuárias, tendência que constitui um dos elementos fundamentais de identificação entre a cidade e seus habitantes. É esse perfil moderno, essa identidade, dada pelo cosmopolitismo e as lutas sociais, de que Santos foi palco que, em grande parte, servem de pano de fundo para a produção de Herrera.

No capítulo 2, enfocamos a maneira como o fotógrafo vê sua prática do fotojornalismo, o modo como ajudava a construir a notícia, o cotidiano na redação dos jornais numa época em que nem pauta havia, sua relação com a técnica fotográfica e sua perspectiva sobre os objetos que fotografou. Procuramos evidenciar a percepção do fotógrafo sobre as realidades retratadas ao longo de seus 70 anos de atividade fotojornalística (as transformações da cidade, os grandes dramas políticos, a mudança de hábitos e costumes etc.).

No capítulo 3, analisamos uma iconografia selecionada do acervo Herrera. Essa seleção permite aprofundar o panorama da história de Santos, com diversas informações que possibilitam contextualizar as imagens. Conforme a metodologia adotada, dividimos o acervo selecionado em temas e analisamos pormenorizadamente uma imagem por tema cada grupo de três a cinco imagens, contrapondo essas imagens a depoimentos do fotógrafo e pesquisa em jornais e 
outras fontes. Essa seqüência de análises torna possível cartografar o cotidiano de Santos e dos santistas, mas também caracterizar melhor o olhar do fotógrafo, sua perspectiva própria sobre sua época e a cidade.

Esta dissertação constitui uma primeira incursão num acervo importante e ainda não pesquisado sistematicamente. Esperamos que desperte o interesse de outros pesquisadores e os motive a se debruçarem também sobre este acervo que aguarda por outros estudos. Pensamos que traçar a trajetória pessoal e profissional de um fotógrafo como José Dias Herrera constitui tarefa importante tanto para a história da fotografia no Brasil, como para a história da cidade de Santos. Nos seus 70 anos de atuação profissional, ele constituiu uma memória visual da cidade de Santos que precisa ser resgatada e disponibilizada para o público, contribuindo para enriquecer a memória da cidade e a história do fotojornalismo no Brasil.

Neste sentido, e considerando os resultados obtidos através desta pesquisa, elencamos a seguir três propostas de utilização do acervo Herrera numa política pública. Acreditamos que é responsabilidade das instituições públicas na área de cultura a preservação e difusão da memória e do patrimônio comum de todos.

Uma primeira proposta é a realização de uma retrospectiva individual da trajetória de Herrera, na forma de uma exposição de fotos, acompanhada de painéis com textos de contextualização das imagens e trechos de depoimentos de Herrera ou sobre ele. Os blocos da exposição poderiam partir daqueles apresentados nesta dissertação. Sugerimos os seguintes blocos: 1. Modernidade santista; 2. Personalidades; 3. Carnaval; 4. Porto; 5. Cultura; 6. Pelé.

Outra proposta é a confecção de um vídeo-documetário, de aproximadamente 50 minutos de duração, com depoimentos de Herrera sobre seu próprio trabalho como fotógrafo e sobre a cidade de Santos. O objetivo seria montar uma narrativa 
audiovisual de caráter simples e didático, que poderia ser exibida ao público em escolas e instituições públicas, por exemplo. Recentemente, foi realizado um curtametragem sobre Herrera, apresentando brevemente a sua biografia. ${ }^{360}$ documentário aqui proposto teria maior duração e enfocaria muito mais o olhar do fotógrafo sobre a cidade e sua história, procurando um nível de profundidade maior do que o de um curta-metragem.

Por fim, a terceira proposta de utilização do acervo Herrera é o Arquivo Virtual José Dias Herrera, que poderia ser hospedado no site da FAMS ou da Prefeitura Municipal de Santos. O arquivo seria composto de fotos de Herrera, acompanhadas de legendas e de breves textos de contextualização dessas imagens. Esse arquivo virtual seria alimentado constantemente, na medida do avanço do processo de organização de seu acervo.

Por fim, cumpre referir aqui as iniciativas em curso para a organização do acervo de Herrera na Fundação Arquivo e Memória de Santos, implicando ações visando a catalogação e a sistematização das imagens. Em 2007, a FAMS foi selecionada, entre instituições do mundo todo, pelo Programa de Desarollo de Archivos Iberoamericanos (ADAI) da Espanha, para o desenvolvimento do projeto Organização, Conservação e Divulgação do Fundo José Herrera. Na verdade, todas essas propostas só serão viáveis na medida em que for feita essa organização do acervo Herrera. Há várias instituições públicas enfim, que poderiam encampar essas iniciativas com recursos próprios, ou com verbas provenientes de leis municipais e federais de incentivo à produção cultural.

\footnotetext{
360 Cabe lembrar aqui que, em 2007, Herrera foi homenageado com um documentário intitulado "Herrera: o homem por trás da lente", que participou do 5ํF Festival Santista de Curtas -Metragens.
} 
Acreditamos que estas seriam três formas apropriadas e viáveis que contribuiriam para divulgar e valorizar o rico trabalho de José Dias Herrera, tornando-o acessível a um público mais amplo. 


\section{Referências Bibliográficas}

ALVEZ, Caleb Faria. Benedito Calixto e a Construção do Imaginário Republicano. Bauru: Edusc, 2003.

ANDRADE, Wilma Therezinha F. Um pouco da história da Baixada Santista. Santos: Leopoldianum, Cadernos de Ecologia humana, n. 4 (1989). . Presença da engenharia e arquitetura -

Baixada Santista. São Paulo, Nobel, 2001. - Santos - Um encontro com a História e

Geografia. Santos: Leopoldianum, 1992.

AFONSO, Cíntia Maria. A paisagem da Baixada Santista. Urbanização, transformação e conservação, São Paulo: Edusp-Fapesp, 2006.

ARAÚJO Filho, José Ribeiro. A expansão urbana de Santos, in: A Baixada Santista: Aspectos geográficos, São Paulo: Edusp, 1965.

BARBOSA, Gino Caldatto. O palácio do café, São Paulo: Magma Cultural Editora, 2004.

- Santos e seus Arrabaldes. Álbum de Militão Augusto de Azevedo, São Paulo: Magma, 2004.

BARTHES, Roland. A Câmara Clara, Rio de Janeiro: Nova Fronteira, 1984. . "A mensagem fotográfica", in: O óbvio e o obtuso: ensaios críticos III. Rio de Janeiro: Nova Fronteira, 1990.

BEIGUELMAN, Paula. Morros santistas, Sociologia, no 10 (1945).

BENJAMIN, Walter. "A obra de arte na era da sua reprodutibilidade técnica" (1935/1936). In: Magia, Técnica, Arte e Política: ensaios sobre literatura e história da cultura - Obras Escolhidas, vol. I. São Paulo: Brasiliense, 1993. 
BERNARDINI, Sidney Piochi. Os planos da cidade: as políticas de intervenção urbana em Santos - de Estevan Fuertes a Saturnino de Brito (1892 - 1910). Rima, 2006.

BOSI, Ecléa. Memória e sociedade. Lembranças de velhos. São Paulo: Companhia das Letras, 1994.

BREFE, Ana C. F. e MOREL-DELEDALLE, Myriame. O Monumento aos Andradas, Santos: Fundação Arquivo e Memória de Santos, 2005.

BRITO FILHO, José Cláudio Monteiro de . Direito Sindical: Análise do Modelo Brasileiro de Relações Coletivas de Trabalho a Luz do Direito Comparado. LTR, 2000

BURKE, Peter, Testemunha Ocular: história e imagem. São Paulo: Edusc, 2004.

CERQUEIRA, Rita Márcia Martins et alii. Santos na formação do Brasil: 500 anos de história, Santos: Prefeitura Municipal de Santos, 2000.

COSTA, Helouise e SILVA, Renato Rodrigues da. A fotografia moderna no Brasil, São Paulo: Cosac \& Naif, 2004.

DUBOIS, Philippe. O ato fotográfico e outros ensaios, Campinas: Papirus, 2003.

FERREIRA, Marieta de Moraes et alii. História Oral. Desafios para o século XXI, Rio de Janeiro: Fiocruz, 2000.

FERREZ, Gilberto. A Fotografia no Brasil / 1840 -1900. 1985

FONTES, Alice Aguiar de Barros. Prática abolicionista em São Paulo: os caifases (1882-1888), Mestrado, São Paulo: USP/FFLCH, 1976, 161 p.

FREITAS, Sônia Maria de. História Oral. Possibilidades e procedimentos, São Paulo: Humanitas-Imprensa Oficial, 2002. 
GITAHY, Maria Lúcia C. Ventos do Mar: Trabalhadores do Porto, movimento operário e cultura urbana em Santos, 1889-1914, São Paulo: UNESP/Prefeitura Municipal de Santos, 1992.

GIRAUD, Laire José. Transatlânticos em Santos, Santos: Gráfica Guarani, 2001. . et alii, Memórias da Hotelaria Santista, São Paulo:

Páginas \& Letras Editora e Gráfica, 1997.

GONÇALVES, Adelto. Barcelona Brasileira. Publisher Brasil, 2002 HONORATO, Cezar. O polvo e o porto. A Cia. Docas de Santos (1888-1914), São Paulo-Santos: Hucitec-Prefeitura Municipal de Santos, 1996.

JúNIOR, Bandeira. História do Carnaval Santista. Santos: A Tribuna, 1974.

KOSSOY, Boris. Realidades e ficções na trama fotográfica, Cotia: Ateliê, 2002. . Hercules Florence, 1833: a descoberta isolada da fotografia no Brasil. 3를. Ed. São Paulo: Edusp, 2006. . Fotografia e História, 2ª . ed. rev., São Paulo: Ateliê Editorial, 2001.

. Dicionário Histórico-Fotográfico Brasileiro: fotógrafos e ofício da fotografia no Brasil (1833-1910). São Paulo: Instituto Moreira Salles, 2002. . Os Tempos da Fotografia: o Efêmero e o Perpétuo. São Paulo: Ateliê Editorial, 2007. . Militão Augusto de Azevedo e a documentação fotográfica de São Paulo (1862-1887): recuperação da cena paulistana através da fotografia, Dissertação (Mestrado em Sociologia), São Paulo: Fundação Escola de Sociologia e Política, 1978. 
São Paulo, 1900. Fotografias de Guilherme Gaensly, São

Paulo: Cosmos, 1988.

LANNA, Ana. A transformação urbana: Santos 1870-1920, Revista da USP, no 41 (1999). . Uma cidade na transição. Santos: 1870-1913. São Paulo: Hucitec / Prefeitura Municipal de Santos, 1996.

LA SCALA JUNIOR, Francisco. Justo, uma trajetória de honradez. 2007.

LE GOFF, Jacques. Memória/História. Enciclopédia Einaudi, Lisboa, Imprensa Nacional-Casa da Moeda, 1984.

LOBO, Maurício Nunes. Imagens em circulação. Os cartões postais produzidos na cidade de Santos pelo fotógrafo José Marques Pereira no início do século XX, Dissertação (Mestrado em História), Campinas: Instituto de Filosofia e Ciências Humanas da Universidade Estadual de Campinas, 2004.

MADRE de DEUS, Frei Gaspar. da. Memórias para a história da capitania de São Vicente, São Paulo: Martins Fontes, 1953.

MARQUES, Nelson Salasar. Imagens de um mundo submerso, 1995

MEIHY, José Carlos S Bom. Manual de história oral, São Paulo: Loyola, 1996.

MELO, Lídia Maria de. Raul Soares, um navio tatuado em nós. São Paulo: Pioneira, 1995.

MONTEIRO, Paulo Gonzalez. A Conquista da Serra do Mar. São Paulo: Ecovias dos Imigrantes S.A., 2002.

MORAIS, Fernando. Olga, São Paulo: Companhia das Letras, 1993.

PETRONE, Maria T. Shorer, O imigrante e a pequena propriedade (18241930), São Paulo: Brasiliense, 1984. 
PRADO Jr, Caio. Evolução Política do Brasil e outros estudos, São Paulo: Brasiliense, 1958.

RODRIGUES, José e PASCOAL, José, Porto de Santos - uma década de transformações (1990-1999), Santos: Núcleo de Pesquisas e Estudos SócioEconômicos-Nese/Unisanta, 2001.

RODRIGUES Olao, Almanaque de Santos - 1969. Banana pra dar e vender... Santos: Gráfica OSM, 1969.

. Veja Santos: Santos, 1975.

. Cartilha da História de Santos. 1980.

. História da Imprensa em Santos, Santos: A Tribuna, 1979.

ROSSINI, José Carlos. Sinistros Marítimos - Costa do Estado de São Paulo / 1900-1999, Santos: edição do autor, 2000.

SAMAIN, Etienne (Org.). O Fotográfico, São Paulo: Hucitec-Senac, 2005.

SANTOS, Francisco Martins dos, e LICHTI, Fernando Martins. História de Santos/Poliantéia Santista, São Vicente: Caudex, 1986.

SANTUCCI, Jane. O dia em que as roletas pararam, Revista Nossa História, no 35 (2006), pág. 36-42.

SARTI, Ingrid. Porto vermelho. Os estivadores santistas no sindicato e na política:São Paulo, Paz e Terra, 1981.

SILVA, Fernando Teixeira da. A carga e a culpa. Os operários das Docas de Santos: Direitos e cultura de solidariedade 1937-1968, São Paulo-Santos: HucitecPrefeitura Municipal de Santos, 1995.'

SILVA, Ricardo Marques da, Sombras sobre Santos: o longo caminho de volta, Santos: Secretaria Municipal de Cultura, 1988.

SONTAG, Susan. Ensaios sobre a fotografia, Rio de Janeiro: Arbor, 1981. 
SOUSA, Jorge Pedro. Uma história crítica do fotojornalismo ocidental, Chapecó: Argos, 2004.

TAVARES, Rodrigo Rodrigues. Moscouzinha Brasileira - cenários e personagens do cotidiano operário de Santos. Humanitas, 2007.

THOMPSON, Paul. A voz do passado. História Oral, São Paulo: Paz e Terra, 1992.

TURAZZI, Maria Inez. Poses e Trejeitos - a Fotografia e as Exposições na Era do espetáculo (1839 -1889). Rocco, 1995.

VASQUEZ, Pedro Karp. Fotógrafos alemães no Brasil do Século XIX. Metalivros, 2000.

VENEZIANO, Neyde. O tempo de revista. In: O Teatro através da história. Rio de Janeiro: Centro Cultural Banco do Brasil, 1994, p.154 e 155.

VILAS BOAS, Sérgio, Santos: o centro histórico, o porto e a cidade, São Paulo: Audichromo Editora / Horizonte Geográfico, 2005.

WAINER, Samuel. Minha Razão de Viver, Rio de Janeiro: Record, 1990.

\section{Outras fontes:}

DEPOIMENTOS de Maria Dias Herrera, 01/09/2007 DEPOIMENTO de Fuensanta Herrera, 01/09/2007 DEPOIMENTO do jornalista Clóvis Galvão, 03/02/2007 DEPOIMENTO do jornalista Lauro Tubino, 15/08/2006. DEPOIMENTO do jornalista Hamleto Rosato, 25/08/2007. DEPOIMENTO da jornalista Miriam Guedes, 05/04/2007. 
DEPOIMENTO do próprio fotógrafo José Dias Herrera, entre os anos de 2004 e 2007.

PALESTRA da prof ${ }^{\mathrm{a}}$. Wilma Therezinha Fernandes de Andrade, proferida em 25 de agosto de 2005, sobre o Centenário dos Canais.

COSIPA. Relatório Anual, 2003.

Revista Veja ․ $^{1235,13 / 05 / 1992}$

Revista Commercial, 26/04/1858.

Revista Commercial, 13/05/1865.

Revista Commercial, 23/07/1861.

Revista Commercial, 09/01/1862.

Coliseu volta a encantar. Revista Beach \& Co, março de 2006, p. 8, 9 e 10.

Jornal Folha de São Paulo, 13/10/1968.

Jornal A Tribuna, 29/11/1959.

Jornal A Tribuna, 01/08/1982.

Jornal $A$ Tribuna, 9/4/1998. caderno especial Cubatão 49 anos.

Jornal $A$ Tribuna, 3, 10, 17, 24 e 31/12/1992. Série especial "Rota de Ouro e Prata".

Entregue ao trânsito, na manhã de ontem, a primeira via do túnel do Monte Serrat. A Tribuna, 07/09/1954, p.24.

Iluminados, com luz fluorescente, foram entregues ontem os dois túneis. $A$ Tribuna, 24/12/1955, p.16.

Manifestação a Geisel na Baixada. A Tribuna, 22/07/1978, p.01.

Via Anchieta, estrada-marco da grandeza de São Paulo, a glorificar a memória do jesuíta lendário. A Tribuna, 23/04/1947, p.3.

No Morro do Marapé, 22 mortes. A Tribuna, 03/03/1956, p..3. 
Acontecimento exponencial na vida de Santos. A Tribuna, 03/07/1945, p.5 e 6. Irmão benemérito. A Tribuna, 07/08/1962, p.9.

Lágrimas sentidas. A Tribuna, 29/08/1961, p.1.

Todo o mundo comenta a renúncia do presidente Jânio Quadros. A Tribuna, 27/08/1961. p.1.

Jânio Quadros morre em SP aos 75 anos. A Tribuna, 17/02/1992. p. A7, A8 e A9.

Eleito prefeito municipal de Santos 0 eng ${ }^{\circ}$ Luiz la Scala Júnior. A Tribuna, 28/03/1961, p.1.

Justo renuncia: vem intervenção. A Tribuna, 29/03/1969, p.1.

Em Santos o dr. Washington Luiz. A Tribuna, 9/7/1953, p.7.

A primeira greve depois de 1964. A Tribuna, 18/03/1980.

América latina: o maior mercado automobilístico. A Tribuna, 25/7/1953, p.5.

A cidade nunca viu algo semelhante. A Tribuna, 10/01/1967, p.24.

Santistas deverão ter gás natural em um ano. A Tribuna, 28/7/2006, p. A4.

As praias de Santos sem jogo - havia ontem por toda a parte uma atmosfera de melancolia e tristeza. A Tribuna, 03/05/1946, p.14.

A Tribuna homenageia Anselmo Duarte. A Tribuna, 05/07/1962, p.1.

Cacilda Becker e Paulo Autran dão nomes a espaços do Coliseu. A Tribuna, 16/10/2007, p.D4.

Aniversário: Quanta saudade!. A Tribuna, 27/1/2006, p.A3.

Recanto onde vivem a fé e a tradição de séculos. A Tribuna, 31/05/1953, p.24.

Rei Momo foi o mesmo por 41 anos. A Tribuna, 26/02/2006, p.A5.

Corso da Brotolândia. A Tribuna, 03/03/1965, p.20. 
Bananas: 1 milhão a menos de cachos exportados. A Tribuna, 11/08/1963, p.24.

A despedida de um velho barco que foi de guerra. A Tribuna, 8/7/1973.

A Avenida Ana Costa. Boqueirão News, 12 e 13/02/2000, p.4. coluna Almanaque Santista.

Os Casarões do Valongo. Boqueirão News, 23 e 24/08/2003. p.4. coluna Almanaque Santista.

Sinal verde para o projeto no Emissário. Jornal da Orla, 18 e 19/08/2007, p.9.

O gol definitivo. Jornal da Orla, 25 e 26/08/2007, p. 4 e 5.

A homenagem de Santos a Esmeraldo Tarquínio. Jornal da Orla, 14 e 15/4/2007, p.2.

Bem perto das grandes armas. Jornal da Orla, agosto de 2005.

Praça da Independência é entregue hoje à população. Diário Oficial de Santos, 2/9/2000, p.4.

Novo Aquário com espaço triplicado será entregue nesta quinta-feira. Diário Oficial de Santos, 25/1/2006, p.3.

Túnel será totalmente recuperado, Diário Oficial de Santos, 24/05/2006, p.6.

Paulo Autran e Cacilda Becker terão nomes eternizados no Coliseu, Diário Oficial de Santos, 17/10/2007, p.20.

Hotel Parque Balneário. Diário Oficial de Santos, 28/05/2004, p.2. coluna Memória Santista.

Paço Municipal. Diário Oficial de Santos, 10/10/2003, p.2. coluna Memória Santista.

Santos e o Golpe de 64. Diário Oficial de Santos, 16/4/2004, p.2. coluna Memória Santista. 
Bolsa do Café completa 85 anos. Diário Oficial de Santos, 07/09/2007, p.12.

Prefeitura compra Teatro Guarany. Diário Oficial de Santos, 30/06/2003, p.16.

De volta à folia: Santos retoma os desfiles. Jornal Perspectiva, fevereiro de 2006, p.5.

Jornal dos Jornalistas, $n^{\circ}$ 273, abril de 2005.

Revista Nossa História, n²1, 2005. p.66. , n³5, 2006. pp.36-42.

PREFEITURA MUNICIPAL DE SANTOS. Emissário Submarino. Disponível em: http://www.santos.sp.gov.br/frames.php?pag=/comunicacao/historia/historia.html

IVAMOTO, Henrique Seiji. A Fundação da Misericórida e do Hospital. Disponível em: http:www.scms.org.br/historia

FUNDAÇÃO MÁRIO COVAS. Perfil de Mário Covas. Disponível em: http://www.fmcovas.org.br/mariocovas/

PRODESAN. Limpeza Pública. Disponível em: http://www.prodesan.com.br/opencms/opencms/system/modules/br.com.prodesan/js p/paginadepto.jsp?subFolder=/Prodesan/aempresa/areasdeatuacao/lp/

SANTOS FUTEBOL CLUBE. Biografia de Pelé. Disponível em: http:// santos.globo.com/clube_historia?pbiografia 
ANEXOS 
ANEXO A - Modelo de ficha iconográfica

Tipo: (x) Negativo ( ) Foto avulsa

Identificação: H.02.03

Data: 1964

Estado de conservação:

(x)Bom ( ) Regular ( ) Péssimo

Tamanho/formato: $24 \times 36$

Veículo onde foi publicada:

( ) O Diário (x)A Tribuna ( ) O Cruzeiro ( ) Outro

Finalidade: Reportagem para o jornal

Assunto: Política, Porto

Legenda: ( ) Atribuída (x ) Original

Interior do navio Raul Soares. Porto de Santos, 1964

Descrição: Vista do convés do navio-presídio Raul Soares com cerca de 37 presos enfileirados para a visita da imprensa e dos militares.

Observações e notas: O navio Raul Soares chegou ao Porto de Santos a 24 de abril de 1964 e, ancorado junto a llha Barnabé, foi utilizado como prisão de acusados de crimes políticos pelas autoridades do regime militar de maio a outubro de 1964. Palco de torturas físicas e psicológicas, tornourse um dos símbolos da repressão em Santos. Antes de ser transformado em prisão, o Raul Soares, antigo transatlântico alemão, adquirido pelo Lloyd Brasileiro em 1925, havia transportado os pracinhas da FEB aos campos de batalha na Europa, para lutar contra as forças do Eixo. Nada mais resta do velho navio. Suas chapas de aço foram desmontadas e viraram sucata. 
ANEXO B - Entrevista com José Dias Herrera, no dia 14 de setembro de 2005.

\section{De onde é a sua família:}

Meus pais eram espanhóis. Eu e a minha irmã mais velha nascemos em São Paulo, e os meus outros irmãos já são santistas. Casei com uma santista e vivo em santos até hoje. Tive duas filhas, que são santistas. Uma mora em Campinas e a outra está morando nos Estados Unidos. Tenho cinco netos e uma bisneta.

\section{Vocês são em quantos irmãos?}

Éramos cinco irmãos: três homens e duas mulheres. Dos homens, eu era o mais velho. Eles eram bonitos, fortes; eu era o mais franzino, mais feinho, mais desajeitado... E, no fim, eu sou o único vivo. É a vida, né?... Mas, minhas duas irmãs continuam vivas.

\section{Onde o senhor morou aqui em Santos?}

Morei em vários lugares, quase sempre no bairro do Campo Grande. Conforme a vida foi melhorando, a gente foi mudando de casa. Morei na Rua Marquês de São Vivente quando eu era criança, depois fui para a Avenida Bernardino de Campos, $n^{\circ}$ 19. Quando eu estava no Diário, conseguimos comprar um chalezinho na Rua Evaristo da Veiga. Quando eu casei, voltei para a Rua Marquês de São Vicente, fui morar num bangalô que eu comprei: o $n^{\circ} 50$. Hoje, eu moro na Avenida Vicente de Carvalho, em frente à praia, perto do Canal 3.

\section{Com quantos anos o senhor começou a trabalhar?}

Com uns 10 ou 11 anos. Minha vida de trabalhador começou bem cedo.

\section{Por que o senhor começou a trabalhar tão cedo?}

Como eu era o filho mais velho, o mais responsável, e tinha que ajudar minha mãe porque o meu pai ficou doente quando eu era criança. Ele teve a gripe espanhola e ficou inutilizado por causa de tanto remédio. Minha mãe costurava para fora, mas não recebia o suficiente. Então, eu tive que trabalhar. 
Trabalhei em vários lugares e fiz várias coisas. No começo, trabalhei numa sapataria... Nem lembro mais desse comecinho. Durante a Revolução Constitucionalista de 1932, recolhia metais nas ruas e pedia nas casas. Sabe qual era a nossa missão? Juntava cinco ou seis meninos e nós saíamos pelas ruas pra pegar ferro, metais, coisas para fundir e fazer armamento, para ajudar na revolução. A gente via os soldados para lá e para cá e a gente sabia que era para acabar com a ditadura do Getúlio Vargas. Com uns 13 anos eu fazia entregas de mercadorias para a Casa Lencke, que era uma casa alemã de artigos de luxo e tecidos. Aí eu tirava um dinheirinho bom porque os fregueses também me davam um trocadinho ou um presentinho. Esse foi praticamente o primeiro emprego certo, que eu tinha que cumprir horário, ir todo dia, tinha função específica. A Casa Lenke ficava no mesmo endereço do futuro jornal O Diário, onde eu trabalharia mais tarde. Rua do Comércio 9, 11, 13 e 15. Interessante não? Depois, eu trabalhei numa casa de molduras chamada Casa Verde, onde eu era ajudante de um parente meu que fazia espelhação. Ajudando no polimento dos espelhos, eu fui adquirindo um conhecimento que eu utilizei na época da Segunda Guerra: fabricar clichês de vidro. Durante a guerra, teve falta de material fotográfico por causa da interrupção das importações e isso me ajudou bastante porque fabriquei negativos de vidro. Mais para frente, eu fui para o restaurante da Alfândega, já tinha uns 14 anos. Lá eu fazia de tudo: lavava louça, servia as pessoas e os funcionários da Alfânfega, preparava pratos simples como uma verdura e um legume.

\section{Quando e como foi o seu primeiro contato com a fotografia:}

Eu fui trabalhar numa casa de artigos fotográficos quando eu estava com 14 anos. Daí, logo comecei a arranjar serviços avulsos e larguei a loja. Como todos os empregos anteriores, a fotografia surgiu na minha vida por necessidade e acabou ajudando toda a minha família.

\section{O senhor começou a fazer serviços de fotografia quando exatamente?}

Eu comecei a tirar fotografia com 15 anos; fazia trabalhos avulsos como autônomo para jornais, para algumas pessoas que me conheciam, fazia casamentos, aniversário... Antes do Diário, eu já fotografava. 
Não. Eu já tinha trabalhado em outros lugares, fazendo outras coisas. Mas, quando calhou de fazer fotografia, eu fiquei só na fotografia. Pra mim, a gente tem que se dedicar ao que faz para sair bem feito; não dá pra ficar fazendo várias coisas ao mesmo tempo.

\section{O senhor começou no Diário com quantos anos?}

Com 17 anos, em 1937. Eu era um adolescente. Foi o meu primeiro emprego oficial, com registro em carteira.

\section{E a sua infância e adolescência? O senhor conseguiu aproveitar?}

Olha, eu tive tanta sorte na vida que, apesar de eu trabalhar muito, várias horas, debaixo de sol e chuva, eu sempre fiz com muito prazer. Quando eu comecei a fotografar eu era mocinho, tinha 15 anos, e aproveitava muito os bailes, os casamentos, os jantares que eu fotografava. Por conta do serviço, eu estava sempre em bons restaurantes, em lugares chiques e, o melhor, sempre de graça. rsrsrsrsrs. Eu dançava com as meninas ricas. Com o tempo, nos jornais e nas revistas, então, as coisas só foram melhorando. Distração não faltava.

\section{E os estudos? Deu para completar?}

Eu parei de estudar na quarta série, com uns 10 anos. Eu tirei diploma do curso primário na escola Barão do Rio Branco, no Campo Grande...

Daí pra frente, foi trabalhar. Eu até queria continuar estudando, mas não dava porque eu tinha que ajudar a minha mãe a sustentar a família.

Eu pensava que nunca seria ninguém porque eu não tinha estudo. Mas, daí, eu conheci a fotografia, comecei a estudar sobre o assunto por conta própria, comprava livros, aprendia a mexer nas câmeras... Nunca tive professor. Felizmente comecei a ganhar dinheiro, a melhorar de vida...

\section{O que a fotografia Ihe proporcionou?}

Tudo: conhecer lugares, pessoas e até a minha esposa, que eu conheci quando fotografava um casamento... E já são mais de 50 anos de casado... E, claro! Ganhei dinheiro, sustentei a minha família... Construí a minha vida com a fotografia, né? Veja bem, quando eu cheguei de São Paulo, com sete anos, minha família não tinha nada; nós viemos para morar num porão da casa de um parente, dormíamos em um 
colchão no chão. Hoje, moro num apartamento de três banheiros, de frente à praia, num dos melhores bairros de Santos, no $13^{\circ}$ andar. E conquistei tudo isso com a fotografia, sozinho. Nem a minha esposa precisou trabalhar.

\section{Quem mais trabalhou com a fotografia em sua família:}

Os três irmãos homens foram fotógrafos. Eu comecei o ofício e os ensinei depois. $O$ Rafael foi meu ajudante particular no Diário; eu mandava ele fazer os trabalhos mais fáceis. Quando o Nascimento, diretor do jornal A Tribuna, me ofereceu emprego no jornal e eu não aceitei porque as vantagens não eram tão boas como no Diário, eu indiquei o Rafael. O Rafael foi se dando bem lá na Tribuna e o meu outro irmão, o Paco (Francisco), começou a se interessar por fotografia também. De repente, estávamos os três atuando como fotógrafos.

\section{Em que veículos o senhor trabalhou?}

No jornal O Diário, na Tribuna e agora no Diário Oficial. Também fazia trabalhos para a Folha de São Paulo, Estadão, para revista O Cruzeiro...

\section{Para que editorias o senhor trabalhou, no Diário e na Tribuna?}

No Diário, trabalhei para todas as editorias, pra tudo... Os assuntos relacionados à polícia eram mais comuns. Eu tinha sempre um cadáver ou um delegado para fotografar. Acidentes e desabamentos de morros também eu fazia bastante pro Diário... É que o Diário era um jornal bastante popular, sempre publicava essas matérias mais direcionadas ao povo. Na Tribuna, também fiz de tudo, mas, principalmente, Porto e Esportes.

\section{O senhor trabalhou com outros fotógrafos?}

No Diário tinha o Justo Perez. Na Tribuna, trabalhavam o José Silvério Bomfim e o Pedro Peressin, mas eu era o único registrado. Para entrar na Tribuna, eu exigi registro, salário fixo e laboratório montado... Por isso, eu não fui antes.

\section{O que o senhor mais gostava de fotografar?}

Eu não tenho dessas. Sempre gostei de tudo: esporte, social, porto, política, policial... Pra mim era tudo igual. Eu gostava de fotografar, principalmente quando me rendia um dinheiro bom. 


\section{Na sua opinião, qual a foto mais fácil de se fazer?}

Todas as fotos eram fáceis. Na verdade, por mais difícil que ela fosse, era fácil porque eu sempre fiz com amor. Então, não tinha problemas, só prazer.

\section{O senhor viajou muito a trabalho?}

Nossa! Viajei demais. Fui pra São Paulo, pro interior, litoral... e pro exterior também.

\section{No Diário, o senhor costumava viajar para aonde?}

No Diário, eu fazia mais as viagens para os litorais sul e norte. Era uma dificuldade tremenda. Não tinha estrada, não havia condução, só dava pra chegar de trem. E, quando chovia, o trem parava e nós tínhamos que procurar alguma casa próxima e esperar a chuva passar.

\section{Nós quem?}

Eu e o jornalista que me acompanhava de vez em quando. Nós ficamos hospedados nas casas dos moradores daquelas cidadezinhas, que não tinham nada. Os moradores valorizavam bastante o nosso trabalho porque a gente fazia reportagens sobre as dificuldades de acesso, de locomoção. As nossas matérias tinham como objetivo melhorar a vida e a condição das pessoas daquele fim de mundo, e elas ficavam agradecidas... Conversavam com a gente, davam alojamento, comida, acompanhavam a alguns lugares... $\mathrm{O}$ engraçado é que sempre comentavam que, indo pro Litoral, eu pelo menos comeria bastante banana. Que nada!!! Não existia banana coisa nenhuma. O que tinha estava tudo verde, nunca madura... porque eles cortavam tudo verde para exportar e fornecer para região, nem esperavam amadurecer porque poderia estragar, né?

\section{E para o interior, outros estados e países?}

Também ia para São Paulo e para o interior. Mas no Diário nunca saí do Brasil.

\section{E na Tribuna?}

Aí eu viajei demais. Por causa do Santos Futebol Clube eu viajei o mundo inteiro. 
ANEXO C - Entrevista com José Dias Herrera no dia 01 de março de 2006.

\section{O que fez do senhor um bom profissional?}

Disciplina, boa vontade, correr atrás da notícia, não se envolver com os casos e as pessoas fotografadas... e coragem. Eu lembro que trabalhava no Diário e teve uma ocasião que eu precisava fotografar uma jogatina que acontecia em frente ao Hotel Internacional, no José Menino, que acontecia ao ar livre e era proibido. As bancas ficavam na rua mesmo e atraía muita gente, turistas... Era um caso sério!. Quando eu cheguei lá, não queriam deixar eu fotografar e os seguranças falaram que se eu tirasse iriam me bater, quebrar a minha máquina. E eu disse: Então pode começar porque eu vou tirar, é o meu trabalho. Vocês fazem o que o patrão manda e eu também. Eu subi numa cadeira e tirei, e não me fizeram nada... Vieram os homens da jogatina conversar comigo com muita educação e explicar que aquilo era o ganha-pão deles. Eu falei que estava cumprindo ordens e sugeri que eles fossem direto lá no secretário do Diário pedir para que a foto não fosse publicada. Só sei que a foto não saiu no jornal, mas eu tirei, cumpri o meu papel.

\section{Quais as máquinas que o senhor utilizou ao longo da sua carreira?}

Comecei com uma câmera alemã chamada Voigtlander, que não era profissional, era amadora mesmo. Comprei usada e usei pouco tempo, mas eu gostava. Não tinha outra, então eu tinha que gostar.

Depois, tive duas Speed Graphic, de fabricação americana. Comprei novas em São Paulo. Elas eram grandes e pesadas, mas muito boas... Foi com uma delas que eu fotografei o ex-presidente Washington Luis quando ele esteve no Guarujá, logo quando voltou do exílio.

Depois comprei a Rolleiflex, que eu considero ideal para trabalhar em jornal e fotografar casamentos por causa dos seus negativos grandes... aqueles quadrados, $6 \times 6 .$. Quando eu preciso de mais esmero, de ampliações maiores, eu uso ela... Em casamentos, só usava a Rolleiflex... Ganhei muito dinheiro trabalhando com ela, tenho milhares de negativos dela; foi a que mais usei em toda a minha carreira... Hoje, estou com a minha terceira Rolleiflex. Daí, veio a Nikon, da qual tive três também... Excelente!!!... São aquelas dos negativos mais atuais, 35mm... Hoje, é a que mais uso, principalmente para serviços particulares. Ainda tenho algumas 
dessas máquinas em casa sim... Ah! Cheguei a experimentar a tal Hasenblade, que é sueca, mais específica para fotos panorâmicas. Mas, achei ruim, muito pesada.

\section{Qual máquina o senhor mais gostava?}

Sempre gostei de todas as minhas máquinas... A gente não desgosta da máquina, o que acontece é que você vai usando e vai mudando, trocando por outra que te facilita mais o trabalho... Mas, nunca desgosta.

\section{O que o senhor acha das máquinas digitais?}

Isso acabou com os fotógrafos. Agora, qualquer pessoa pega uma maquininha digital dessas e faz fotografia. O fotógrafo oficial não é mais chamado para fazer serviços particulares. Antes, o fotógrafo fazia qualquer serviço e ganhava um dinheirinho bom. Agora, o negócio está difícil. Hoje, está tudo muito simples, não precisa calcular distância, luz, foco... A profissão perdeu o valor.

\section{Quais os cuidados que o senhor tem com o seu acervo?}

Nenhum. Eu vendi alguma coisa pra Fundação Arquivo e memória e pro Pelé. Vendo também uma foto aqui e outra ali para algum interessado. A maior coisa que eu lamento é de não ter anotado nada sobre as fotos, de não ter me preocupado em organizar o meu trabalho...Eu nunca imaginei que fosse precisar recordar acontecimentos de 70 anos atrás. Não pensei que ia viver tanto...

\section{Qual a diferença do profissional fotógrafo de hoje e o profissional de antigamente, de quando o senhor começou a fotografar?}

O profissional de antigamente não existe mais. Hoje existe uma tecnologia que a gente nunca imaginou que pudesse existir e que está acabando com a profissão de fotógrafo. Com a câmera digital todo mundo acha que sabe fotografar, mas ninguém sabe nada. A foto artística está perdendo o valor. Antes, o fotógrafo tinha que saber ajustar luz e velocidade na máquina. Hoje, um botão faz tudo e nem mais de filme precisa. Tanto uma criança que não tem nem tamanho como um idoso de 80 anos que nunca tirou uma foto está fotografando. Hoje, o homem não comanda a máquina, a máquina se comanda sozinha. $\mathrm{E}$ assim, tão tirando o serviço do profissional... Para você ter uma idéia, antigamente, quando o lugar tinha muita 
gente e era muito escuro, era necessário colocar a máquina no tripé e dar a explosão de magnésio pra clarear o ambiente.

Quando o senhor ingressou no Diário, e depois na Tribuna, o que eles exigiam?

Profissionalismo. Eu precisava provar todo dia que era bom, não existia uma foto impossível pra mim. Eu tinha que seguir um estilo jornalístico diferente para cada assunto. Hoje, não existe mais esse tipo de cobrança. Antigamente, tirávamos foto de tudo, tínhamos que estar em todos os lugares, tínhamos que produzir sempre fotos atuais... Era trabalho duro mesmo. Hoje, tiram uma foto rapidinho ou até usam imagem de arquivo...

O senhor acha que a profissão de fotógrafo hoje é mais discriminada do que era antigamente?

A palavra não é discriminação, é abandono. Hoje os fotógrafos estão abandonados. Ninguém mais contrata aquele fotógrafo profissional, principalmente para festas e eventos. Qualquer um compra uma super máquina e se diz fotógrafo... e quando vai oferecer os seus serviços mostra a tecnologia que a máquina oferece; não precisa de prática... O fotógrafo de verdade, que produz a foto artística, está acabando...

\section{Como era ser repórter fotográfico na época em que o senhor trabalhava nos jornais?}

Os fotógrafos faziam de tudo, eram responsáveis por todo o processo da fotografia. Quando eu comecei, eu trabalhava numa casa comercial de artigos fotográficos e ficava testando várias máquinas para ver com qual eu me adaptava melhor. Lá, eu vendia máquinas e filmes, revelava, ampliava, fazia de tudo... Quando eu resolvi partir para a fotografia mesmo, eu comprei um modelo usado porque, além de não ter dinheiro, eu precisava fotografar um pouco para ver se tinha jeito para a profissão... porque o resto (revelar, ampliar etc) eu já sabia fazer mais ou menos...

Mas, como era o trabalho de um repórter fotográfico na época em que o senhor estava no Diário, por exemplo? Era simplesmente fotografar? 
Que nada!!! Quando eu comecei no Diário, era um trabalho pior do que de estivador, trabalhando a qualquer hora do dia ou da noite, debaixo de sol quente ou chuva, subindo em morro..., tinha que por a máquina no tripé... Era uma barbaridade.

\section{O senhor saía pautado para as ruas?}

Na maioria das vezes não. Eu chegava na redação, pegava a maquininha e saía pras ruas atrás de assunto, de algum acontecimento que pudesse dar matéria. Eu fotografava buraco de rua, poste de iluminação quebrado, acidentes, brigas; o que aparecesse na minha frente. Daí, eu mesmo pegava as informações, o contato das fontes se necessário e voltava para redação para entregar para o secretário (atual chefe de redação). Tinha dias que eu ia às ruas e voltava pra redação várias vezes... Ou também eu estava sozinho na redação, tocava o telefone lá no jornal e informavam alguma coisa: um incêndio no cais, por exemplo. Eu saía correndo, tirava as fotos, anotava os dados que eu conseguia na hora, passava para o papel e entregava para o secretário...

Naquela época nem tinha pauteiro, não tinha ninguém... Até o próprio secretário chegava na redação às 4 horas da tarde.

\section{Então, o senhor também fazia o papel do repórter mesmo?}

Isso mesmo, eu fiz várias reportagens... Entrevistava as pessoas quando rão tinha ninguém para me acompanhar, pegava os dados... O mais interessante nisso tudo é que eu fui um jornalista muito pobre. O serviço de reportagem escrita me dava prejuízo porque eu tirava muito mais dinheiro com as fotos. Por isso, eu não gostava de perder o meu tempo escrevendo, mas tinha que ser feito, né?

\section{O senhor, então, chegou a escrever matérias inteiras?}

Sim, no Diário. Para a Tribuna eu cheguei a escrever quando fazia trabalhos avulsos pra ela. Quando eu fui trabalhar lá oficialmente, registrado, eu consegui ficar só tirando fotos.

\section{O senhor tinha algum dia de folga?}

Que nada! Eu não tinha nem horário fixo. Trabalhava a qualquer hora: de dia, de noite, de madrugada, de domingo. Não tinha essa história de carga horária... Eu tinha que ir atrás das matérias, dos assuntos... Quantas vezes eu acordei de noite 
escutando explosão, ou briga, ou qualquer coisa e saía, já com a máquina na mão, para averiguar o que era.

\section{O senhor acredita que atualmente o trabalho do fotógrafo é mais fácil?}

Acredito que deve ser. Hoje eles saem já sabendo o que vão fotografar e, além disso, existe muito mais fotógrafo. Então, o trabalho fica mais dividido. No Diário, éramos em dois para fazer tudo. Eu acho que na Tribuna, hoje, são dez ou doze. Aumentou bem, né?

\section{Como era fotografar casamentos?}

Eu era o preferido das noivas; era muito disputado para fotografar casamentos e festas particulares. Além de já ser conhecido por causa do jornal, eu conseguia convencer os padres a me deixar bater uma ou duas fotos dentro da igreja - o que era proibido. O problema era que o magnésio das máquinas fazia uma fumaça danada, que atrapalhava mesmo... Por isso, fotos dentro das igrejas eram proibidas... Mas, eu acabava conseguindo... Eu tirava uma foto da noiva entrando, depois outra do casal no altar, e o resto das imagens eu pegava na porta da igreja, no carro, na festa [...] Eu melhorei de vida com esses serviços. Cobrava bastante dinheiro.

\section{E como era fotografar eventos em hotéis, clubes, teatros e cassinos?}

Nos shows era a mesma coisa, eu não fotografava para não atrapalhar... Quando eu tirava uma ou outra foto lá dentro, durante o show, já me olhavam feio... Então, antes das apresentações, os artistas posavam pra mim, fingiam que estavam encenando para eu bater a foto... Raramente eu fotografava alguma coisa do durante os espetáculos...

Agora, em bailes e festas normais, onde não aconteciam apresentações, eu fotografava normalmente: as pessoas dançando, conversando, comendo... Aí, não tinha problema.

\section{Como era fotografar os morros de Santos?}

Difícil. Naquela época, quase todo dia caía um pedaço de morro, uma casa. Então, eu tinha que subir o morro a pé, não tinha acesso de carro, os caminhos eram 
horríveis. Para descer, tinha que ir bem devagarzinho, senão você caía numa tacada só e ia parar lá embaixo, na avenida.

\section{E para os jornais? Havia fotos produzidas?}

Muitas, e para todas as editorias. Para a página de policial, por exemplo. Quando tinha um crime, lá ia eu no plantão da noite, de madrugada. Eu montava o tripé, com o magnésio, e tirava a foto do cadáver, o delegado examinando o corpo, tudo encenado. Às vezes, quando dava para mexer, eles até colocavam o morto numa posição melhor...

A foto do De Gaulle na Cosipa também foi encenada, lembra? E tantas outras: no Porto, nas ruas mesmo,... os políticos encenavam muito pra mim...

\section{Qual o papel do fotógrafo para a publicação da imagem? O senhor apenas tirava a foto?}

Eu fazia tudo: tirava a foto, voltava para o laboratório do próprio jornal para revelar, pendurava o filme para secar... e isso era demorado, levava mais de uma hora. Enquanto o filme secava, eu saía novamente para fotografar mais coisa. Daí, eu chegava e escolhia quais as imagens mais interessantes para ampliar. Eu ampliava umas três ou quatro e levava para o secretário escolher. As ampliações variavam de tamanho: uma coluna, duas colunas, três colunas, conforme o secretário pedia.... Mas eu sempre sabia, mais ou menos, o tamanho certo, porque eu sabia o tamanho da matéria e calculava... Outra coisa importante é que era eu que comprava todo o material: as drogas, o filme. Eu comprava em São Paulo, pegava a nota e o jornal me reembolsava. O laboratório do jornal também era de minha total responsabilidade, até a limpeza.

\section{Como surgiu a oportunidade de atuar como speaker numa rádio? E como foi essa experiência?}

Isso foi mais uma brincadeira... Eu tinha amizade com a Rosinha Mastrângelo e ela era uma das pessoas que comandava aquilo. E um dia ela precisou de alguém para fazer o programa e fiz pra ela... Eu fiz comercial, entrevistas e até rádio novela... Não tinha ninguém para fazer o papel e eu fiz para quebrar o galho. E eu não ganhava nada, era só por amizade mesmo. 


\section{Em que rádio?}

Fazia pra Rádio Clube de Santos e fiz uma vez na Rádio Atlântica.

\section{Durante quanto tempo o senhor atuou em rádio?}

Não teve tempo, quando precisavam me chamavam... Eu ia mais por diversão mesmo, mas até que fiz bastante coisa.

\section{Quando, para o senhor, o trabalho começou a ficar mais fácil?}

Já na década de 1960. O jornal contratou mais fotógrafos e também um laboratorista. Eu sempre trabalhei muito, o quanto dava para ganhar mais dinheiro.

\section{Mas havia hora extra?}

Não, mas quanto mais eu fotografasse mais material eu teria para vender por fora. $E$ era aí que eu ganhava bastante. As agências (Folha, O Estado) das outras cidades sabiam que eu fotografava e me encomendavam fotos. Eu trabalhava para vários jornais ao mesmo tempo, entende? Eu tinha interesse em produzir sempre muitas fotos porque aí que eu ganhava dinheiro, nos serviços avulsos. Se eu pudesse, eu trabalharia 50 horas por dia, porque cada hora me rendia um bom dinheiro.

\section{Mas, o senhor tinha um bom salário?}

Tinha, muito melhor do que o de hoje. No começo, o salário era bom, motivava o profissional a trabalhar; era um salário que retratava a realidade do momento do país.

\section{Quando o salário começou a ficar defasado?}

A partir da década de 1980. O sindicato começou a apertar, a pegar no pé com carga horária, hora extra. Os jornais passaram a enxugar as redações e no que reduziu a equipe, para não pagar hora extra, inventou folga, outras compensações. E hoje o que existe é um outro jornal, sem qualidade, sem informação. Uma droga!!!

\section{O que aconteceu com os jornais na sua opinião?}

Antigamente, se vendia muito mais jornal, no caso da Tribuna, pelo menos. As reportagens eram de assunto de interesse do povo, todos os dias você tinha que estar nas ruas, nos morros, nos hospitais, nos órgãos da prefeitura, nas escolas. 
Hoje, as matérias são feitas dentro da redação. Como pode? Não fazem mais nada, não cavam notícia, não correm atrás do furo. Eles se pautam pelo o que as assessorias mandam; não ouvem os moradores de uma rua, os problemas e reivindicações de uma parcela da população. 
ANEXO D - Entrevista com José Dia Herrera no dia 31 de maio de 2007.

\section{Quando o senhor começou a fotografar os treinos e jogos do Santos Futebol Clube?}

No comecinho da década de 1940, muito antes de Pelé. Logo que eu entrei no Diário... Conheci a turma toda: Athié, Modesto Roma... todo mundo.

\section{Antes do Pelé aparecer, o time já era bom?}

Claro. Era excelente, um ótimo time! Tinha muitos craques. A sorte do Santos foi que juntou duas coisas formidáveis: o time, que já era muito bom, com o Pelé. Porque, na verdade, o Pelé sozinho não conseguiria ir adiante. Na verdade, o Pelé ficou bom no Santos, quando começou a treinar, a jogar bola mesmo.

\section{O senhor torce para que time?}

Quando eu me conheci por gente eu torcia para o Corinthians porque a minha família era toda descendente de espanhóis e os espanhóis lá em São Paulo eram todos corintianos. Então, eu também peguei a mania de ser corintiano... Nem sabia o que era corintiano nem nada... Quando eu vim para Santos e comecei a trabalhar no Diário, o Santos Futebol Clube virou a minha segunda casa e eu me tornei santista, claro. Todo dia eu acompanhava os treinos, entrevistas, os jogos. E virei santista e sou santista até hoje. E virei santista muito antes de Pelé.

\section{Como era o estádio da Vila Belmiro quando o senhor começou a fotografar o time do Santos Futebol Clube?}

O campo de futebol é praticamente o mesmo: aquele quadrado com a grama, mas a grama hoje tem mais qualidade. Estão sempre arrumando, né? Só que as arquibancadas eram menores e muito bonitinhas; enfeitavam bem o estádio. Para a população da Cidade na época era suficiente, mas com o tempo precisaram ampliar porque já não comportava todo mundo... Tinha trechos de arquibancada de madeira e de cimento. As arquibancadas de madeira pareciam de circo, sabe?

\section{Antes da aparição de Pelé, que jogador o senhor considerava o melhor?}

Não tinha melhor; era um time inteiro de craques. 


\section{O senhor lembra da chegada de Pelé?}

E como não? Fotografei o Pelé logo no primeiro dia dele pisando na Vila Belmiro. Ele chegou de Bauru com a família e precisei providenciar uma camiseta do clube às pressas para poder fotografá-lo. A primeira foto dele com a camisa do alvinegro foi eu quem tirei, e já era a camisa 10. A primeira foto tirada foi com a família, com o pai, a mãe e irmã. Ele sozinho assinando o contrato foi a terceira ou quarta foto tirada.

\section{Quando o senhor começou a viajar com o Santos Futebol Clube?}

Conheci o mundo inteiro viajando com o Santos. No começo, antes de Pelé, eu tarbalhava no Diário e ia acompanhando o time somente para as cidades do interior e para outros estados. Quando o Pelé chegou, daí eu comecei a sair do Brasil... Na Tribuna, eu fui muito para fora, eu conheci vários países: Argentina, Uruguai, Paraguai... França, Espanha, Bélgica, Polônia, Portugal, Itália... Alemanha, Suíça, quase tudo.

\section{E como era fotografar o Santos lá fora?}

Eu fazia as fotos e, quando o jogo acabava, corria para um posto telefônico para passar o resultado aqui pra Tribuna... Muitas vezes, só viajava eu do jornal; nem o repórter ia. Então, eu tinha que fazer tudo. Para bater a foto era muito trabahoso lá fora, principalmente na Europa, porque tudo era proibido: tinha que ter autorização, tinha hora certa, tinha lugar certo para ficar... um lugar horrível... Com o tempo, os problemas e dificuldades foram diminuindo porque o sistema de comunicação foi ficando cada vez mais eficiente... Na época da Tribuna, o repórter Antonio Guenaga, de vez em quando, me acompanhava. Daí, as coisas ficavam mais fáceis.

\section{O senhor cobria o Santos Futebol Clube só para o jornal em que estava trabalhando na ocasião ou vendia as imagens para outros veículos?}

Houve uma época em que eu vendia muita foto para outros jornais. Eu fazia serviços avulsos para Gazeta Esportiva, Folha de São Paulo, O Estado (de São Paulo), O Esporte, para a revista $\mathrm{O}$ Cruzeiro. Eu podia, por exemplo, fazer uma ou duas fotos para o Diário em cinco minutos e ir embora, mas não. Eu acompanhava e fotografava praticamente os jogos inteiros para poder produzir uma grande 
quantidade de fotos para vender. Daí, eu corria para o laboratório, revelava e ampliava tudo e mandava para São Paulo para uma porção de jornais... Os jornais de São Paulo não mandavam fotógrafos para cobrir os jogos do Santos porque sabiam que podiam contar com os meus serviços.

\section{Os seus irmãos também fotografaram o Santos Futebol Clube?}

Sim, nós três cobrimos o Santos. Às vezes, nós nos encontrávamos nos jogos, mas cada um fotografando para um veículo diferente. Às vezes, essas coincidências aconteciam. Inclusive, quando o Pelé chegou no Santos, o meu irmão Rafael também era setorista lá.

\section{Como foi viajar e conviver com o Santos Futebol Clube de Pelé?}

Eu sempre acompanhava o time. Tirava fotos dos treinos, dos jogos e do dia-a-dia dos jogadores lá fora. Estava sempre com eles e eles também faziam questão que eu aparecesse em algumas fotos tiradas nos momentos de passeio, lazer. Ficávamos nos mesmos hotéis, pegávamos o mesmo avião, fazíamos as refeições juntos... Eu era praticamente do time, só não jogava. Eu era de casa.

\section{Quanto tempo o senhor costumava ficar fora?}

Dependia, mas na maioria das vezes as viagens eram demoradas: eu ficava fora de 10 a 15 dias, voltava e, dali a pouco, viajava novamente.

\section{As suas viagens não atrapalharam o seu casamento?}

Não. A Zilda sempre entendeu que eu precisava trabalhar. Além disso, as minhas irmãs faziam companhia pra ela, ficavam direto lá em casa. Nunca tivemos problemas por causa disso... E, bem no começo, quando as viagens começaram, eu ainda era solteiro. Toda a correria mesmo a minha esposa não vivenciou tanto.

\section{Como era a sua relação com o Pelé?}

Eu praticamente me tornei o fotógrafo oficial dele. Por causa da proximidade, eu comecei a fazer fotos particulares para ele. Ele tinha uma firma, um escritório de representações, ou alguma coisa assim, e eu fotografava os produtos que ele negociava...eram fotos comerciais que eu tirava lá no escritório. Fotografei também o 
namoro dele, o casamento dele, quando nasceram os filhos, ele carregando as crianças no colo, servindo o exército... Lembro dos pais dele, eram muito boa gente... eles moraram no José Menino... Aquela famosa foto dele tomando CocaCola que se vê por aí é minha também. Há poucos anos atrás, ele comprou o meu acervo de imagens dele para o museu que ele vai construir, mas não temos mais uma relação de proximidade.

Já que o senhor citou a foto da Coca-Cola, existe uma história sobre ela. 0 senhor poderia nos esclarecer?

A foto é do Pelé com o Coutinho e o Dorval tomando coca-cola. Eu queria $R \$ 5$ mil pelo negativo, mas o Pelé pechinchou e me pagou $\mathrm{R} \$ 4$ mil. Daí, ele vendeu o negativo para Coca-Cola por uma fortuna. Fiquei sabendo que isso gerou um desentendimento entre eles (Pelé, Coutinho e Dorval), mas que, no fim, acabou tudo bem.

\section{Fora futebol, o senhor chegou a fotografar outros esportes?}

Claro, várias competições esportivas que aconteciam nos clubes aqui de Santos: no Saldanha, no Vasco... Natação, basquete, tudo que era esporte. Não tinha escolha; fazia de tudo com o maior prazer. Ah! Eu também fotografei os jogos do Jabaquara e da Portuguesa Santista, que são os outros times de futebol aqui da Cidade, viu? Não era só do Santos.

\section{O senhor jogava bola?}

Eu era um ótimo jogador de futebol, de verdade. Todo mundo falava que eu era ótimo, muito rápido, quando eu tinha uns 13 anos. .Mas eu não podia praticar porque eu precisei trabalhar; a dificuldade financeira da vida falou mais alto. E, quando 0 time jogava nos treinos, eu tirava sarro falando que eu era bem melhor, que eles eram fichinha perto de mim.

O senhor chegou a jogar com o time ou até com o próprio Pelé só por brincadeira, durante os treinos mesmo ou na casa de algum dos jogadores, por exemplo? 
De jeito nenhum. Nunca misturei trabalho com lazer. Minha função era fotografar. Não tinha nada disso de brincadeira; eu não podia jogar, tinha que trabalhar seriamente.

\section{Qual a melhor lembrança da época em que você fotografava o Santos Futebol} Clube?

Não sei te responder. Todas as vitórias do time são boas lembranças. Além disso, $\mathrm{O}$ Santos me prestou muitas homenagens...

De todos os lugares que o senhor conheceu com o Santos Futebol Clube, de qual mais gostou?

Eu gostei muito da Espanha, que é a terra dos meus pais. Gostei também de Portugal, da Itália... Sempre fui muito bem tratado em todos os lugares em que estive, não tenho reclamações, nunca me perdi, nunca fui assaltado, nunca passei apuros... Gostei de todos.

Todos os técnicos e jogadores te tratavam bem e respeitavam o seu trabalho? No geral, sim. Se tinha alguém antipático, eu era mais antipático ainda. Sempre tem aquele que gosta de aparecer e falar o que pode e o que não pode fazer, que gosta de opinar e se meter no que não sabe... Eu nem dava bola, fazia o meu trabalho e ia embora. Por outro lado, me dava muito bem com a maioria. Fiquei muito amigo do Pepe, do Zito, Orlando, de muitos deles.

De todas as fotos que o senhor tirou de Pelé, qual considera mais especial? Além da foto em que vestiu pela primeira vez a camiseta 10 do Santos, tem uma foto interessante que eu fiz lá na França do Pelé com a cabeça baixa e triste no vestiário, enquanto a multidão enlouquecida gritava o nome dele. $\mathrm{Na}$ ocasião, ele estava machucado e não podia jogar. Enquanto ele não se apresentou no gramado apenas para que todos pudessem ao menos vê-lo, o público não sossegou. Outra imagem bem interessante é dele conversando com o Garrincha, que era o craque do Botafogo. Os dois eram os melhores jogadores do Brasil e até do mundo.

\section{O senhor guarda alguma recordação do Rei do Futebol?}

Uma bola autografada dele, e algumas fotos, claro. 


\section{Qual foi o jogo mais marcante do Santos Futebol Clube?}

Todos sempre foram marcantes... Todos os jogos que o Santos ganhava, né? Eu gostava demais de assistir o Santos ganhar.

Fora o Pelé, qual dos jogadores era o melhor na sua opinião?

Todos os jogadores eram craques; todos eram bons. 
ANEXO E - Matérias sobre José Dias Herrera e sua produção.

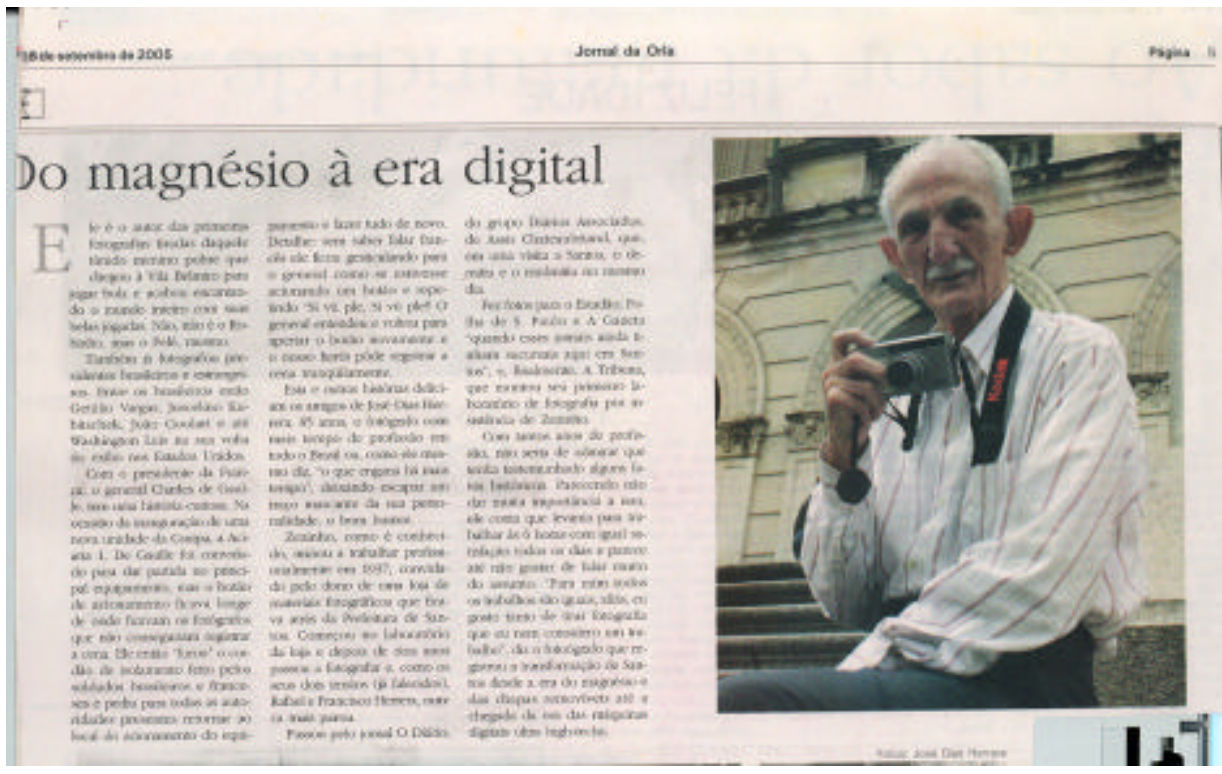

Sentos 16 de stal do 2006

JORNAUSMC

José Dias Herrera completa 85 anos de idade e 68 de fotografia

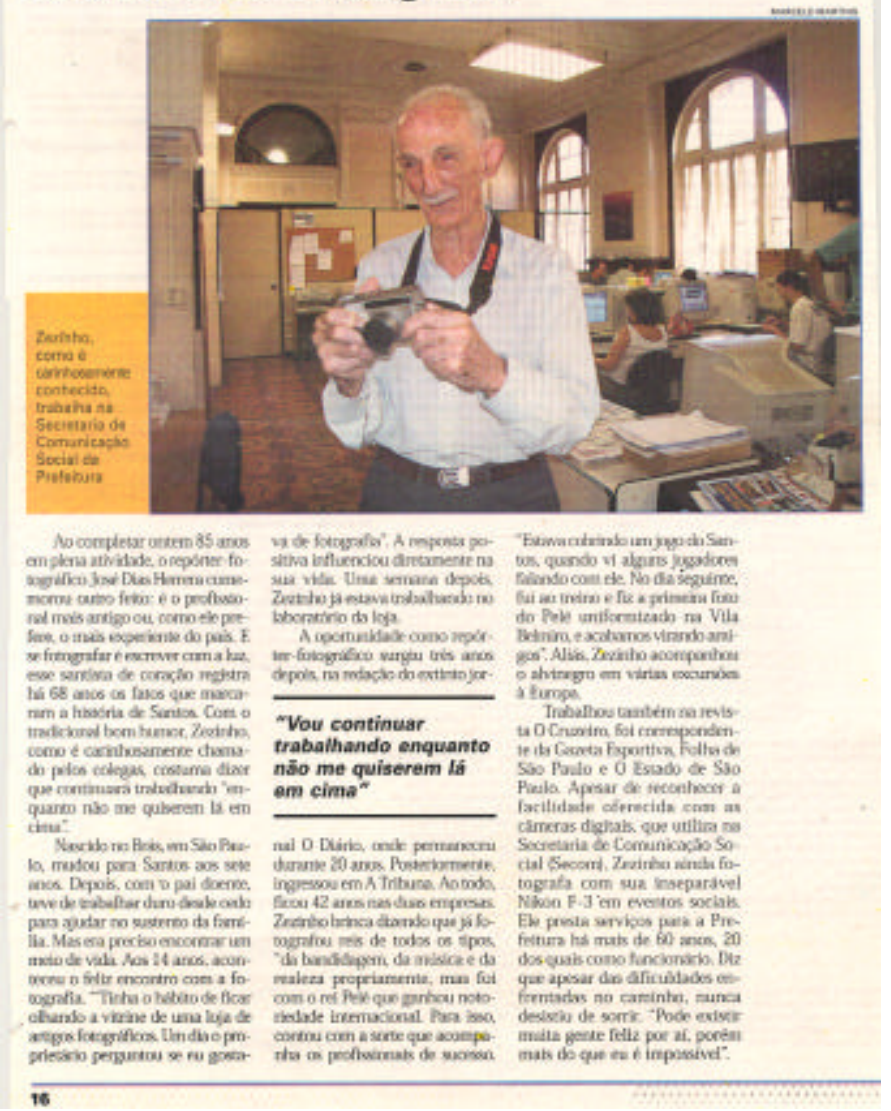



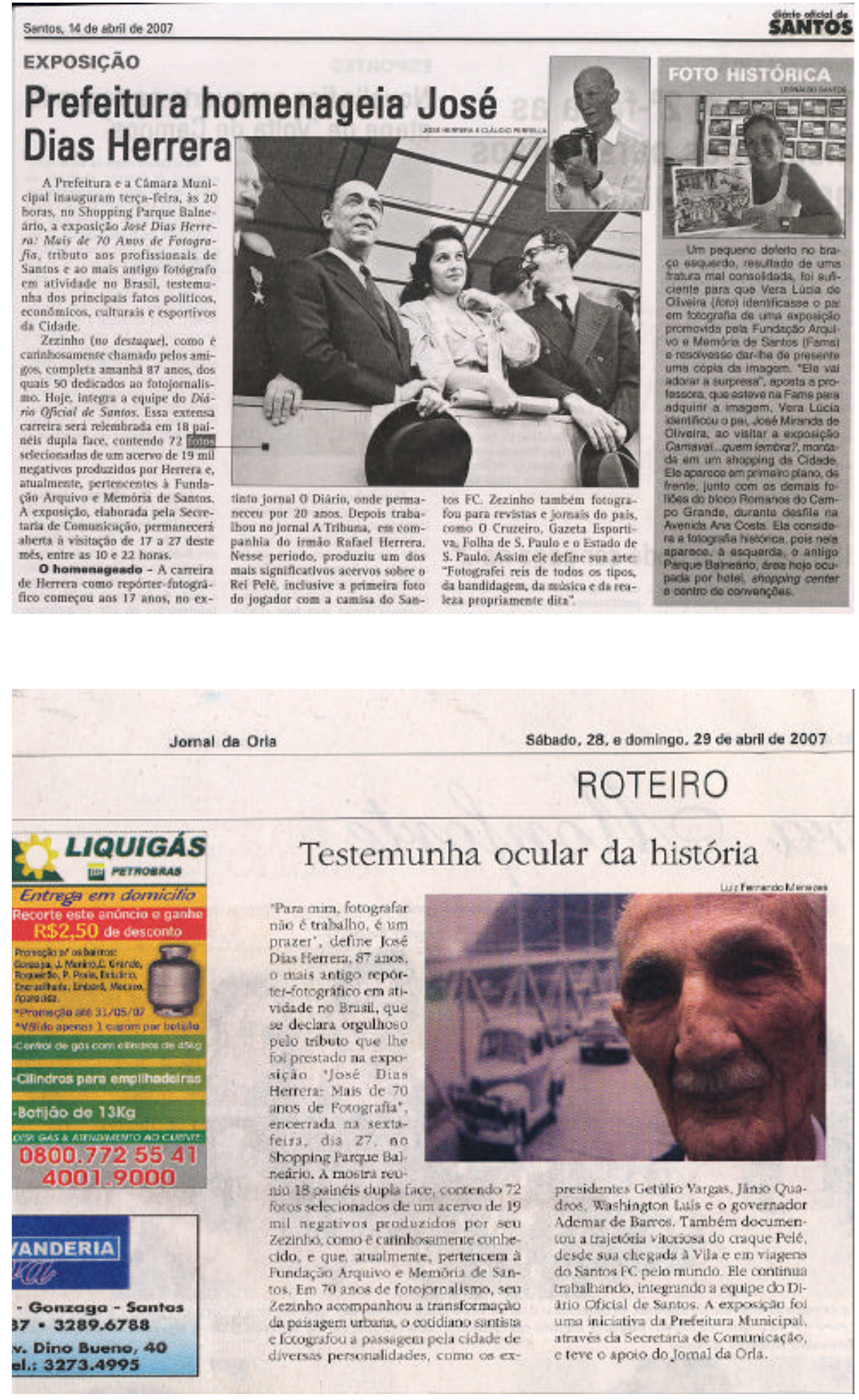
ANEXO G - Imagens da Exposição "José Herrera: mais de 70 anos de Fotografia".

O fotógrafo sendo alvo da imprensa na abertura da mostra, em 27 de abril de 2007, no shopping Parque Balneário.

Fotos: Antonio Vargas.
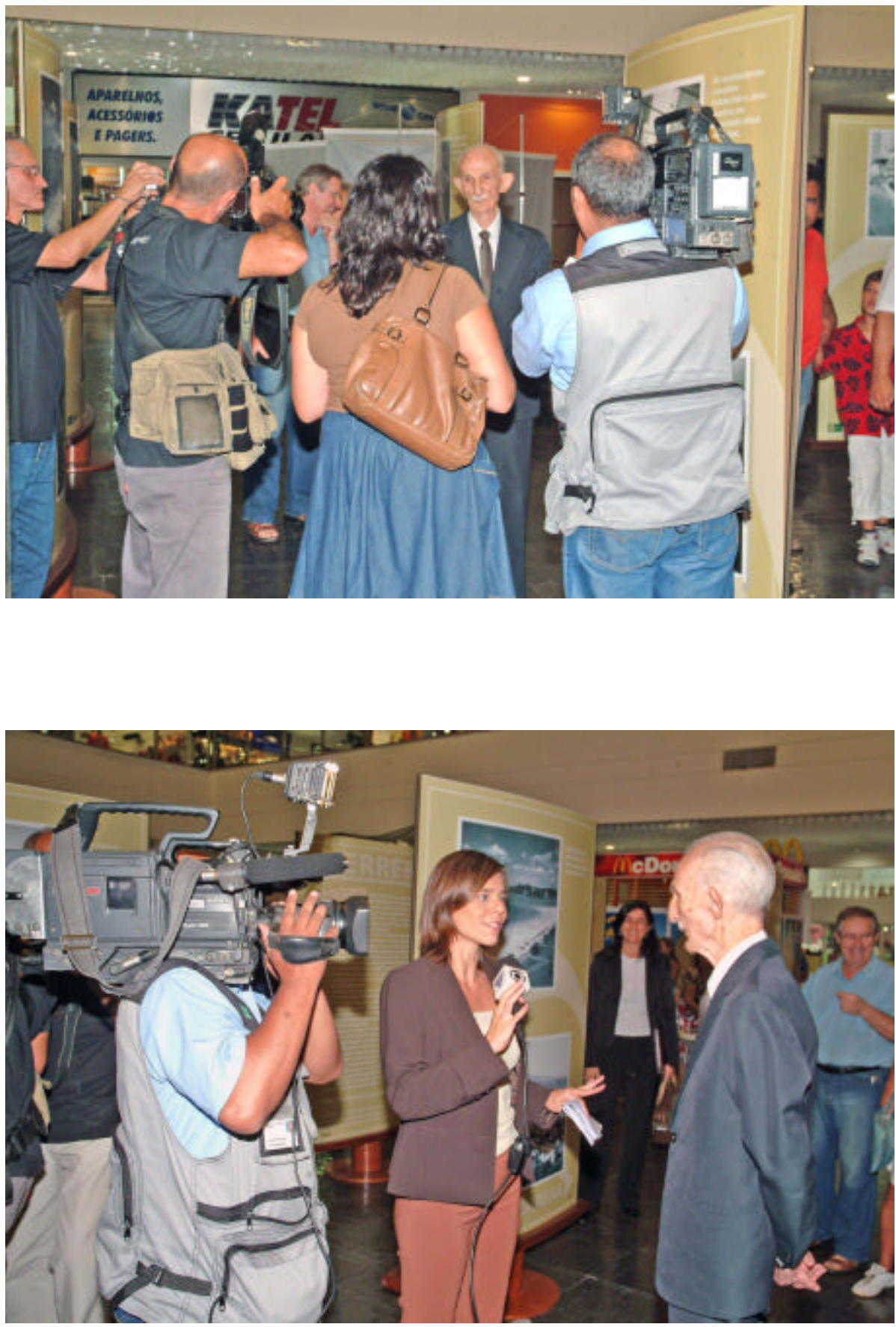
ANEXO H: José Herrera posa ao lado de outros fotógrafos durante a abertura da exposição em homenagem aos seus 70 anos de profissão, em 2007. Na imagem, da esquerda para direita: Antonio Vargas (Agência Folha de Notícias, TV Tupi, SBT e Prefeitura de Santos), Sérgio Furtado (Prefeitura de Santos), José Dias Herrera, Cândido Gonzalez (jornal A Tribuna, Sabesp e Prefeitura de Santos), Benedito Pontes (jornal A Tribuna e Prodesan), Luiz Fernando (Jornal da Orla) e Yasuo Kinjo (extinto jornal Cidade de Santos e Foto Boqueirão).

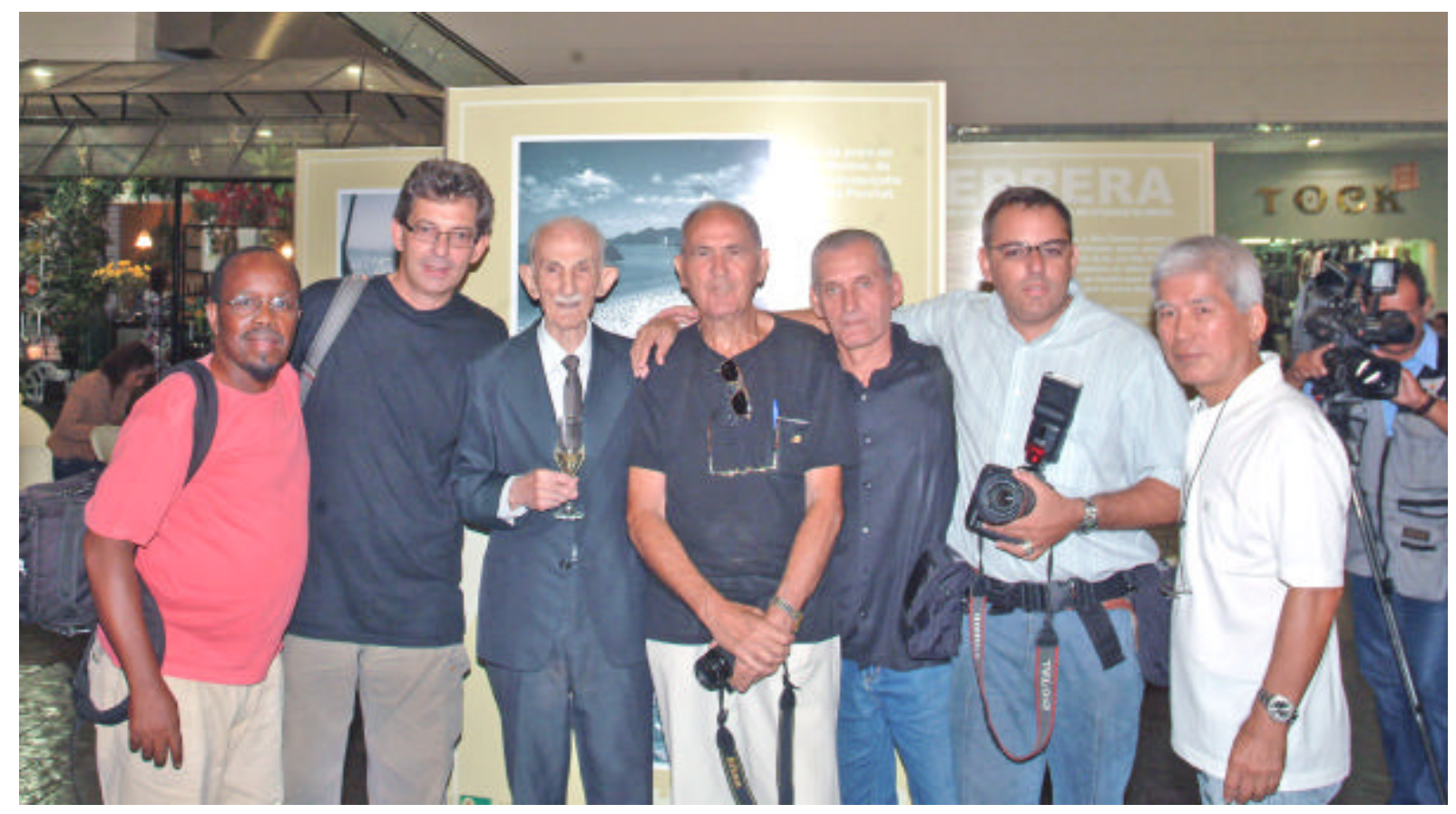


ANEXO I: O fotógrafo José Herrera posa com diversas câmeras fotográficas sobre a mesa da sala de jantar, em seu apartamento, no dia 15 de junho de 2007. A máquina mais alta é a famosa Rolleiflex e, ao seu lado direito, está uma Mamiya. Atrás da máquina que aparece à esquerda, com detalhes em vermelho, está a Nikon. Além disso, objetivas, flashes e tripés também aparecem na imagem.

Foto: Antonio Vargas.

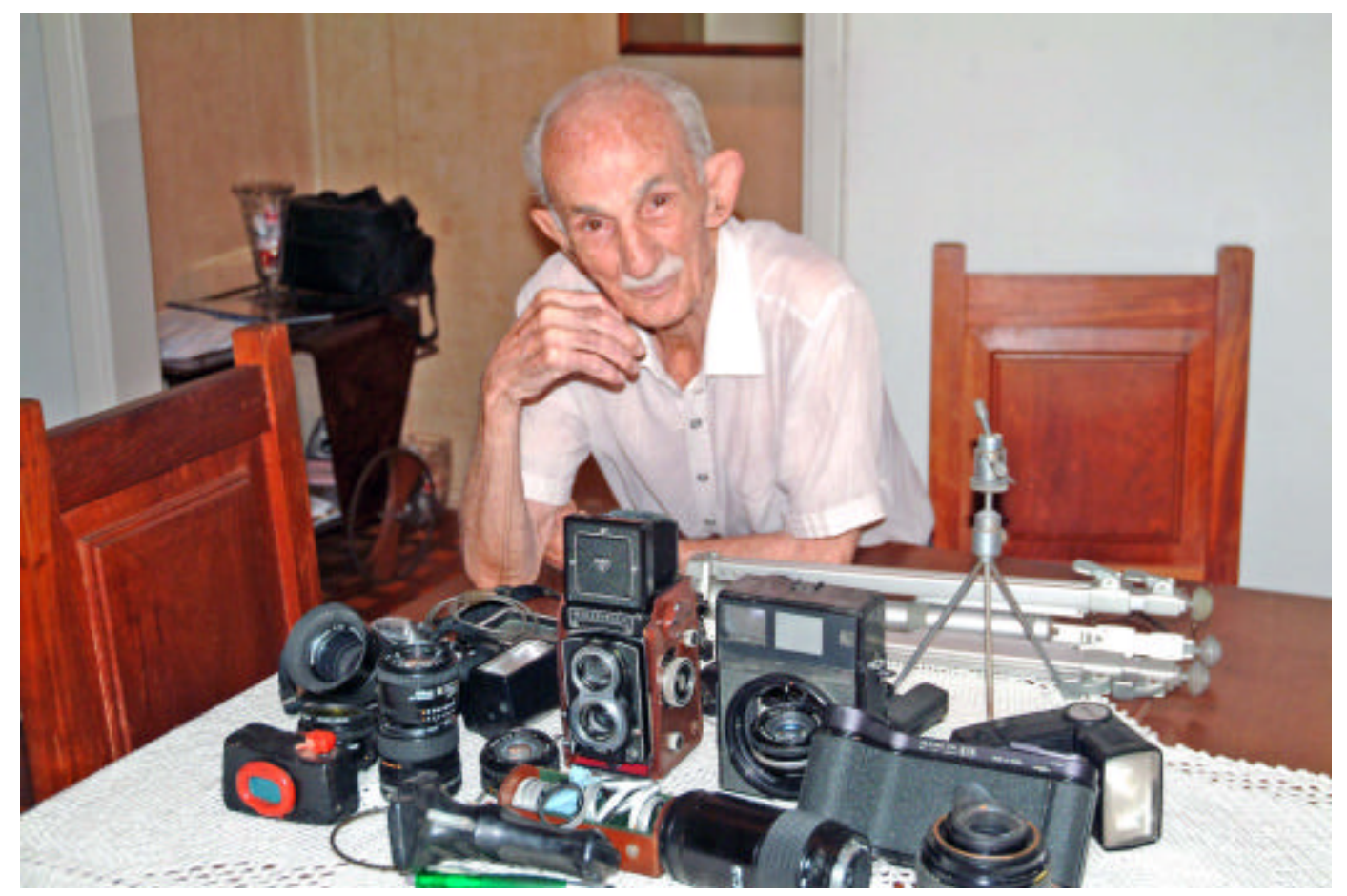


ANEXO J: José Herrera entregando ao então governador paulista, Mário Covas, a foto que havia tirado quando o mesmo era candidato a prefeito de Santos, em 1961. O encontro aconteceu durante o $13^{\circ}$ Seminário Internacional de Café de Santos, entre 15 e 19 de maio de 2000, no município de Guarujá. Álbum de família.

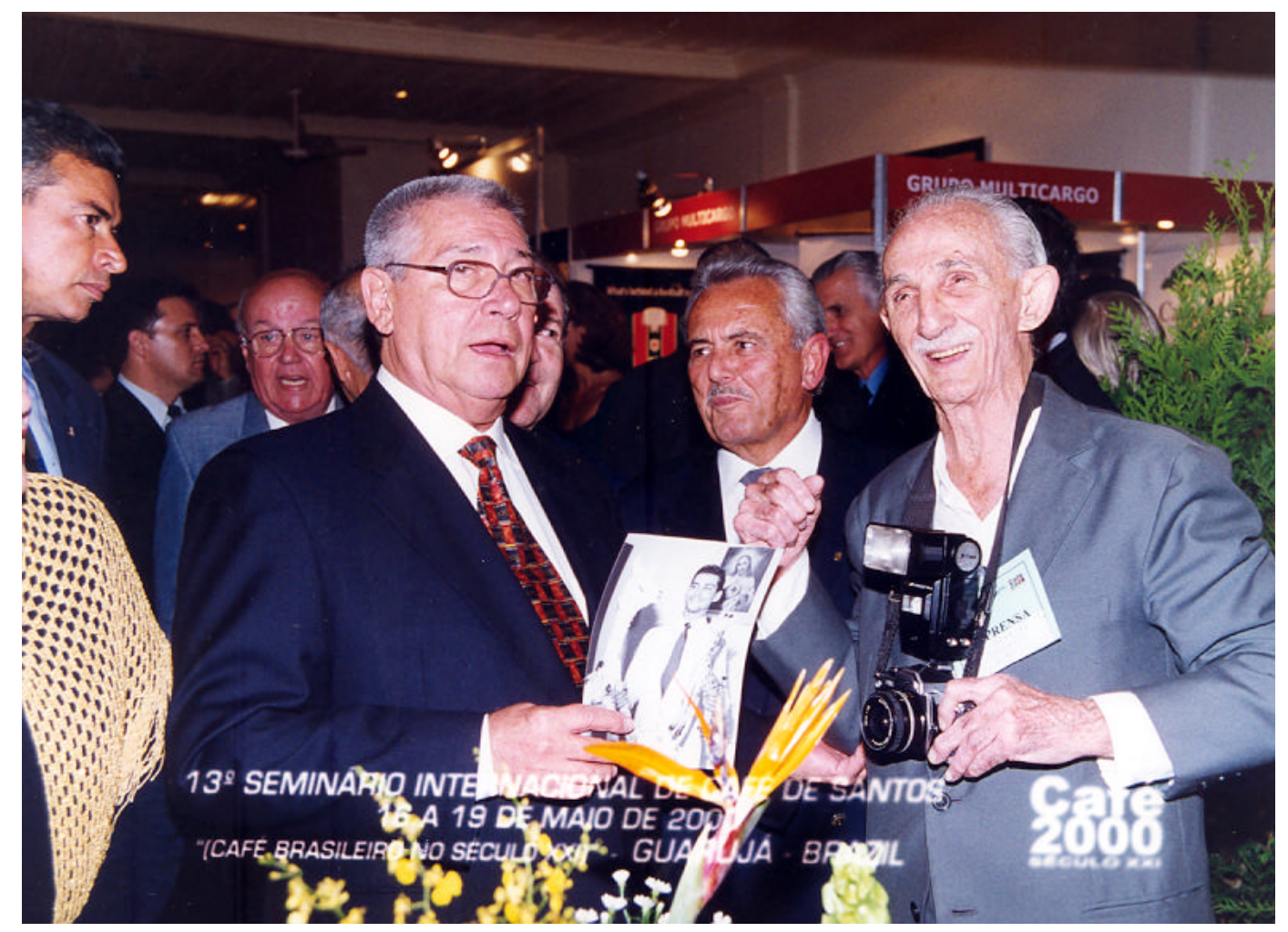


ANEXO L: José Herrera recebendo do então prefeito de Santos, Beto Mansur, uma placa alusiva aos seus 60 anos de profissão como fotógrafo, em 1997. Na imagem vemos também a chefe do Departamento de Comunicação Social da época e autora dessa dissertação, Wânia Seixas, e o ex-prefeito santista Osvaldo Justo.

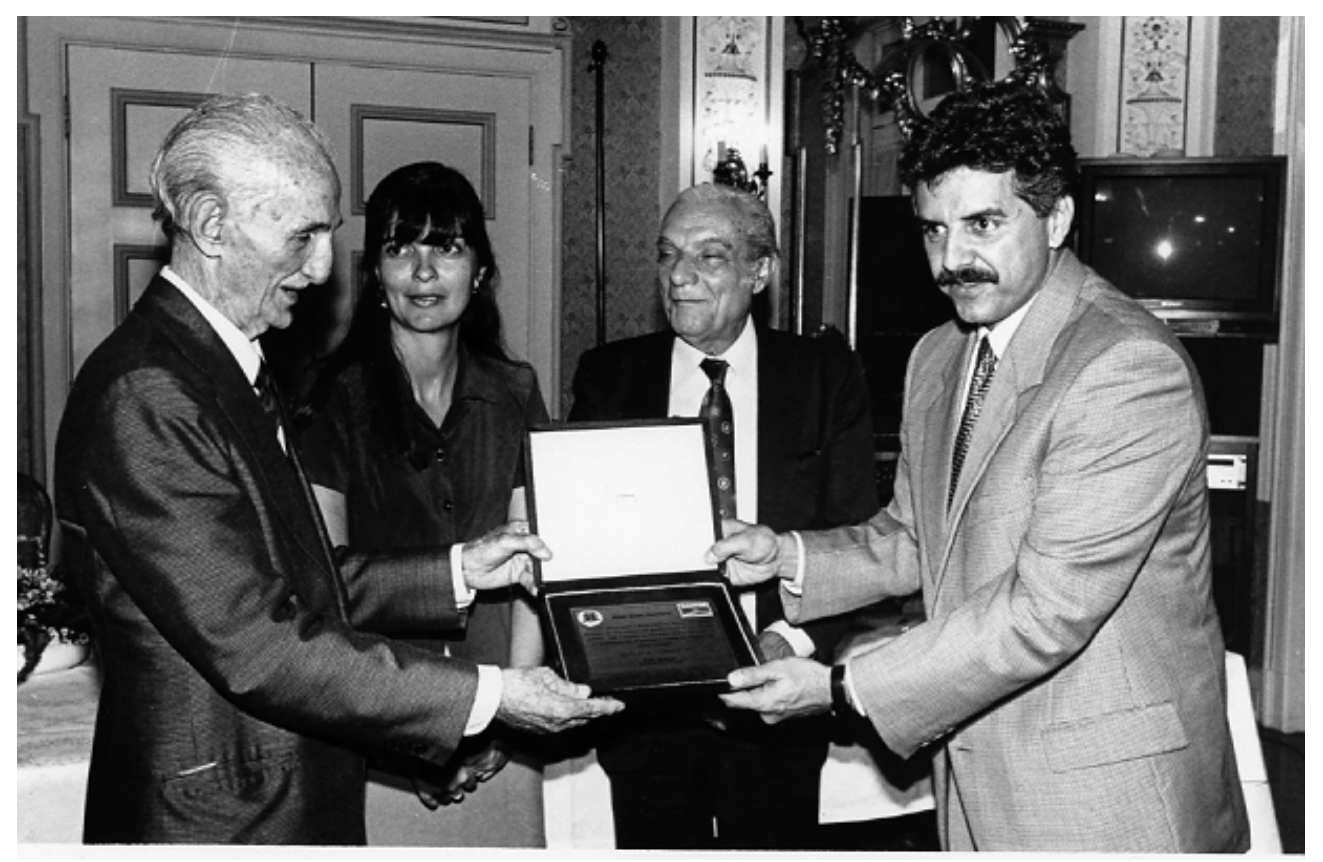

